\title{
RELATION OF HYDROGEOLOGIC CHARACTERISTICS TO DISTRIBUTION OF RADIOACTIVITY IN GROUND WATER, NEWARK BASIN, NEW JERSEY
}

By Zoltan Szabo, Ticie A. Taylor, Dorothy F. Payne, and Tamara Ivahnenko U.S. GEOLOGICAL SURVEY

Water-Resources Investigations Report 95-4136

Prepared in cooperation with the

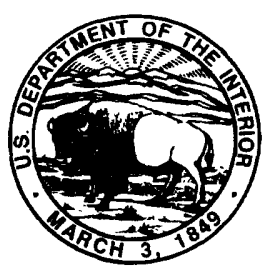
NEW JERSEY DEPARTMENT OF ENVIRONMENTAL PROTECTION

West Trenton, New Jersey 


\section{U.S. DEPARTMENT OF THE INTERIOR}

BRUCE BABBIT, Secretary

U.S. GEOLOGICAL SURVEY

Gordon P. Eaton, Director

For additional information write to:

District Chief

U.S. Geological Survey

Mountain View Office Park

810 Bear Tavern Road, Suite 206

West Trenton, NJ 08628
Copies of this report can be purchased from:

U.S. Geological Survey Branch of Information Services Box 25286

Denver, Colorado 80225-0286 


\section{CONTENTS}

Page

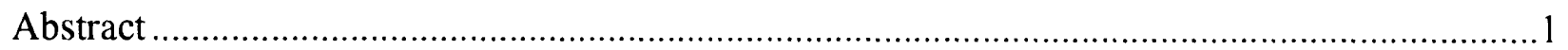

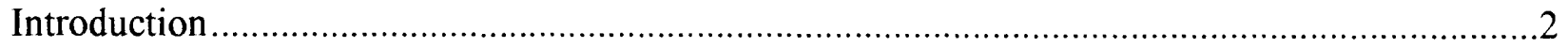

Purpose and scope

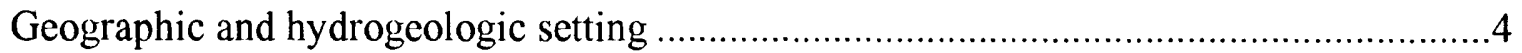

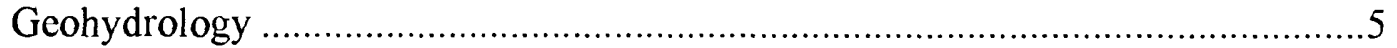

Uranium mineralization in the Newark Basin .................................................

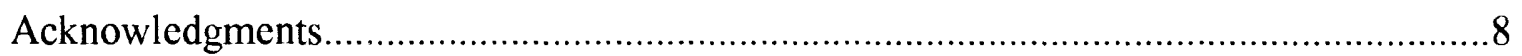

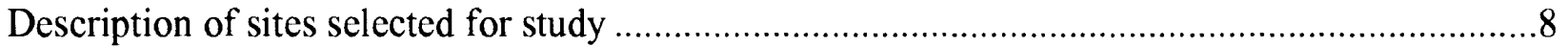

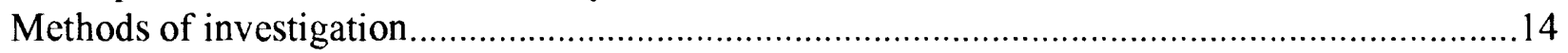

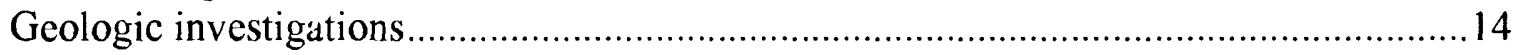

Well construction and development...............................................................14

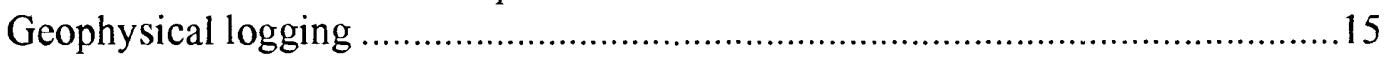

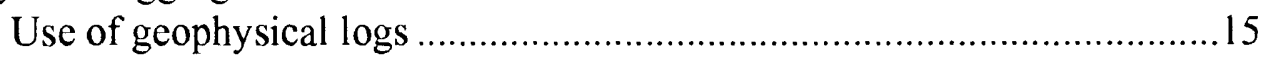

Stratigraphic correlations determined from geophysical logs ...................19

Determination of lithology and fracture density ..................................................21

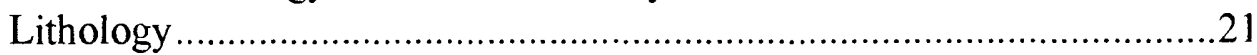

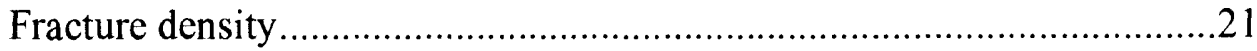

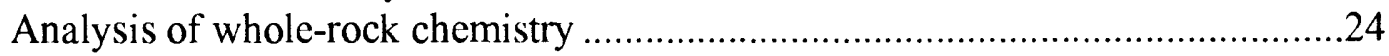

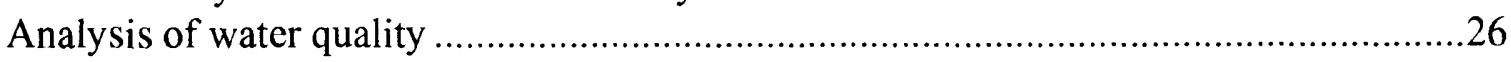

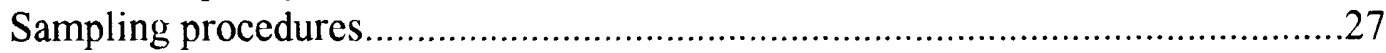

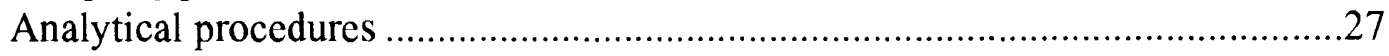

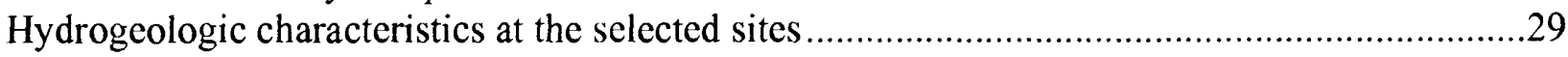

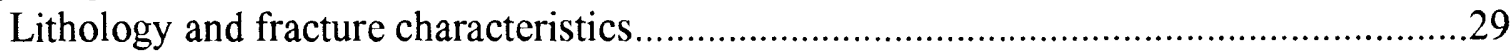

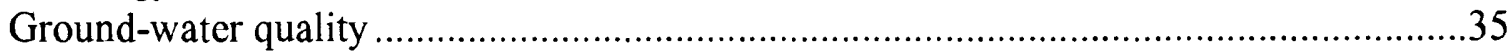

Relation of hydrogeologic characteristics to distribution of radioactivity in ground water ..........40

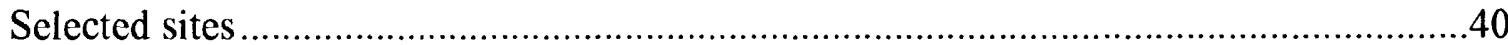

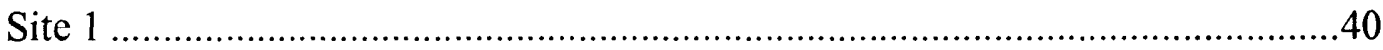

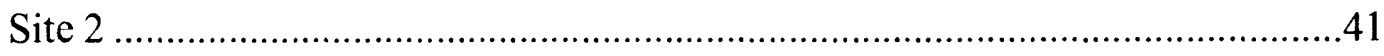

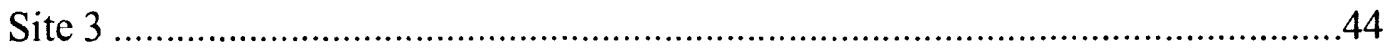

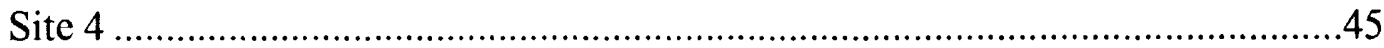

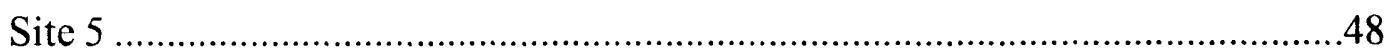

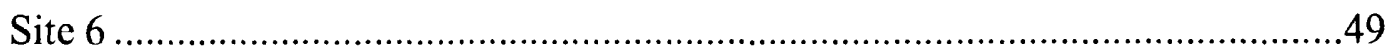

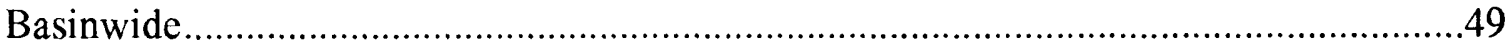

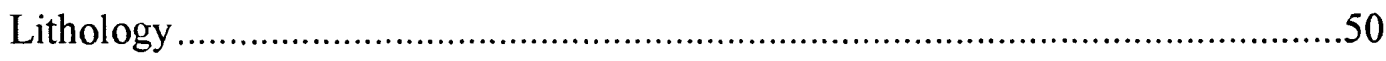

Continuity of radioactive lithologies within formations ............................50

Frequency of occurrence of radioactive lithologies within formations .....52

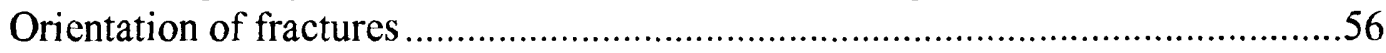

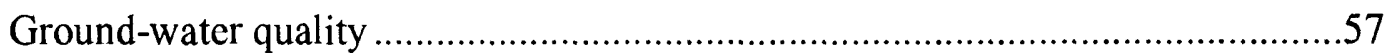

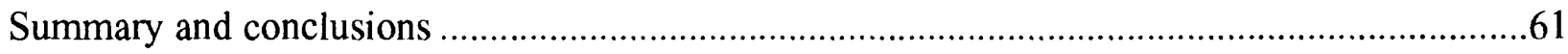

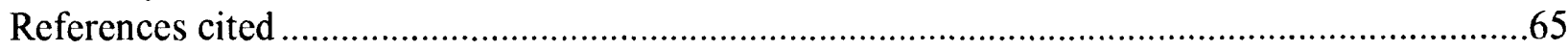

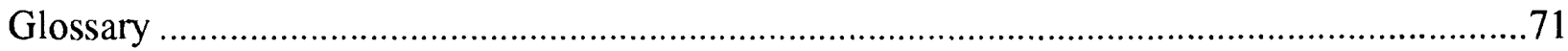




\section{CONTENTS--Continued}

Page

Appendix A. Records of selected wells and boreholes in the Newark Basin, New Jersey.

B-1. Major- and trace-element constituents of whole-rock samples from selected depths in three boreholes, south-central Newark Basin, New Jersey.....

B-2. Results of gamma-spectrometric analyses for uranium, thorium, potassium, and gross gamma, and hydrofluoric-acid digested whole-rock chemical analyses for uranium in rock samples from selected depths in three boreholes, south-central Newark Basin, New Jersey .....

C. Physical properties of, and concentrations of major ions, nutrients, trace elements, radioactive elements, and purgeable organic compounds in, water samples from boreholes or wells adjacent to boreholes, Newark Basin, New Jersey, 1985-91

D. Description of lithology, fracture characteristics, and ground-water quality at the selected sites, Newark Basin, New Jersey

\section{ILLUSTRATIONS}

Plate 1. Geologic logs and gamma logs, sites 1 and 2, south-central Newark Basin, New Jersey in pocket

2. Caliper log, fracture-density histogram, fracture-surface mineralogy, boreholeteleviewer $\log$, heat-pulse-flowmeter log, spontaneous-potential log, single-pointresistance log, and gamma log, sites 1 and 2, south-central Newark Basin, New Jersey in pocket

3. Geologic logs and gamma logs, sites 3 and 4, south-central Newark Basin, New Jersey in pocket

4. Caliper log, fracture-density histogram, fracture-surface mineralogy, boreholeteleviewer log, heat-pulse-flowmeter log, temperature log, spontaneouspotential log, single-point-resistance log, and gamma log, sites 3 and 4, south-central Newark Basin, New Jersey in pocket

5. Geologic logs and gamma logs, sites 5 and 6 , south-central and northeastern Newark Basin, New Jersey .... in pocket

6. Caliper log, fracture-density histogram, fracture-surface mineralogy, boreholeteleviewer log, spontaneous-potential log, single-point-resistance log, and gamma log, sites 5 and 6, south-central and northeastern Newark Basin, New Jersey in pocket

Figure 1. Map showing location of Newark Basin, New Jersey, and study sites 3

2. Map showing locations of six study sites and associated wells and boreholes, Newark Basin, New Jersey

3. Schematic diagram showing gamma-energy signatures of uranium-238, thorium-232, and potassium-40 showing energies of the major peaks identified by means of gamma-spectra logging. 


\section{ILLUSTRATIONS--Continued}

Page

Figure 4. Graph showing known energy peaks used to calibrate stationary gamma-

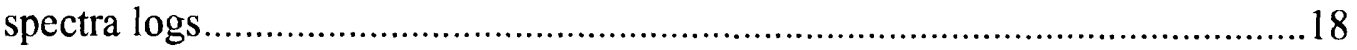

5. Schematic diagram showing example interpretation of fracture orientation from a borehole-televiewer image where magnetic declination is -12 degrees

6. Schematic diagram showing definitions of qualitative terms used to describe fracture density..... .23

7. Graphs showing relation of percentage of organic carbon to concentrations of (a) uranium and (b) vanadium in whole-rock samples from selected sites, Stockton Formation and lower part of the Passaic Formation, Newark Basin, New Jersey

8. Chemical composition of water from the Stockton Formation (sites 1 and 2) and the lower part of the Passaic Formation (sites 3, 4, 5, and 6), southcentral and northeastern Newark Basin, New Jersey

9. Gamma peaks, locations of fractures, intervals through which water is flowing, and stationary gamma spectra for the major gamma peak between 60 and 70 feet, well 21-358, site 2, Stockton Formation, south-central Newark Basin, New Jersey.....

10. Gamma log of the upper 175 feet, stationary gamma spectra from 18.75 , 102.5 , and 125.5 feet for the largest gamma peaks, and locations of fractures in the intervals at or near gamma peaks, well 19-250, site 4, Passaic Formation, south-central Newark Basin, New Jersey....

11. Gamma logs of, and possible correlation of radioactive strata between, wells along section B-B' in the direction of dip through the Passaic Formation, site 3, south-central Newark Basin, New Jersey

12. Gamma logs of, and possible correlation of radioactive strata between, wells along section A-A' in the direction of dip through the Stockton Formation, site 2, south-central Newark Basin, New Jersey.

13. Gamma logs from boreholes and wells along section C-D-E-F-G through the lower part of the Passaic Formation, site 4, south-central Newark Basin, New Jersey

14. Graph showing relation between gross alpha-particle activity and sum of radium-226, uranium-238, uranium-234, and uranium-235 activities as a function of dissolved-oxygen concentration in water samples from 10 wells and boreholes, south-central and northeastern Newark Basin, New Jersey, 1985-91

D-1. Gamma log of well 21-358, site 2, Stockton Formation, south-central Newark Basin, New Jersey, and stationary gamma spectra at the following depths, in feet: (A) 61.96, (B) 182.0, (C) 208.93, (D) 260.0, and (E) 272.51

D-2. Gamma log of well 21-159, site 3, Passaic Formation, south-central Newark Basin, New Jersey, and stationary gamma spectra at the following depths, in feet: (A) 133.96, (B) 140.53, and (C) 172.96 


\section{ILLUSTRATIONS--Continued}

Page

Figure D-3. Gamma log of well 19-251, site 4, Passaic Formation, south-central Newark Basin, New Jersey, and stationary gamma spectra at the following depths, in feet: (A) 33.18, (B) 48.0, (C) 72.81, (D) 172.98, and (E) 193.3.

D-4. Gamma log of well 19-250, site 4, Passaic Formation, south-central Newark Basin, New Jersey, and stationary gamma spectra at the following depths, in feet: (A) 18.75, (B) 102.5, (C) 125.5, (D) 345.0, and (E) 391.75.

D-5. Gamma log of well 23-1083, sitc 5, Passaic Formation, south-central Newark Basin, New Jersey, and stationary gamma spectra at the following depths, in feet: (A) 39.0 and (B) 54.0 .

\section{TABLES}

Table 1. Types of logs completed in boreholes, test wells, observation wells, and production wells, Newark Basin, New Jersey.

2. Distribution of number of fractures by orientation, depth, and rock type in cores from the Stockton Formation and lower part of the Passaic Formation, Newark Basin, New Jersey: (A) Number of fractures in cores from all rock types;

(B) Number of fractures in cores from 10 feet to 129 feet below land surface from all rock types by orientation; (C) Number of fractures in cores from all rock types, by orientation and depth below land surface; and (D) Number of fractures in cores by orientation and rock type

D-1. Characteristics of fractures identified on borehole televiewer log, and measured flow rates at selected depths, site 2, well 21-358, Stockton Formation, southcentral Newark Basin, New Jersey.

D-2. Characteristics of stationary gamma spectra measured at sites $2,3,4$, and 5 , Stockton Formation and lower part of the Passaic Formation, south-central Newark Basin, New Jersey

D-3. Characteristics of fractures identified on borehole televiewer log, site 3 , well 21-159, lower part of the Passaic Formation, south-central Newark Basin, New Jersey

D-4. Characteristics of fractures identified on borehole televiewer log, and measured flow rates at selected depths, site 4, well 19-251, lower part of the Passaic Formation, south-central Newark Basin, New Jersey .

D-5. Characteristics of fractures identified on borehole televiewer log, and measured flow rates at selected depths, site 4, well 19-250, lower part of the Passaic Formation, south-central Newark Basin, New Jersey

D-6. Characteristics of fractures identified on borehole televiewer log, site 5 , well 23-1083, lower part of the Passaic Formation, south-central Newark Basin, New Jersey 


\section{CONVERSION FACTORS, VERTICAL DATUM, AND ABBREVIATED WATER-QUALITY UNITS}

Multiply

inch (in.)

foot $(\mathrm{ft})$

mile (mi)

square mile $\left(\mathrm{mi}^{2}\right)$

square mile $\left(\mathrm{mi}^{2}\right)$

gallon (gal)

gallon (gal)

million gallons (Mgal)

cubic foot per second $\left(\mathrm{ft}^{\dot{3}} / \mathrm{s}\right)$

gallon per minute ( $\mathrm{gal} / \mathrm{min}$ )

million gallons per day (Mgal/d)

ounce, avoirdupois (oz)

pound, avoirdupois (lb)

degree Fahrenheit $\left({ }^{\circ} \mathrm{F}\right)$

\section{Temperature}

${ }^{\circ} \mathrm{C}=5 / 9 \times\left({ }^{\circ} \mathrm{F}-32\right)$

Specific capacity

Flow

0.02832

0.06308

0.04381

\section{Mass}

28.35

0.4536
To obtain

Length

25.4

0.3048

1.609

Area

259.0

2.590

Volume

3,785

3.785 liter

0.003785 cubic meter

cubic meter

millimeter

meter

kilometer

gram

kilogram

cubic meter per second

liter per second

cubic meter per second

degree Celsius $\left({ }^{\circ} \mathrm{C}\right)$

liter per second per meter

Sea level: In this report "sea level" refers to the National Geodetic Vertical Datum of 1929-- a geodetic datum derived from a general adjustment of the first-order level nets of the United States and Canada, formerly called Sea Level Datum of 1929.

Water-quality abbreviations:

$\mathrm{mg} / \mathrm{L} \quad$ - milligrams per liter

$\mu \mathrm{g} / \mathrm{L} \quad$ - micrograms per liter

$\mathrm{pCi} / \mathrm{L}$ - picocurie per liter

$\mu \mathrm{S} / \mathrm{cm}$ - microsiemens per centimeter at 25 degrees Celsius $\mu g / g$ - microgram per gram

ppm - parts per million

DO - dissolved oxygen

TOC - total organic carbon

VOC - volatile organic compound 


\title{
RELATION OF HYDROGEOLOGIC CHARACTERISTICS TO DISTRIBUTION OF RADIOACTIVITY IN GROUND WATER, NEWARK BASIN, NEW JERSEY
}

\author{
By Zoltan Szabo, Ticie A. Taylor, Dorothy F. Payne, and Tamara Ivahnenko
}

\begin{abstract}
The distribution of radioactivity in ground water in the Newark Basin is controlled by the lithology of the aquifer and the degree of contact between the water that flows through the fractured strata and the radioactive lithologic units. The primary water-bearing lithologic units of the Newark Basin that contain elevated levels of radioactivity are the arkosic sandstones of the Stockton Formation and the black mudstones of the lower part of the Passaic Formation. Lithologic and hydrogeologic characteristics of thesc rock aquifers that affect the spatial distribution of radionuclides in the water include the concentration of radioactive minerals in the strata; the continuity of radioactive strata; the orientation, depth, interconnectedness, and continuity of regional and local fracture patterns; and the geochemical environment, which affects radionuclide solubility.

The stratigraphic zones of uranium enrichment and the continuity of the radioactive strata differ between the Stockton Formation and the lower part of the Passaic Formation. Uranium enrichment in both formations, however, is identified in permeable sections of strata that have sharp contacts with, or that are cnclosed by, less permeable zones. In the Stockton Formation, basal conglomerates overlying fine-grained mudstones are the most radioactive lithology. In interbedded red and black mudstones of the lower part of the Passaic Formation, the uranium-rich zones are the black and white carbonate-rich siltstone and mudstone laminae overlying massive fine-grained mudstones. Most samples of the arkosic sandstones of the Stockton Formation tended to be slightly enriched in uranium relative to thorium, whereas all samples of the black mudstones of the lower part of the Passaic Formation were heavily enriched in uranium with respect to thorium, with a maximum concentration of uranium of 6,200 parts per million (ppm).

Spatial orientation of radioactive zones is controlled by the depositional environment of the host lithology. Radioactive strata in the arkosic sandstones of the Stockton Formation, which is deltaic or fluvial/deltaic in origin, are stratigraphically discontinuous and nonplanar. In contrast, the radioactive lacustrine black mudstones of the lower part of the Passaic Formation are laterally continuous and planar.

Geophysical logs of borcholes indicate that the number and depths of probable waterbearing fractures are greater in the arkoses of the Stockton Formation and red mudstones of the lower part of the Passaic Formation than in the interbedded red and black mudstones of the lower part of the Passaic Formation, despite the fact that fracture-density counts in cores indicate that black mudstones are more highly fractured than the other rock types. The total number of fractures is greater and bedding-plane fractures are generally more common in the lower part of the Passaic Formation than in the Stockton Formation. Fractures in the Stockton Formation form a well-connected network consisting of both bedding-plane and several sets of high-angle fractures present on a regional scale. The large-scale continuity of interconnected bedding-plane fractures
\end{abstract}


and high-angle regional fractures may be partly responsible for the higher yields observed for wells in the Stockton Formation than for wells in the Passaic Formation and may facilitate migration of dissolved radionuclides far from their source. The well-connected fracture network may increase the likelihood that circulating water comes in contact with radioactive strata. Water in the black mudstones of the lower part of the Passaic Formation may also contain high levels of radioactivity, primarily as a result of the high frequency of radioactive strata and of fracturing, rather than the presence of a well-connected regional fracture system.

Ground-water chemistry is dominated by the calcium cation and the bicarbonate anion, both derived from abundant secondary calcite in the fractures. The concentrations of uranium and radium in water that comes into contact with radioactive rock are controlled by the water chemistry. Uranium is the dominant alpha emitter in the oxidizing waters in the red mudstones of the Passaic Formation, whereas radium-226 $\left({ }^{226} \mathrm{Ra}\right)$ is the dominant alpha emitter in the suboxic (reducing) water in the black mudstones of the lower part of the Passaic Formation. Because the lithology of the Stockton Formation and, in places, the lower part of the Passaic Formation varies greatly, wells can intercept multiple fracture zones that can contain oxic or suboxic waters, thereby resulting in the presence of both uranium and radium in detectable quantities in the same water sample.

\section{INTRODUCTION}

Naturally occurring radionuclides present as trace elements in most rocks and soils are potential sources of contaminants in ground-water supplies. Elevated levels of radionuclides of radon, radium, and uranium dissolved in water are known to be carcinogenic. A recent estimate indicates that as many as 40,000 lung-cancer fatalities per 70 years can be attributed to radon in public drinking-water supplies in the United States (Cothern, 1987). This figure may be significantly higher if self-supplied (domestic) well water is taken into account (Zapecza and Szabo, 1988). In addition, consumption of water containing elevated concentrations of radium or uranium can lead to accumulation of radioisotopes of these elcments in human bone tissue, producing bone and head-sinus cancers. Therefore, the U.S. Environmental Protection Agency (USEPA) has issued final or proposed maximum contaminant levels (MCL's) for many radioactive constituents in drinking water (U.S. Environmental Protection Agency, 1991; 1994).

Elevated levels of naturally occurring radionuclides in ground water are associated with uranium enrichment in black mudstone and arkosic sandstone in the Newark Basin, New Jersey (Zapecza and Szabo, 1987; Szabo and Zapecza, 1987). The Newark Basin (fig. 1) coincides with the Piedmont Physiographic Province and comprises a 10-county area of approximately 2,000 square miles. It accounts for one-fifth of the State's land area, as well as about two-thirds of its population. More than 100 million gallons per day of ground water is withdrawn from Newark Basin rocks in New Jersey to serve more than 5 million people.

In 1985, the U.S. Geological Survey (USGS), in cooperation with the New Jersey Department of Environmental Protection (NJDEP), began to study the distribution of naturally occurring radionuclides in ground water in the Newark Basin. In addition to describing radionuclide distribution, the study was conducted to determine the relation of hydrogeologic characteristics

including lithology, fracture characteristics, and ground-water quality to the distribution of radio- 


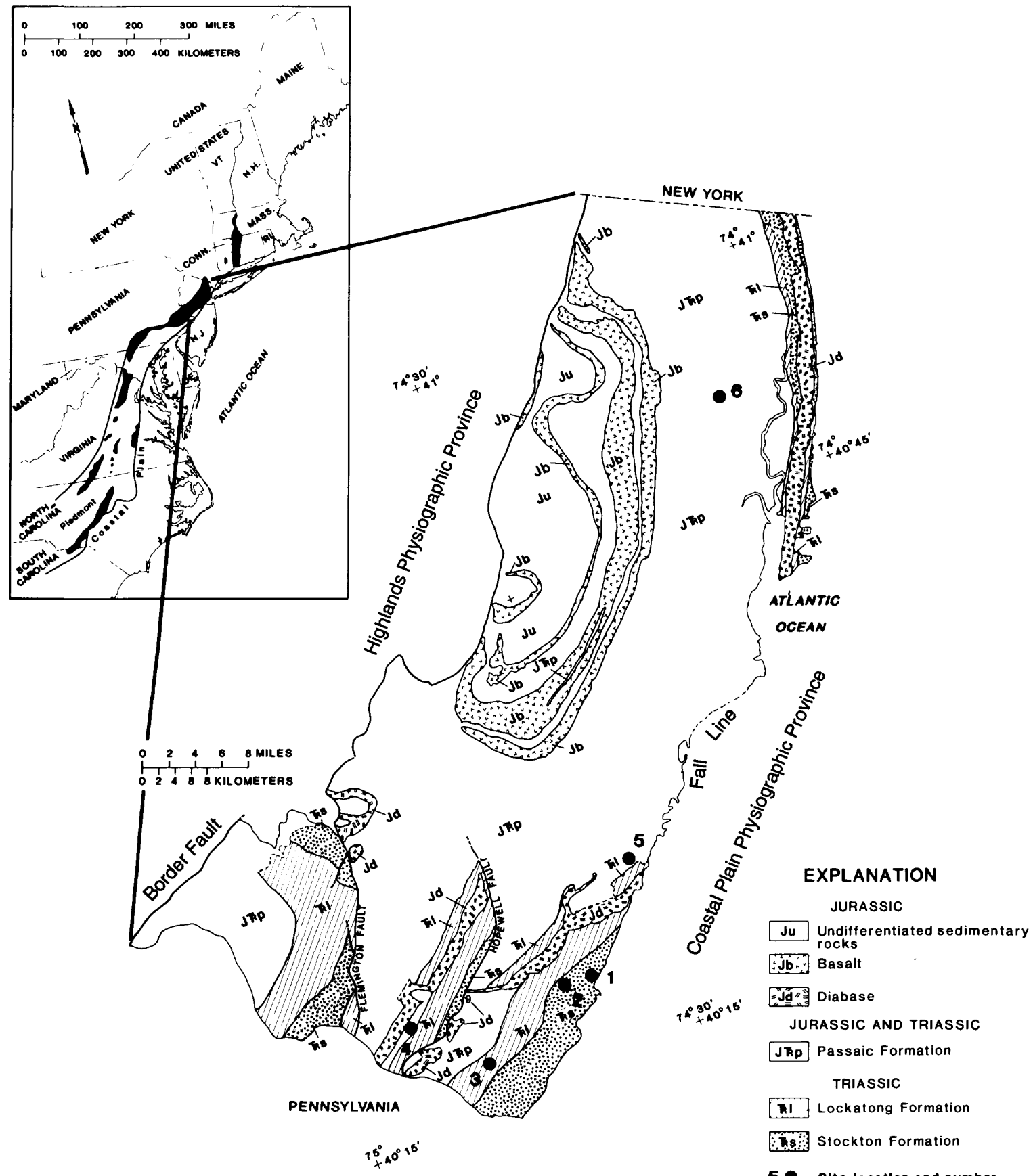

Figure 1. Location of Newark Basin, New Jersey, and study sites. (Location map modified from Froelich and Olsen (1985); geologic map modified from Lyttle and Epstein (1987) and TurnerPeterson and others (1985). Shaded areas in location map represent exposed basins of the Newark Supergroup in the Eastern United States.) 
activity in water in the fractured sedimentary-rock aquifers. The approach of this latter part of the study was to characterize the lithology and mineralogy of radioactive zones, characterize the radionuclide distribution in the aquifers in both water and rock, determine the distribution of waterbearing fractures and their relation to radioactive strata, and evaluate the nature of the groundwater geochemical environment (especially with regard to oxidation state) as defined by waterquality samples and fracture-coating mineralogy. These data were used to determine whether hydrologic and geochemical processes vary with lithology and the effect these processes have on the mobility of radionuclides in the water in the Newark Basin.

\section{Purpose and Scope}

This report presents the results of an observation-well-drilling and borehole-geophysicallogging program conducted at six study sites in the Newark Basin during 1985-91 designed to determine the relation of hydrogeologic characteristics of the rock aquifers to the distribution of dissolved radioactivity by characterizing the radionuclide content of the rock in various lithologies and that of circulating water, and by investigating the fracture characteristics in these lithologies. Geologic, geophysical, and geochemical data collected during the study and presented in this report include results of macroscopic examination of core samples, borehole geophysical analyses (such as gamma logs, gamma-spectral logs, caliper logs, borehole televiewer logs, spontaneous-potential logs, single-point-resistance logs, and heat-pulse flowmeter logs), chemical and gamma-spectral analyses of whole-rock samples to identify and chemically characterize radioactive zones in subsurface rocks, and water-quality analyses of samples from observation wells and boreholes. The water samples collected from the study sites were analyzed for concentrations of gross alpha- and beta-particle activity, ${ }^{222} \mathrm{Rn}$ (radon-222), ${ }^{226} \mathrm{Ra}$ (radium-226) and ${ }^{228} \mathrm{Ra}$ (radium228), uranium (and in some samples, that of various uranium isotopes), major ions, and trace elements; DO (dissolved-oxygen) concentration, specific conductance, $\mathrm{pH}$, and water temperature were determined in the field. The data are evaluated site by site and differences between data collected from each geologic formation or rock type are interpreted from a regional perspective.

\section{Geographic and Hydrogeologic Setting}

The Newark Basin is one of several sedimentary fault-block basins formed during the Mesozoic Era that crop out in a belt from Nova Scotia to North Carolina (fig. 1). It coincides with the Piedmont Physiographic Province in New Jersey (Fenneman, 1938). The Newark Basin is unconformably bounded on the southeastern edge by Cretaceous sediments of the Coastal Plain Physiographic Province (the Fall Line) and on the northwestern edge by the Border Fault, which separates it from Precambrian and Paleozoic crystalline rocks of the Highlands Physiographic Province (Fenneman, 1938).

The Triassic sedimentary sequence of the Newark Basin is composed of beds of terrigenous clastic sedimentary rocks deposited in the continental rift basin. The beds strike east-northeast and dip to the northwest about 5 to $30^{\circ}$. Episodes of volcanic and intrusive activity in the Jurassic Period, interspersed with clastic depositional sequences, complete the Newark Supergroup. The Jurassic sequence (fig. 1) is not discussed in this report. The postdepositional period was characterized by uplift at the southeastern margin combined with downfaulting. at the northwestern margin, which resulted in the characteristic northwest tilt of the beds (Van Houten, 1969). 
The mineralogy and petrology of the rocks of the Stockton, Lockatong, and "Brunswick Group" Formations are discussed in detail by Van Houten $(1962,1965)$. (The pre-Watchungvolcanic-event Brunswick Group sedimentary rocks were renamed the "Passaic Formation" by Olsen (1980) when he redefined the Newark Supergroup in the Newark Basin, New Jersey.) The drilling and sampling sites are located in the Triassic sedimentary units of the lower section of the Newark Supergroup: the Stockton Formation and the Passaic Formation (fig. 1).

The Stockton Formation is the oldest of the Triassic sedimentary formations and is composed of alluvial and fluvial arkosic sandstone, arkosic conglomerate, and red mudstone and

siltstone. It is well-cemented and its lithology varies over small vertical distances. The Stockton Formation unconformably overlies crystalline basement rocks, forms the basal beds of the Newark Supergroup, and grades upward and laterally into the Lockatong Formation. The Lockatong Formation is characterized by cyclic lenticular lacustrine sequences. The dominant lithologies are gray to black mudstones and siltstones (Van Houten, 1962) that generally are wellcemented. As the Lockatong Formation grades upward into the Passaic Formation, gray and black mudstone and siltstone units become thinner and less abundant; red mudstones and siltstones become the predominant lithology (Olsen, 1980). The basal section of the Passaic Formation contains interbedded red, maroon, brown, gray, and black mudstones and siltstones. The middle and upper part of the Passaic Formation is composed of red clastic mudstones and siltstones and fine-grained muddy sandstones, representing mudflat facies. The mudstones and siltstones can be characterized as a calcareous palcosol (Suchecki and others, 1988). The Passaic Formation is moderately well- to well-cemented with fissile to massive bedding.

\section{Geohydrology}

Water in the formations of the Newark Basin primarily is stored in, and transmitted through, a complex network of interconnected openings along joints, fractures, faults, beddingplane partings, and, to a much smaller extent, interstitial pore spaces and solution channels. Because the characteristics of subsurface fracture systems are unknown, characterization of ground-water flow is difficult. Regional fracture patterns can be projected from surficial and borehole fracture traces; this information can be used to characterize fracture properties which controls movement of water in the rock aquifer. Fracture and joint sets vary in their ability to store and transmit water; therefore, the aquifer may exhibit anisotropic hydrologic properties (Michalski, 1990).

Wells completed in the Newark Basin are open boreholes. Below the surface casing, which is typically installed through the regolith (near-surface weathering zone) into competent bedrock, the well is an open hole that intercepts multiple fractured zones, many of which yield water. Geophysical logging of these open holes can help define the frequency, orientation, and water-yielding capacity of these fractures. Hydraulic properties of the formations depend primarily on the fracture patterns. Rima (1955) studied the hydraulic properties of the Lockatong and "Brunswick" (Passaic) Formations by using flowmeter logs, caliper logs, and spontancous-potential and resistance logs to characterize the geohydrology and identify productive fracture zones. The hydraulic properties of the Stockton Formation, including porosity, specific yield, coefficient of permeability, transmissivity, and storage coefficient, are described by Rima and others (1962). 
Fracture patterns vary with lithology but can be classified into two major types: nearvertical fracture patterns (of somewhat varying strike) and bedding-plane or low-angle fracture patterns (Rima and others, 1962; Kasabach, 1966; Vecchioli and others, 1969; and Houghton, 1990). The abundance and spacing of open fractures vary with rock type and proximity to land surface. Bedding-plane fracture sets are abundant in all the fissile lithologies and are thought to be the dominant water-bearing zones (Michalski, 1990). In lithologies that tend to be massive, such as poorly bedded sandstones, mudstones, and siltstones, near-vertical fracture patterns predominate. Near-vertical fractures in the Stockton Formation in southeastern Pennsylvania have been categorized into regional sets (Rima and others, 1962). The most common trend of these fractures is perpendicular to the bedding strike. Another set of fractures trends nearly parallel to the bedding strike, and a third set trends northwest at about 50 degrees from the bedding strike. Several near-vertical fracture sets in the Lockatong and Passaic Formations also have been categorized. Two sets of these near-vertical fractures were observed in the Passaic Formation--one trending almost parallel to the bedding strike and the other trending almost perpendicular to the bedding strike (Vecchioli and others, 1969). A third set of near-vertical fractures generally found in both the Lockatong and Passaic Formations trends about 15 to 50 degrees counterclockwise from the bedding-plane strike (Houghton, 1990).

High-angle fractures and bedding-plane fractures distributed throughout the stratigraphic section can form a system of water-bearing zones parallel to bedding with intervening "leaky aquitards" (Michalski, 1990). The fissile, high-yielding zones, bounded on either side by massive confining units, are characterized by high porosity and storage, a moderate degree of fracture interconnectedness, and low to moderatc permeability and conductivity. The confining units are characterized by low storage capacity and high vertical conductivity along fracture planes (Houghton, 1990). Drawdown is greater in wells in the massive lithologies than in wells in the fissile lithologies.

The thinly bedded mudstones, found most commonly in the Passaic Formation, are fissile and are a preferred medium for bedding-plane fracture patterns. Because of pervasive interconnected fracturing, the hydraulic properties of fissile mudstone units can be similar to those of unconsolidated matcrial (Houghton, 1990). These fissile units are not common in the Lockatong Formation. Some massive units--especially the arkoses of the Stockton Formation--can contain abundant and closely spaced vertical fractures, whereas lithologies in the Stockton Formation that would be expected to be fissile--even siltstones and mudstones--can contain few and distantly spaced fractures. Metamorphosed zones of mudstone and siltstone near diabase intrusions may show little water-bearing potential due to the effects of hydrothermal processes, such as additional cementation and recrystallization of clay minerals into an interlocking massive fabric resistant to fracturing. The effects of hydrothermal processes are particularly common in the lower part of the Passaic Formation in Hunterdon County (Kasabach, 1966).

The effect of weathering on various lithologies may also be responsible for variations in the water-bearing potential of the formations. In the regolith of the coarse-grained arkosic rocks of the Stockton Formation, weathering removes some of the cement that seals fractures and closes pore spaces; therefore, open fractures and pore spaces are abundant, resulting in grcat capacity for storage and movement of water. The fine-grained rocks of the Lockatong and Passaic Formations, however, weather to fine clay. Therefore, flow through fractures in the regolith can be 
restricted by clogging with clay, despite the greater abundance of open, uncemented fractures in this zone than in the regolith overlying the Stockton Formation (Kasabach, 1966).

Yields from wells vary with formation and lithology. Well yields depend on fracture density, orientation, and interconnectedness. Wells in the Stockton Formation have the greatest yields of the three formations, which can be attributed to permeability of fractures near the surface, the thick regolith zone, and to the overall abundance of bedding-plane fractures. The high permeability and porosity of coarse-grained beds of well-sorted, loosely cemented material also contribute to the water-bearing potential of the Stockton Formation (Rima and others, 1962). The relative scarcity of open horizontal fractures, the thin regolith zone, and the low waterbearing potential of near-surface fractures (due to clay filling) coupled with the presence of densely cemented rocks generally result in lower yiclds in the Lockatong and Passaic Formations than in the Stockton Formation. Yields of wells in the Passaic Formation, especially where red mudstone, siltstone, or sandstone are present, are significantly greater than those of wells in the Lockatong Formation as a result of the greater abundance of fissile mudstone units, the thick regolith zone, and less dense cementation in the Passaic Formation than in the Lockatong Formation.

\section{Uranium Mineralization in the Newark Basin}

Recent studies have addressed the stratigraphic distribution of uranium and associated radionuclides in Newark Basin sedimentary rocks. Bell (1983) compiled a list of radioactive mineral occurrences in the Newark Basin. Airborne radiometric data and results of indoor airborne radon testing are presented as part of a report that defines geologic factors that affect the presence of uranium in sedimentary rocks in the Newark Basin (Muessig and Houghton, 1988).

Several investigators define the diagenetic mechanisms by which uranium mineralization occurs in the Newark Basin. Turner-Peterson (1977) proposes the lacustrine-humate postdepositional genetic model for enrichment of uranium in the Stockton Formation and the syngenetic depositional model for enrichment of uranium in the organic black muds comprising the Lockatong Formation. Turner-Peterson (1980) integrated these models into one conceptual model by applying the facies concept to uranium mineralization in the Newark Basin. Turner-Peterson and others (1985) defined diagenetic geochemical processes (sorption onto humate followed by reduction) that controlled fixation of uranium in the Stockton Formation and in black mudstones of the Lockatong Formation. The presence of anomalous concentrations of radioactivity in black mudstones of the lower part of the Passaic Formation reported by Zapecza and Szabo (1987) is interpreted to be consistent with the conceptual model of Turner-Peterson (1980).

The aqueous geochemistry and distribution of dissolved radionuclides in water in the Newark Basin have been examined recently. Zapecza and Szabo (1987) document elevated concentrations of radioactivity in water in the Stockton and Lockatong Formations and the lower part of the Passaic Formation. Szabo and Zapecza (1987) determined the relation of uranium to ${ }^{226} \mathrm{Ra}$ (inverse correlation) and to other chemical constituents (especially iron) in ground water in the Newark Basin. 


\section{Acknowledaments}

The authors thank Sonny Saroya (New Jersey Department of Environmental Protection) for his assistance in well-sampling design, and Mike Flite (New Jersey Department of Environmental Protection) for his aid in designing the fracture-density analysis. We thank Dr. Bahman Parsa, Patricia Gardner, Kirk Nemeth, and Nancy Stanley (New Jersey Bureau of Environmental Laboratories Radiation Protection Laboratory) for performing the gross alpha- and beta-particle activity, radium and radon analyses. We thank Karl Muessig (New Jersey Department of Environmental Protection), Scott Keys (Keys, Inc.), and Charles Brown (U.S. Geological Survey) for helpful comments. We thank Gregory Simpson (U.S. Geological Survey) for assembling the plates. Last, we thank George Glahn and Michael McKay (Princeton University), David W. Stem (Hunterdon County Engineer), Steve Baldwin and John Stark (Johnson and Johnson Company), Bob Siery (Borough of Wallington), West Amwell Fire Company, and Bristol Myers Company for allowing access to their properties.

\section{DESCRIPTION OF SITES SELECTED FOR STUDY}

Drilling sites for the study were chosen on the basis of information previously gathered from gamma logs of wells and from information on the distribution of ground-water samples containing elevated concentrations of naturally occurring radionuclides (Zapecza and Szabo, 1987). The eleven boreholes are located at six sites in the Newark Basin in north-central New Jersey (fig. 1). The six sites are located in Plainsboro Township and North Brunswick Township in Middlesex County, Princeton Township and Hopewell Township in Mercer County, West Amwell Township in Hunterdon County, and Borough of Wallington in Bergen County.

Site 1 is located in the outcrop of the Stockton Formation and appears to be about $2.8 \mathrm{mi}$, along dip, from the established contact with the Lockatong Formation as mapped by Lyttle and Epstein (1987). Borehole 23-932 at site 1 is about 0.7 mi east of the Millstone River in Plainsboro Township, Middlesex County, at an elevation of $60 \mathrm{ft}$ (fig. 2). It is drilled to a depth of $120 \mathrm{ft}$ in the middle to upper part of the Stockton Formation, about $1 \mathrm{mi}$ south of the conformable contact with the Lockatong Formation, and about 0.5 mi north of the Fall Line (fig. 1). Two observation wells, 23-800 and 23-801, completed to about the same depth as borehole 23-932, are located approximately $200 \mathrm{ft}$ from the borehole (site 1, fig. 2).

Bee Brook, a small tributary to Devil's Brook (fig. 2), is the surface-water body nearest to site 1. Devil's Brook empties into the Millstone River. Topography near the site is broad and flat with only slight relief near the headwaters of Bee Brook. The tributary reach of Bee Brook is a losing stream as a result of pumping in the area; however, the upstream and downstream reaches are gaining (Lewis and Spitz, 1987). High soil percolation rates (mean rate for all sites is $11.3 \mathrm{in} / \mathrm{hr}$ ) have been measured (Lewis and Spitz, 1987). The rocks that crop out at site 1 are predominantly a pink, orange, and yellow-gray fine-grained sandstone with interbedded massive pale-red siltstones. These sedimentary rocks probably are deltaic or fluvial in origin, as is proposed for the Stockton Formation (Van Houten, 1969; Olsen, 1980). The strata are extensively fractured in outcrop. They strike N.65E. and dip 8 degrees NW. (Lewis and Spitz, 1987; Hugh Houghton, New Jersey Geological Survey, oral commun., 1987). The siltstone and mudstone bedrock weathers to a red, clayey soil that is common throughout the Newark Basin. 
Many industrial and observation wells are present in the vicinity of site 1, as listed by Lewis and Spitz (1987). Water in the area is used primarily for industrial, domestic, and fireprotection purposes. Maximum well yiclds in the area are $100 \mathrm{gal} / \mathrm{min}$ (Lewis and Spitz, 1987). Water quality in the Stockton Formation in the area of site 1 has been adversely affected by contamination with trichloroethylene (TCE), and concentrations of manganese and iron commonly exceed USEPA's secondary drinking-water regulations (Lewis and Spitz, 1987).

The observation well (21-358), production well (21-383), and borehole (21-359) in the Stockton Formation at site 2 are located in Princeton Borough, Mercer County (fig. 2). The site is near the Rocky Hill Ridge in the Piedmont Physiographic Province. The wells and borehole penetrate the upper part of the Stockton Formation. Site 2 is $0.5 \mathrm{mi}$ from the established conformable contact with the Lockatong Formation in the dip direction and is stratigraphically higher than site 1 (as illustrated in fig. 1, which is based on geologic mapping by Lyttle and Epstein (1987)). The nearest surface-water bodies to site 2 are the man-made Delaware-Raritan Canal and Carnegie Lake. The only natural surface-water body is the Millstone River, which lies southeast of the site.

The strike of the Stockton Formation at site 2 is about N.65E., and the strata dip about 8 NW. (Hugh Houghton, New Jersey Geological Survey, written commun., 1987). The outcrop at the site is composed of fine- to coarse-grained either gray or yellow to orange sandstones and conglomerates, dark gray to pale orange siltstones, and some pale-red to brownish-gray mudstones. These rocks are densely fractured and well-weathered in the exposed outcrops, and commonly are heavily stained by limonite. The siltstones and mudstones weather to a dense, yellow-orange or reddish clay-rich soil. The regolith is about $19 \mathrm{ft}$ thick.

Yields of wells in the Stockton Formation in the Princeton Borough area typically are high. Measured discharges range from 1 to $30 \mathrm{gal} / \mathrm{min}$ for domestic wells and from 25 to $905 \mathrm{gal} / \mathrm{min}$ for industrial and public supply wells. Water use in the area is mainly for public supply and industrial uses, though domestic, irrigation, and fire-protection uses abound. Water quality is generally good; however, TCE, 1,1,1-trichloroethane, and 1,1-dichlorethylene were detected in a nearby public supply well and several nearby industrial wells. Therefore, water in observation well 21-358 was sampled for voiatile organic compounds (VOC's).

Site 3 is located in Hopewell Township, Mercer County, near the Rocky Hill Ridge (fig. 2). The borehole (2l-290) is at an elevation of $120 \mathrm{ft}$ above sea level. Houghton (1990) maps the strata here as the lower part of the Passaic Formation and shows a conformable contact with the underlying Lockatong Formation $0.5 \mathrm{mi}$ south of site 3 . The basinwide map of Lyttle and Epstein (1987) shows this area as part of the Lockatong Formation (fig. 1); in this report, the strata at this site are referred to as part of the Passaic Formation based on the recent work of Houghton (1990).

The outcrop of the lower part of the Passaic Formation in the Hopewell Township area is dominated by a grayish-red-brown to grayish-purple massive mudstone that varies little. The mudstone weathers to a thick, clayey, red soil. Weathering is shallow; the average thickness of the regolith is about $11 \mathrm{ft}$. The surface-water body nearest to site 3 is Woolsey Brook, which empties into Jacobs Creek (fig. 2), which ultimately drains into the Delaware River (fig. 1). 


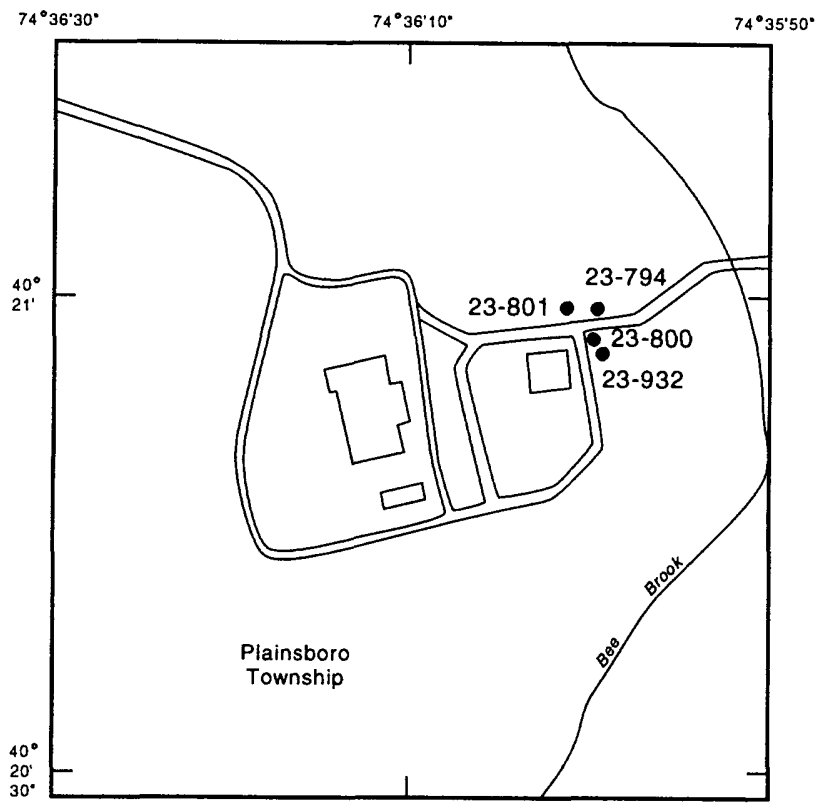

\section{EXPLANATION}

Gamma logs along lines $A-A^{\prime}, B-B^{\prime}$, and $C-D-E$ and $F-G$ are shown in figures

11,12 , and 13 , respectively

\section{$A-A^{\prime} \quad$ LINE OF SECTION}

23-932 - Location and number of well or borehole

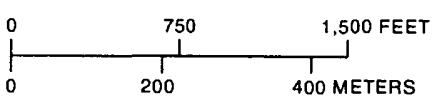

Site 1

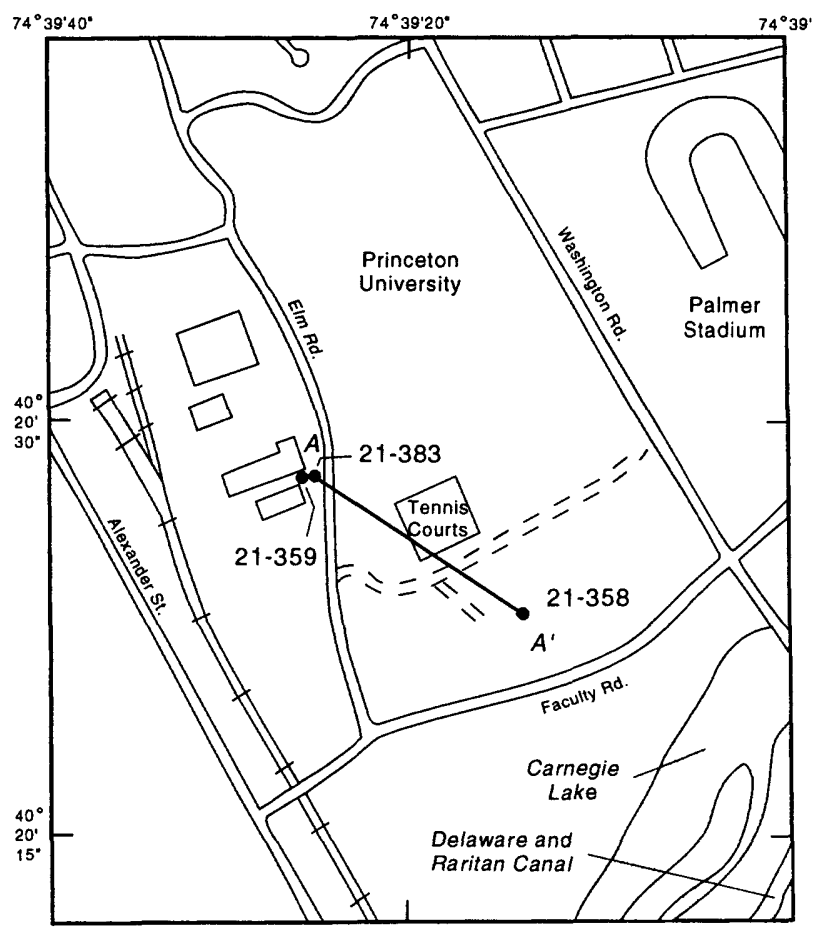

Site 2

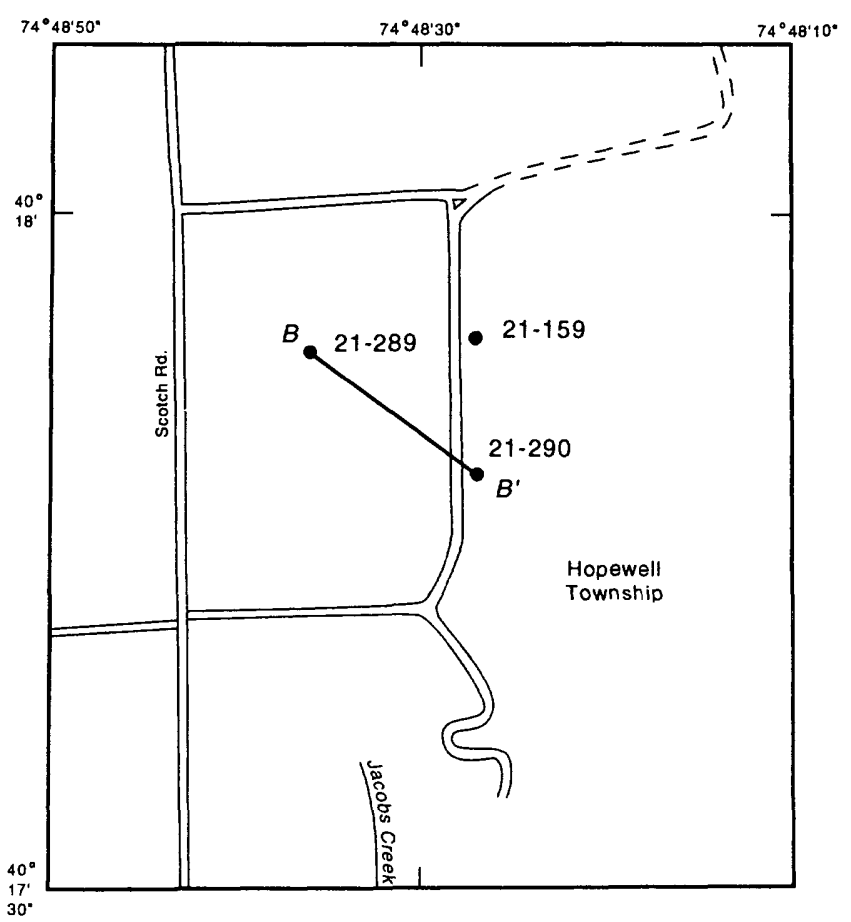

Site 3

Figure 2. Locations of six study sites and associated wells and boreholes, Newark Basin, New Jersey. 


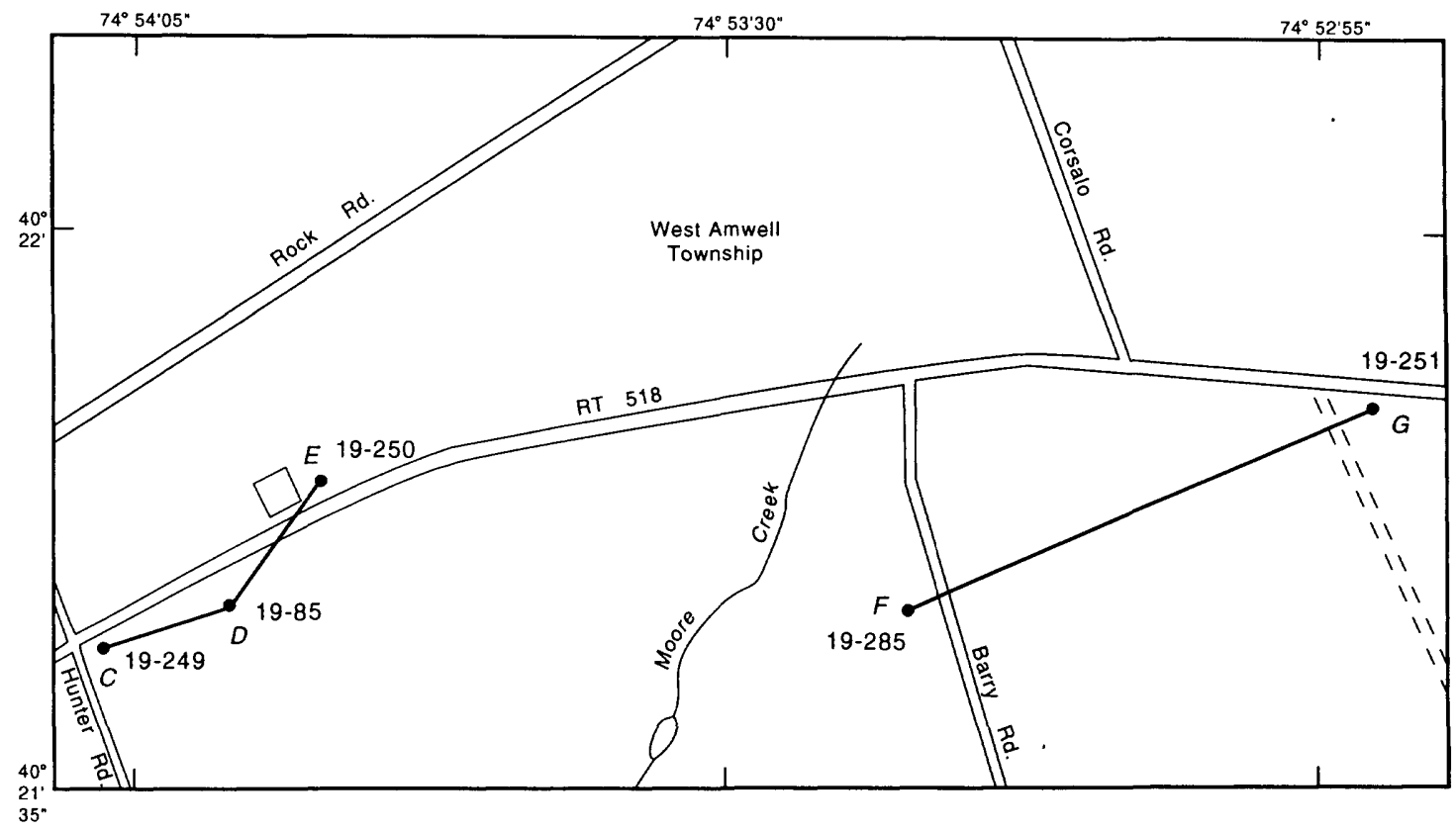

Site 4

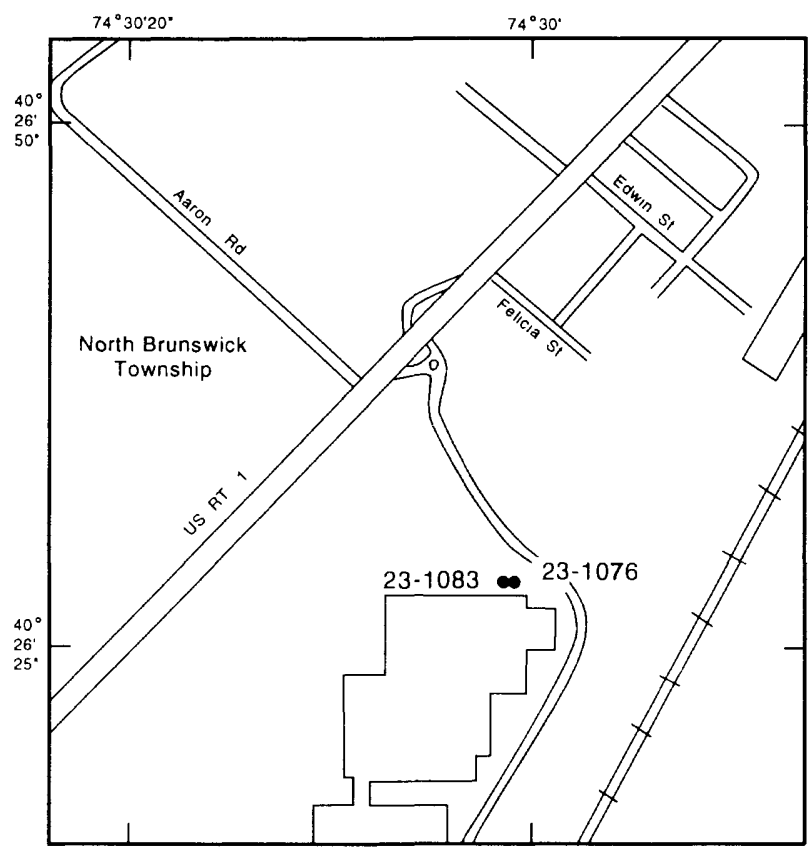

Site 5

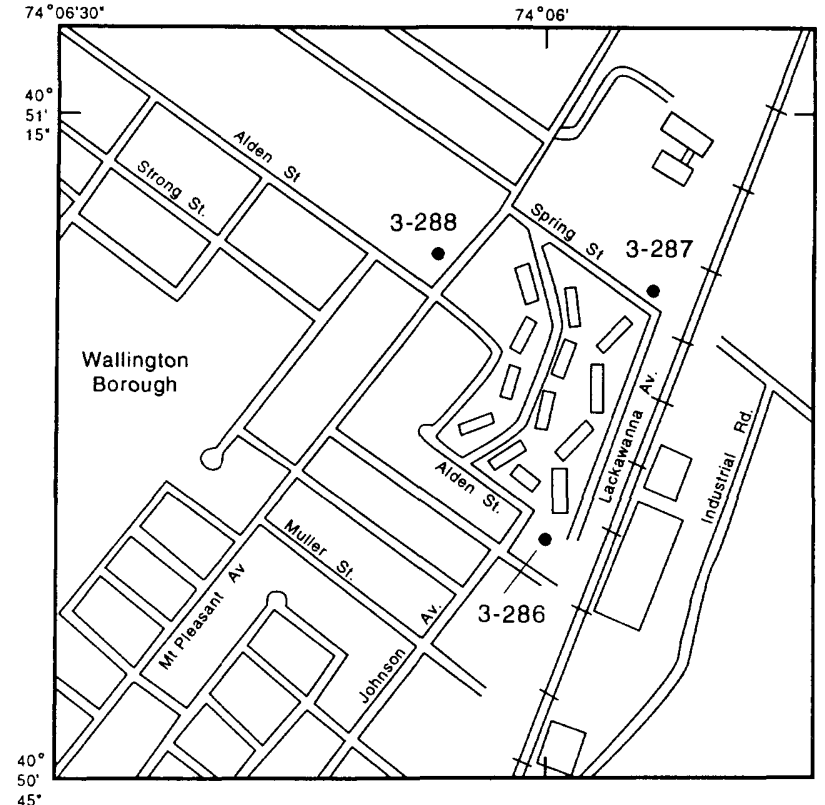

Site 6

Figure 2. Locations of six study sites and associated wells and boreholes, Newark Basin, New Jersey--Continued. 
In the area of site 3, ground water is used primarily for irrigation, industrial, and domestic purposes. Two unused irrigation wells (21-159 and 21-289) are located at this site (fig. 2). Yields of wells in the Passaic Formation in Hopewell Township (excluding observation wells) range from 1.5 to $65 \mathrm{gal} / \mathrm{min}$; specific capacities range from 0.03 to $1.25(\mathrm{gal} / \mathrm{min}) / \mathrm{ft}$ of drawdown. Because the yields of these wells are low to moderate, water supply is a concern. During sampling, well 21-159 was pumped at $9 \mathrm{gal} / \mathrm{min}$ for 4 hours with little drawdown. Water quality in the Passaic Formation in this area is good, although hardness is a common water-quality problem.

Site 4 is located in West Amwell Township, Hunterdon County (fig. 2), on the Schooley Peneplain. Three wells (19-249, 19-250, and 19-251) were drilled into the lower part of the Passaic Formation. The site is about 0.25 mi south of a Jurassic diabase intrusion (fig. 1), northwest of Lambertville, New Jersey. Site 4 is $0.5 \mathrm{mi}$ north of the established gradational contact with the underlying Lockatong Formation (fig. 1). Site 4 appears to be closer along dip than site 5 to the established contact of the Passaic Formation (determined on the basis of gcologic map data by Lyttle and Epstein (1987)). Thus site 4 is stratigraphically lower than site 5 .

The dominant lithologies of the Passaic Formation that crop out in the area are grayishred-purple and black to light-gray mudstones, and dark-gray to light-gray silty mudstones. Intercalated calcareous siltstones are interbedded in the silty mudstones in places. The strata into which the wells were drilled strike N.65E. and dip about 20NW. in the surface outcrop (Hugh Houghton, New Jersey Geological Survey, written commun., 1989). Virtually no soil has been developed on either the densely cemented mudstone or the adjacent diabase in this area. Competent bedrock, which commonly is found 1 to $2 \mathrm{ft}$ below land surface, was encountered at a depth of about $6 \mathrm{ft}$ or less at two of the three well locations. The soil that has developed is a dense, plastic, poorly permeable red or blue-gray clay that typically clogs the fractures; therefore, infiltration capacity and storage capacity of the weathered soil and regolith zone is minimal.

Local sources of surface water are the Lambertville Water Company Swan Creek Reservoir and the headwaters of Moore Creek. Because the rock is poorly fractured and nonporous, swampy conditions exist above and adjacent to the nearby Jurassic intrusion and throughout much of the area surrounding site 4 . The diabase intrusion forms a ridge that acts as a local surfacewater divide about $420 \mathrm{ft}$ above sea level. All surface water in the area, however, ultimately drains into the Delaware River.

Water use in the area is primarily for domestic, irrigation, and stock-farm purposes. Yields of such wells near site 4 range from 0.5 to $50 \mathrm{gal} / \mathrm{min}$. Specific capacities are substantially lower than those of wells at the other sites in the study area, ranging from 0.01 to $0.83(\mathrm{gal} / \mathrm{min}) / \mathrm{ft}$ of drawdown. Water quantity in the vicinity of site 4 is inadequate to serve the population and many residents have difficulty obtaining enough water from domestic wells for household use. The City of Lambertville obtains public water supplies from surface-water sources, partly because of the lack of adequate ground-water resources. Ground-water quality is good with the exception of hardness and iron concentrations, which commonly exceed USEPA secondary drinking-water standards (U.S. Environmental Protection Agency, 1979).

Site 5 is located in North Brunswick Township, Middlesex County (fig. 2). Borehole 231076 was drilled in the lower part of the Passaic Formation, $175 \mathrm{ft}$ northeast of an unused irriga- 
tion well (23-1083). The site is $0.8 \mathrm{mi}$ due northeast (not along dip) of the contact with the Lockatong Formation (fig. 1). Site 5 is about 1 mi north of the surface exposure of the unconformable contact with the poorly consolidated Cretaccous Raritan Formation of the Coastal Plain Physiographic Province. A small Jurassic diabase intrusion crops out 0.5 mi updip from the site. Soil at the site is composed of plastic red clay. The surface-water body nearest to site 5 is an unnamed creck that drains into Lawrence Brook. The site is in the Raritan River Basin, on a topographic high between the Lawrence Brook and Millstone River drainage basins.

The depth of the casing in the adjacent irrigation well is similar to that of the borehole; therefore, the irrigation well was used to collect caliper, borehole-televiewer, and gamma-spectra $\operatorname{logs}$ after borchole 23-1076 was sealed. The elevation of land surface at well 23-1083 is $10 \mathrm{ft}$ lower than that at borchole 23-1076. This difference necessitates an adjustment of $10 \mathrm{ft}$ when comparing the logs of the well and borchole.

Yiclds of wells in the Passaic Formation in North Brunswick Township range from 1.5 to $50 \mathrm{gal} / \mathrm{min}$ for domestic wells and from 6 to $380 \mathrm{gal} / \mathrm{min}$ for industrial wells. Specific capacities of wells in the lower part of the Passaic Formation in this area range from 0.01 to

$8.33(\mathrm{gal} / \mathrm{min}) / \mathrm{ft}$ of drawdown. Water is used primarily for industrial, domestic supply, irrigation, and firc-protection purposes. There are no known water-supply problems. Water in the area is hard; concentrations of iron and manganese are higher than the USEPA's secondary drinkingwater standards (U.S. Environmental Protection Agency, 1979).

Site 6 is located in Wallington Borough, Bergen County, in northeastern New Jersey (fig. 2). Three wells (03-286, 03-287, and 03-288) were drilled at the site, about 5.5 mi updip from the Jurassic Orange Mountain Basalt (fig. 1). Open intervals of the wells are in the lower to middle part of the Passaic Formation. About 5 mi updip from site 6 is the conformable contact with the Lockatong Formation. Thus site 6 is stratigraphically higher in the Passaic Formation than sites 4 and 5. The strata in the area of site 6 strike N. $30^{\circ}$ E. and dip about 16NW. (Hugh Houghton, New Jersey Geological Survey, written commun., 1989). Local outcrops are dominated by red, silty mudstones with some interbedded sandstones. Olsen (1980) describes the Passaic Formation in the northeastern part of the Newark Basin as coarser grained than the chronostratigraphically equivalent sections of the same formation in the central part of the basin. Depth of weathering is significant (up to about $50 \mathrm{ft}$ ). The rock weathers to thick, plastic, red, silty clay.

The Hackensack River, the largest surface-water body in the area, has an average flow of $98.5 \mathrm{ft}^{3} / \mathrm{s}$ for the period of record (1921-91). The river is tidally influenced up to the area of site 6 . The Hackensack River has a broad, marshy floodplain, which overlies as much as $150 \mathrm{ft}$ of glaciofluvial sand, silt, and clay deposits. The surrounding ridgetops reach an average of $120 \mathrm{ft}$ above sea level.

Yields of wells in the vicinity of site 6 are moderate to high. Water in the area is used primarily for industrial and public supply purposes, with minor amounts used for domestic purposes. The yields of industrial and public supply wells range from a minimum of $45 \mathrm{gal} / \mathrm{min}$ to $380 \mathrm{gal} / \mathrm{min}$. Specific capacities range from 0.35 to $8.33(\mathrm{gal} / \mathrm{min}) / \mathrm{ft}$ of drawdown. Groundwater quality is generally good; however, the USEPA maximum contaminant levels for TCE $(5 \mu \mathrm{g} / \mathrm{L})$ and 1,2-dichloropropane $(5 \mu \mathrm{g} / \mathrm{L})(\mathrm{U} . \mathrm{S}$. Environmental Protection Agency, 1994) were exceeded in samples collected from nearby industrial wells and two nearby observation wells. 
Hardness and sulfate concentrations in water in the area of site 6 commonly exceed USEPA secondary drinking-water standards (U.S. Environmental Protection Agency, 1979).

\section{METHODS OF INVESTIGATION}

Eleven boreholes were drilled into fractured bedrock at six sites. Continuous cores were collected from all boreholes. Eight of the eleven boreholes were completed as observation wells after the cores were removed for analysis. The cores were used for lithologic description, fracture-orientation and fracture-density analyses, bulk-rock chemical analyses, and additional mineralogic analyses, such as defining the distribution of various secondary minerals. Suites of various types of geophysical logs were completed in each borehole (and, where possible, in nearby production wells) to determine the physical properties of the aquifer. Samples were collected from the observation wells for water-quality analyses. The three wells not completed as monitoring wells were sealed with grout in accordance with State regulations. Types of logs obtained, methods used to interpret borehole geophysical logs, and methods used to determine lithology and correlate rock units from geophysical logs are presented in this section. Methods used to determine fracture orientation from geophysical (borehole-televiewer) logs and core samples and the technique used to determine fracture density are described in detail, as are methods used in the analysis of whole-rock chemistry. Although standard methods generally were used to collect data for the study, a new technique for gross fracture-density analysis was designed.

\section{Geologic Investigations}

Radioactive strata were identified by the use of gamma and gamma-spectral geophysical logs. Concentrations of uranium and thorium in whole-rock samples were determined by means of gamma spectrometry or chemical techniques. Geophysical logs including caliper, single-pointresistance, spontaneous-potential, and borehole-televiewer logs were used to identify highly fractured zones. Fracture-density analysis then was used in conjunction with the geophysical logs to identify the presence of those highly fractured zones that potentially could be water-bearing. Heat-pulse flowmeter and temperature profiles, when collected, were used to quantify approximate rates of and, in some cases, approximately identify zones of ground-water flow. Fracturesurface mineralogy and results of water-sample chemical analyses were used to classify the geochemistry of the circulating water, which affects radionuclide solubility. In this way, the potential for interaction between radioactive strata and circulating water in these fractured rocks was ascertained.

\section{Well Construction and Development}

A combination of drilling procedures was used to complete the eight borcholes at sites 2 , 4 , and 6 . First, a downhole hammer was used with a casing driver to emplace the outer casing (8-in. ID (inside diameter)) through overburden to a depth of at least $5 \mathrm{ft}$ into competent bedrock. An inner casing (4-in. ID) with a plastic cap on the bottom was installed within the outer casing and cemented into place. The outer casing was removed, and the annular space was grouted to the surface. A tri-cone roller bit then was inserted through the inner casing to drill through the plastic cap at the end of the inner casing. Wireline coring tools, including diamond coring bits (2.95-in. O.D.(outside diameter) and 1.9-in. I.D.), a 10 -ft core barrel (2.15-in. O.D. and 1.9-in. I.D.), and drilling rods (2.9-in. O.D. and 2.4-in. I.D.) were used to collect continuous cores of competent 
rock. Cores were retrieved in pieces as much as $10 \mathrm{ft}$ long by using the wireline method. Cores were labelled to indicate depth and orientation and were described on site. Cores were stored in 4-ft-long wooden boxes.

A slightly different method was used to complete the three boreholes at sites 1, 3, and 5 because these boreholes were not completed as observation wells. Water-lubricated rotary drilling methods were used to drill through the overburden to a depth of $5 \mathrm{ft}$ into the competent bedrock. Steel casing (6-in. O.D.) was lowered into the hole and grouted in place by the addition of grout to the annular space. Wireline coring tools were used to collect continuous cores of competent rock, as described above. When drilling was completed, the coring tools were removed, the well was sealed with grout in accordance with State regulations, and the casing was removed.

Information regarding the completion of each borehole and well, including well depth, depth to top of open interval, elcvation of land surface, latitude and longitude, category of site use, well yield, and geologic formation, is given in appendix A. Most of the boreholes were sampled, and geophysical logs were obtained. Some of the information in appendix A, including well yields and completion information for adjacent production wells at the sites where such wells were present, was retrieved from the USGS Ground Water Site Inventory data base. Well-yield information for the production wells cannot be compared directly to that for the boreholes, however, because the diameter of the production wells is larger than that of the boreholes.

The borcholes completed as observation wells were developed by either overpumping or a combination of surging with compressed air and pumping. The observation wells were completed with a threaded well cap over which a cover was placed, and a continuous water-level-monitoring device was installed.

\section{Geophysical Logging}

A suite of geophysical logs was completed in cach borehole. Gamma logs, spontancouspotential logs, and single-point-resistance logs were run in all of the boreholes. Caliper logs were run in nine boreholes. In addition, the USGS Geophysical Logging Research Group from Denver, Colorado, ran borehole-tcleviewer logs, gamma-spectral logs, and heat-pulse flowmeter logs in five wells at four sites. The logs of boreholes at each site presented in this report are listed in table 1. In some cases, logs were run in adjacent production wells that were more accessible for logging purposes than the boreholes; these also are indicated in table 1. For some of the sites, other previously installed wells in the area also were logged. Logs of previously installed wells were compared to logs of the borcholes drilled for this study (table 1). Completion information for each of these wells also is given in appendix A.

\section{Use of geophysical logs}

The geophysical logs collected for this study can be grouped into the following categories: nuclear logs (gamma and gamma spectra), clectric logs (single-point-resistance and spontaneouspotential), acoustic logs (borchole-televiewer), and miscellaneous borehole-condition logs (caliper, temperature, heat-pulse flowmeter). 
Table 1. Types of logs completed in boreholes, test wells, observation wells, and production wells, Newark Basin, New Jersey

[USGS well-identification number is two-digit county code followed by a digit sequence number]

\begin{tabular}{|c|c|c|c|c|c|c|c|c|c|}
\hline $\begin{array}{c}\text { Site } \\
\text { number } \\
\text { (see fig. 2) }\end{array}$ & $\begin{array}{c}\text { USGS well- } \\
\text { identification } \\
\text { number }\end{array}$ & $\begin{array}{c}\text { Fracture } \\
\text { density } \\
\text { (from rock } \\
\text { core) }\end{array}$ & Gamma & $\begin{array}{l}\text { Gamma- } \\
\text { spectral }\end{array}$ & $\begin{array}{c}\text { Spontaneous- } \\
\text { potential }\end{array}$ & $\begin{array}{l}\text { Single- } \\
\text { point- } \\
\text { resistance }\end{array}$ & Caliper & $\begin{array}{l}\text { Borehole- } \\
\text { televiewer }\end{array}$ & $\begin{array}{l}\text { Heat-pulse- } \\
\text { flowmeter }\end{array}$ \\
\hline \multirow[t]{3}{*}{1} & $23-800$ & & $X$ & & & & & & \\
\hline & $23-801$ & & $\mathrm{X}$ & & & & & & \\
\hline & $23-932$ & $X$ & $\mathrm{X}$ & & $\mathrm{X}$ & $\mathrm{X}$ & $X$ & & \\
\hline \multirow[t]{3}{*}{2} & $21-358$ & $X$ & $X$ & $X$ & & & $X$ & $X$ & $X$ \\
\hline & $21-359$ & $X$ & & & & & & & \\
\hline & $21-383$ & & $\mathrm{X}$ & & $X$ & $X$ & $\mathrm{X}$ & & \\
\hline \multirow[t]{3}{*}{3} & $21-159$ & & $X$ & $\mathrm{X}$ & & & $\mathrm{X}$ & $X$ & \\
\hline & $21-289$ & & $X$ & & & & $X$ & & \\
\hline & $21-290$ & $x$ & $\mathrm{X}$ & & $X$ & $\mathrm{X}$ & & & \\
\hline \multirow[t]{5}{*}{4} & $19-085$ & & $\mathrm{X}$ & & & & & & \\
\hline & $19-249$ & $\mathrm{X}$ & $X$ & & $\mathrm{X}$ & $\mathrm{X}$ & $X$ & & \\
\hline & $19-250$ & $X$ & $X$ & $\mathrm{X}$ & $\mathrm{X}$ & $\mathrm{X}$ & $\bar{X}$ & $\mathrm{X}$ & $X$ \\
\hline & $19-251$ & $X$ & $X$ & $\mathrm{X}$ & $\bar{X}$ & $X$ & $X$ & $\bar{X}$ & $X$ \\
\hline & $19-285$ & & $X$ & & & & & & \\
\hline \multirow[t]{2}{*}{5} & $23-1076$ & $X$ & $\mathrm{X}$ & & & & & & \\
\hline & $23-1083$ & & $X$ & $X$ & $X$ & $X$ & $X$ & $\bar{X}$ & \\
\hline \multirow[t]{3}{*}{6} & $03-286$ & $X$ & $X$ & & $X$ & $X$ & $X$ & & \\
\hline & $03-287$ & $\mathrm{X}$ & $\mathrm{X}$ & & $\mathrm{X}$ & $X$ & $X$ & & \\
\hline & $03-288$ & $X$ & $\bar{X}$ & & $\mathrm{X}$ & $\mathrm{X}$ & $X$ & & \\
\hline
\end{tabular}


Gamma logs are reliable indicators of the presence of radioactive rock. The gamma log was used to record the gamma radiation in all energy ranges emitted by strata that can be detected by a sodium-iodide (NaI) scintillation detector (Keys, 1990). Stationary gamma spectra show (in selected stratigraphic intervals) the peak energy, which was used to identify the primary source of the gamma radioactivity. Gamma radioactivity originates from the three abundant naturally occurring radioisotopes-- ${ }^{238} \mathrm{U}$ (uranium-238), ${ }^{232} \mathrm{Th}$ (thorium-232), and ${ }^{40} \mathrm{~K}$ (potassium-40). Both ${ }^{232} \mathrm{Th}$ and ${ }^{238} \mathrm{U}$ are low-energy gamma emitters; therefore, the gamma spectra energies measured are those of their progeny in the respective radioactive-decay series. The presence of ${ }^{238} \mathrm{U}$-series isotopes was verified by identifying the presence of gamma emissions from ${ }^{214} \mathrm{Bi}$ (bismuth-214), which produces energies of 2.024, 1.764, 1.379, 1.238, 1.120, 0.769, and 0.609 million electron volts $(\mathrm{MeV})$. The presence of ${ }^{232} \mathrm{Th}$-series isotopes was verified by identifying the presence of gamma emissions from ${ }^{208} \mathrm{Tl}$ (thallium), which produces energies of $2.614,0.533$, and $0.511 \mathrm{MeV}$. The presence of potassium was verified by identifying the presence of gamma emissions from the ${ }^{40} \mathrm{~K}$ isotope, which produces an energy of $1.46 \mathrm{McV}$ (Taylor, 1989; Fertl, 1979). Characteristic gamma-energy signatures of the three decay series are shown in figure 3. Visual inspection of the gamma energy intensities were used to evaluate the presence of ${ }^{214} \mathrm{Bi}$, ${ }^{208} \mathrm{Tl}$, and ${ }^{40} \mathrm{~K}$ in rock strata with high total gamma activity.

Barium $\left({ }^{133} \mathrm{Ba}\right)$ and cobalt $\left({ }^{60} \mathrm{Co}\right)$ are characterized by known energy peaks that often are used to calibrate the spectral tool (fig. 4). In order to stabilize the drift in gain of the gamma-spectral tool down the hole, the ${ }^{133} \mathrm{Ba}$ source is mounted in the tool and is part of the spectrum and, therefore, is identified along with the naturally occurring spectrum. The total integrated counts for 1,024 channels (energy $0-3 \mathrm{MeV}$ ), including the stabilization source of ${ }^{133} \mathrm{Ba}$, are determined for each stationary spectra collected in the boreholes. Corrections were not made for the differences in counting times because background was not stripped from the spectra.

Electric logs are useful for determining variations in lithology within rock penetrated by the borehole. The single-point-resistance log measures the electrical resistance between an electrode on the logging probe and a surface-ground electrode or a ground electrode on the probe (Keys, 1990). Variations in resistance reflect variations in resistivity of the rock and allow delineation of lithologic units. Spontaneous-potential logs record the natural electrical potential that exists between the electrode on the logging probe and the surface-ground electrode. This potential is caused primarily by electrochemical reactions that reflect differences in salinity between fluid in the borehole and that in the rock (Keys, 1990). Sharp deflections on both the single-point resistance and spontaneous-potential $\log$ at the same depth interval may indicate the presence of a water-bearing fracture.

The borehole televiewer (BHTV) produces a magnetically oriented image of the borehole wall by transmitting ultrasonic pulses through the borehole fluid to the rock which is reflected back to the transducer. The acoustic reflectivity is a function of the amplitude of the reflected signal. Minimum reflection is detected at a fracture trace or at other types of openings that intersect the boreholc. In some cases, the BHTV may be more accurate than the core as an indicator of fracture depth because its depth scale is more consistent (Davidson and others, 1982). The BHTV 


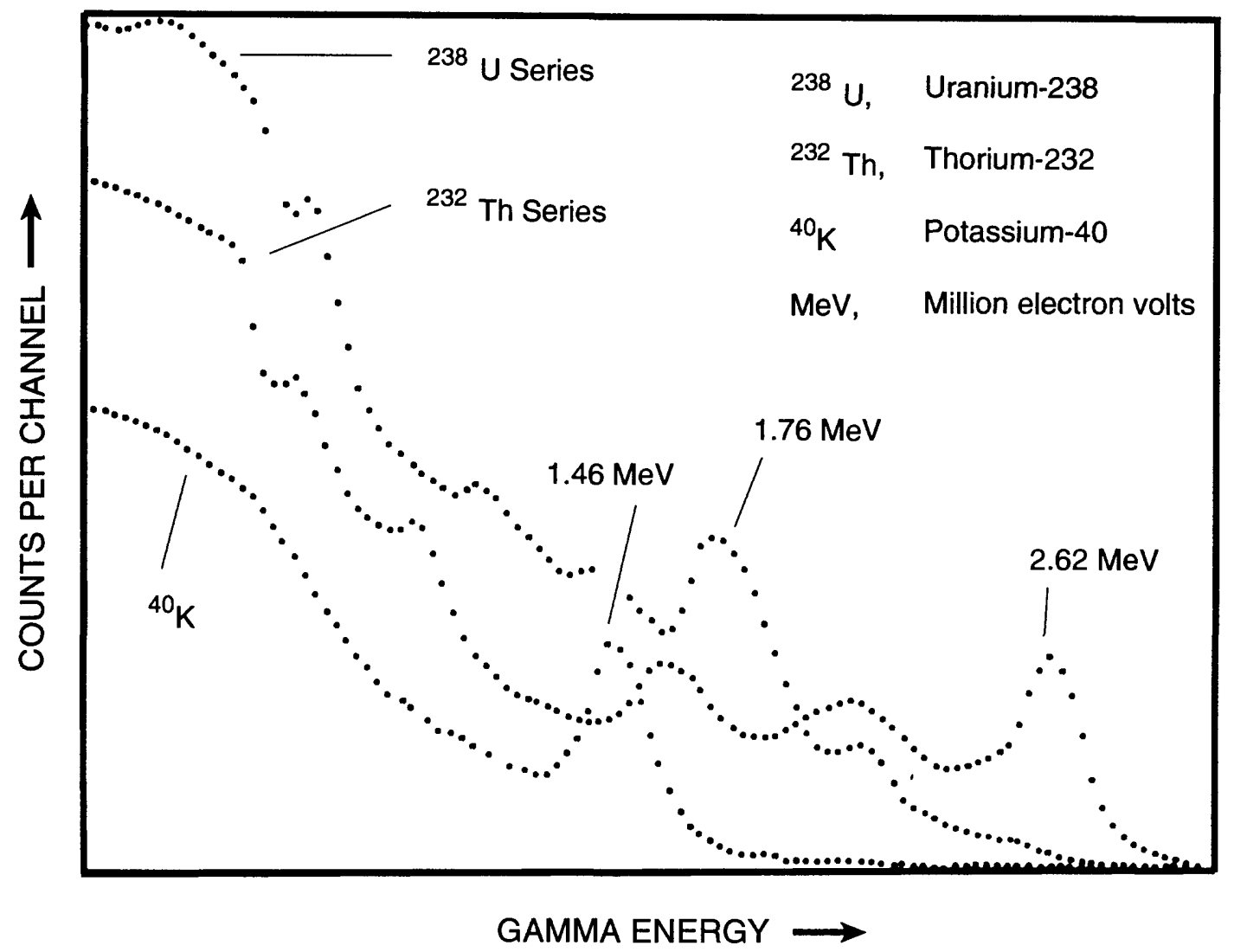

Figure 3. Schematic gamma-energy signatures of uranium-238, thorium-232, and potassium- 40 showing energies of the major peaks identified by means of gamma-spectral logging. (Modified from Keys and MacCary, 1971.)

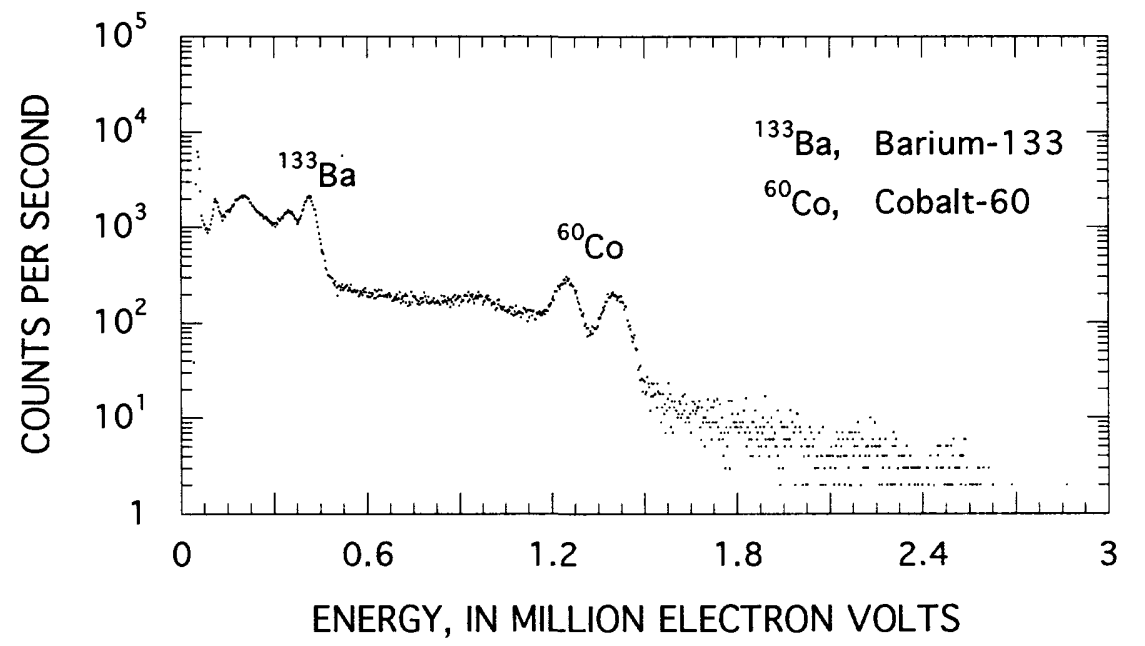

Figure 4. Known energy peaks used to calibrate stationary gamma-spectra logs. 
also provides the information necessary to calculate the strike and dip of the fractures and bedding planes. The direct image provided by the BHTV is as if the borehole were split vertically at magnetic north, unfolded, and laid flat (Zemanek and others, 1969). The basic interpretation achieved by using the BHTV display to calculate the strike and dip of planar features is shown in figure 5 . The minimum dip angle that could be interpreted in these boreholes is $10^{\circ}$. Fractures were so dense in some zones that dip angle could not be clearly determined. All interpretations incorporate the assumption that the holes are vertical because deviation from the vertical was not determined. The magnetic declination for the area of the study sites is $\mathrm{N} .12^{\circ} \mathrm{W}$; because W. declination is considered negative, $-12^{\circ}$ was used in the calculation of the strikes. All fractures shown on the BHTV image were hand-sketched on a compressed scale to illustrate fracture distribution along the entire lengths of the logged borcholes.

Although various borehole-condition logs can be used to measure physical properties of the borehole, they also can provide significant information about fracturing and flow in open boreholes. Caliper logs record the diameter of the borehole as a function of depth (Keys, 1990). Borehole diameter commonly varies because fracture zones are present in the rock. Temperature logs are used to detect temperature anomalies in a well that differ from the thermal gradient (Keys, 1990). Temperature anomalies are used to detect intervals of rock in which the borehole fluid flows into or out of the adjacent rock. The heat-pulse flowmeter (HPFM) is used to measure the vertical velocity and direction of flow within the borehole. Flow data were recorded with the HPFM as stationary-point measurements. Water moving vertically in the well flows through a resistance-wire grid in the HPFM. A pulse of electric current is triggered for a millisecond through the wire grid, thereby heating the water in contact with it. The travel time for the heated water to reach the thermistor ( $20 \mathrm{~mm}$ away) either above or below the grid is recorded. A positive response indicates upflow and a negative response indicates downflow (Hess, 1982). All of these logs were used in combination to determine the depths of fracture zones in which flow may be significant.

\section{Stratigraphic correlations determined from geophysical logs}

At each study site, anomalously radioactive zones were correlated horizontally by comparing qualitatively the shapes of gamma logs of the wells at the site. Similar distribution patterns of anomalous gamma peaks in intervals of strata indicate possible lateral continuity of radioactive zones. These distribution patterns include the vertical distance separating distinct anomalous peaks, the relative magnitudes of peaks that might be correlative, and the patterns of gamma background radiation in possible correlative zones.

The dip angle of the possibly correlative strata was calculated by assuming planar continuity of the radioactive zones between boreholes. First, an average strike was determined on the basis of field measurements made near the study site (Hugh Houghton, New Jersey Geological Survcy, written commun., 1989). The gamma logs of the boreholes were then projected onto a single vertical plane aligned along the dip trend. The dip angle was calculated from the vertical displacement of strata that were assumed (on the basis of the presence of anomalous gamma peaks) to be correlative between boreholes. The calculated dip angles were checked to verify that they were within the range of error of field measurements of the dip at outcrops. Assumed stratigraphic planar continuity was considered to be verified where the calculated dip angle based on 


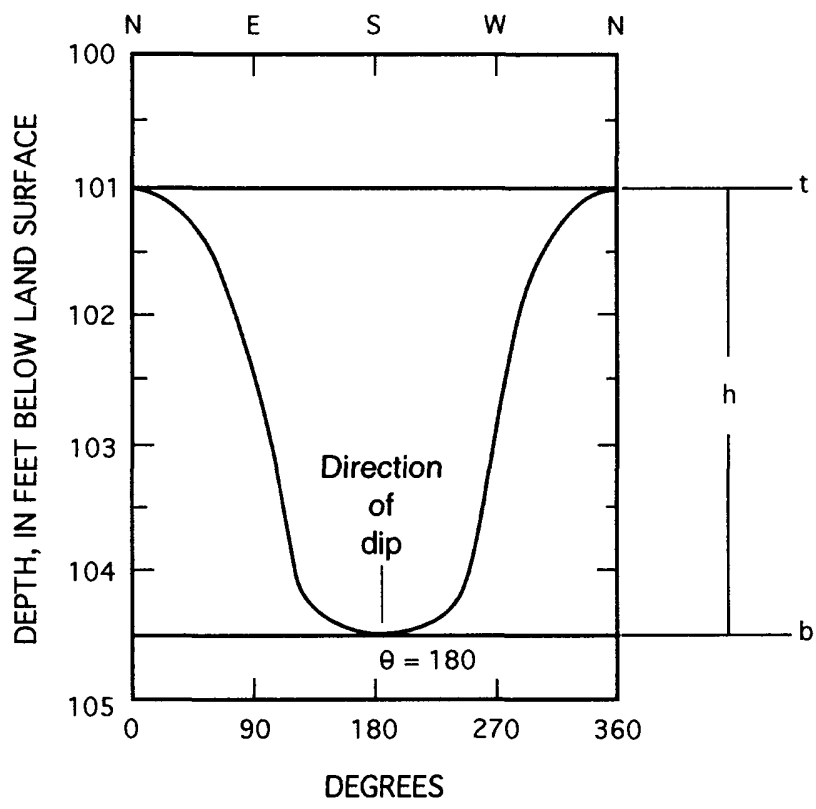

$$
\text { Dip }=\tan ^{-1}\left(\frac{h}{d}\right)
$$

Strike $=\theta \pm 90^{\circ}$

\section{EXPLANATION}

$h=$ height of fracture

$\theta=$ direction of dip, in this case, 180 degrees

$\mathrm{d}=$ borehole diameter

$\mathrm{t}=$ top of fracture

$b=$ bottom of fracture

Figurc 5. Example interpretation of fracture orientation from a borehole-televiewer imagc where magnetic declination is -12 degrees. 
gamma logs agreed with the dip angle measured in the field within the range of error of the dipangle measurements. A measurement error of $\pm 5^{\circ}$ was assumed for both strike and dip angles measured in the field, which results in an crror in vertical displacement of about \pm 9 percent.

Measurements of horizontal distance between boreholes were made on 2-1/2 minute quadrangle maps. Horizontal error was assumed to be the sum of a map-location error of 1 minute (equal to about $75 \mathrm{ft}$ ) and a measuring-scale error of $\pm 0.02 \mathrm{in}$. ( $40 \mathrm{ft}$ ), for a total horizontal error of $\pm 115 \mathrm{ft}$. This total horizontal error generally was about \pm 10 percent of the measured horizontal distance in the sections. Because the error from these sources could be significant, the planar lateral continuity of the radioactive zones is difficult to verify.

\section{Determination of Lithology and Fracture Density}

Continuous cores were collected to obtain detailed lithologic descriptions of radioactive and nonradioactive strata in the stratigraphic sections at the six sites and to determine the stratigraphic relation between radioactive and nonradioactive strata. In order to determine the relation of hydrologic properties to lithologic characteristics, fracture orientations were assigned one of two categories--bedding-plane and low-angle or high-angle and vertical--and the frequency of occurrence of these two types of fractures in each core was recorded. Fracture-density and fracture-orientation data from lithologic descriptions were compared to data from geophysical logs.

\section{Lithology}

Detailed lithologic columns were assembled from standard lithologic descriptions. Cores were examined with a hand lens at the drilling site, and a lithologic description was made. Color designations were made by comparing dry samples with a Rock Color Chart (Geological Society of America, 1948). Grain sizes were determined by comparing the samples with sand-grain charts size-graded according to the Udden-Wentworth classification (U.S. Geological Survey, 1980; Blatt and others, 1980). A hand-held scintillometer was used in the field to determine the average number of gamma counts per second (within \pm 5 percent) at 0.5 - or 1.0 -ft intervals over the length of the core. This information was used to locate zones of anomalously radioactive rock material (accuracy $\pm 0.5 \mathrm{ft}$ ).

\section{Fracture density}

Fracture density was determined for all cores by recording the number of fractures observed per $5 \mathrm{ft}$ of core. A minimum size of $1 \mathrm{~mm}(0.04 \mathrm{in}$.) was chosen for fracture counting because it was considered to be the smallest reasonably measureable unit that could be expected to transmit water. Fractures that splayed off from a main fracture were not counted separately from the main fracture. Also, fractures that terminated in the core were not counted, as they could not be assumed to be connected to other water-bearing fractures. (Regardless of fracture character in the core (or the borehole wall), fractures must be interconnected over some minimum distance for water to flow.) Results were compiled in histograms (pls. 2, 4, and 6). The depth interval in which fracture-density counts were initiated is listed individually for each well or borehole in the descriptions of individual sites in appendix D. 
Fractures were categorized according to their orientation and whether they were open or sealed in the strata penetrated by the borehole. Fractures that were horizontal or nearly parallel to bedding were considered to be low-angle fractures. Because bedding planes dip from $5^{\circ}$ to $30^{\circ}$ at these sites, bedding-plane fractures were classified as low-angle fractures. Fractures that were skewed by more than $45^{\circ}$ from the horizontal were considered to be high-angle fractures.

An open fracture was defined as one in which the two pieces of rock on either side of the fracture were not connected by fracture-filling material. A sealed fracture was defined as one in which the rock on either side of the fracture was sutured by the fracture-filling material. The mineralogic composition of the fracture-filling material was determined by observation with a hand lens. Sealed fractures were counted because they potentially can transmit water if minor interconnected openings are present between the fracture filling and the wall rock, but they probably are less effective than open fractures. Also, fractures that are sealed in one place may be open elsewhere in the rock strata. Although secondary-mineral sealing can be so complete as to obliterate the ability of the fracture, regardless of its thickness, to transmit fluids, heterogeneous precipitation of secondary fracture-filling minerals or heterogeneous dissolution of these minerals during weathering can provide conduits for fluid movement. Therefore, sealed fractures greater than 35 microns in thickness (Snow, 1968) may be effective in conducting water.

The fracture-density counts from the 5-ft-long sections of core from all the boreholes and wells were grouped by quartile distribution of the number of fractures as follows: 0 to 2 (an unfractured or sparsely fractured interval), 3 to 5 (a slightly fractured interval), 6 to 8 (a moderately fractured interval), and 9 to 32 (a highly fractured interval) (fig. 6). These terms are used hereafter in the report. Fissured zones were counted separately. Fracture-density data for the section from 10 to $129 \mathrm{ft}$ below land surface, and for successive 100 - $\mathrm{ft}$ sections for each core, were described further on the basis of quartile distribution with depth intervals and rock type. Quartile distributions of fracture orientation (vertical and horizontal) also were determined. Where many sparsely and slightly fractured $5-\mathrm{ft}$ intervals were found in succession, the section of strata was termed a "sparsely fractured section," whereas where several or many moderately or highly fractured 5-ft intervals were found in succession, the term "highly fractured section" was used (fig. 6). The highly fractured section immediately below the regolith, termed the "transition zone" (Harned, 1989), varies in thickness (commonly $20-50 \mathrm{ft}$ ) and is underlain by sparsely to moderately fractured bedrock.

A fissured zone was defined as any zone that was broken by many interconnected cracks (American Geological Institute, 1976) that could not be quantified. Fissured zones generally ranged from 3 in. to more than $3 \mathrm{ft}$ in thickness. Although the fissured zones were not classified as either high-angle or low-angle open fractures in the histograms, they appeared to be predominantly horizontal or along bedding planes. Because fissured zones can transmit significant quantities of water, classifying them in this way may underrepresent their effectiveness; that is, one fissured zone may transmit more water than several individual fractures.

Determining the exact depth and width of a fissured zone was not always possible because recovery of the core from such intervals was infrequent. Missing sections of strata most likely consisted of brecciated rock that was removed from the core by circulating drilling fluid. This situation commonly is encountered in highly fractured rock (Davidson and others, 1982). Presence of a fissured zone was reported as within the 5-ft interval of the core in which it was located 


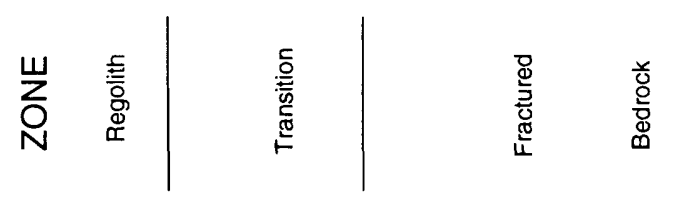

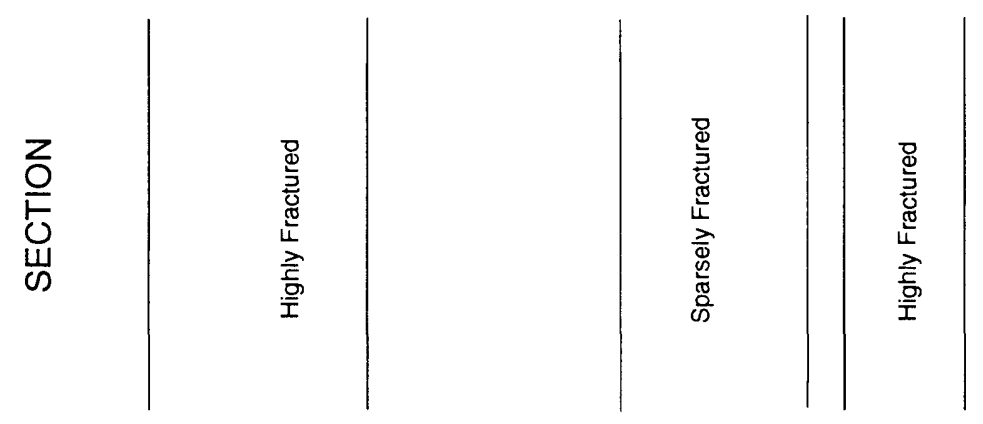

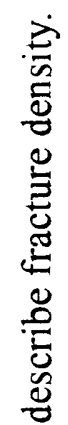

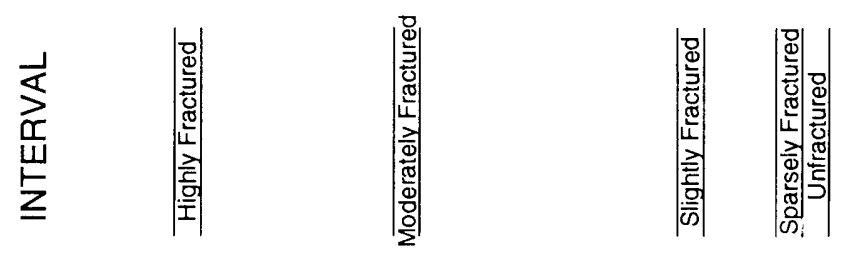

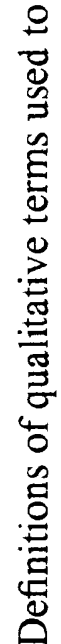

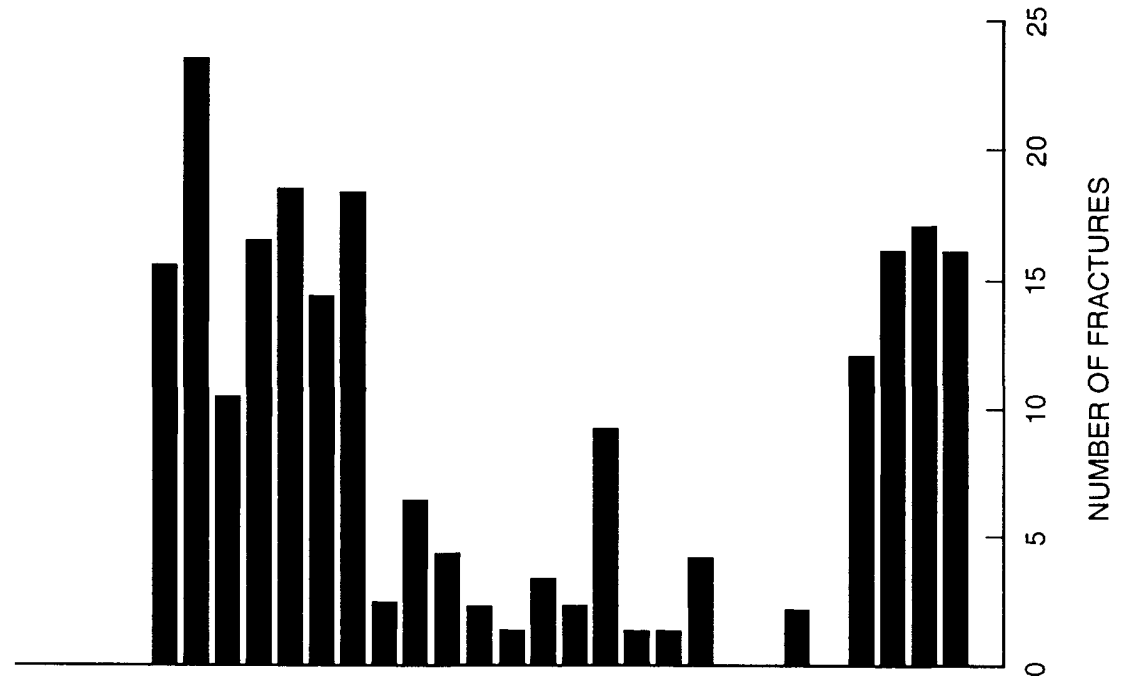

它

啘崖

$H \perp d \exists O$ 
in the fracture-density histograms, but the exact depth below land surface is given only in those instances in which the driller noted the presence of such a zone by a sudden increase in drilling speed, often followed by jamming of the drill bit as a result of the wedging of angular fragments of rock between the core barrel and drilling rod.

This method of fracture-density analysis is limited by many factors, especially the small scale of the core. A 2-in.-diameter area on a fracture surface may not represent the orientation, openness, or fracture-filling mineralogy of the extended fracture planc.

Another limitation is the difficulty in distinguishing between fractures and a broken core. Most fractures can be easily differentiated from breakage by the presence of minerals coating the fracture face and the absence of a conchoidal breakage pattern. Fissile mudstones, however, break easily along smooth planes; therefore ambiguous openings in rocks of this type were not counted as fractures. The accuracy of the ratio of open to sealed fractures is limited by the fact that sealed fractures can break during drilling, core retrieval, or core transport. Therefore, open fractures probably are overrepresented in the fracture count. Also, the ratio of open to sealed fractures is skewed by the arbitrary minimum size of $1 \mathrm{~mm}$ for counting sealed fractures.

To ensure maximum consistency, all fractures were counted and characterized by one geologist (the third author). Reproducibility of fracture-density data was ensured by making three separate counts of the fractures in selected sections of core. The counts were conducted intermittently during the analysis of all the cores. The discrepancy for a fracture category was calculated as the greatest difference between any of the counts and the average for that category, divided by the average for the category, expressed as a percentage. For the high-angle open-fracture category, the discrepancy was 1 percent; for the low-angle open-fracture category, the discrepancy was 5 percent; for the high-angle sealed-fracture category, the discrepancy was 8 percent; and for the low-angle sealed-fracture category, the discrepancy was 10 percent. Discrepancies can be attributed to errors in measurement of fracture thickness, to errors in counting, and to the possible inconsistent categorization of features that are ambiguous or rare (such as multiple, thin, parallel, and interconnected sealed fractures, or incompletely sealed fractures).

\section{Analysis of Whole-Rock Chemistry}

In order to quantify the elevated concentrations of naturally occurring radionuclides in the rock matrix of the aquifers as indicated by gamma logs, gamma-spectrometric measurements were made of radioactivity emitted by uranium, thorium, and potassium in core samples. The 28 samples selected for measurement were distributed almost evenly between highly radioactive and nonradioactive rock. Nine samples were from the Stockton Formation at site 1,8 samples were from the lower part of the Passaic Formation at site 3, and 11 samples were from the lower part of the Passaic Formation at site 5. The depth intervals from which samples were chosen for analysis are identified in the stratigraphic columns on plates 1,3 , and 5 .

The 28 rock samples, each weighing $50 \mathrm{~g}(1.76 \mathrm{oz})$, were crushed to pass through a 200mesh sieve. At a contract laboratory, radioactivity of the powdered rock samples was counted in a fixed geometry for $60 \mathrm{~min}$ by using a standard 3-in.-by-3-in. high-sensitivity NaI detector (Durrance, 1986), which was calibrated with samples of natural uranium in secular equilibrium. Laboratory precision was equal to the value of the minimum reporting limit for each constituent 
(cquivalent uranium (eU) $2 \mathrm{ppm}$, cquivalent thorium (cTh) $5 \mathrm{ppm},{ }^{40} \mathrm{~K} 0.5$ percent, and gross gamma radiation $0.1 \mathrm{ppm}$ as $\mathrm{eU}$ ), or 10 percent of the reported value, whichever was larger.

Potassium concentration was determined directly from radioactivity of ${ }^{40} \mathrm{~K}$; the eU concentration was determined from radioactivity measured at the high energy peak of $1.76 \mathrm{MeV}$ of ${ }^{214} \mathrm{Bi}$; and cTh concentration was determined from radioactivity measured at the high energy peak of 2.61 $\mathrm{MeV}$ of ${ }^{208} \mathrm{Tl}$ (Durrance, 1986). Crushed-rock samples were kept in a sealed container for 21 days before gamma-spectrometric measurements were made to allow for ingrowth of ${ }^{214} \mathrm{Bi}$ to compensate for potential loss of gaseous ${ }^{222} \mathrm{Rn}$ during crushing of the rock. For purposes of calculating eU, secular equilibrium for all uranium decay-series progeny was assumed. Disequilibrium between uranium and its ${ }^{214} \mathrm{Bi}$ progeny is possible, however, because uranium and radon typically are highly soluble in the natural environment and can be leached from the rock by percolating water, whereas radium is moderately soluble and is less likely to be leached.

Two samples of quartz powder mixed with different proportions of USEPA thorium and uranium standards also were submitted for analysis for the purpose of quality assurance. Results of analysis of one of the two uranium standards fell within precision limits of the known value for the sample (app. B-2). Results of the analysis of the second uranium standard were 19 percent higher than the expected value, exceeding the precision limit estimate of \pm 10 percent. Because a large range of uranium concentrations was observed in the rock samples (three orders of magnitude), error slightly greater than 10 percent is acceptable for the purpose of distinguishing the high uranium content in radioactive strata from the low uranium content in nonradioactive strata. Results of analyses of both thorium standards were low, by 16 and 22 percent, indicating a possible low bias of the analysis relative to the true thorium concentration. This low bias was not sufficiently large, however, to explain the uranium/thorium ratio, which was higher in most of the samples than the expected 1:4 ratio in crustal sediment.

As an additional quality check on the uranium content of the rock samples analyzed by using gamma spectrometry, uranium concentration also was determined at the contract laboratory by using the USEPA-approved fluorometric method (Krieger and Whittaker, 1980). One g (0.04 oz) of the crushed-rock sample was digested overnight in hydrofluoric acid (HF), and the uranium in solution was recovered. Uranium recovery was monitored through the use of spiked aliquots. Results of fluorometric uranium analysis were lower than expected in both quality-assurance samples; results of analysis of sample QA-1 (app. B-2) were significantly lower than expected, indicating a low bias in results obtained with this technique by the contract laboratory. The low bias associated with the fluorometric analysis most likely resulted from incomplete dissolution of the sample; the high bias associated with the gamma-spectral analysis may have resulted from incomplete subtraction of background radioactivity or lack of secular equilibrium of ${ }^{238} \mathrm{U}$ with its ${ }^{214}$ Bi progeny.

To illustrate differences in chemical composition between radioactive and nonradioactive strata, a subset of 9 rock samples was chosen from the 28 samples analyzed for radioactivity, so that major- and trace-element concentrations could be determined. Four of the samples were from the Stockton Formation at site 1 and four were from the lower part of the Passaic Formation at site 5 . Because the lithology at site 3 is similar to that at site 5 , whole-rock chemistry was determined for only one sample from site 3 . The depth intervals from which the nine samples were chosen are illustrated in the stratigraphic columns on plates 1, 3, and 5 and listed in appendix B-1. 
Chemical analyses of the nine crushed-rock samples were completed at the USGS Rock Analysis Laboratory in Lakewood, Colorado. A minimum of $0.4 \mathrm{~g}(0.01 \mathrm{oz})$ of crushed rock was digested in a mixture of hydrofluoric, nitric, and percloric acids. The concentrations of 40 elements (major and trace elements) were determined by using inductively coupled plasma atomic emission spectroscopy (ICP-AES) (Arbogest, 1990). Laboratory precision was reported as \pm 2 percent. No independent quality-assurance checks were made. For whole-rock samples with uranium concentrations less than $100 \mu \mathrm{g} / \mathrm{g}$, uranium and thorium concentrations also were determined by using neutron activation analysis (NAA). This technique yields high precision and accuracy even at low concentrations of these constituents without requiring digestion of the samples. In addition, concentrations of total sulfur and total and inorganic carbon were determined by infrared spectrometry following oxidation and combustion (Arbogest, 1990). Concentrations of organic carbon and silica were calculated by difference.

Concentrations of uranium and potassium in split samples that were determined by gamma spectrometry at the contract laboratory compare closely with the results of whole-rock chemical analyses determined by ICP-AES or NAA at the USGS laboratory. Concentrations of potassium determined by gamma spectrometry showed a high bias for three whole-rock samples in which gross gamma activities were high (app. B-1 and B-2) relative to the concentrations determined chemically by means of HF digestion and ICP-AES analysis. The background gammaradiation level on the potassium energy channel probably was raised to a higher value than expected by the laboratory analyst for these highly radioactive samples; therefore, the analyst may have attributed some of this "excess" background radiation to ${ }^{40} \mathrm{~K}$ activity.

Concentrations of uranium and thorium determined by gamma spectrometry are of the same order of magnitude as the chemically determined concentrations. Concentrations of thorium in all five samples from the lower part of the Passaic Formation determined by gamma spectroscopy were consistently biased low, however, relative to chemically determined concentrations. The reason for this difference is unknown; perhaps a soluble radioactive progeny of thorium, such as radium-228 $\left({ }^{228} \mathrm{Ra}\right)$, was partially removed from the mudstone by solvation. Concentrations of uranium in all four samples from the Stockton Formation determined by gamma spectrometry were consistently biased high relative to chemically determined concentrations. In the sample with the greatest concentration of uranium (black mudstone from the lower part of the Passaic Formation), however, results of gamma spectrometry show a strong low bias relative to the chemically determined uranium concentration. Although a soluble radioactive progeny of uranium, such as ${ }^{226} \mathrm{Ra}$ or ${ }^{222} \mathrm{Rn}$, may have been partially removed from the mudstone by solvation, this explanation is considered unlikcly because the mudstone from which the whole-rock sample was collected is unfractured.

\section{Analysis of Water Quality}

Samples were collected for analysis of water quality from seven of the eight completed observation wells and from one of the three boreholes before it was sealed. Samples were collected from production wells adjacent to each of the remaining two boreholes. The collected samples were analyzed to determine activities and concentrations of radioactive constituents (gross alpha-particle and gross beta-particle activity, ${ }^{238} \mathrm{U},{ }^{234} \mathrm{U}$ (uranium-234), ${ }^{235} \mathrm{U}$ (uranium${ }^{235)}{ }^{226} \mathrm{Ra},{ }^{228} \mathrm{Ra}$, and ${ }^{222} \mathrm{Rn}$ ), major ions, nutrients, and trace elements. Ficld properties, including $\mathrm{DO}, \mathrm{pH}$, Eh, temperature, and specific conductance, were monitored at the well. 
Concentrations of volatile organic compounds (VOC's) and oxygen, sulfur, and hydrogen isotope ratios were determined in selected samples.

\section{Sampling Procedures}

All samples consisted of raw water collected directly from the well by a small portable submersible pump. Samples were collected after three well-casing volumes of water had been removed from the well by pumping (Claassen, 1982), except samples from well 19-250 and well 21-358 which were collected after one to two well-casing volumes of water had been pumped. Mechanical difficulties with the pumping equipment prevented further pumping from these two wells. Pumping rates did not exceed the estimated production capacity of the wells.

Stabilization of specific conductance, $\mathrm{pH}$, and water temperature was a prerequisite for sample collection (Claassen, 1982). Stabilization of these three properties was defined by three consecutive measurements, made in 5-min intervals, that varied by less than 5 percent. These three properties generally stabilized after the removal of about one well-casing volume of water.

Water samples, unless otherwise indicated in the report, were filtered through a 0.45 micron filter into polyethylene collection bottles and preserved according to USGS protocols (Thatcher and others, 1977; Fishman and Fricdman, 1989; Wershaw and others, 1987). Reagentgrade nitric acid was added to the bottles containing samples to be analyzed for major cations, trace elements, and radionuclides to lower the $\mathrm{pH}$ below a value of 2 . Mercuric chloride was added to bottles containing samples to be analyzed for nutrients. Samples to be analyzed for dissolved organic carbon (DOC) were filtered through a 0.10 -micron silver filter into a prebaked glass bottle. Samples to be analyzed for VOC's were collected unfiltered into glass vials and capped tightly with no head spacc. Samples to be analyzed for dissolved ${ }^{222} \mathrm{Rn}$ gas were collected unfiltered into potassium-free glass liquid-scintillation vials containing premeasured amounts of mincral-oil-based scintillation "cocktail" according to methods approved by the USEPA (U.S. Environmental Protection Agency, 1978). All samples except those to be analyzed for ${ }^{222} \mathrm{Rn}$ werc storcd at $4^{\circ} \mathrm{C}$ until analysis.

\section{Analytical Procedures}

Alkalinity, DO, Eh, pH, specific conductance, and water tempcrature were monitored onsite according to the guidelines of Wood (1976). DO, Eh, $\mathrm{pH}$, and water temperature were measured in water passing through a flow-through chamber. All probes were allowed to equilibrate to the water temperature before measurements were recorded. Alkalinity was determined in the field by the incremental titration procedure (Wood, 1976). Eh was measured to show the relative differences in oxidation-reduction potential among the water samples.

Gross alpha-particle and gross beta-particle activities and concentrations of ${ }^{226} \mathrm{Ra}$ and ${ }^{228}$ Ra were determined at the NJDEP Bureau of Environmental Laboratorics Radiation Protection Laboratory in Ewing, New Jerscy. The laboratory was certified in (Pat Gardener, New Jersey Department of Environmental Protection and Energy Bureau Environmental Laboratories, written commun., 1986), and used, standard USEPA procedures (Kricger and Whittaker, 1980). The radioactivity of these aqueous constituents is reported in $\mathrm{pCi} / \mathrm{L}$ (picocuries per liter); one picocurie represents 2.2 radioactive disintegrations per minute. The degrec of error of the measure- 
ment, which results from the statistically random nature of radioactive decay, was reported by the laboratory to two standard deviations. Gross alpha-particle and gross beta-particle activities were determined by counting, in a low-background alpha-beta counter for $200 \mathrm{~min}$, the sample residue deposited on a tared, stainless-steel planchet. Gross alpha-particle and gross-beta particle activities were calculated by comparing the activity of the sample to the activities of an americium-241 standard and a cesium-137 standard, respectively.

${ }^{226} \mathrm{Ra}$ was coprecipitated with barium sulfate. The precipitate was collected by filtration through a plastic-membrane filter and was transferred to a stainless-steel planchet. Radioactivity was counted in a low-background alpha counter for $200 \mathrm{~min} .{ }^{228} \mathrm{Ra}$ was coprecipitated with lead sulfate. Actinium-228, the radioactive progeny of ${ }^{228} \mathrm{Ra}$, was allowed to ingrow for about 1 month. The lead sulfate precipitate then was dissolved, and the ingrown actinium-228 was coprecipitated with cerium oxalate and counted for $100 \mathrm{~min}$ in a low-background beta counter.

The ${ }^{222} \mathrm{Rn}$ activity of water samples contained in two premeasured, mineral-oil-based liquid scintillation potassium-free glass vials was calculated by measuring, within $48 \mathrm{~h}$ of collection, the activity of five short-lived beta-emitting daughters for $100 \mathrm{~min}$ with a liquid-scintillation beta counter (Prichard and Gesell, 1977). The average value of the two analyses is reported in appendix $C$.

Calculations were made to account for the radioactive decay during the time between collection and analysis for ${ }^{226} \mathrm{Ra},{ }^{228} \mathrm{Ra}$, and ${ }^{222} \mathrm{Rn}$. The analytical results were adjusted to represent the concentrations of these radionuclides at the time of sample collection.

Uranium-isotope $\left({ }^{238} \mathrm{U},{ }^{235} \mathrm{U}\right.$, and $\left.{ }^{234} \mathrm{U}\right)$ concentrations were determined by using standard alpha-spectrometry methods, as detailed by Osmond and Cowart (1976), at a contract laboratory supervised by the personnel of the USGS National Water Quality Laboratory (NWQL) in Arvada, Colorado. Uranium was coprecipitated with iron hydroxide. The uranium-bearing precipitate was dissolved in boiling nitric acid, and the uranium was electrodeposited on a stainless-steel filament. The abundance of the individual uranium isotopes was counted using alpha spectrometry.

When the radioactivity of a sample is so low that the measured radioactivity cannot be clearly distinguished from normal background radiation, the radioactivity of the sample is said to be below the minimum reporting limit (MRL). The MRL for gross alpha-particle and gross betaparticle activitics, and ${ }^{226} \mathrm{Ra}$ concentration was $0.5 \mathrm{pCi} / \mathrm{L}$, and for ${ }^{228} \mathrm{Ra}$ concentration was 1.0 $\mathrm{pCi} / \mathrm{L}$. The MRL for concentration of isotopes of uranium was $0.4 \mathrm{pCi} / \mathrm{L}$. The MRL for ${ }^{222} \mathrm{Rn}$ concentration was $50 \mathrm{pCi} / \mathrm{L}$. The measured activity of the sample was reported by the laboratory even when the activity was below the MRL, but the MRL, not the measured activity, is stored in the USGS QWDATA computer data base and is presented in this report.

Concentrations of major cations and anions and of trace elements were determined at the USGS NWQL by using standard methods (Fishman and Friedman, 1989). Concentrations of trace elements and major cations were measured by atomic-emission spectrometry with ICP as the excitation source (ICP-AES). Concentrations of potassium were determined by atomicabsorption (AA) spectrometry with direct aspiration of the sample into an air-acetylene flame. Concentrations of chloride and of nitrogen and phosphorus species were determined by using 
colorimetric methods. Concentrations of sulfate were measured by turbidimetry. Concentrations of DOC were determined by infrared spectrometry of carbon dioxide generated by the oxidation of the sample with persulfate (Wershaw and others, 1987). VOC concentrations were determined by gas chromatography (Wershaw and others, 1987).

\section{HYDROGEOLOGIC CHARACTERISTICS AT THE SELECTED SITES}

Lithology, fracture characteristics, and ground-water quality at the selected sites are summarized in this section. Types of radioactive lithologies encountered in the study area are described, and results of gamma-spectral analyses (app. B-2) and whole-rock geochemical analyses (app. B-1) in rock samples are summarized. Fracture characteristics described include the frequency of fractures per 5-ft interval, the variation in frequency with depth, whether the fractures are sealed or open, orientation, types of fracture-coating minerals, and variations in the presence of these minerals with depth (tables D-1, D-3 to D-6; plates 2, 4, and 6). Results of waterquality analysis of samples from 8 of the 11 boreholes and wells and from 3 additional, adjacent wells are summarized (app. C). Detailed information on lithology, fracture characteristics, and ground-water quality for each borehole at each site is presented in appendix D.

\section{Lithology and Fracture Characteristics}

The rocks penetrated by the 11 boreholes and wells are composed primarily of three lithologic types--the arkosic sandstones of the Stockton Formation, the black mudstones of the lower part of the Passaic Formation, and the red mudstones of the lower part of the Passaic Formation. The distribution of uraniferous zones within these rocks ultimately controls the presence of radionuclides in local ground water. In the Stockton Formation, these radioactive zones are found in styolite-laced coarse basal sandstones and conglomerates. In the lower part of the Passaic Formation, the alternating black and white calcareous siltstones and mudstones (sites 3, 4, and 5) and, far less commonly, massive black mudstones, bleached gray mudstones, and coarse sandstones within red mudstone sequences contain the greatest levels of radioactivity.

The concentration of equivalent uranium in typical black and red mudstones at the study sites ranged from less than 2 to $13 \mathrm{ppm}$, and equivalent thorium concentrations ranged from 5 to $16 \mathrm{ppm}$ (app. B-2). Ratios of thorium concentration to uranium concentration werc slightly higher in the typical red mudstone from borehole 23-1076 than in the typical black and gray mudstone penetrated by the same borehole, indicating that even in typical strata, uranium concentrations in black mudstones are enriched relative to those in red mudstone. The maximum equivalent uranium concentration determined in the laboratory by gamma-ray spectrometry, 1,740 ppm, was in a whole-rock sample of black mudstone from the lower part of the Passaic Formation that emitted 7,000 cps (counts per second) of gamma radiation from $\mathrm{U}, \mathrm{Th}$, and ${ }^{40} \mathrm{~K}$ (sample 5- 8, borehole 23-1076 (app. B-2)). The concentration of cquivalent thorium in this sample was less than $5 \mathrm{ppm}(9 \mu \mathrm{g} / \mathrm{g}$ determined by ICP-AES), indicating a uranium enrichment of nearly a thousand-fold. 
The concentration of equivalent uranium in a typical arkose ranged from 2 to $8 \mathrm{ppm}$ with the exception of sample 1-3 (23 ppm) (app. B-2). Equivalent thorium concentrations ranged from less than 5 to $37 \mathrm{ppm}$. Ratios of thorium concentrations to uranium concentrations varied in the typical arkose penetrated by borehole 23-932, but were lower than the ratio of about 4.0 that is typical for sandstones, indicating slight uranium enrichment relative to thorium even in samples of arkose containing background concentrations of radioactivity. The concentrations of uranium and thorium in a slightly radioactive whole-rock arkose sample from borehole 23-932 (sample 37) were $15 \mathrm{ppm}$ and less than $20 \mathrm{ppm}$, respectively, indicating a uranium enrichment of more than three-fold. Measured gamma counts in the most radioactive arkose from borehole 21-359 were at least an order of magnitude higher than those recorded in rock from borehole 23-932 at the depth from which sample 1-7 was collected, indicating that uranium concentrations in the most radioactive arkosic strata in borehole 21-359 also may be an order of magnitude higher than those in the strata for which concentrations of radioisotopes were determined in the laboratory. Uranium and thorium content of the most radioactive arkosic strata in borehole 21-359 was not determined, however.

Concentrations of calcium and inorganic carbon are higher in rocks in the lower part of the Passaic Formation than in rocks in the Stockton Formation (app. B-1). This result is consistent with the large amount of secondary calcite in the rock matrix in the lower part of the Passaic Formation. Organic carbon also is an important component of the black mudstones from the lower part of the Passaic Formation.

Concentrations of the trace element strontium are higher in rocks and water in the lower part of the Passaic Formation than in rocks and water in the Stockton Formation (app. B-1, app. C), indicating that the concentration of this element in the water is controlled by its abundance in the strata. The high strontium content of whole-rock samples from the lower part of the Passaic Formation is related to the high calcite content of the rock (fracture coatings, calcite speckling as a result of void fillings) (pls. 3 and 5), as strontium is present in high concentrations in typical calcite. Concentrations of barium in whole-rock samples from the Stockton and Passaic Formations are similar.

The range of iron concentrations in the whole-rock samples is from 0.9 to 5.8 percent. Iron concentrations are highest in whole-rock samples from the pyriferous black mudstones in the lower part of the Passaic Formation (app. B-1) and in highly weathered shallow iron-hydroxide stained whole-rock samples from both the Passaic and Stockton Formations. Concentrations of manganese were much higher in whole-rock samples from the black mudstones of the lower part of the Passaic Formation (maximum 1,640 $\mu \mathrm{g} / \mathrm{g}$ ) than in whole-rock samples from sandstones of the Stockton Formation (maximum $403 \mu \mathrm{g} / \mathrm{g}$ ). Manganese is a common minor element in carbonate minerals and several iron-bearing minerals. Iron is a major element in many minerals found in all types of sediment from the Newark Basin, including pyrite, chlorite, biotite, magnetite, and hematite, and is a trace component in both carbonate and clay minerals. Pyritc was abundant in the strata penetrated by borehole 23-1076; the whole-rock samples from this borehole contained the most iron of the boreholes sampled.

The concentration of lithium was higher in whole-rock samples from the mudstones in the lower part of the Passaic Formation than in those from the Stockton Formation. Dean (1988, p. 84) reported the presence of lithium in high concentrations in trioctohedral illite-smectite clay 
minerals in mudstone of the Passaic Formation. Concentrations of the trace elements uranium, arsenic, cobalt, lead, molybdenum, nickel, zinc, and aluminum were higher in black mudstones from the lower part of the Passaic Formation than in arkosic sandstones from the Stockton Formation (app. B-1). The concentration of vanadium in the whole-rock samples correlates strongly to the concentration of uranium, which correlates strongly to the concentration of organic carbon (fig. 7).

The presence of iron hydroxides as fracture-coating minerals extends to greater depths in both the arkoses of the Stockton Formation (it is a dominant fracture-coating mineral to a depth of about $120 \mathrm{ft}$ in two of the three boreholes) and the red mudstones of the lower part of the Passaic Formation (it is dominant at variable depths, as much as $175 \mathrm{ft}$ below land surface in one of the borcholes) than in the black mudstones of the lower part of the Passaic Formation, where iron hydroxide is found only to depths of $40 \mathrm{ft}$ or less in three of the five borcholes. The first occurrence of pyrite as a fracture-coating mincral is found at greater depths in the arkoses of the Stockton Formation (where pyrite is present, minor amounts are found at depths of $120 \mathrm{ft}$ or more) than in the black mudstones of the lower part of the Passaic Formation (where pyrite is commonly found at depths as shallow as $45 \mathrm{ft}$ in four of the five borcholes). In general, pyrite was not found in the red mudstones of the lower part of the Passaic Formation (except adjacent to black mudstone at sites 3 and 5).

The results of the statistical analysis of the relation of fracture distribution to depth and rock type are summarized in table 2 . Median fracture density per 5-ft interval increased from the gradational conglomerate and coarse sandstone to mudstone of the Stockton Formation (sites 1 and 2) to the red mudstone of the Passaic Formation (site 6) and was greatest in the black and red mudstone of the Passaic Formation (sites 3, 4, and 5).

The results of statistical analysis of the number of fractures per 5-ft core interval for all rock types indicate that the data distribution is skewed to the left. The upper value of the number of fractures in the third quartile (8) is less than one-half the maximum value for total number of fractures (32). This fracture-frequency distribution indicates that most of the fractures are found in a few of the 5 -ft intervals. The section of core from 10 to $129 \mathrm{ft}$ below land surface is the most fractured section of the core at each site. Most of the 5-ft intervals in this section are moderately to highly fractured (table 2). Examination of the remaining sections in table $2 \mathrm{C}$ indicates many fewer fractures from 100 to $199 \mathrm{ft}$ than from 0 to $129 \mathrm{ft}$ and, in general, only sparse fracturing below $200 \mathrm{ft}$.

The distributions of vertical or high-angle and horizontal or low-angle fractures also are skewed to the left. Horizontal or low-angle fractures outnumber vertical or high-angle fractures, especially at shallow depths, except in the black mudstones, where vertical or high-angle fractures outnumber horizontal or low-angle fractures in the 10-to-129-ft section (tables 2, D-4, and D-5). The difference in frequency distribution between vertical or high-angle and horizontal or lowangle fractures is insignificant below $200 \mathrm{ft}$ because the total number of fractures is small. 

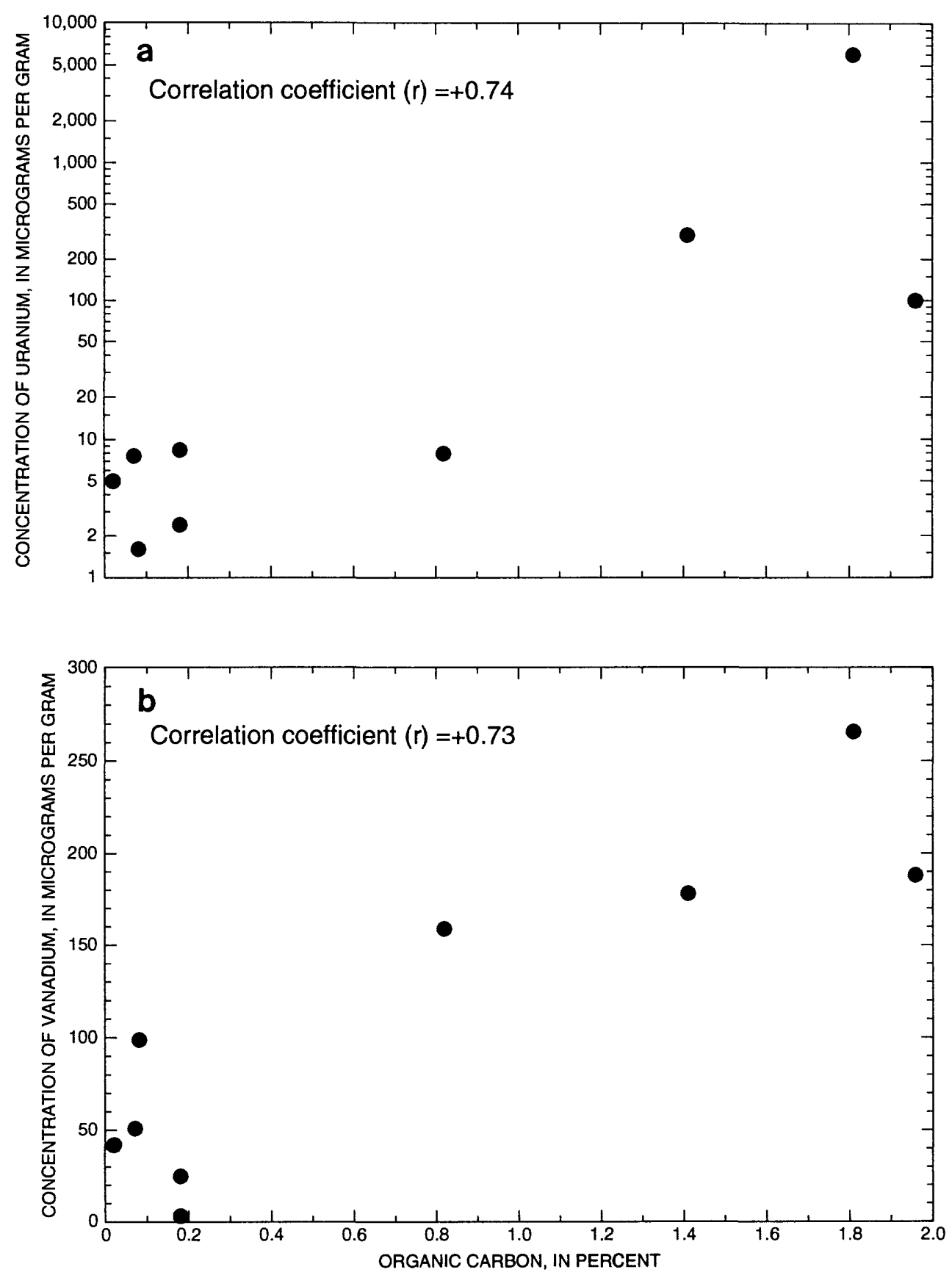

Figure 7. Relation of percentage of organic carbon to concentrations of (a) uranium and (b) vanadium in whole-rock samples from selected sites, Stockton Formation and lower part of the Passaic Formation, Newark Basin, New Jersey. 
Table 2. Distribution of number of fractures by orientation, depth, and rock type in cores from the Stockton Formation and lower part of the Passaic Formation, Newark Basin, New Jersey: (A) Number of fractures in cores from all rock types; (B) Number of fractures in cores from 10 feet to 129 feet below land surface from all rock types by orientation; (C) Number of fractures in cores from all rock types, by orientation and depth below land surface; and (D) Number of fractures in cores by orientation and rock type

[Horizontal denotes fractures dipping less than $45^{\circ}$; vertical denotes fractures dipping $45^{\circ}$ or more]

\section{A. Number of fractures in cores from all rock types}

$\frac{25 \text { th percentile }}{2} \quad \frac{50 \text { th percentile }}{5} \quad \frac{75 \text { th percentile }}{8} \quad \frac{\text { Maximum }}{32}$

\section{B. Number of fractures in cores from 10 feet to 129 feet below land surface from all rock types by orientation}

\begin{tabular}{|c|c|c|c|c|}
\hline Orientation & 25th percentile & $\underline{50 \text { th percentile }}$ & $\underline{75 \text { th percentile }}$ & $\underline{\text { Maximum }}$ \\
\hline Vertical & 1 & 1 & 3 & 20 \\
\hline Horizontal & 2 & 7 & 10 & 32 \\
\hline Total & 4 & 7 & 10 & 32 \\
\hline
\end{tabular}

\section{Number of fractures in cores from all rock types, by orientation and depth}

\begin{tabular}{|c|c|c|c|c|}
\hline Orientation & $\underline{25 \text { th percentile }}$ & $\frac{\text { 50th percentile }}{10 \text { to } 99 \text { feet }}$ & 75 th percentile & Maximum \\
\hline Vertical & 1 & 2 & 3 & 20 \\
\hline \multirow[t]{2}{*}{ Horizontal } & 3 & 5 & 9 & 26 \\
\hline & & $\underline{100 \text { to } 199 \text { feet }}$ & & \\
\hline Vertical & 0 & 1 & 2 & 8 \\
\hline \multirow[t]{2}{*}{ Horizontal } & 1 & 2 & 5 & 20 \\
\hline & & 200 to 299 feet & & \\
\hline Vertical & 0 & 1 & 4 & 14 \\
\hline \multirow[t]{2}{*}{ Horizontal } & 1 & 1 & 4 & 14 \\
\hline & & $\underline{330 \text { to } 399 \text { feet }}$ & & \\
\hline Vertical & 0 & 1 & 3 & 8 \\
\hline Horizontal & 0 & 1 & 2 & 8 \\
\hline
\end{tabular}

\section{Number of fractures in cores by orientation and rock type}

Orientation

Horizontal

Total

Vertical

Horizontal

Total

Vertical

Horizontal

Total

\section{$\frac{25 \text { th percentile }}{\text { 50th percentile }} \quad \underline{75 \text { th pe }}$}

$\begin{array}{llll}0 & 1 & 2 & 16\end{array}$

$\begin{array}{llll}0 & 1 & 4 & 20\end{array}$

$\begin{array}{llll}1 & 2 & 5 & 22\end{array}$

Black mudstone (lowest part of Passaic Formation)

$\begin{array}{rrrr}1 & 2 & 4 & 20 \\ 1 & 3 & 6 & 19 \\ 3 & 6 & 10 & 32\end{array}$

Red mudstone (lower to middle part of Passaic Formation)

\begin{tabular}{rrrr}
1 & 1 & 2 & 5 \\
2 & 4 & 7 & 26 \\
3 & 5 & 8 & 27 \\
\hline
\end{tabular}


The fracture-orientation data collected from the boreholes and wells indicate that the quantity of water that can be pumped is related to the ratio of horizontal to vertical fracturing in the surrounding rocks. About 40 percent of the fractures intercepted by well 21-358, from which yield was high, are horizontal, whereas only about 27 percent of the fractures are vertical or dip at an angle greater than 60 degrees (table D-1). Fifty percent of the fractures intersected by borehole 23-1076, another high-yield well, are horizontal, whereas only 14 percent are vertical or dip at an angle greater than 60 degrees (table D-6). In contrast, 60 percent of the fractures intersected by well 19-251, which has virtually no capacity to produce water, are vertical or dip at angle greater than 60 degrees. Only 26 percent of the fractures in this well are horizontal, and no fractures were found to dip from 1 to 30 degrees (table D-4).

Most of the non-bedding-plane fracture orientations observed with the BHTV are recognizable as the regional sets of fractures identified by Rima and others (1962), Vecchioli and others (1969), and Houghton (1990). Moderately to steeply dipping fractures oriented nearly parallel to strike (about 30 to 60 degrees) were predominant in the lower part of the Passaic Formation in strata intercepted by wells at site 4 (tables D-4 and D-5) and were abundant, though not predominant in strata of the Stockton Formation intercepted by well 21-358 at site 2 (table D-1), as would be expected on the basis of the reported abundance of this fracture set in all the rock types (Rima and others, 1962; Vecchioli and others, 1969). This fracture set is clearly absent only at site 3 (table D-3).

A set of moderately to steeply dipping fractures oriented nearly perpendicular to bedding strike are predominant in the Stockton Formation at site 2; this fracture set is the most common in the Stockton Formation in southeastern Pennsylvania (Rima and others, 1962). A third set of fractures trending north-northwest in the Stockton Formation at site 2 likely correspond to the northwest-trending fracture set identified by Rima and others (1962). In well 21-358, one of the three of these fracture sets appear in each of the assumed major zones of water production (55 to $60 \mathrm{ft}, 90$ to $110 \mathrm{ft}, 140$ to $150 \mathrm{ft}$, and 188 to $195 \mathrm{ft}$ ) (table D-1).

A second fracture set at site 4, present in strata of the lower part of the Passaic Formation intercepted by wells 19-250 and 19-251 trend nearly east-west and dip towards the north. Fractures with this orientation are not nearly as common as fractures that trend nearly parallel to strike, but at least one such fracture appears in at least one assumed water producing zone in each of the two wells (table D-4 and D-5). This fracture set was not correlated to regional fracture sets described by Vecchioli and others (1969) or by Houghton (1980). The two dominant trends of fractures in strata of the lower part of the Passaic Formation intercepted by well 21-290 at site 3 are nearly east-west and nearly north-south (table D-3); these fractures also could not be correlated to the regional fracture pattern. Strata at site 5 contain mostly horizontal or low-angle fractures; the orientation of the low-angle fractures is random (table D-6).

In well 21-358 at site 2, completed in the Stockton Formation, water-bearing fractures are common. The highest flow rate measured by using the HPFM were in sections of strata between 119 to $148 \mathrm{ft}$. Fractures were predominantly oriented parallel to, or nearly parallel to, the dip angle of the bedding plane $\left(<20^{\circ}\right.$ ) (table D-1, pl. 2). A large vertical fracture between 104 and $109 \mathrm{ft}$ is in a zone where a decrease in the rate of flow occurs (relative to the next deepest measurement of flow rate); this result indicates that the vertical fracture may also be a significant conduit for flow and may serve as the interconnection for water circulating above and below this 
depth interval. The section of strata from 90 to $100 \mathrm{ft}$ (above the vertical fracture) contains a complex network of horizontal, low-angle and high-angle fractures and may be a conductive zone. The deepest apparent zone of flow in the well, from 188 to $195 \mathrm{ft}$, contains interconnected moderately dipping fractures (table D-1). The boreholes and wells in the Stockton Formation can sustain a moderate rate of flow with little drawdown during pumping. These yield characteristics are evidence of a well-connected regional flow system, where both horizontally and moderately dipping fractures are conduits for flow. The orientations of these fractures are aligned with that of known regional fracture sets.

The dominant water-bearing sections of strata intersected by well 19-251 at site 4, which is completed in the black mudstones of the lower part of the Passaic Formation, are characterized by abundant high-angle and vertical fractures, as determined from the HPFM and BHTV logs (table D-4, pl. 4). The boreholes and wells completed at site 4 yielded little water. High-angle fractures in the black mudstones (especially those penetrated by well 19-251) most likely form small, localized, poorly connected flow systems. Significant flow is recorded from the horizontal fractures in the interval from 120 to $125 \mathrm{ft}$ in well 19-250 (table D-5). The yield from well 19-250 is much higher than that from well 19-251, indicating the importance of bedding plane fractures as conduits of water. Even in well 19-251, some production of water is from the sparse horizontal fractures from the section between 50 and $60 \mathrm{ft}$ (table D-4).

The differences observed in this study in water-yielding characteristics among the lithologies indicate that the orientation and interconnectedness of the fractures have a greater effect on well yield than does the number of fractures; wells at site 4 contain the most fractures but have the lowest well yields. Michalski (1990) hypothesizes that the dominant water-bearing fractures in the red mudstones of the Newark Basin are nearly horizontal bedding-plane fractures connected by high-angle fractures along regional fracturing patterns. Data from borehole 23-1076 at site 5 appear to be consistent with this model, as this borehole had a significant yield, and adjacent well 23-1083 contained predominantly horizontal (bedding plane) fractures (table D-5).

\section{Ground-Water Quality}

Samples of water were collected from 8 of the 11 boreholes and wells soon after they were drilled in order to characterize water quality. Although boreholes 21-290 (site 3) and 23-932 (site 1) were sealed immediately after drilling was completed, adjacent wells 21-289 (site 3) and 23801 (site 1), open at about the same depth as the sealed boreholes, were sampled to represent water quality at these sites, for a total of 10 samples. The irrigation well adjacent to borehole 231076 also was sampled after the borehole was sealed to determine the concentration of ${ }^{222} \mathrm{Rn}$, but is otherwise not included in further discussion of results of chemical analysis, as the water quality was similar to that in borehole 23-1076. Borehole 21-359 (site 2) was blocked by an obstruction, and the adjacent well 21-383 could not be sampled because of construction at the site. Results of chemical analyses of water from each sampled borehole and well are listed in appendix $C$. Concentrations of ${ }^{234} \mathrm{U},{ }^{235} \mathrm{U},{ }^{238} \mathrm{U},{ }^{226} \mathrm{Ra},{ }^{228} \mathrm{Ra}$, and ${ }^{222} \mathrm{Rn}$, and the activity of gross alpha particles and gross beta particles measured in water samples collected from each borehole also are listed in appendix C. 
Of the major cations, concentrations of calcium and sodium ranged most widely (from 44 to $110 \mathrm{mg} / \mathrm{L}$, and 9.7 to $87 \mathrm{mg} / \mathrm{L}$, respectively); concentration ranges were narrowest for magnesium and potassium. Of the major anions, concentrations of bicarbonate and chloride ranged most widely (from 76 to $236 \mathrm{mg} / \mathrm{L}$ and 11 to $230 \mathrm{mg} / \mathrm{L}$, respectively); concentration ranges were intermediate for sulfate and narrowest for nitrate and fluoride.

Stiff diagrams (fig. 8) indicate that calcium and bicarbonate were the dominant cation and anion, respectively, in 8 of the 10 water samples; chloride was the dominant anion in the remaining 2 samples (wells 21-358 and 19-249), but bicarbonate also was abundant. Concentrations of magnesium and sulfate were consistently low in relation to concentrations of the other major constituents in all the samples. The shapes of the Stiff diagrams are similar for all the water samples in which calcium and bicarbonate are the predominant ions. The size of the Stiff diagrams represents the amount of dissolved mineral matter in the water; therefore, the largest diagrams (wells 23-1076 and 3-287) indicate longer periods of interaction between water and the rock or a greater abundance of soluble calcite in the rock matrix than the smaller diagrams.

The two wells from which water contained the greatest concentrations of sodium and chloride (21-358 and 19-249) are adjacent to major roadways. The dominant source of sodium and chloride to the shallow water intercepted by these wells probably is road salt. Concentrations of sodium and chloride also were greater than background levels in the other boreholes and wells near major roadways (borehole 23-1076) or located in urban centers (wells 03-286 and 03-287), indicating that road salt is the likely source of these constituents.

Of the trace elements measured, strontium and barium were present in ground water in the greatest concentrations. The concentration of strontium exceeded $100 \mu \mathrm{g} / \mathrm{L}$ in water samples from all 10 boreholes and wells, whereas the concentration of barium exceeded $100 \mu \mathrm{g} / \mathrm{L}$ in water from 7 of the borcholes and wells. Water from borcholes in the interbedded red, gray, and black mudstone in the lower part of the Passaic Formation contained the highest concentrations of strontium (maximum concentration $590 \mu \mathrm{g} / \mathrm{L}$ in the sample from borehole 23-1076). Concentrations of barium were relatively uniform in water from all three rock types. The distribution pattern in water relative to rock type for strontium is similar to the pattern of strontium concentrations observed in whole-rock samples.

Iron and manganese were detected in low concentrations in most of the water samples; however, the concentrations of those elements increased by several orders of magnitude in the absence of dissolved oxygen. The maximum concentrations of iron and manganese--1,300 and $660 \mu \mathrm{g} / \mathrm{L}$, respectively-- were measured in water from borehole 23-1076, which contained the lowest concentration of dissolved oxygen of the 10 samples collected.

Lithium was detected in water from all 10 boreholes and wells. Concentrations of lithium were higher in water samples from the five boreholes and wells (sites 3,4, and 5) completed in the black and red mudstones in the lower part of the Passaic Formation than in water samples from boreholes and wells completed in other lithologies. Lithium is present in high concentrations in black mudstone (app. B-1). 

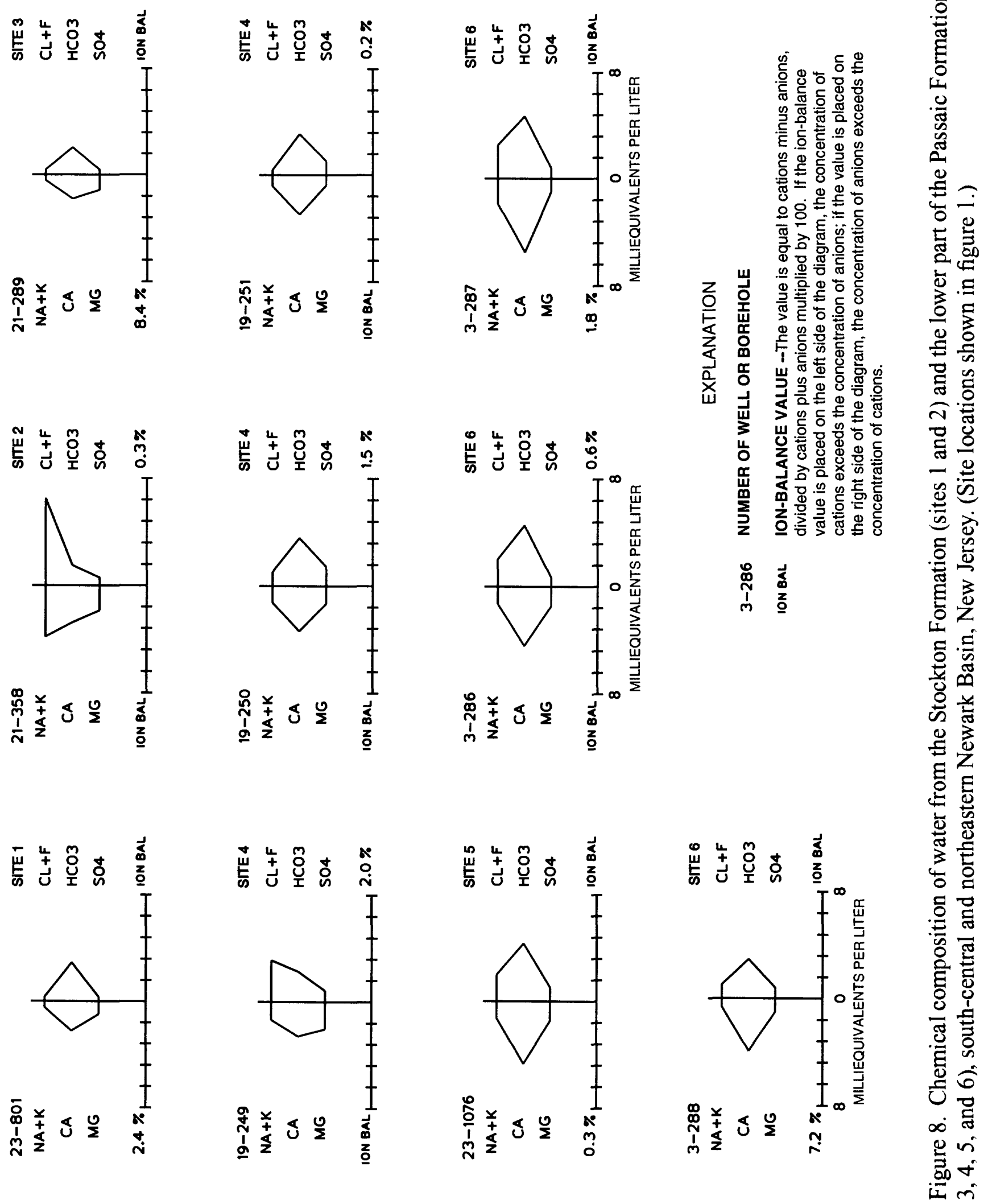
Beryllium, chromium, cobalt, copper, silver, and vanadium were not detected in any of the 10 water samples. Concentrations of arsenic, cadmium, lead, molybdenum, nickel, zinc, and aluminum were below the minimum reporting limit (MRL) in most samples (app. C), but were at or barely above the MRL in water samples from wells 19-249, 19-250, and 19-251 at site 4, which are completed in black mudstones of the lower part of the Passaic Formation. The trace elements detected in the water samples tended to be present in greater concentrations in the whole-rock samples of black mudstone than the trace elements that were not detected in the water samples (app. B-1).

Gross alpha-particle activities in all of the water samples ranged from less than 1.0 to $66.4 \mathrm{pCi} / \mathrm{L}$. The maximum activity was measured in water from borehole 23-1076 (app. C), which was completed in interbedded red and black mudstone in the lower part of the Passaic Formation. Gross alpha-particle activities in water from 4 of the 10 boreholes and wells exceeded $15 \mathrm{pCi} / \mathrm{L}$, the drinking-water standard set by the USEPA (U.S. Environmental Protection Agency, 1994), indicating that elcvated concentrations of the alpha-particle-emitting isotopes of uranium and ${ }^{226} \mathrm{Ra}$ probably are present in the water from these wells.

Gross beta-particle activities in the 10 water samples ranged from 3.5 to $25 \mathrm{pCi} / \mathrm{L}$ (app. C). The maximum value was measured in water from borehole 23-1076. Gross beta-particle activities in water samples from 3 of the 10 borcholes and wells exceeded $15 \mathrm{pCi} / \mathrm{L}$; gross alphaparticle activities in all 3 of these water samples also were greater than $15 \mathrm{pCi} / \mathrm{L}$. The maximum potassium concentration in the 10 samples was $10 \mathrm{mg} / \mathrm{L}$ in water from borehole 19-250, which was completed in gray and black mudstones in the lower part of the Passaic Formation. The beta activity in water containing $10 \mathrm{mg} / \mathrm{L}$ of potassium, calculated by using the formula of Schleien and Terpilak (1984), is $8.1 \mathrm{pCi} / \mathrm{L}$. The total gross beta-particle activity of the sample was $17 \mathrm{pCi} / \mathrm{L}$; therefore, the gross beta-particle activity resulting from the presence of ${ }^{40} \mathrm{~K}$ accounts for slightly less than one-half of the total. The concentration of potassium in water samples from 8 of the 10 boreholes and wells was less than $3 \mathrm{mg} / \mathrm{L}$, indicating that only a small part of the gross beta-particle activity in the water is the result of ${ }^{40} \mathrm{~K}$ decay. Typically, the proportion of gross beta-particle activity resulting from ${ }^{40} \mathrm{~K}$ decreases as gross beta-particle activity increases. Therefore, in water samples from these boreholes and wells that have high gross beta-particle activities, most of the gross beta-particle activity must result from the disintegration of radionuclides from the decay series of isotopes of uranium or thorium. The close correlation between alpha-particle activities and beta-particle activities also indicates that the beta-particle-emitting radionuclides from the ${ }^{238} \mathrm{U},{ }^{232} \mathrm{Th}$, or ${ }^{235} \mathrm{U}$ decay series may be the source of much of the betaparticles in the water from these wells. Some researchers have contended, however, that these beta-particle-emitting radionuclides ingrow into the sample between the time of sample collection and the time of sample analysis and are not representative of the beta-particle activity of the ground water in the environment (Welch and others, 1995).

The sum of uranium-isotope ${ }^{234} \mathrm{U},{ }^{235} \mathrm{U}$, and ${ }^{238} \mathrm{U}$ ) activitics ranged from less than 0.1 to $18.1 \mathrm{pCi} / \mathrm{L}$; the maximum uranium-isotope activity was measured in the water sample from well 19-250. Water from well 23-801 contained no detectable uranium. Water from the eight remaining boreholes and wells contained from 0.9 to $6.4 \mathrm{pCi} / \mathrm{L}$ of total uranium-isotope activity. The activity of ${ }^{235} \mathrm{U}$ is not considered further in this report because it is insignificant relative to the activity of the other two uranium isotopes (Faure, 1977). 
The ratio of ${ }^{234} \mathrm{U}$-isotope activity to ${ }^{238} \mathrm{U}$-isotope activity in the 10 water samples ranged from 1.24 to 2.38; the maximum ratio was measured in water collected from well 19-251. The ${ }^{234} \mathrm{U} /{ }^{238} \mathrm{U}$-isotope activity ratio equaled or exceeded 2.0 in water samples from four of the eight boreholes for which this ratio was determined. The radioactivity of dissolved uranium in water from rocks in uraniferous areas of the Newark Basin is greatly underestimated when only the mass of dissolved uranium is determined because this measured mass conventionally is converted to an assumed uranium activity on the basis of the concept of secular equilibrium, in which the ${ }^{234} \mathrm{U} /{ }^{238} \mathrm{U}$-isotope activity ratio is equal to 1 . Slightly elevated (greater than 1 ) ${ }^{234} \mathrm{U} /{ }^{238} \mathrm{U}$-isotope activity ratios in ground water that contains abundant dissolved uranium are typical in oxidizing systems where uranium is leached from rock strata (Osmond and Cowart, 1976), such as the ground-water system of the Newark Basin (Szabo and Zapecza, 1987).

${ }^{226} \mathrm{Ra}$ activities in the 10 water samples ranged from less than 0.6 to $22.5 \mathrm{pCi} / \mathrm{L}$. Maximum activity, measured in water from borehole $23-1076$, exceeded $5.0 \mathrm{pCi} / \mathrm{L}$, the USEPA MCL (U.S. Environmental Protection Agency, 1994). The maximum gross alpha-particle and gross beta-particle activities also were measured in the water sample from this borehole. Samples from two additional wells contained activities of ${ }^{226} \mathrm{Ra}$ that excceded $3.0 \mathrm{pCi} / \mathrm{L}$ (app. C). Watcr samples containing less than $0.6 \mathrm{pCi} / \mathrm{L}$ of ${ }^{226} \mathrm{Ra}$ from several of the boreholes and wells also contained activities of uranium-isotopes greater than $1.0 \mathrm{pCi} / \mathrm{L}$. These boreholes intersected radioactive strata, indicating that despite the presence of radioactive strata, radium solubility is limited in most of the ground water in the Newark Basin, and dissolved ${ }^{226} \mathrm{Ra}$ commonly tends to be less than that of ${ }^{238} \mathrm{U}$, the parent material.

${ }^{228} \mathrm{Ra}$ activities in the 10 water samples ranged from less than 1.0 to $3.4 \mathrm{pCi} / \mathrm{L}$. The maximum activity of this isotope also was measured in water collected from borehole 23-1076. Water from 7 of the 10 boreholes and wells contained ${ }^{228} \mathrm{Ra}$ activities less than $1.0 \mathrm{pCi} / \mathrm{L}$. The activity of ${ }^{226} \mathrm{Ra}$ was greater than that of ${ }^{228} \mathrm{Ra}$ in water samples from the four boreholes and wells in which the activities could be compared. The maximum ${ }^{226} \mathrm{Ra}$-to- ${ }^{228} \mathrm{Ra}$ activity ratio (6.58) was determined for well 23-1076. Results of chemical and gamma-spectral analysis of the cores from three sites indicated that some or all of the rock strata are strongly enriched in uranium relative to thorium (the uranium/thorium ratio is greater than 1,000 in some strata penetrated by borehole 23-1076 (app. B-2)). Because ${ }^{238} U$ is strongly enriched relative to ${ }^{232} \mathrm{Th}$ in the rock strata penetrated by the boreholes (app. B-2, figs. D-2 to D-5, and 10), the water that percolates through these strata is enriched in ${ }^{226} \mathrm{Ra}$ relative to ${ }^{228} \mathrm{Ra}$.

${ }^{222} \mathrm{Rn}$ activities ranged from 1,300 to $32,100 \mathrm{pCi} / \mathrm{L}$; the maximum activity was measured in water collected from well 21-358, which was completed in the arkosic sandstone of the Stockton Formation. ${ }^{222} \mathrm{Rn}$ activities in water samples from all 10 boreholes and wells from which samples were analyzed for this constituent exceeded $1,000 \mathrm{pCi} / \mathrm{L} .{ }^{222} \mathrm{Rn}$ activities in water samples from two wells exceeded $20,000 \mathrm{pCi} / \mathrm{L}$; activities in samples from two additional wells exceeded $2,000 \mathrm{pCi} / \mathrm{L}$ (app. C). 
The ratios of the activity of ${ }^{222} \mathrm{Rn}$ to that of the radioactive parent, ${ }^{226} \mathrm{Ra}$, ranged from 813 to 10,031 . Because ${ }^{222} \mathrm{Rn}$ is an inert, soluble radioactive gas with a short half-life, it can migrate only short distances from the source rocks; therefore, the activity of dissolved ${ }^{222} \mathrm{Rn}$ is a better measure of the ${ }^{226} \mathrm{Ra}$ content of the surrounding aquifer matrix than the activity of dissolved ${ }^{226} \mathrm{Ra}$ itself. The high ${ }^{222} \mathrm{Rn} /{ }^{226} \mathrm{Ra}$ activity ratios indicate that, in the uraniferous strata penetrated by the boreholes, most of the ${ }^{226} \mathrm{Ra}$ is retained in the solid phases of the aquifer matrix, whereas a significant proportion of the ${ }^{222} \mathrm{Rn}$ is in solution. The ${ }^{222} \mathrm{Rn} /{ }^{238} \mathrm{U}$ activity ratios are nearly as great as those of ${ }^{222} \mathrm{Rn} /{ }^{226} \mathrm{Ra}$, indicating that most of the uranium also is retained in the solid phases of the aquifer matrix.

\section{RELATION OF HYDROGEOLOGIC CHARACTERISTICS TO DISTRIBUTION OF RADIOACTIVITY IN GROUND WATER}

The distribution of radioactivity in ground water in the Newark Basin can be delineated on the basis of lithology, including the presence of highly radioactive strata and the continuity of radioactive lithologies within formations; the fracture characteristics, including the number, orientation, and interconnectedness of the open fractures and the amount of interaction between radioactive strata and circulating water; and the geochemistry of the water, which controls the solubility of the radionuclides. The effects of these factors on radioactivity at the selected sites are discussed below and are evaluated from a regional perspective for the Newark Basin as a whole.

\section{Selected Sites}

Results of the analytical techniques discussed above were used to describe the lithology, fracture characteristics, and geochemistry at each borehole and well site, because the presence of radioactivity in ground water at any single location depends on these factors. At each of the six sites, these factors were assessed in order to explain the presence or absence of radioactive ground water.

\section{Site 1}

A slightly anomalous radioactive zone at a depth of 104 to $106 \mathrm{ft}(\mathrm{pl} .1)$ is shown on the gamma log from borehole 23-932, completed in the Stockton Formation. Gamma-spectral analyses of whole-rock samples indicate slight enrichment of equivalent uranium (11-15 ppm) near this radioactive zone (102.0-102.6 ft) relative to other zones in the borehole and relative to thorium in this zone (app. B-2). Chemical analyses of whole-rock samples from the core itself confirm the presence of uranium (7.1 ppm) in the stratum at $102.5 \mathrm{ft}$ (app. B-1). The number of fractures from 100 to $105 \mathrm{ft}$ in the borehole is greater than that in any other interval below $75 \mathrm{ft}$ (pl. 2). A clay-bearing fissured zone also is located at a depth of 103 to $104 \mathrm{ft}$ within the 100-to105-ft interval (pl. 1). The caliper log shows an enlargement of the well diameter at approximately this depth (pl. 2). A slight decrease in resistance at 104 to $106 \mathrm{ft}$ corresponds approximately to the depth of the fissured zone and indicates that significant amount of water probably is present in this zone. The many fractures and the fissured zone could provide a conduit for water to flow through the radioactive strata, resulting in the high concentrations of gross alpha-particle activity $(18.6 \mathrm{pCi} / \mathrm{L}),{ }^{226} \mathrm{Ra}(4.81 \mathrm{pci} / \mathrm{L})$, and ${ }^{222} \mathrm{Rn}(3,910 \mathrm{pCi} / \mathrm{L})$ measured in the water sample from adjacent well 23-801. 
The absence of uranium from the water probably results from the reducing geochemical environment at the depth of the open interval. DO is virtually absent from the water $(0.3 \mathrm{mg} / \mathrm{L})$, whercas dissolved iron is present in high concentrations (app. C). In reducing waters, uranium cannot be oxidized to the soluble +6 valence state and, therefore, remains in solid phase in the aquifer matrix (Cochran and others, 1986). Radium, however, is present in high concentrations in the reducing water solution because of the absence of secondary iron hydroxides. This determination is verified by examination of fracture-surface coatings in core samples (pl. 2). The iron hydroxides are known to prevent solubilization of radium by adsorbing significant quantities of it from solution (Ames and others, 1983). Because ${ }^{222} \mathrm{Rn}$ is inert, it is soluble in both oxidizing and reducing waters. The high concentration of ${ }^{222} \mathrm{Rn}$ indicates that circulating ground water is in contact with a significant surface area in the radioactive zone, allowing efficient transfer of ${ }^{222} \mathrm{Rn}$ from the solid matrix to the circulating solution.

Gross alpha-particle activity in water from this borehole was greater than $15 \mathrm{pCi} / \mathrm{L}$ and thus exceeded the drinking-water standard (U.S. Environmental Protection Agency, 1994). Gross alpha-particle activity is not attributed to the activity of uranium because uranium was not detected in the sample. The sum of the concentration of ${ }^{226} \mathrm{Ra}$ and ${ }^{228} \mathrm{Ra}$ was greater than $5 \mathrm{pCi} / \mathrm{L}$, and therefore, also exceeded the interim drinking-water standard for radium (U.S. Environmental Protection Agency, 1994). (Modification of the radium standard has been proposed such that each radium radionuclide would be assigned an individual standard ranging from 5 to $20 \mathrm{pCi} / \mathrm{L}$ (U.S. Environmental Protection Agency, 1991). If the modification were adopted, the activity of radium in water from this borehole would not exceed the radium standard.) The concentration of ${ }^{222} \mathrm{Rn}$ exceeded all proposed standards.

\section{Site 2}

The strata penetrated by well $21-358$ and borehole $21-359$ contain many highly radioactive zones (pl. 2). Highly radioactive zones in well $21-358$ at depths of 62 and $67 \mathrm{ft}$ coincide with the top of one of the two most densely fractured sections in the core (pls. 1 and 2). Fracture density is especially high in the 5 - $\mathrm{ft}$ intervals from 65 to $75 \mathrm{ft}$ (15 and 16 fractures, respectively, in the upper and lower intervals) relative to most of the strata penetrated by this well. The heatpulse flowmeter $\log$ (HPFM) indicates significant ground-water flow under both natural and pumping conditions in the densely fractured section from about 55 to $75 \mathrm{ft}$ (fig. 9). The dense fracturing intersecting the radioactive strata at shallow depths, and the significant amount of water flow, provide optimum conditions for water-rock interaction, which causes the water to contain high concentrations of dissolved ${ }^{222} \mathrm{Rn}$ and high gross alpha-particle activities.

Water-quality data for well 21-358, including the high concentration of chloride and low concentrations of alkalinity and silica, indicate rapid circulation of water in the shallow, fractured intervals. High concentrations of chloride most likely are the result of recent percolation of contaminants resulting from human activities, such as road salt. Low concentrations of alkalinity and silica indicate a short residence time of water in the rock matrix. The high concentration of dissolved radionuclides in water of short residence time indicates that even a small amount of weathering of radioactive minerals in the rock can result in highly radioactive water.

The zone of potential water flow in the intensely fractured section at depths of 115 to $135 \mathrm{ft}(13,22,13$, and 3 fractures, respectively, per 5-ft interval, with a fissured zone at the base 
of this section) does not intersect radioactive strata and, hence, is not the source of the high concentrations of dissolved radioactivity. The nonradioactive water from this interval may dilute the overall amount of radioactivity in water from the borehole. Many highly radioactive zones also are present at a depth of $183 \mathrm{ft}$ or greater in the strata penetrated by well 21-358; however, the density of fractures and the flow of water are much smaller at these depths than at shallower depths. These data also indicate that the bulk of the radioactivity dissolved in the water samples from this well must originate from the shallower rocks.

The presence of uranium and radium, found concurrently in the water sample from well $21-358$, is not typical of ground water in the Newark Basin (Szabo and Zapecza, 1987). One explanation for this anomaly is mixing of oxidizing, uranium-bearing water with reducing, radium-bearing water from different fractured intervals in the well during sample collection. Limonite is the dominant fracture-coating mineral in shallow strata from 25 to $80 \mathrm{ft}$ and is abundant to a depth of $125 \mathrm{ft}$. The abundance of limonite indicates that to a depth of $125 \mathrm{ft}$ circulating water is highly oxidizing and, therefore, is optimal for uranium dissolution. At depths below 125 $\mathrm{ft}$, limonite is present in smaller amounts, even trace quantities, indicating that the water circulating below $125 \mathrm{ft}$ is not strongly oxidizing and, therefore, is not optimal for uranium dissolution. This anoxic ground water favors ${ }^{226} \mathrm{Ra}$ dissolution. The presence of trace quantities of pyrite (along with only trace amounts of limonite) in fractures intersecting the radioactive zone at $174 \mathrm{ft}$ indicate a decrease in the oxidizing capacity of the water at this depth relative to water from shallower depths, and thus a greater probability that any water from this zone relative to shallower depths will contain more ${ }^{226} \mathrm{Ra}$ than uranium.

Concentrations of uranium isotopes and ${ }^{226} \mathrm{Ra}$ in the sample from well 21-358 are high compared to those in water samples collected from the other boreholes and wells during this study; however, the concentration of ${ }^{222} \mathrm{Rn}$ far exceeded those measured in any of the other watcr samples. The concentration of dissolved ${ }^{222} \mathrm{Rn}$ in the water from this borehole was more than an order of magnitude greater than the concentrations in water from wells completed in less radioactive strata in the Newark Basin (Szabo and Zapecza, 1987) and exceeded all proposed standards by more than an order of magnitude. The lack of concentrations of uranium and ${ }^{226} \mathrm{Ra}$ of about the same magnitude as the concentration of ${ }^{222} \mathrm{Rn}$ in water from well $21-358$ is consistent with the chemically reactive nature of both uranium and radium and with their tendency, relative to radon, to remain in the solid phase in the aquifer matrix. Gross alpha-particle activity in the water sample from the well exceeded the drinking-water standard because the gross alpha-particle activity minus the total uranium-isotope activity was greater than $15 \mathrm{pCi} / \mathrm{L}$ (U.S. Environmental Protection Agency, 1994).

Geophysical and petrographic data from borehole 21-359 indicate that water from this borehole probably contains relatively high concentrations of radioactivity, but no sample could be collected to confirm this hypothesis. The evidence includes the presence of many radioactive zones, primarily a series of conglomeratic units from 130 to $175 \mathrm{ft}$; the presence of a limonitebearing fissured zone at $163 \mathrm{ft}$; and minor deflections in the resistance log within the radioactive zone, at $120 \mathrm{ft}$ and $150 \mathrm{ft}$ (pls. 1 and 2). Radioactive water, which could be entering the borehole from the section between 130 and $175 \mathrm{ft}$, could be diluted by less radioactive water from the highly fractured transition zone (above $100 \mathrm{ft}$ ) where the rocks are less radioactive than in the 130-to-175-ft section. 

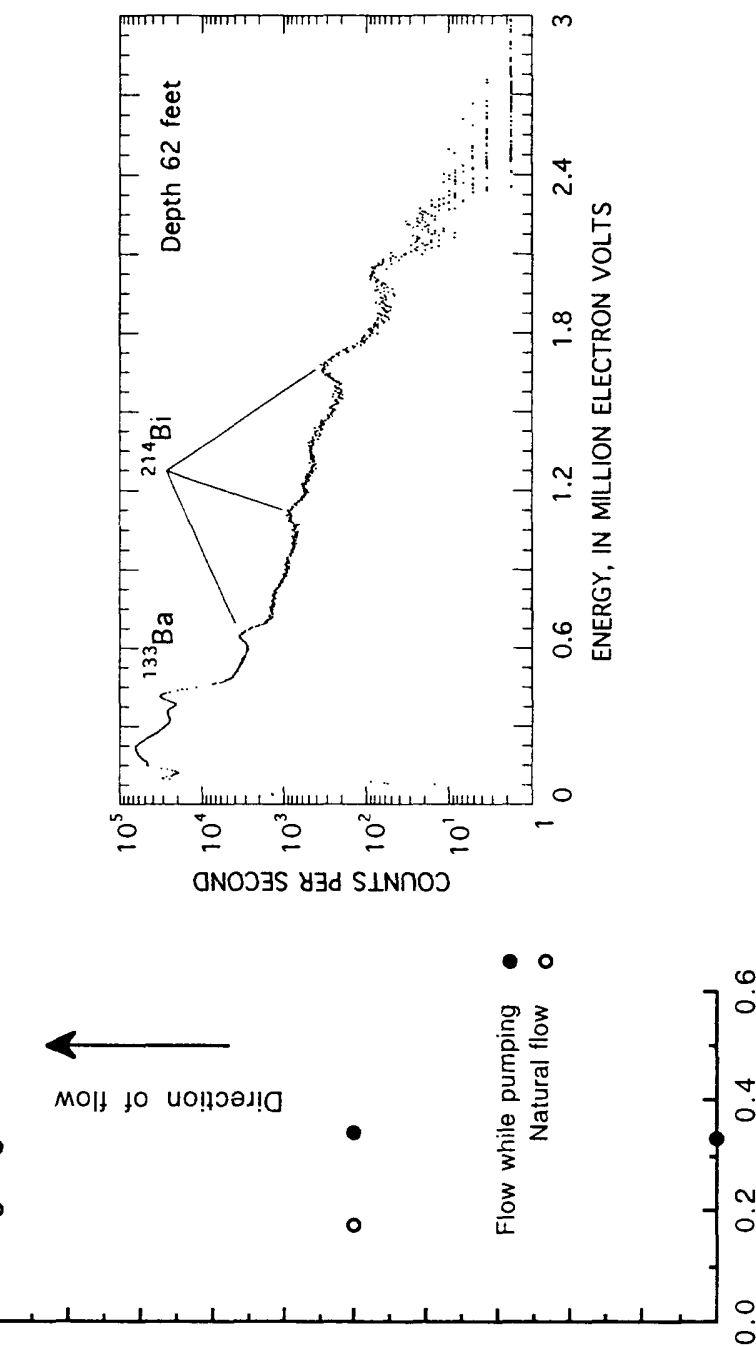

艎

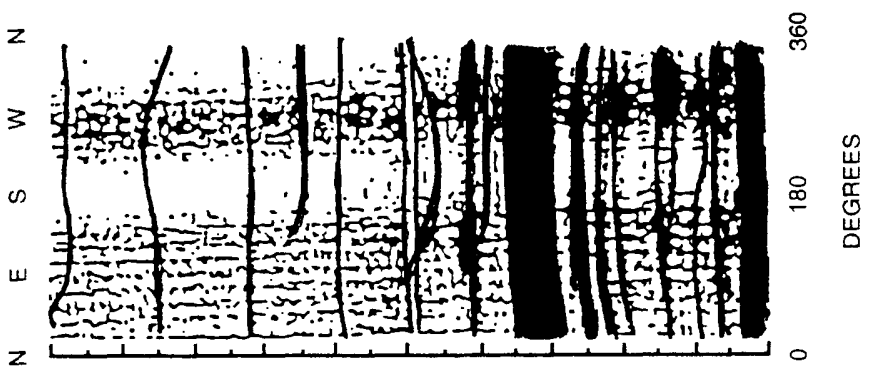

으 มี

光

可

ப.

응

율ำ

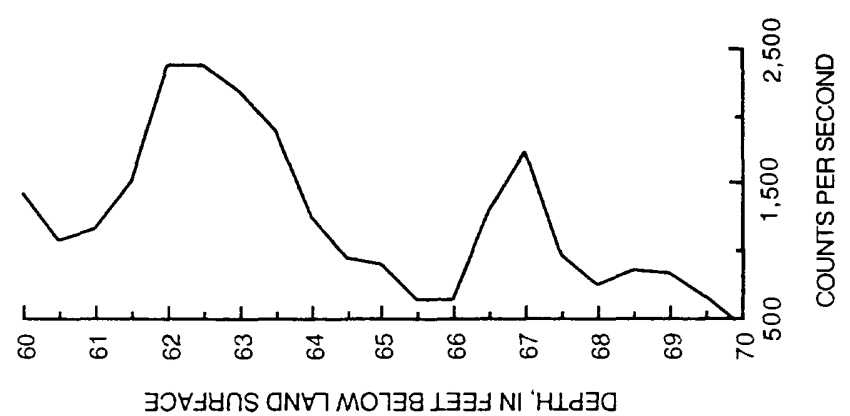




\section{Site 3}

Highly radioactive zones in borehole $21-290$ were detected at depths of $142 \mathrm{ft}$ and $175 \mathrm{ft}$ (pl. 3). The abundance of limonite, large deflections on the caliper log, and the presence of interconnected fractures imaged by the BHTV indicate that water circulates in the shallow nonradioactive section from 40 to $85 \mathrm{ft}(\mathrm{pl} .4)$. The temperature log (pl. 4) shows a major deflection at approximately $85 \mathrm{ft}$, which corresponds to a major deflection on the caliper log at this depth, and indicates presence of a significant water-bearing fracture at this depth. The decline in the number of total fractures and the number of open horizontal fractures (pl. 4) below $95 \mathrm{ft}$ indicates a probable lack of water circulation there. Furthermore, limonite is absent below $125 \mathrm{ft}$, indicating that the oxidizing water produced from this well was intercepted above $125 \mathrm{ft}$. The BHTV recorded few fractures from $125 \mathrm{ft}$ to $145 \mathrm{ft}$; many of these were found to be sealed when examined in hand specimens. Fissured zones and open vertical and horizontal fractures are abundant in the dark gray pyriferous mudstone in the section from $145 \mathrm{ft}$ to $170 \mathrm{ft}$ (pl. 4). The BHTV image shows many fractures and sharp fluctuations in the caliper logs that correspond to the many fissured zones in the intervals from 145 to $155 \mathrm{ft}$ and 160 to $170 \mathrm{ft}$. Sharp fluctuations on the spontaneouspotential and single-point-resistance logs indicate that these fissured zones may be water-bearing (pl. 4). No additional evidence exists to confirm the presence of water in these intervals, however. This densely fractured section is bounded above and below by minimally fractured sections of strata that contain the highly radioactive zones. Whether or not water is present in these fissured zones, fracturing is absent in the uranium-enriched strata at a depth of $142 \mathrm{ft}$; only a few open fractures were present in the strata adjacent to the radioactive interval at $142 \mathrm{ft}$. No open fractures intersected the radioactive stratum at $175 \mathrm{ft}(\mathrm{pl} .4)$. These fracture data indicate that the strata containing the radioactive zones are isolated from shallow circulating ground water and from any water present in the adjacent fissured zones. Hence, water from well 21-289 contains little radioactivity. The concentration of ${ }^{222} \mathrm{Rn}, 1,370 \mathrm{pCi} / \mathrm{L}$, exceeded most of the proposed drinking-water standards, however (U.S. Environmental Protection Agency, 1991).

Water-quality data also indicate that most of the water produced from well 21-289 was from shallow fracture zones. The radioactive zones are in dense black mudstones below $125 \mathrm{ft}$ where pyrite is common (pl. 3 and 4). The absence of iron hydroxide rinds on pyrite in the black mudstones and on fracture surfaces (pl. 4) indicates that circulation of oxygenated water at this depth is limited. The water sample from the borehole was oxygenated, indicating that little, if any, of the water produced from the well comes from a depth greater than $125 \mathrm{ft}$ where pyrite and, by inference, reducing water is present. Little iron or manganese is present in the water sample; the presence of these constituents in elevated concentrations is typical for reducing water. The concentration of ${ }^{226} \mathrm{Ra}$ was low because this radionuclide is relatively insoluble in oxidizing water. The uranium concentration in the sample was $1.3 \mu \mathrm{g} / \mathrm{L}$ (app. C). Uranium is soluble in the oxygenated, iron-poor, alkaline water produced from the well. The gross alpha-particle activity in the water sample from the well is derived from isotopes of uranium. The uranium present in the oxygenated water is likely derived from the leaching of small amounts of uranium from relatively uranium-poor red mudstones near land surface and not from the radioactive black mudstone. 


\section{Site 4}

The red and black mudstones penetrated by well 19-250 contain five zones in which radioactivity is elevated; these zones are found at 19, 102, 125, 392, and $409 \mathrm{ft}$ (pl. 3). Three of the radioactive zones $(19,102$, and $125 \mathrm{ft})$ coincide with or are vertically adjacent to highly fractured sections (fig. 10). These three shallow radioactive zones contain a large number of fractures, many of which are open, as indicated by the BHTV (fig. 10), and by the fracture-density count in core samples (pl. 4). Displacements on the caliper log verify the presence of open fractures at these depths.

The fissured zone in the interval from 15 to $20 \mathrm{ft}$ can act as a conduit for water movement; minute amounts of flow were indicated by the HPFM. The temperature log showed a sharp change in water temperature ( $\mathrm{pl} .4$ ) above $25 \mathrm{ft}$, which indicates that colder water from the surface, possibly from the shallow fissured zone, enters the borehole there. The fractures appear to be well-connected between 10 and $65 \mathrm{ft}$, as indicated by the many low-angle and high-angle open fractures and the abundant production of water under pumping conditions; the HPFM recorded about $0.8 \mathrm{gal} / \mathrm{min}$ of flow from the fractures between 35 and $65 \mathrm{ft}$ during pumping. Hand specimens of rock contain many etch pits in calcite to a depth of $75 \mathrm{ft}$; many open fractures to a depth of $65 \mathrm{ft}$; abundant iron hydroxides from 10 to $35 \mathrm{ft}$, especially in the fissured zone in the interval from 15 to $20 \mathrm{ft}$ (pl. 4); and fracture surfaces coated with secondary clay minerals at 35 , 70 , and $100 \mathrm{ft}$. These characteristics indicate that water circulates to depths that encompass the shallower radioactive interval at $19 \mathrm{ft}$ and possibly the one at $102 \mathrm{ft}$.

HPFM data show that water is flowing through fractures in isolated zones in the interval from 100 to $105 \mathrm{ft}$ and the section from 115 to $125 \mathrm{ft}$. Fractures at these depths are most likely poorly connected to those in the highly fractured section from 15 to $30 \mathrm{ft}$, just below land surface, but may be connected to the highly fractured section between 35 and $100 \mathrm{ft}$. Both the spontaneous-potential and the single-point-resistance logs show deflections in the intervals 100 to $105 \mathrm{ft}$ and 115 to $125 \mathrm{ft}$, indicating the possible presence of water-bearing fractures (pl. 4). The predominant major fractures at $125 \mathrm{ft}$ and $127 \mathrm{ft}$, viewed with the BHTV, appear to be parallel to the bedding (pl. 4; fig. 10). Interpretation of data from the HPFM, the BHTV, and the gamma log indicates water circulates in the 120-to-125-ft interval in the large bedding-plane fracture at $125 \mathrm{ft}$ that intersects the highly radioactive rocks (fig. 10); water may also be present in the horizontal fractures at $127 \mathrm{ft}$. The bedding-plane fracture maximizes water-rock interaction within the radioactive zone(s), resulting in highly radioactive water, as evidenced by the extremely high concentration of dissolved ${ }^{222} \mathrm{Rn}$.

The radioactive zone at $392 \mathrm{ft}$ is in sparsely fractured strata and at $409 \mathrm{ft}$ is in moderately fractured strata; spontaneous-potential and single-point-resistance logs show many deflections (312 ft and $412 \mathrm{ft}$ ), but interpretation of the spontaneous-potential and single-point-resistance logs at this site is inconclusive. The HPFM does not indicate water circulation at great depths.

Uranium and radium were found concurrently in the water sample from well 19-250--an atypical result for ground water in the Newark Basin (Szabo and Zapecza, 1987). Limonite is present as a fracture-coating material only in the shallow fissured zone in the 15-to-20-ft interval and in the interconnected fractures that extend to a depth of $35 \mathrm{ft}$, whereas pyrite and calcite are the dominant fracture-coating minerals below $95 \mathrm{ft}$, including the water-bearing fractures at $102 \mathrm{ft}$ 

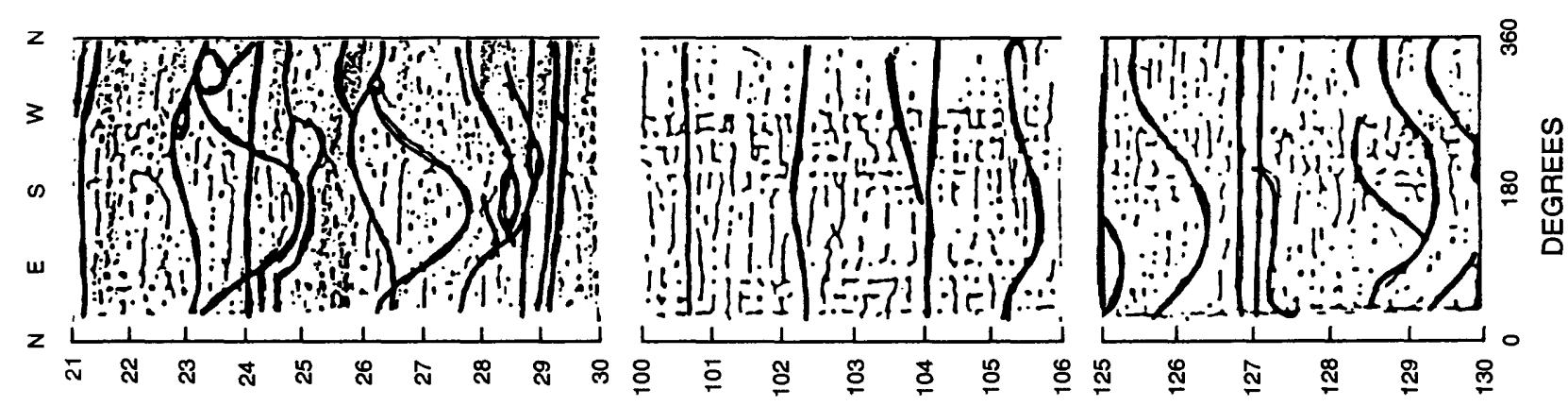

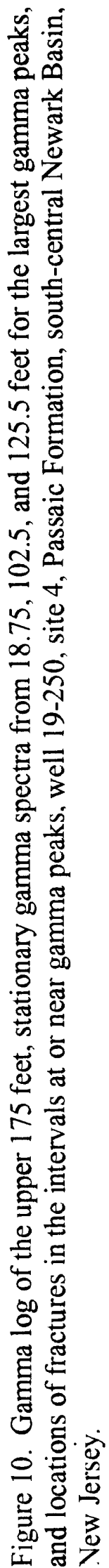

$\exists O \forall\lrcorner y \cap S$ aN $\forall 7$ MO M

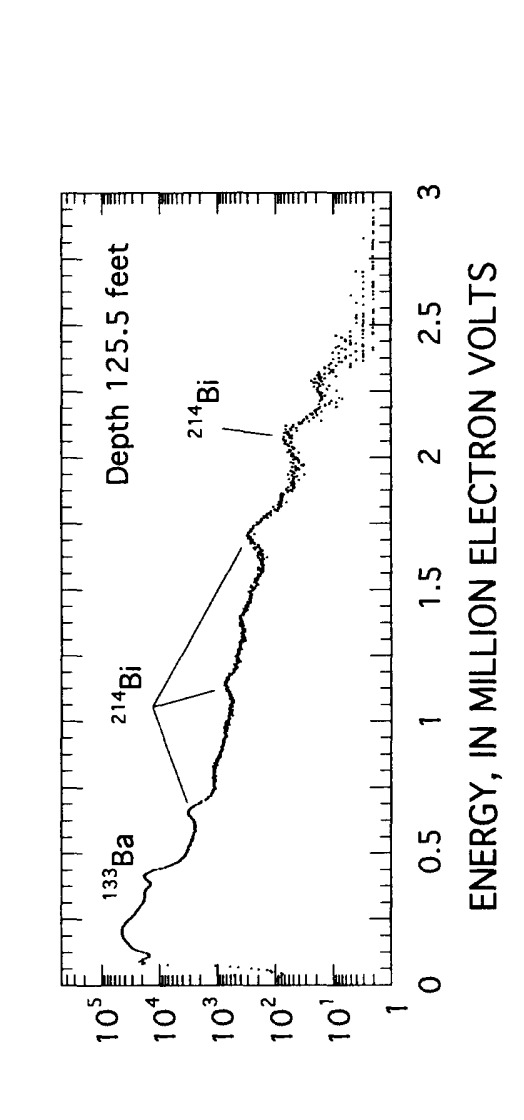

aNOJ $3 S$ y
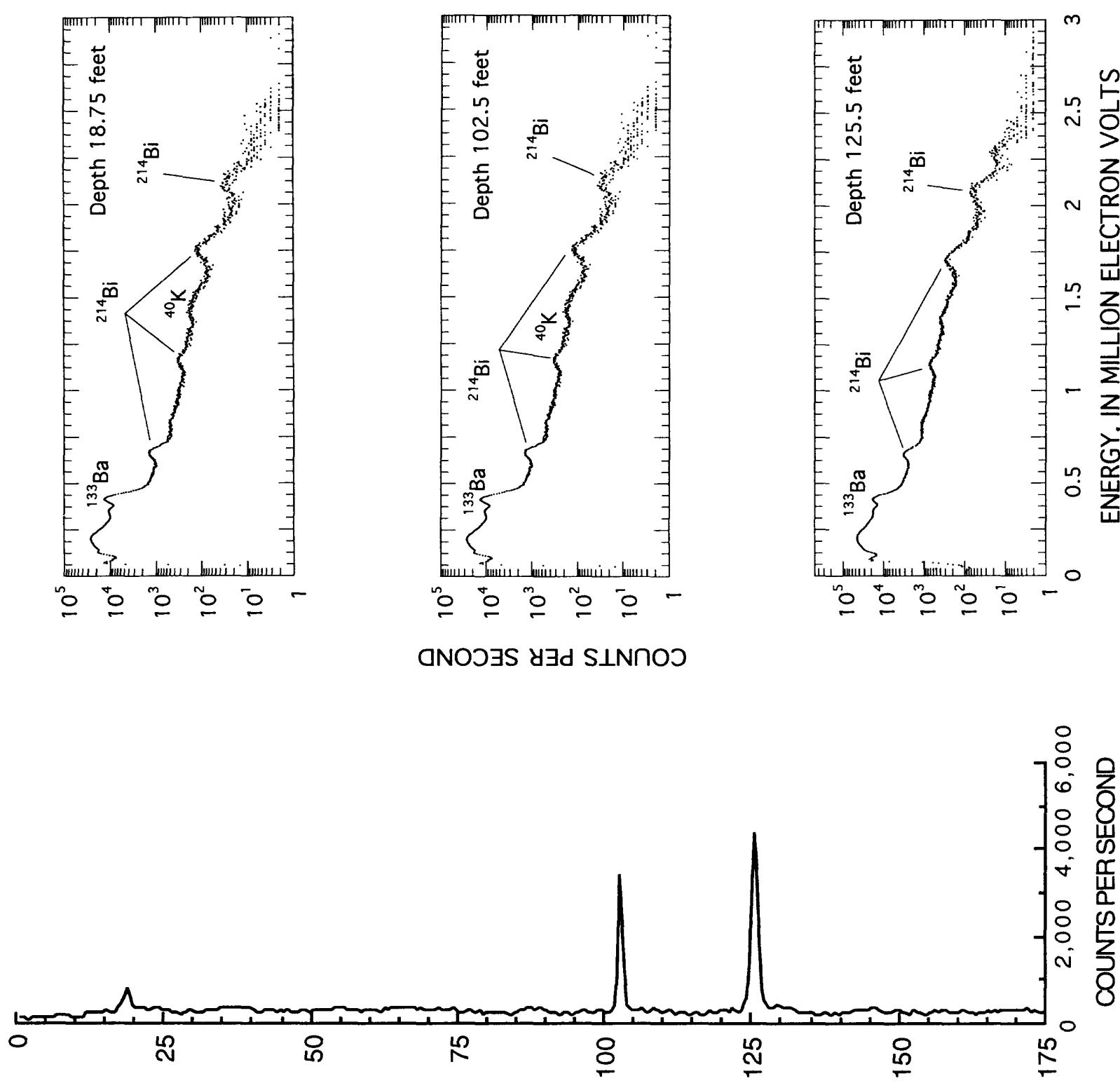
and $125 \mathrm{ft}$ (pl. 4). This mineral distribution confirms the presence of oxidizing conditions, which enhance uranium solubility, in the shallow fissured zone; reducing conditions, which enhance radium solubility, in the deeper fractured zones; and a transition zone between oxidizing and reducing conditions from 35 to $95 \mathrm{ft}$. As at well 21-358 (site 2), oxidizing, uranium-bearing water from shallow fractures may have mixed with reducing, radium-bearing water from deeper fractures during sample collection.

The concentration of ${ }^{222} \mathrm{Rn}$ in the water sample from well $19-250,22,000 \mathrm{pCi} / \mathrm{L}$, was the second highest value measured for the 10 boreholes and wells, and exceeded all proposed standards by more than an order of magnitude (U.S. Environmental Protection Agency, 1991). Gross alpha-particle activity exceeded $15 \mathrm{pCi} / \mathrm{L}$, but did not violate drinking-water standards because most of the activity is accounted for by the alpha activity emitted by uranium isotopes (U.S. Environmental Protection Agency, 1994). The concentration of uranium was high (5.6 pCi/L) but did not exceed proposed uranium drinking-water standards (U.S. Environmental Protection Agency, 1991).

In well 19-249, oxidizing water (as indicated by the presence of limonitic fracture coatings) penetrates to about $40 \mathrm{ft}$ to the fissured zone. The single-point-resistance log shows a major fluctuation to the right at about this depth, indicating the possible presence of water. Because no anomalously radioactive strata are present at this depth, however, the water was not enriched with dissolved radionuclides.

Well 19-251 penetrates zones of highly radioactive strata at 30 to $35 \mathrm{ft}$ and 190 to $195 \mathrm{ft}$, and minor radioactive zones centered at 72, 173,213,228, and $249 \mathrm{ft}$. Despite the presence of highly radioactive strata, water samples from this well were not highly radioactive.

Highly fractured rocks are present from 20 to $55 \mathrm{ft}, 175$ to $195 \mathrm{ft}, 210$ to $235 \mathrm{ft}$, and 250 to $265 \mathrm{ft}$. The deepest highly fractured sections (below $175 \mathrm{ft}$ ) are isolated from percolating water by a $120-\mathrm{ft}$ section of sparsely to slightly fractured rock. A significant proportion of the fractures (up to one-half) below a depth of $50 \mathrm{ft}$ are sealed (pl. 4). Furthermore, most of the fractures below $50 \mathrm{ft}$ are of the high-angle type, indicating the absence of connection to possible regional flow along large bedding-plane fractures. Measurements with the HPFM did not indicate any water movement below about $50 \mathrm{ft}$. Spontaneous potential was constant below $25 \mathrm{ft}$ (indicating no evidence for water-bearing zones below $25 \mathrm{ft}$ ) except near the bottom of the well below $250 \mathrm{ft}$ (pl. 4), where large fluctuations in the signal from this log make interpretation inconclusive. Most of the log data, however, indicate that water likely does not come into contact with any of the radioactive zones below a depth of $50 \mathrm{ft}$.

HPFM data indicate the presence of flowing water at $32 \mathrm{ft}$ in an extremely fractured zone consisting of a fissured zone and many open horizontal fractures between 30 and $35 \mathrm{ft}$. This section of strata coincides with a zonc of high radioactivity. Therefore, the geophysical evidence indicates that radioactive water is likely to enter the well at this point. Visual inspection of the core, however, reveals that the radioactive rocks are in a l-ft-thick zone of well-cemented, interbedded massive and laminated black mudstone that is not broken by fractures, even though open horizontal fractures are abundant immediately above and below this zone. Although geophysical data can be used to select those sites or wells where water is most likely to contain elevated concentrations of radionuclides, resolution of geophysical logs is about $1 \mathrm{ft}$, whereas the strati- 
graphic features typically are on a scale finer than this minimum resolution. Therefore, the presence or absence of anomalously radioactive water can be confirmed only by sampling.

Uranium isotopes are the dominant alpha-emitting radionuclides dissolved in the water sample from well 19-251, whereas the concentration of ${ }^{226} \mathrm{Ra}$ is low. The dominance of dissolved uranium relative to radium indicates that water intercepted by the well must be derived from shallow fracture zones where oxidizing water is present. Limonite is an abundant fracture-coating mineral to a depth of about $45 \mathrm{ft}$, indicating that oxidizing water has penetrated the formation to the depth of the major water-yielding interval in the well.

\section{Site 5}

The strata penetrated by borehole 23-1076 contain two radioactive zones: a highly radioactive zone at $42 \mathrm{ft}$ and a less radioactive zone at $57 \mathrm{ft}$. The caliper log of the adjacent well 23-1083 indicates several borehole-diameter enlargements at 50 to 55 and from 57 to $62 \mathrm{ft} \mathrm{(pl.6).}$ The BHTV indicated the presence of major fractures at depths that correspond to those of the major enlargements indicated on the caliper log. The fracture-density count indicated the presence of a moderate number of low-angle open fractures between 50 and $60 \mathrm{ft}$ that correlate with the BHTV image and the deflections on the caliper log. No low-angle fractures and only one high-angle open fracture is present between 40 and $50 \mathrm{ft}$, confirming the BHTV image of a large vertical fracture in a sparsely fractured section. Analysis of fracture-density counts, the caliper $\log$, and the BHTV $\log$ (pl. 6) indicate that the highly radioactive zone (at $42 \mathrm{ft}$ ) is not fractured, whereas the less radioactive zone (at $57 \mathrm{ft}$ ) is fractured. These results indicate that the high levels of gross alpha-particle activity and concentrations of ${ }^{226} \mathrm{Ra}$ in the water sample from borehole 23-1076 are derived primarily from the moderately radioactive fractured rocks at $57 \mathrm{ft}$.

The abundance of pyrite in the massive black (carbonaceous) mudstone penetrated by borehole 23-1076 has resulted in a reducing geochemical environment, as indicated by the near absence of limonite throughout the borehole (even at shallow depths--only trace amounts of limonite are present in the highly fractured section between $25 \mathrm{ft}$ and $35 \mathrm{ft}(\mathrm{pl} .6)$ ). The moderately fractured section from 50 to $60 \mathrm{ft}$ likely produces water; this water circulates under reducing conditions in the radioactive black mudstone at $57 \mathrm{ft}$. The water sample from borehole 23-1076 contains high concentrations of iron and manganese $(1,300 \mu \mathrm{g} / \mathrm{L}$ and $660 \mu \mathrm{g} / \mathrm{L}$, respectively) and low concentrations of DO $(0.2 \mathrm{mg} / \mathrm{L})$ (app. C), confirming the presence of a reducing geochemical environment in which uranium is insoluble and radium is likely to be in solution.

In the water sample from borehole 23-1076, only small amounts of the gross alphaparticle activity were attributed to uranium; hence, gross alpha-particle activity in water from this borehole exceeded the drinking-water standard (U.S. Environmental Protection Agency, 1994). The sum of the activities of ${ }^{226} \mathrm{Ra}$ and ${ }^{228} \mathrm{Ra}(25.92 \mathrm{pCi} / \mathrm{L})$ far exceeded $5 \mathrm{pCi} / \mathrm{L}$, the interim drinking-water-standard for radium (U.S. Environmental Protection Agency, 1994). If the proposed modification of the radium standard in which ${ }^{226} \mathrm{Ra}$ and ${ }^{228} \mathrm{Ra}$ are assigned an individual standard ranging from 5 to $20 \mathrm{pCi} / \mathrm{L}$ (U.S. Environmental Protection Agency, 1991) is adopted, the activity of ${ }^{226} \mathrm{Ra}$ in water from this borehole would exceed even the maximum ${ }^{226} \mathrm{Ra}$ standard $(20 \mathrm{pCi} / \mathrm{L})$. 


\section{Site 6}

Gamma logs from wells 03-286, 03-287, and 03-288, completed in red mudstone, siltstone, and sandstone, do not show any highly radioactive strata. Radioactivity slightly greater than background radiation values is present at $104 \mathrm{ft}$ in well 03-287 and $165 \mathrm{ft}$ in well 03-288 (pl. 5 ), but these rocks are only slightly fractured (pl. 6). The fracture-density counts indicate that most of the rocks above about $125 \mathrm{ft}$ are highly fractured, predominantly by low-angle open fractures. All the wells at the site penetrate fissured zones, all of which are located less than $75 \mathrm{ft}$ below land surface. Fracture density decreases greatly below about 100 to $150 \mathrm{ft}$, especially in the rocks penetrated by well 03-286. The number of potential water-bearing zones at depth in this well is small.

The ground-water samples from site 6 contained little radioactivity compared to samples from the other sites because neither the degree of fracturing in the most radioactive strata at this site nor the amount of uranium in the rocks where fracturing is abundant is significant compared to the other sites. For example, the anomously radioactive zone at a depth of $165 \mathrm{ft}$ in well 03-288 (the most radioactive strata at the site) is sparsely fractured and not likely to be a waterproducing zone. In the Newark Basin, however, even typical rocks not strongly enriched in uranium yield significant amounts of ${ }^{222} \mathrm{Rn}$ to circulating water. Water samples from wells $03-286,03-287$, and $03-288$ contained dissolved ${ }^{222} \mathrm{Rn}$ in concentrations ranging from 1,300 to $2,060 \mathrm{pCi} / \mathrm{L}$, which is much higher than the proposed drinking-water standard for ${ }^{222} \mathrm{Rn}$ of $300 \mathrm{pCi} / \mathrm{L}$ (U.S. Environmental Protection Agency, 1991).

More of the gross alpha-particle activity in water from the wells at site 6 is contributed by uranium than by ${ }^{226} \mathrm{Ra}$. Because the strata penetrated at site 6 consist of red mudstones with minimal pyrite or organic matter, oxygen in percolating water is consumed slowly, and the water remains oxidizing. Significant amounts of limonite were present as fracture coatings as deep as $175 \mathrm{ft}$, also indicating that water at these depths is oxidizing. Concentrations of DO as high as $6.8 \mathrm{mg} / \mathrm{L}$ were measured in water from well $03-288$. Uranium is more soluble than radium in such an oxidizing environment.

\section{Basinwide}

Lithologic factors, fracture characteristics, and water-quality characteristics with regional significance were evaluated with respect to the distribution of radioactivity in ground water in the Newark Basin. The presence of radioactivity in ground water at any single location depends on the presence of radioactive strata, but the distribution of radioactivity in ground water on a regional scale also depends on the continuity of radioactive strata; the frequency of occurrence of these strata in the geologic column; the orientation of fractures, especially within the radioactive strata; and the amounts of fracture interconnectedness and water circulation (interpretation based on well yield) within the radioactivity-bearing geologic formation. 


\section{Lithology}

The radioactivity of ground water in the Newark Basin, in general, depends on the concentration of radioactive minerals in the rocks. Highly radioactive water samples (gross alphaparticle activity greater than $15 \mathrm{pCi} / \mathrm{L}$ and ${ }^{222} \mathrm{Rn}$ concentration greater than $3,000 \mathrm{pCi} / \mathrm{L}$ ) were obtained from four of the six boreholes and wells that penetrated highly radioactive strata. Water samples from all of the four boreholes and wells that did not intersect highly radioactive strata were not highly radioactive, although some radioactivity was detected because uranium and thorium were present in minor amounts even in rocks considered to contain background concentrations of radioactivity (app. B-2). Therefore, the presence of anomalously high levels of radioactivity in rocks at any given location indicates high potential for radioactive ground water.

\section{Continuity of Radioactive Lithologies within Formations}

Because the regional distribution of radioactivity in ground water depends, in part, on the continuity of radioactive lithologies within formations, the stratigraphic continuity of the radioactive zones at two of the study sites--one in the Stockton Formation and one in the Passaic Formation--was determined and the relation between continuity of radioactive strata and depositional facies was evaluated.

Both qualitative analysis of gamma-log patterns and calculated dip angles indicate that the radioactive zones at site 3 , where boreholes and wells are completed in the lower part of the Passaic Formation (fig. 11), are laterally continuous. (The location of section line B-B' in figure 11 is shown in figure 2.) Gamma logs obtained from borehole 21-290 and well 21-289, which are $850 \mathrm{ft}$ apart in the direction of dip, show anomalous peaks and background patterns that correlate closely (vertical difference less than $1 \mathrm{ft}$ ). The calculated dip of the radioactive zones that are assumed to be correlated is $5.7 \pm 4.5$ degrees. Field measurements of strike and dip at this location are sparse, but the dip averages about $10 \pm 5$ degrees. The similarity between bedding orientations measured in the field and the calculated lateral trend of the radioactive zones indicates that the calculated dip angle is reasonable and that the zones constitute a laterally continuous stratigraphic horizon.

Results at site 2 (fig. 12), where boreholes are completed in the Stockton Formation, were more ambiguous than those at site 3 . (The location of section line $A-A^{\prime}$ in figure 12 is shown in figure 2.) Gamma logs obtained from well 21-358 and borehole 21-359, which are approximately $1,100 \mathrm{ft}$ apart in the direction of dip, showed less distinct qualitative correlations in gamma patterns than the logs obtained from the wells at site 3 . Zones of anomalously high radioactivity in the gamma logs at site 2 appear as clusters of anomalous peaks grouped in sections of strata several tens of feet thick, in contrast to the distinct, single peaks in the lower part of the Passaic Formation at site 3 . Therefore, visual correlation between radioactive zones was more subjective than at site 3 . If the two shallower zones of anomalously high radioactivity in each borehole are assumed to be correlated, the calculated dip of the strata is $5.3 \pm 1.4$ degrees. Many field measurements of local dip angles were made; they ranged from 8 to 23 degrees with an error of \pm 5 degrees (Hugh Houghton, New Jersey Department of Environmental Protection, oral commun., 1987). The similarity between bedding orientations measured in the field and the calculated lateral trend of the radioactive zones indicates that the calculated dip angle is reason- 


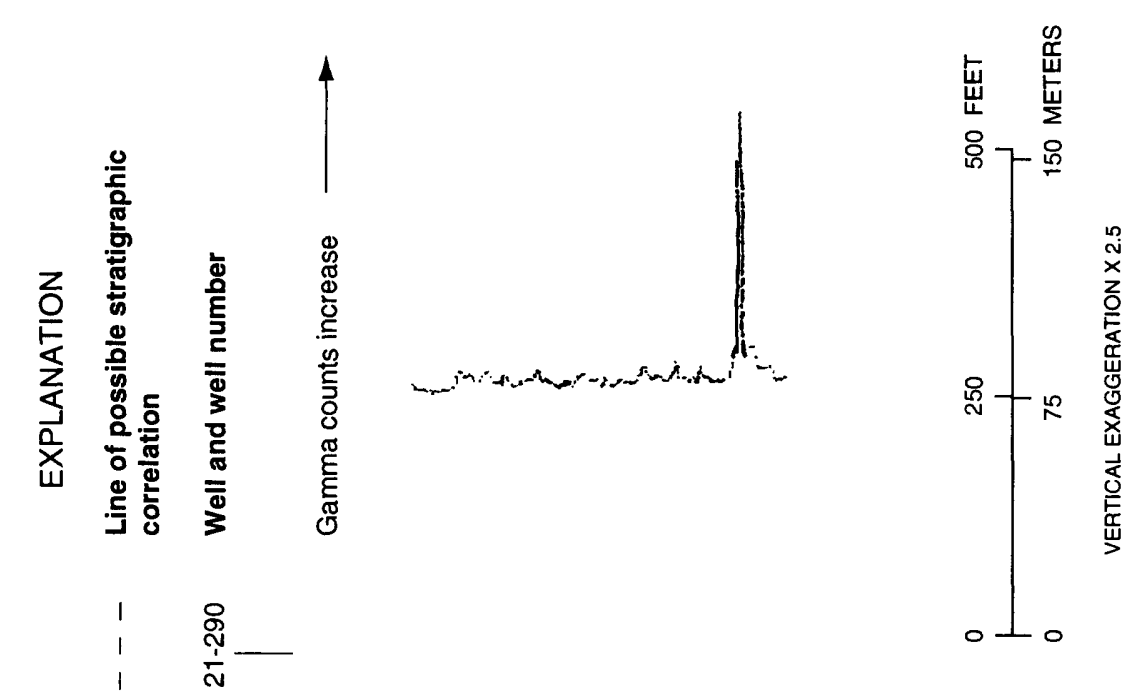

$\frac{\ddots}{6}$

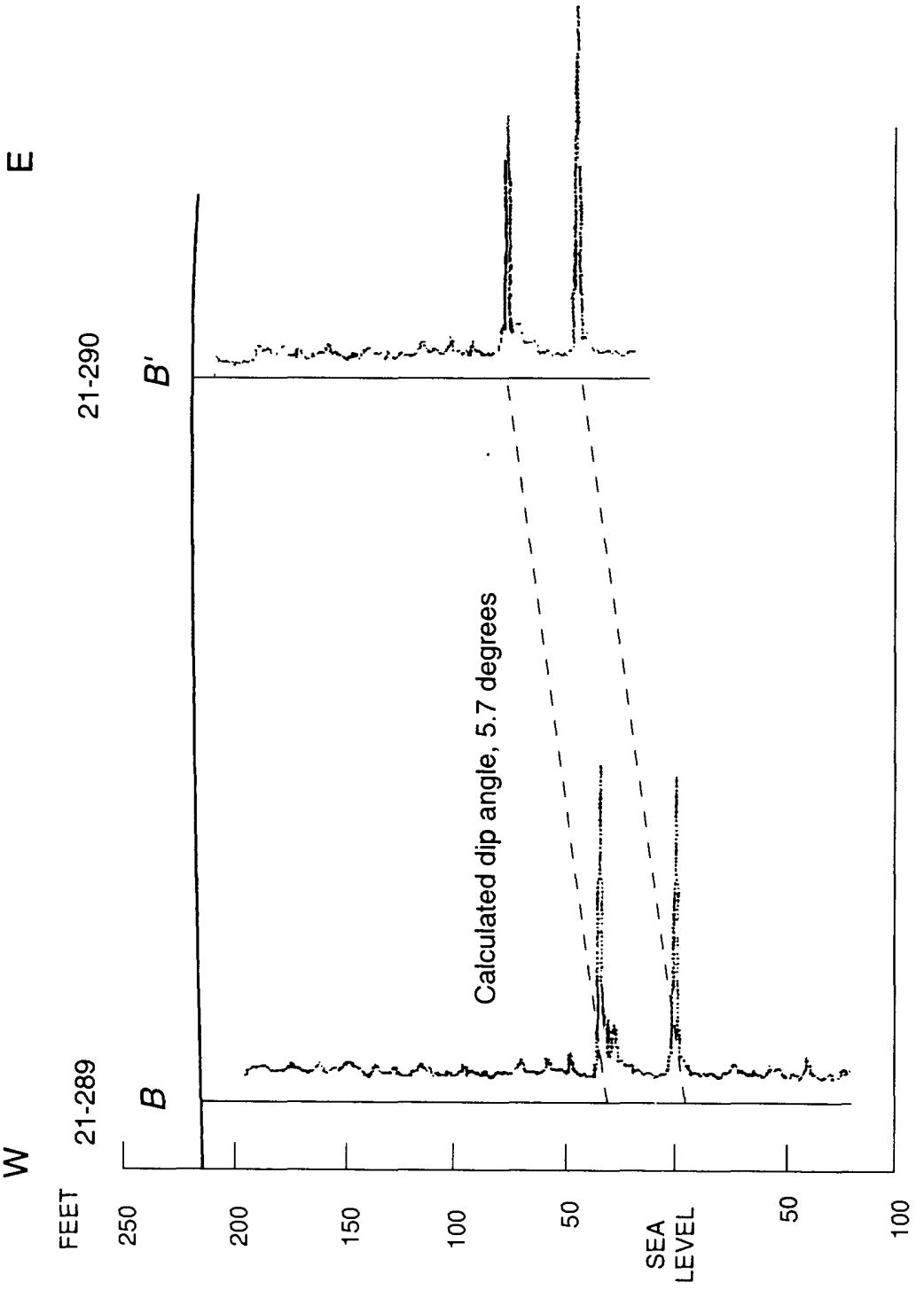

:

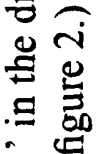

क

흘

遇

잉응

क

능

$\$$.

ธี่

造

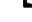


able and that the zones constitute a laterally continuous stratigraphic horizon. Each gamma log (from well 21-358 and borehole 21-359), however, shows a zone of anomalously high radioactivity that cannot be correlated to a radioactive zone in the other borehole or well either by the shape of the gamma pattern or by projection (fig. 12). Therefore, it can be concluded that several zones of anomalously high radioactivity in these boreholes in the Stockton Formation lack stratigraphic continuity. Alternatively, individual fining-upward sequences may undergo considerable thinning and thickening over short lateral distances; consequently, even if the radioactive strata are laterally continuous, they may not be oriented as a series of parallel planes.

The Stockton Formation has been interpreted as representing a marginal lacustrine depositional environment influenced by fluvial deltaic depositional environments (Turner-Peterson, 1980; Turner-Peterson, 1988). The lithology varies laterally and the strata are lenticular. The lithology at site 2 is dominated by fining-upward sequences of coarse conglomerates (gravel deposits) interbedded with gray sandstones and red mudstones and siltstones that may represent fluvial or deltaic deposits of limited lateral continuity. Thus, many radioactive zones (associated with gravel deposits) in the Stockton Formation probably are stratigraphically continuous only over short distances.

The basal part of the Passaic Formation is interpreted as interbedded lacustrine and playa sediments deposited in the Newark Basin during the waxing and waning of a large lake (Van Houten, 1980). These deposits are stratigraphically continuous throughout most of the Newark Basin (Turner-Peterson and others, 1985); in fact, the black lakebed deposits are the most stratigraphically continuous deposits in the Basin (Turner-Peterson, 1980). The strata at site 3 consist of typical interbedded lacustrine and playa sediments; because the zones of anomalously high radioactivity are in the black lakebed deposits, they would likely be laterally continuous over longer distances than the radioactive zones at site 2 . The gamma logs obtained at site 3 verify this hypothesis and indicate that zones of anomalously high radioactivity are continuous along planar horizons that approximate the angles of strike and dip of the bedding. Therefore, ground water in the lower part of the Passaic Formation has the potential to be highly radioactive in a large, continuous area aligned along the strike of one of these beds. Ground water in the Stockton Formation, in contrast, is not likely to contain high levels of radioactivity in a large, continuous area because the radioactive zones are present as discontinuous pockets.

\section{Frequency of Occurrence of Radioactive Lithologies within Formotions}

The greater the frequency of occurrence of radioactive zones within a vertical section of strata, the greater the probability that a water-bearing fracture zone will intersect a radioactive zone. Uranium appears to be enriched to varying degrees in certain lithologies at all the sites investigated, in both the Stockton and Passaic Formations. The number of radioactive zones penetrated by each of the boreholes and wells was compared to fracture density to determine qualitatively the probability of encountering radioactive water at any well site within these two geologic formations. 

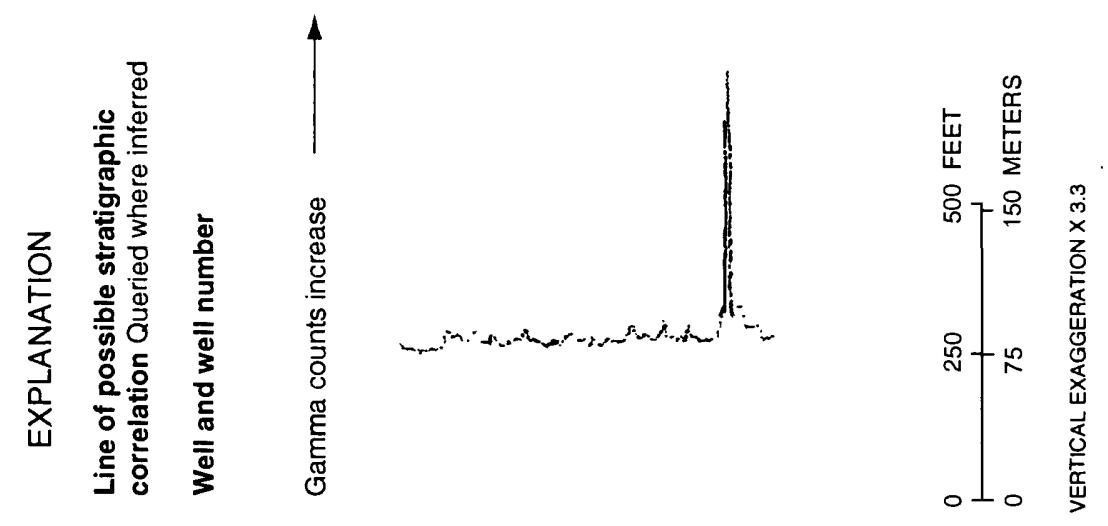

:은

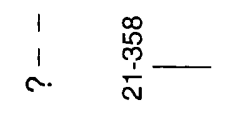

.气

元

异苛

«.

文

.ํㅠㄹ

站

은

寻.

岕

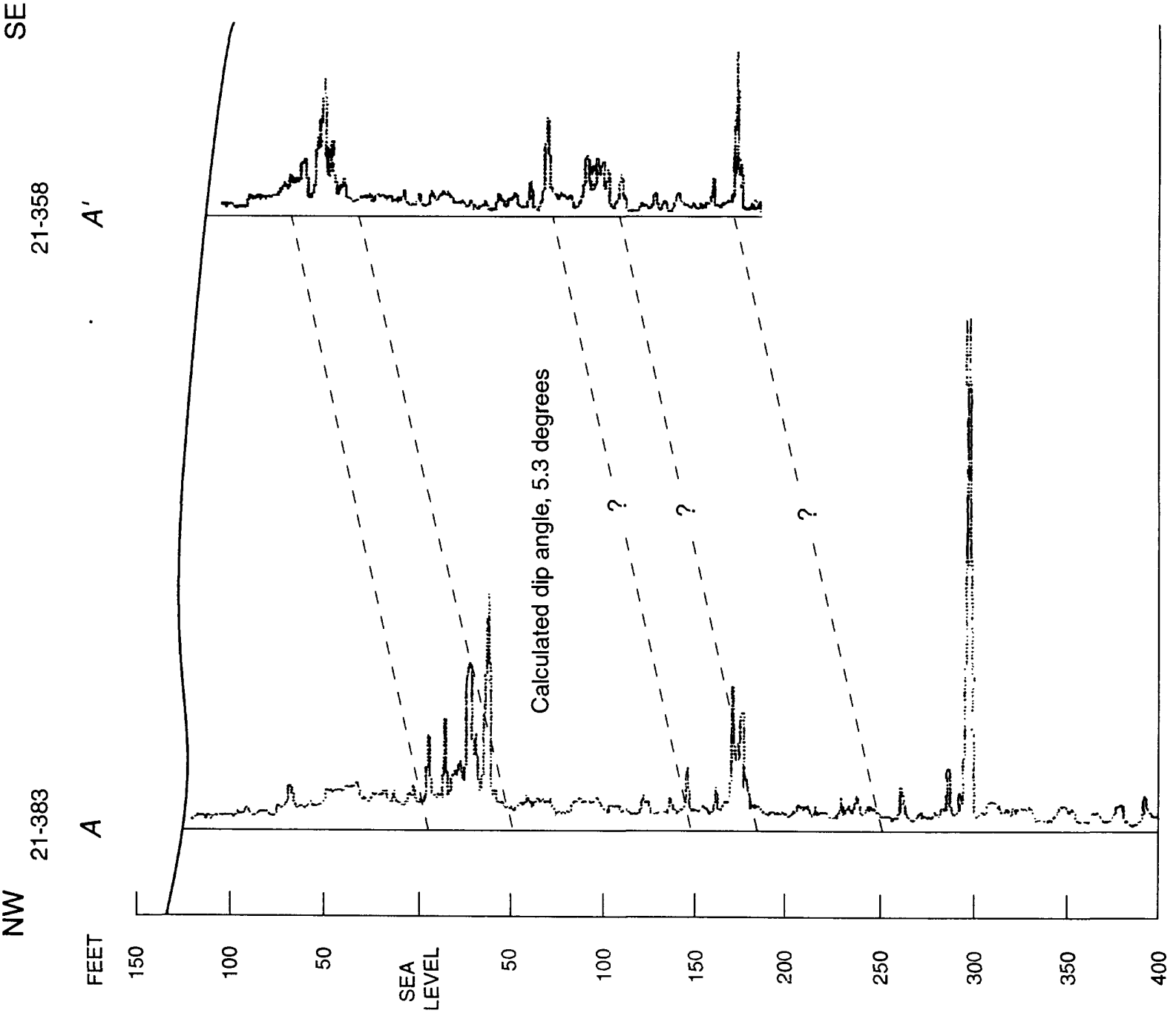

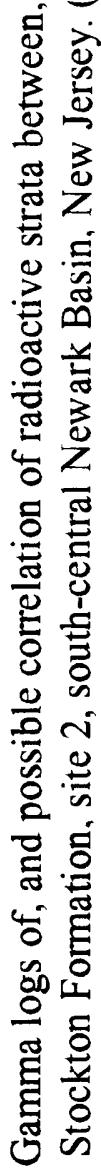

놀 
Because the deposition of the sediments comprising the Stockton Formation was cyclic, conglomerates adjoin fine-grained siltstone or mudstone in many places in a typical vertical section. The cyclic deposition of these sediments resulted in great variations in permeability horizontally and vertically. During diagenesis, fluids moving through the sediment are channeled through the most permeable zones. Uranium enrichment can result when large quantities of formation water deposit radioactive minerals in the presence of organic matter in these zones. The presence of highly radioactive zones within basal conglomerates is consistent with the lacustrian-humate model for uranium enrichment proposed by Turner-Peterson (1980). The most permeable sands and gravels of the Stockton Formation are radioactive as a result of precipitation from uranium- and humate-rich pore fluids that migrated through the permeable zones after they were expelled from the black mudstones during compaction.

Many radioactive zones are present in the Stockton Formation at site 2 (fig. 12). Most of the stratigraphic intervals in which levels of radioactivity are high are found in the basal conglomerate in a fining-upward sequence that overlies mudstones. Some of the conglomerates also contain organic-rich gravel and sand zones that also are highly radioactive (pl. 1). The presence of these zones together with the dense fracturing, especially within $125 \mathrm{ft}$ of land surface, result in a high potential for the presence of radioactive water in the Stockton Formation.

The sediments of the Lockatong Formation and the lower part of the Passaic Formation (site 4) consist of cyclic lenticular lacustrine sequences (Van Houten, 1962). The intercalated black and white mudstones and siltstones that favor uranium enrichment are common and are associated with sharp changes in grain size in the nearshore lacustrine part of the sequences. Turner-Peterson (1977) reported that similar radioactive black mudstones in the Lockatong Formation could be organic-rich lakebed muds that sorbed uranium from the overlying lake water. The presence of many uranium-enriched strata increases the probability that water-bearing fractures will intercept radioactive zones.

Gamma logs obtained from wells at site 4 and the nearby withdrawal wells were projected onto a single line of section, C-D-E-F-G (fig. 2); this section shows that many radioactive zones are present at this site and that they commonly are separated vertically by less than $100 \mathrm{ft}$ (fig. 13). Although the shape and magnitude of many gamma peaks for strata from wells 19-249, 19-250, and 19-085, and those of many gamma peaks for strata from wells 10-251 and 19-285 are similar, the resulting calculated dip angles do not agree with field-measured dip angles. Therefore, the strata cannot be demonstrated to be correlated.

In the lower part of the Passaic Formation (sites 3 and 5), the lacustrine sequences are interspersed with playa facies, and are less common as the rocks decrease in age (playa facies become dominant) in the lower part of the Passaic Formation. Strata most likely to be enriched with uranium are separated by greater thicknesses of intervening strata as the age of the rock decreases; thereby, the probability decreases that water-bcaring fractures will intersect radioactive zones in younger rock relative to older rock. Strata at sites 3 and 5 contain few radioactive zones. At site 3, the radioactive zone intersected by borehole $21-290$ is overlain by $140 \mathrm{ft}$ of nonradioactive rocks. At site 5, in strata penetrated by well 23-1083 adjacent to borehole 23-1076, two of three radioactive strata are separated by $350 \mathrm{ft}$ of nonradioactive rocks (Taylor, 1989). 

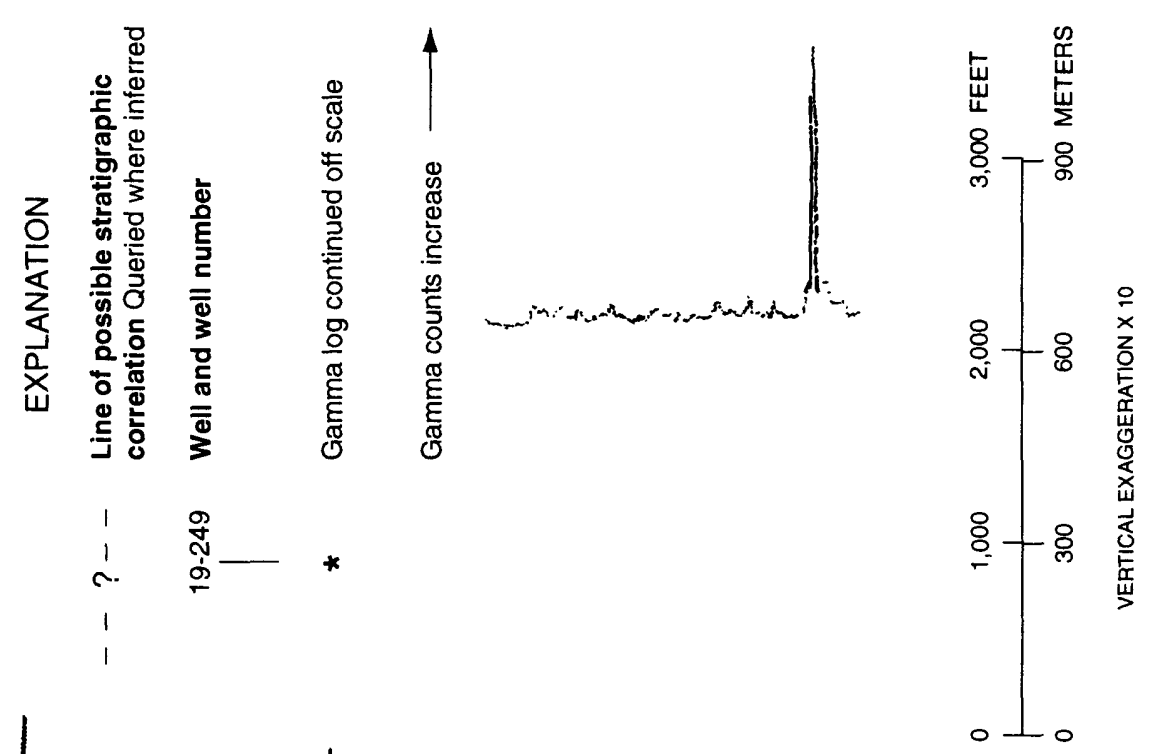

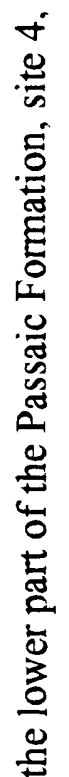

ш

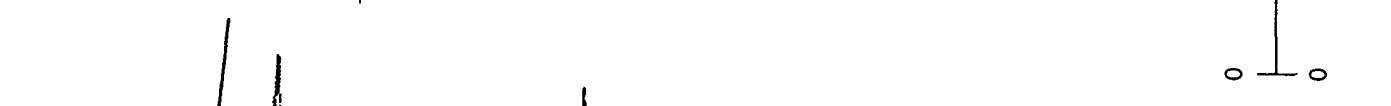

홍

نे

을 율

券

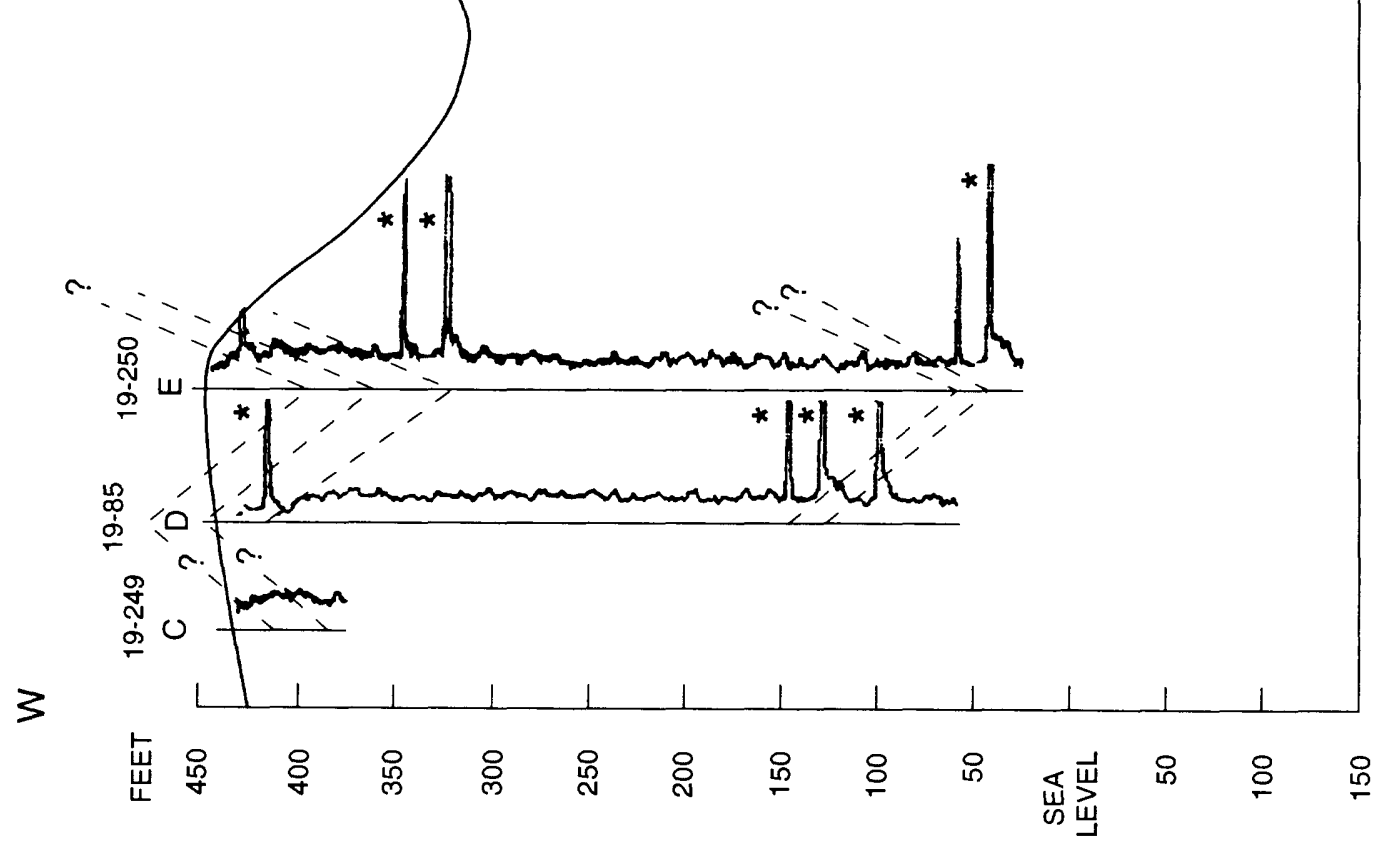

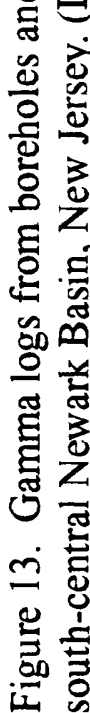


Cyclic fining-upward red siltstone/mudstone sequences dominate the youngest rocks of the lower part and all of the middle and upper parts of the Passaic Formation and represent a sabkha depositional environment. These rocks are uranium-poor and contain only few slightly radioactive zones because organic material, the primary reducer and precipitator of uranium in the depositional environments of the Newark Basin, is absent. Many cyclic fining-upward clastic sequences are present in the Passaic Formation at site 6 . The red siltstones are not highly radioactive. Only a few zones in which radioactivity is slightly higher than background levels are present. Even in the red mudstone of the Passaic Formation at site 6, which contains little uranium, the highest gamma counts were nevertheless obtained at the contact between a coarsegrained basal sandstone and the massive mudstone that caps the fining-upward sequence immediately beneath it. This result indicates that the location of low-level uranium enrichment in the red mudstone and siltstone of the lower part of the Passaic Formation is stratigraphically similar to that of the highly enriched zones in the arkose of the Stockton Formation and the black mudstone of the lower part of the Passaic Formation. Because the radioactive zones are sparse, however, fractures in the red mudstones of the Passaic Formation (especially those at site 6) are not likely to intersect radioactive zones.

\section{Orientation of Fractures}

The amount of radioactivity in the ground water derived from the highly radioactive layers of rock in the Newark Basin depends on the length of the fracture in the radioactive zone and the ratio of the surface area of the fracture that is in the radioactive rock to the amount of water that flows through the fracture. Water in horizontal and low-angle fractures associated with bedding planes flows farther through radioactive zones than water in vertical or high-angle fractures, especially in the Passaic Formation (Michalski, 1990). Therefore, the water flowing in these fractures is in contact with the radioactive strata at the fracture surface over a greater distance than water flowing along a vertical fracture that cuts radioactive strata. Typically, the concentrations of dissolved radionuclides in the water produced from radioactive strata that are intersected by wellconnected horizontal fractures that have a large surface area in radioactive rock are greater than those produced from less well-connected vertical fractures that have a smaller surface area in radioactive rock.

Low well yields, especially at site 4 , indicate that well-connected water-bearing fractures are less common in the basal part of the Passaic Formation than in the Stockton Formation or the middle to upper part of the basal part of the Passaic Formation, where red mudstone is common. Wells 23-1083 (site 5) and 21-358 (site 2) penetrate strata in which horizontal fractures dominate; the yields of these wells are greater than that of well 19-251 (site 4), which penetrates black mudstone strata in the basal part of the Passaic Formation, in which vertical fractures dominate (tables D1, D4, and D6). Water produced from borehole 23-1076 (adjacent to well 23-1083) and well 21-358 contains greater concentrations of radioactivity than water produced from well 19-251. Therefore, water from wells completed in black mudstone at the base of the Passaic Formation (for example, at site 4) is no more likely to be radioactive than water from wells that are stratigraphically higher in the formation despite the presence of many more zones of high radioactivity because the number of well-connected horizontal fractures is also smaller. Wellyield data for, and concentrations of radioactivity in water from, sites 2,4 , and 5 support the 
assumed importance of fracture orientation (specifically, the importance of well-connected horizontal fractures) in determining the presence of high concentrations of radioactivity in ground water at any site in the Newark Basin.

\section{Ground-Water Quality}

The chemical composition of ground water was studied to determine the relation of water quality to the mineralogy of the rocks penetrated by the borehole, the differences in water quality of samples from different rock types, the relation of radionuclide concentrations in water samples to radionuclide content of the rock matrix, and the solubility of radionuclides in water of differing chemical composition.

Water quality is related to the mineralogy and chemical composition of the rocks penetrated by the borehole or well. The dominance of calcium and bicarbonate ions in the groundwater samples is consistent with the large quantity of secondary calcite in the rock matrix (pl. 3). Calcite is known to dissolve rapidly in shallow ground water. Etched and pitted calcite was prominent in core samples collected during this study, especially those from site 4, indicating the dissolution of calcite from the rock matrix. Dissolution of calcite from rocks of the Newark Supergroup has been documented by other investigators. Rima (1955) described etched and pitted calcite in rock samples collected from a production well in the Newark Basin. Rogers (1987) concluded from geochemical-model simulations that the dissolution of calcite is a major geochemical control on the quality of water in the rock aquifers of the geologically similar Hartford Basin.

The effect of calcite in the rock matrix on water quality is evident even in the two wells (21-358 and 19-249) from which chloride-dominated water was pumped. The stratigraphic columns (pls. 1 and 3 ) show that calcite is dispersed in the matrix of the rock penetrated by these wells (especially for well 19-249), and the water-quality data from well 19-249 show that the concentration of calcium and bicarbonate was about as great as those in water in which the concentration of sodium and chloride was lower (fig. 8). The water sample from well 21-358, however, contained bicarbonate in a substantially lower concentration than those measured in the water samples from other boreholes and wells in the study, probably because the matrix in the coarse-grained sandstone in the Stockton Formation at site 2 contains only small amounts of calcite (pl. 1), especially at a depth of about 60 to $80 \mathrm{ft}$, where a large number of water-bearing fractures are located (pl. 2). The $\mathrm{pH}$ of the water sample from this well was also lower than those of water samples from the other boreholes and wells, as would be expected when little soluble calcite is present in the rock. Because coarse-grained sandstone with only a trace amount of carbonate cement is common in the Stockton Formation, this formation contains water in which $\mathrm{pH}$ and alkalinity are lower than in water from the Passaic Formation.

Chemical analysis of whole-rock samples indicates that calcium, strontium, and barium are common in the rocks of the Newark Basin; especially in samples from the black and red mudstones. Large amounts of calcium and inorganic carbon in the water are derived from inorganic carbon in the rock (app. B-1) present as soluble secondary calcite cement. Strontium and barium are present as trace elements in the carbonate and feldspar minerals that are common in 
the rocks. Strontium typically is found in high concentrations in calcite and anorthosite, whereas barium is found in high concentrations in potassium feldspar and potassium-bearing clay minerals. Concentrations of strontium were higher in whole-rock samples of the mudstones from the lower part of the Passaic Formation than in whole-rock samples of arkosic sandstones from the Stockton Formation (app. B-1) because of the abundance of calcite cement in the former. Strontium is readily accessible to ground water because calcite is soluble. The large variation in concentrations of strontium among the formations investigated results in large differences in concentrations of strontium in the water contained in these formations. Concentrations of barium in the water samples were relatively uniform because the concentrations of barium in the three lithologies are relatively uniform (as compared to strontium, for example).

The concentration of lithium was higher in whole-rock samples collected from the mudstones in the lower part of the Passaic Formation than in those collected from the Stockton Formation (app. B-1). Dean (1988, p. 84) reported that lithium was present in high concentrations in trioctohedral illite-smectite minerals in mudstone of the Passaic Formation. The high concentration of lithium in water samples from the lower part of the Passaic Formation (app. C) illustrates that the dissolved concentration of this trace element is controlled at least partly by its abundance in the rocks in the Newark Basin. Other trace elements (arsenic, cadmium, lead, molybdenum, nickel, zinc, and aluminum) detected in the water samples were present in the whole-rock samples in greater concentrations than those of trace elements that were not detected in the water samples (app. B-1).

All four boreholes and wells (19-250, 21-358, 23-890, and 23-1076) that yielded water samples containing gross alpha-particle activities greater than $15 \mathrm{pCi} / \mathrm{L}$ penetrate anomalously radioactive strata. Concentrations of dissolved ${ }^{222} \mathrm{Rn}$ gas in water samples from these boreholes and wells were greater than $3,000 \mathrm{pCi} / \mathrm{L}$, with the exception of borehole 23-1076, from which no sample was collected for analysis for ${ }^{222} \mathrm{Rn}$ gas. Four wells $(03-286,03-287,03-288$, and 19-249) did not penetrate any anomalously radioactive strata; concentrations of dissolved ${ }^{222} \mathrm{Rn}$ gas and gross alpha-particle activities in water samples from these wells were less than 3,000 and $15 \mathrm{pCi} / \mathrm{L}$, respectively. Therefore, it appears that ground water in the Newark Basin that contains gross alpha-particle activities greater than $15 \mathrm{pCi} / \mathrm{L}$ and concentrations of ${ }^{222} \mathrm{Rn}$ greater than $3,000 \mathrm{pCi} / \mathrm{L}$ must be in contact with radioactive rocks.

Wells $19-251$ and 21-175 penetrate anomalously radioactive strata; however, water samples collected from them do not contain high gross alpha-particle activities or ${ }^{222} \mathrm{Rn}$ concentrations. Therefore, although anomalously radioactive strata must be present to produce high concentrations of radioactive constituents in ground water in the Newark Basin, other hydrogeologic and geochemical factors such as fracture density and water-rock interaction also are critical.

Gross alpha-particle activity was higher than concentrations of either uranium or ${ }^{226} \mathrm{Ra}$ in water samples collected from boreholes and wells that penetrated radioactive strata. In water samples from four of the boreholes and wells, nearly all of the gross alpha-particle activity is accounted for by the sum of the activities of ${ }^{226} \mathrm{Ra},{ }^{238} \mathrm{U},{ }^{234} \mathrm{U}$, and ${ }^{235} \mathrm{U}$ (fig. 14). Only one of these samples contained gross alpha-particle activity greater than $15 \mathrm{pCi} / \mathrm{L}$, however. In contrast, the sum of the activities of ${ }^{226} \mathrm{Ra},{ }^{238} \mathrm{U},{ }^{234} \mathrm{U}$, and ${ }^{235} \mathrm{U}$ in samples of water from four other bore- 


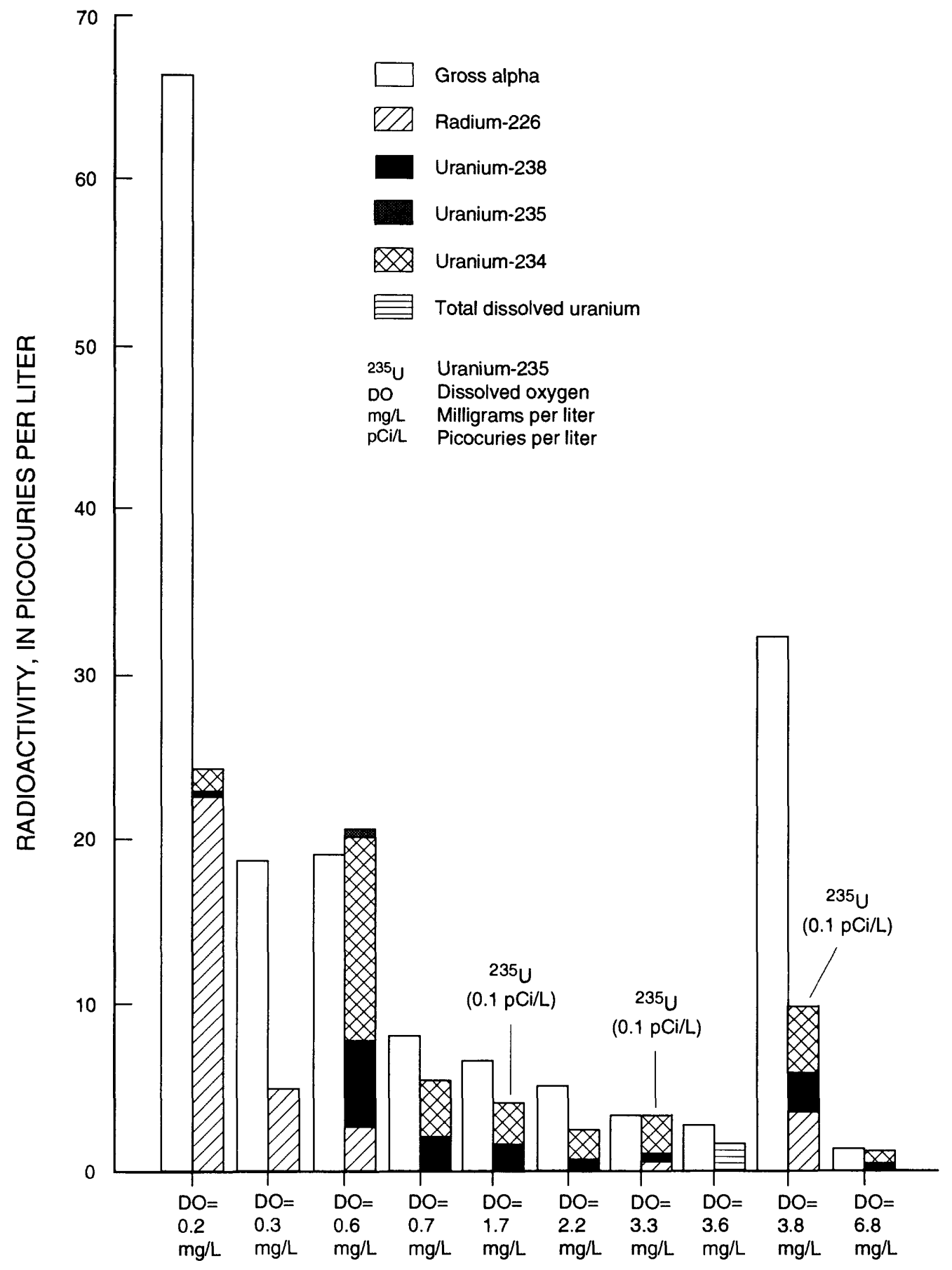

RANKED DISSOLVED-OXYGEN CONCENTRATION

Figure 14. Relation between gross alpha-particle activity and sum of radium-226, uranium-238, uranium-234, and uranium-235 activities as a function of dissolved-oxygen concentration in water samples from 10 wells and boreholes, south-central and northeastern Newark Basin, New Jersey, 1985-91. 
holes and wells was less than one-half the gross alpha-particle activity (fig. 14), and gross alphaparticle activities exceeded $15 \mathrm{pCi} / \mathrm{L}$ in three of these four samples. Therefore, it appears that the portion of the gross alpha-particle activity that is attributable to the sum of ${ }^{226} \mathrm{Ra},{ }^{238} \mathrm{U},{ }^{234} \mathrm{U}$, and ${ }^{235} \mathrm{U}$ decreases as the gross alpha-particle activity in the sample increases.

In all but 3 water samples from the 10 boreholes and wells (the samples from wells $21-358,23-801$, and 23-1076), the gross alpha-particle activity is attributable primarily to the activity of either ${ }^{226} \mathrm{Ra}$ or uranium isotopes $\left({ }^{238} \mathrm{U}\right.$ and $\left.{ }^{234} \mathrm{U}\right)$. The proportion of gross alphaparticle activity attributed to ${ }^{226} \mathrm{Ra}$ and to $\mathrm{U}$ isotopes varies from well to well. In eight water samples, uranium isotopes accounted for more of the gross alpha-particle activity than $\mathrm{did}^{226} \mathrm{Ra}$, and in five of these samples, uranium isotopes accounted for most of the gross alpha-particle activity (fig. 14). In two samples (those from well 23-801 and borehole 23-1076), ${ }^{226} \mathrm{Ra}$ contributed more of the gross alpha-particle activity than the uranium isotopes, even though the well and borehole penetrate uraniferous strata. About one third of the gross alpha-particle activity in water from these two wells was attributable to ${ }^{226} \mathrm{Ra}$ (app. C; fig. 14).

In order to understand the effect of ground-water geochemistry on the distribution of radionuclides in solution, the ratio between the sum of uranium (all isotopes) and ${ }^{226} \mathrm{Ra}$ activities and gross alpha-particle activity was ranked according to the concentration of DO for each of the 10 ground-water samples. This ranking indicated a strong positive relation between the ratio of uranium to gross alpha-particle activity and $\mathrm{DO}$ concentration and a strong negative relation between the ratio of ${ }^{226} \mathrm{Ra}$ to gross alpha-particle activity and DO concentration (fig. 14). All four samples that contained DO in concentrations less than $1.0 \mathrm{mg} / \mathrm{L}$ also contained detectable concentrations of dissolved ${ }^{226} \mathrm{Ra}$ (fig. 14); the ratio of ${ }^{226} \mathrm{Ra}$ to gross alpha-particle activity in these samples increased as the DO concentration decreased.

The concentration of uranium was negligible compared to gross alpha-particle or ${ }^{226} \mathrm{Ra}$ activity in the water sample from borehole 23-1076; no uranium was detected in the water sample from well 23-801. The solubility of uranium in the geochemical environment of the water intercepted by the well and borehole is limited. Water from this well and borehole contained significantly more dissolved iron than water from the other eight boreholes and wells (app. C). A study by Cochran and others (1986) has shown that uranium is reduced from the soluble +6 valence to the insoluble +4 valence as iron is reduced from the insoluble +3 valence to the soluble +2 valence. The absence of uranium from the iron-rich ground-water samples collected from the Newark Basin is due to the reduction of uranium to the insoluble +4 valence. In contrast, uranium remains oxidized and soluble in oxygenated, iron-poor ground water and, hence, was the dominant source of gross alpha-particle activity in samples containing high concentrations of DO and low concentrations of iron.

Concentrations of uranium in water samples from site 4, especially those from wells 19-249 and 19-251, were higher than those of radium because the water is oxidizing. Water pumped from these wells is derived from shallow strata ( $50 \mathrm{ft}$ or less below land surface) in which the geochemical environment tends to be oxidizing and favors dissolution of uranium over dissolution of radium. In contrast, high concentrations of both uranium and radium were measured in the sample from well 19-250. This sample contained a low concentration of DO, no detectable nitrate, and high concentrations of dissolved iron and manganese--evidence that the geochemical environment of the water tapped by the well is reducing and favors dissolution of radium over that 
of uranium. The composition of fracture coatings in rocks penetrated by all three wells at site 4 confirms the following vertical distribution of geochemical environments: iron hydroxides are prominent in shallow (at depths of about 20-45 ft) water-bearing fractures (oxidizing environment), but are absent from water-bearing fractures in deeper (generally below about 70-100 ft) rocks (reducing environment). The geochemical environment generally becomes more reducing with depth because oxygen is consumed along the flowpath during water-rock interactions such as the oxidation of pyrite and chlorite (pl. 3). Szabo and Zapecza (1987) hypothesize that the iron hydroxides coating the fractures in oxidizing environments limit the mobility of radium by the strong adsorption capacity for radium.

Iron hydroxides as fracture-coating minerals generally are found to greater depths in the arkose in the Stockton Formation and the red mudstone in the lower part of the Passaic Formation than in the black mudstone in the lower part of the Passaic Formation, indicating that water at depth in the black mudstone is less likely to be oxygenated than water at depth in the other two rock types. Therefore, uranium is less likely and ${ }^{226} \mathrm{Ra}$ is more likely to be present in solution in water in the black mudstone than in the other rock types. The effect of DO on the solubility of uranium and ${ }^{226} \mathrm{Ra}$ observed during this study is consistent with the regional redox-sensitive solubility phenomenon reported by Szabo and Zapecza (1987) for the Newark Basin; they report that high concentrations of dissolved ${ }^{226} \mathrm{Ra}$ were found most commonly in water from wells completed in black mudstone in the lower part of the Passaic Formation and the Lockatong Formation, whereas high concentrations of dissolved uranium were found most commonly in water from wells completed in the arkose in the Stockton Formation.

\section{SUMMARY AND CONCLUSIONS}

Depositional and diagenetic processes in the Stockton Formation and the lower part of the Passaic Formation in the Newark Basin of New Jersey have resulted in the presence of many zones of radioactive strata that are cyclically distributed and are the source of radioactivity in the ground water. The high frequency of occurrence of these radioactive strata within these two formations assures that circulating water will interact with radioactive rocks.

The spatial distribution of radioactivity in ground water in the Newark Basin depends on several factors: the concentration of radionuclides in the rocks; the continuity of radioactive strata on a regional scale; the frequency of occurrence of radioactive strata; the depth, orientation, and continuity of fractures; and the geochemical environment, which can enhance or limit the solubility of radionuclides. These factors were investigated at 11 boreholes and observation wells and 8 completed production wells at 6 sites in the Newark Basin by the collection of geologic and hydrologic data (macroscopic examination of core samples), borehole geophysical analyses (gamma logs, gamma spectral logs, caliper logs, borehole televiewer logs, spontaneous-potential logs, single-point-resistance logs and heat-pulse-flowmeter logs), and geochemical data (chemical and gamma spectral analyses of whole-rock samples from 3 cores, and water-quality samples collected from 10 of the 11 boreholes and wells). 
Zones of anomalously high radioactivity were recorded on gamma logs obtained in conglomerate and arkosic sandstone of the Stockton Formation and in black or gray mudstone interbedded with calcite-cemented silt layers of the lower part of the Passaic Formation in the south-central part of the Newark Basin. The presence of elevated concentrations of uranium in most strata that emitted anomalous amounts of gamma radiation was verified by means of borehole gamma-ray spectrometry.

The maximum concentration of uranium in the black mudstone of the lower part of the Passaic Formation $(6,200 \mathrm{ppm})$ was nearly a thousand times the average concentration in typical black and red mudstone in the same borehole and was substantially greater than the concentration of thorium in any of the strata. The ratio of the concentration of uranium to that of thorium in all the samples of the black and gray mudstone exceed this ratio in red mudstone, indicating enrichment of uranium in black mudstone.

Only one slightly radioactive whole-rock arkose sample was analyzed; the concentration of uranium was $15 \mathrm{ppm}$. Gamma counts recorded in other boreholes that penetrate radioactive arkose of the Stockton Formation were at least an order of magnitude greater than those recorded at the depth from which the whole-rock arkose sample was collected, indicating that uranium concentrations in some parts of the formation could be an order of magnitude greater than 15 $\mathrm{ppm}$. Ratios of the concentration of thorium to that of uranium in arkose varied even within the same borehole, but were significantly lower than the value of about 4.0 that is typical for sandstones. This result indicates the presence of slight uranium enrichment even in samples of arkose that contain nearly background levels of radioactivity.

The Stockton and Passaic Formations consist of cyclic repetitions of fining-upward sequences. The cyclic deposition of sediments in the Newark Basin provided ideal conditions for extreme variations in permeability. Water flowed preferentially through the most permeable zones during diagenesis, resulting in zones of uranium enrichment. Cores from both formations indicate that uranium is consistently enriched in permeable sections of strata that are adjacent to less permeable zones. In the arkose of the Stockton Formation at sites 1 and 2, uranium-enriched zones are present primarily in basal conglomerate overlying fine-grained mudstone. In the black mudstone of the lower part of the Passaic Formation at sites 3, 4, and 5, uranium-enriched zones are black and white carbonate-rich siltstone and mudstone laminae overlying fine-grained black or gray mudstone. In the red mudstone of the Passaic Formation at site 6, which contains little uranium, the highest gamma counts were nevertheless obtained at the contact between a coarsegrained basal sandstone and the massive mudstone capping the fining-upward sequence beneath it. This result indicates that the location of low-level uranium enrichment in the red mudstone and siltstone of the lower part of the Passaic Formation is stratigraphically similar to that of the highly enriched zones in the arkose of the Stockton Formation and the black mudstone of the lower part of the Passaic Formation.

Caliper, BHTV, spontaneous-potential, and single-point-resistance logs and results of examination of cores clearly demonstrate that fracture density in all three lithologies is much higher within 75 to $125 \mathrm{ft}$ of land surface than at greater depths. Fracture density generally decreases with depth, as does the ratio of open to sealed fractures. Therefore, radioactive strata at shallow depths are much more likely to affect the radionuclide content of circulating water than radioactive strata at depths below 75 to $125 \mathrm{ft}$. 
Ground water over a large area is more likely to be radioactive where strata composed of radioactive rocks are continuous than where these strata are discontinuous or are found as isolated zones. Radioactive strata in the black mudstones of the lower part of the Passaic Formation were found to be laterally continuous along bedding planes as a result of their deposition in an environment consisting of extensive lakes. In the arkosic sandstones and the conglomerates of the Stockton Formation, however, radioactive strata are lenticular and discontinuous or exhibit significant variations in thickness over short distances as a result of their deposition in a fluvial-deltaicbeach environment. The continuity of radioactive strata in the black mudstones mapped during this study is consistent with results of previous work conducted in the Newark Basin.

Regional fracture patterns, including the density, depth, orientation, and continuity of fractures, affect concentrations of radioactivity in ground water; only circulating water channeled along fractures that intersect radioactive strata can dissolve large amounts of radionuclides from the rock matrix. Geophysical logs obtained during this study show that zones of water flow in both the black and red mudstone of the lower part of the Passaic Formation and the arkose and conglomerate of the Stockton Formation are most likely to be found in rocks that are intersected by large bedding-plane fractures (which may have significant lateral continuity) and in intervals where bedding-plane fractures and low- to moderately-dipping fractures form a complex interconnected fracture network that is a good conduit for water movement. Analysis of geophysical logs and examination of cores showed that the number of possible water-bearing fractures, the depth of the regolith and the highly fractured transition zone, and the depth of strata with dense fracturing are greater in the red mudstone of the Passaic Formation than in the black and gray mudstone of the lower part of the Passaic Formation. The arkose of the Stockton Formation has fracture characteristics generally similar to that of the red mudstone in the Passaic Formation, characterized by the presence of nearly horizontal bedding-plane fractures interconnected with steeply dipping regional fracture sets in possible water-bearing zones, as documented with BHTV. Well yicld from the arkose and red mudstone is generally moderate to high. More of the fractures in the black mudstone than in the arkose and red mudstone are high-angle or vertical with little evidence of water flow. Open horizontal fractures are slightly less common in the black mudstone than in the arkose or red mudstone and are often separated by massive unfractured strata, as at sites 3 and 4; thus the fracture networks in the black mudstone likely represent small local flow systems poorly connected to a larger regional flow system. Thercfore, well yield from the black mudstone and, consequently, the likelihood that significant volumes of circulating water will come in contact with radioactive rocks, is low. Results of water-quality analyses illustrate that wells, such as those at sites 3 and 4, penetrating poorly fractured, highly radioactive strata in the black mudstone often yicld water that contains low concentrations of radionuclides, unless the radioactive strata itself is significantly fractured and is intercepted by a water-bearing zone, in which case the water may contain very high concentrations of radionuclides (such as in well 19-250). Conversely, wells that intersect the densely fractured (with bedding-plane fractures and high-angle regional fracture sets that likely are connected to a large-scale flow system) radioactive strata in the arkose of the Stockton Formation are likely to produce water that contains high concentrations of radionuclides, even though the frequency of radioactive beds may be lower than in the black mudstone. 
Calcium is the dominant cation and bicarbonate is the dominant anion in most of the water samples, indicating that water quality is controlled predominantly by water-rock interaction resulting in the dissolution of calcite, which is prevalent in fractures and in nodules throughout the rocks of the Newark Basin. The concentrations of calcium and bicarbonate were lower in water samples from the Stockton Formation than in those from the Passaic Formation because calcite is less abundant in the former than in the latter. High concentrations of sodium and chloride in a few samples (as much as 87 and $230 \mathrm{mg} / \mathrm{L}$, respectively) likely result from human activities, such as road salting. High concentrations of calcium and bicarbonate (as much as 110 and $236 \mathrm{mg} / \mathrm{L}$, respectively) in the same water samples, however, are evidence of the importance of water-rock interaction in determining water quality.

Concentrations of dissolved trace elements and radioactivity are also representative of the composition of the surrounding bedrock. Concentrations of the trace elements lithium and strontium were higher in water samples from the black mudstone, in which these elements are present in high concentrations, than in samples from arkose, in which they are less common. The highest concentration of gross alpha-particle activity $(66.4 \mathrm{pCi} / \mathrm{L})$ was measured in the water sample obtained from the well penetrating the most radioactive rocks. Gross alpha-particle activity was low in samples of water that were collected from wells in which water-bearing fractures did not intersect radioactive rocks or were from areas in which no radioactive strata are present.

The concentrations of dissolved, chemically reactive radionuclides, such as those of uranium and radium, are also controlled by the geochemical environment of the ground water, which is in turn controlled by the composition of the surrounding rocks. In the Newark Basin, uranium isotopes are the dominant alpha-emitting radionuclides in oxidizing ground water, whereas ${ }^{226} \mathrm{Ra}$ is the dominant alpha-emitting radionuclide in reducing ground water. Water in the red mudstone of the Passaic Formation is oxidizing because organic matter, pyrite, and ferrous-iron-bearing minerals are generally absent; therefore, uranium isotopes are the dominant alpha-emitting radionuclides in water in this rock type. Water in the black mudstone of the lower part of the Passaic Formation is typically suboxic (reducing) because organic matter, pyrite, and silicate minerals bearing ferrous iron are common; therefore, uranium is insoluble and ${ }^{226} \mathrm{Ra}$ is the dominant alpha-emitting radionuclide in water in this rock type. The organic matter, pyrite, and ferrous-iron-bearing mineral content of the arkose of the Stockton Formation varies greatly. Consequently, both oxidizing and reducing water are present, and both uranium and radium can be present in detectable concentrations in water samples from the same borehole.

The recurrence of highly uranium-enriched zones in the coarsest sediment at the interface between the cyclic fining-upward depositional sequences of the arkosic Stockton Formation and the black and red mudstone of the lower part of the Passaic Formation can result in the presence of water with high concentrations of dissolved natural radionuclides. The well-connected bedding-plane and regional high-angle fracture sets in the Stockton Formation and a thick regolith and transition zone result in a productive aquifer with a strong likelihood that radioactive strata are intercepted by water-bearing fractures. In the lower part of the Passaic Formation, the regolith is thin in many places, and local high-angle fracture sets, commonly separated by thick intervals of unfractured rock, are abundant. Few of the fracture zones contain water; hence, in many cases, radioactive strata do not come in contact with water. Nevertheless, when one of the radioactive zones is intercepted by a water-bearing bedding-plane fracture, very high concentrations of dissolved radionuclides can result. 


\section{REFERENCES CITED}

American Geological Institute, 1976, Dictionary of geological terms (rev. ed.): Garden City, New York, Anchor Books, $472 \mathrm{p}$.

Ames, L.L., McGarrah, J.E., Walker, B.A., and Sutter, P.F., 1983, Uranium and radium sorption on amorphous ferric oxyhydroxide: Chemical Geology, v. 40, p. 135-148.

Arbogest, B.F., 1990, Quality assurance manual for the Branch of Geochemistry: U.S. Geological Survey Open-File Report 90-668, 174 p.

Bell, Christy, 1983, Radioactive mineral occurrences in New Jersey: New Jersey Geological Survey Open-File Report 83-5, 22 p.

Berner, R.A., 1981, A new geochemical classification of sedimentary environments: Journal of Sedimentary Petrology, v. 51, no. 2, p. 359-365.

Blatt, H., Middleton, G., and Murray, R., 1980, Origin of sedimentary rocks (2d ed.): Englewood Cliffs, N. J., Prentice-Hall, 782 p.

Claassen, H.C., 1982, Guidelines and techniques for obtaining water samples that accurately represent the water chemistry of an aquifer: U.S. Geological Survey Open-File Report 82-1024, $49 \mathrm{p}$.

Cochran, J.K., Carey, A.E., Sholkovitz, E.R., and Surprenant, L.D., 1986, The geochemistry of uranium and thorium in coastal marine sediments and sediment pore waters: Geochimica Cosmochimica Acta, v. 50, p. 663-680.

Cothern; C.R., 1987, Estimating the health risks of radon in drinking water: American Water Works Association Journal, v. 79, no. 4, p. 153-158.

Davison, C.C., Keys, W.S., and Paillet, F.L., 1982, Use of borehole-geophysical logs and hydrologic tests to characterize crystalline rock for nuclear-waste storage, Whiteshell Nuclear Research Establishment, Manitoba, and Chalk River Nuclear Laboratory, Ontario, Canada: Columbus, Ohio, Battelle Project Management Division Office of Nuclear Waste Isolation Technical Report 418, 103 p. (Available from National Technical Information Service, U.S. Department of Commerce, Springfield, VA 22161, as ONWI-418).

Dean, W.E., 1988, Inorganic geochemistry of fine-grained sedimentary rocks and hornfels in the Newark Supergroup, in Froelich, A.J., and Robinson, G.R., Jr., eds., Studies of the Early Mesozoic basins of the eastern United States: U.S. Geological Survey Bulletin 1776, p. 79-85.

Driscoll, F.G., 1986, Groundwater and wells (2d ed.): St. Paul, Minn., Johnson Filtration Systems, Inc., $1089 \mathrm{p}$.

Durrance, E.M., 1986, Radioactivity in geology: Principles and applications: Chichester, West Sussex, England, John Wiley and Sons, $441 \mathrm{p}$.

Faure, Gunter, 1977, Principles of isotope geology: New York, John Wiley and Sons, 464 p. 


\section{REFERENCES CITED--Continued}

Fenneman, N.M., 1938, Physiography of the eastern United States: New York, McGraw-Hill Book Co., Inc., 714 p.

Fertl, W.H., 1979, Gamma ray spectral data assists in complex formation evaluation: The Log Analysts, v. 20, no. 5, p. 3-37.

Fishman, L.C., and Friedman, L.C., 1989, Methods for determination of inorganic substances in water and fluvial sediments ( $3 \mathrm{~d}$ ed.): Techniques of Water-Resources Investigations of the U.S. Geological Survey, book 5, chap. A1, 545 p.

Froelich, A.J., and Olsen, P.E., 1985, Newark Supergroup, a revision of the Newark Group in eastern North America, in Robinson, G.R., and Froelich, A.J., eds., Proceedings of the second U.S. Geological Survey workshop on the Early Mesozoic basins of the eastern United States: U.S. Gcological Survey Circular 946, p. 1-3.

Geological Society of America, 1948, Rock-color chart: Reprinted 1984, The Netherlands, Huyskes-Enschede, 1 p.

Harned, D.A., 1989, The hydrogeologic framework and reconnaissance of ground-water quality in the Piedmont Province of North Carolina, with a design for future study: U.S. Geological Survey Water-Resources Investigations Report 88-4130, 55 p.

Hem, J.D., 1985, Study and interpretation of the chemical characteristics of natural water (3d ed.): U.S. Geological Survey Water-Supply Paper 2254, 263 p.

Hendry, M.J., 1988, Do isotopes have a place in ground-water studies?: Ground Water, v. 26, no. 4, p. 410-415.

Hess, A.E., 1982, A heat-pulse flowmeter for measuring low velocities in boreholes:

U.S. Geological Survey Open-File Report 82-699, 39 p.

Houghton, H.F., 1990, Hydrogeology of the Early Mesozoic rocks of the Newark Basin, New Jersey, in Brown, J. O., and Kroll, R. L., eds., Aspects of groundwater in New Jersey: Seventh annual meeting of the Geological Association of New Jersey, Kean College, Union, New Jersey, p. E1-E36.

Kasabach, H.F., 1966, Geology and groundwater resources of Hunterdon County, New Jersey: New Jersey Department of Conservation and Economic Development, Special Report 24, $128 \mathrm{p}$.

Keys, W.S., 1990, Borehole geophysics applied to ground-water investigations: U.S. Geological Survey Techniques of Water-Resources Investigations, book 2, chap. E2, $150 \mathrm{p}$.

Keys, W.S., and MacCary, L.M., 1971, Application of borehole geophysics to water-resources investigations: U.S. Geological Survey Techniques of Water-Resources Investigations, book 2, chap. E1, $126 \mathrm{p}$. 


\section{REFERENCES CITED--Continued}

Krieger, H.L., and Whittaker, E.L., 1980, Prescribed procedures for measurement of radioactivity in drinking water: U.S. Environmental Protection Agency Manual EPA-600/4-80-032, $111 \mathrm{p}$.

Lewis, J.C., and Spitz, F.J., 1987, Hydrology, ground-water quality, and the possible effects of a hypothetical radioactive-water spill, Plainsboro Township, New Jersey: U.S. Geological Survey Water-Resources Investigations Report 87-4092, 45 p.

Lindburg, R.D., and Runnels, D., 1984, Ground water redox reactions: An analysis of equilibrium state applied to Eh measurements and geochemical modeling: Science, v. 225, p. 925-927.

Lyttle, P.T., and Epstein, J.B., 1987, Geologic map of the Newark $1^{\circ} \times 2^{\circ}$ quadrangle, New Jersey, Pennsylvania, and New York: U.S. Geological Survey Miscellaneous-Investigations Map I-1715, 2 sheets, 1:250,000.

Michalski, A., 1990, Hydrogeology of the Brunswick (Passaic) Formation and implications for ground water monitoring practice: Ground Water Monitoring Review, fall 1990, p. 134-143.

Muessig, K.W., and Houghton, H.F., 1988, Geological controls of radon hazards in the Newark Basin, in Husch, J.M., and Hozick, M.J., eds., Geology of the central Newark Basin, Fifth annual meeting of the Geologic Association of New Jersey, Rider College, Lawrenceville, New Jersey, p. 195-212.

Olsen, P.E., 1980, Triassic and Jurassic Formations of the Newark Basin, in Field studies of New Jersey geology and guide to field trips, 52nd annual meeting of the New York State Geological Association, p. 2-39.

Osmond, J.K., and Cowart, J.B., 1976, The theory and uses of natural uranium isotopic variations in hydrology: Atomic Energy Review, v. 14, no. 4, p. 621-679.

Pettijohn, F.J., 1963, Data of geochemistry: Chapter S., Chemical composition of sandstonesexcluding carbonate and volcanic sands (6th ed.): U.S. Geological Survey Professional Paper 440-S, 19 p.

Prichard, H.M., and Gesell, T.F., 1977, Rapid measurements of Rn-222 concentrations in water with a commercial liquid scintillation counter: Health Physics, v. 33, p. 577.

Rima, D.R., 1955, Ground-water resources of the Lansdale area, Pennsylvania: Pennsylvania Geological Survey Progress Report 146, 24 p.

Rima, D.R., Meisler, H., and Longwill, S., 1962, Geology and hydrology of the Stockton Formation in southeastern Pennsylvania: Pennsylvania Geological Survey Bulletin W-14, 111 p.

Rogers, R.J., 1987, Geochemical evolution of groundwater in stratified-drift and arkosic bedrock aquifers in north central Connecticut: Water Resources Research, v. 23, no. 8, p. $1531-1545$. 


\section{REFERENCES CITED--Continued}

Schleien, J., and Terpilak, M.S., 1984, The health physics and radiological health handbook: Nucleon Lectern Association, $460 \mathrm{p}$.

Sloto, R.A., Macchiaroli, Paola, and Towle, M.T., 1992, Identification of a multiaquifer groundwater cross-continuation problem in the Stockton Formation by use of borehole geophysical methods, Hatboro, Pennsylvania, in Application of geophysics for engineering and environmental problems: Proceedings of the Society of Engineering and Mineral Exploration Geophysicists Conference, Oakbrook, Illinois, April 26-29, 1992, p. 21-35.

Snow, D.T., 1968, Rock fracture spacings, openings, and porosities: Journal of the Soil Mechanics and Foundations Division, Proceedings of the American Society of Civil Engineers, v. 94, no. SM1, p. 73-91.

Suchecki, R.K., Hubert, J.F., and Birney De Wet, C.C., 1988, Isotopic imprint of climate and hydrogeochemistry on terrestrial strata of the Triassic-Jurassic Hartford and Fundy rift basins: Journal of Sedimentary Petrology, v. 58, p. 801-811.

Szabo, Zoltan, and Zapecza, O.S., 1987, Relation between natural radionuclide activities and chemical constituents in ground water in the Newark Basin, New Jersey, in Graves, Barbara, ed., Radon, radium, and other radioactivity in ground water - Hydrogeologic impact and application to indoor airborne contamination: Proceedings of the National Water Well Association Conference, April 7-9, 1987, p. 283-308.

Taylor, T.A., 1989, Correlation of abnormal gamma readings with fluid movement through fractures in a formation by use of gamma-spectral logs, in Proceedings of the Third International Symposium on Borehole Geophysics for Minerals, Geotechnical, and Ground-Water Applications: Las Vegas, Nevada, The Minerals and Geotechnical Logging Society, v. 2, p. 471-499.

Thatcher, L.L., Janzer, V.J., and Edwards, K.W., 1977, Methods for determination of radioactive substances in water and fluvial sediments: U.S. Geological Survey Techniques of WaterResources Investigations, book 5, chap. A5, 95 p.

Turner-Peterson, C.E., 1977, Uranium mineralization during early burial, Newark Basin, Pennsylvania-New Jersey, in Campbell, J. A., ed., Short papers of the U.S. Geological Survey Uranium-Thorium Symposium: U.S. Geological Survey Circular 753, p. 3-4.

1980, Sedimentology and uranium mineralization in the Triassic-Jurassic Newark Basin, Pennsylvania and New Jersey, in Turner-Peterson, C.E., ed., Uranium in sedimentary rocks: Application of the facies concept to exploration, Society of Economic Paleontologists and Mineralogists short course notes, p. 149-175.

1988, A comparison of uranium-bearing sequences in the Newark Basin, Pennsylvania and New Jersey, and the San Juan Basin, New Mexico: U.S. Geological Survey Bulletin 1776, p. 350-356. 


\section{REFERENCES CITED--Continued}

Turner-Peterson, C.E., Olsen, P.E., and Nuccio, V.F., 1985, Modes of uranium occurrence in black mudstones in the Newark Basin, New Jersey and Pennsylvania: U.S. Geological Survey Circular 946, p. 120-124.

U.S. Environmental Protection Agency, 1978, Radon in water sampling program: U.S. Environmental Protection Agency EPA/EERF-Manual-78-1, p. 11.

1979, National secondary drinking water regulations: U.S. Code of Federal Regulations, Title 40, Part 143, Federal Register 44(144).

1991, National primary drinking water regulations; radionuclides, proposed rule: Federal Register, v. 56, p. 33050-33127.

1994, National primary drinking water standards: U.S. Environmental Protection Agency EPA 810-F-94-001A, 4 p.

U.S. Geological Survey, 1980, National handbook of recommended methods for water-data acquisition, Chapter 2, Ground Water, p. 2-85.

Van Houten, F.B., 1962, Cyclic sedimentation and the origin of analcime-rich Upper Triassic Lockatong Formation, west-central New Jersey and adjacent Pennsylvania: American Journal of Science, v. 260, p. 561-576.

1965, Composition of Triassic Lockatong and associated formations of Newark Group, central New Jersey and adjacent Pennsylvania: American Journal of Science, v. 263, p. 825-863.

1969, Late Triassic Newark Group, north-central New Jersey and adjacent Pennsylvania and New York, in Subitzky, Seymour, ed., Geology of selected areas in New Jersey and eastern Pennsylvania and guidebook of excursions: New Brunswick, N.J., Rutgers Univ. Press, p. 314-347.

1980, Late Triassic Part of Newark Supergroup, Delaware River section, west-central New Jersey, in Field studies of New Jersey geology and guide to field trips: $52 \mathrm{~d}$ annual meeting of the New York State Geological Association, p. 264-276.

Vecchioli, J., Carswell, L.D., and Kasabach, H.F., 1969, Occurrence and movement of ground water in the Brunswick Shale at a site near Trenton, New Jersey: U.S. Geological Survey Professional Paper 650-B, p. B154-B157.

Welch, A.H., Szabo, Zoltan, Parkhurst, D.L., VanMetre, P.C., and Mullin, A.H., 1995, Gross-beta activity in ground water: Natural sources and artifacts of sampling and laboratory analysis: Applied Geochemistry, v. 10, p. 491-503.

Wershaw, R.L., Fishman, M.J., Grabbe, R.R., and Lowe, L.E., 1987, Methods for the determination of organic substances in water and fluvial sediments: U.S. Geological Survey Techniques of Water-Resources Investigations, book 5, chap. A3, $80 \mathrm{p}$. 


\section{REFERENCES CITED--Continued}

Wood, W.W., 1976, Guidelines for collection and field analysis of ground-water samples for selected unstable constituents: U.S. Geological Survey Techniques of Water-Resources Investigations, book 1, chap. D2, 24 p.

Zapecza, O.S., and Szabo, Zoltan, 1987, Source and distribution of natural radioactivity in ground water in the Newark Basin, New Jersey, in Graves, Barbara, ed., Radon, radium, and other radioactivity in ground water--Hydrogeologic impact and application to indoor airborne contamination: Proceedings of the National Water Well Association Conference, Somerset, New Jersey, April 7-9, 1987, p. 47-68.

Zapecza, O:S., and Szabo, Zoltan, 1988, Natural radioactivity in ground water--A review: National Water Summary 1986--Hydrologic events and ground-water quality: U.S. Geological Survey Water-Supply Paper 2325, p. 50-57.

Zemanek, Joseph, Caldwell, R.L., Glenn Jr., E.E., Holcomb, S.V., Norton, L.J., and Straus, A.J.D., 1969, The borehole televiewer--A new logging concept for fracture location and other types of borehole inspection: Journal of Petroleum Technology, June 1969, v. 21, no. 6, p. $762-774$. 


\section{GLOSSARY}

Alpha particle. The nucleus of a helium atom emitted during the decay of some radioisotopes. Unlike gamma activity, not measured by well logging, because of very low penetrating ability.

Altitude. In this report, altitude refers to the distance above or below sea level.

Background radiation. The radioactivity that exists at the surface or in a well, in addition to the anomalous radioactivity that is being measured; surface background is derived from natural radioisotopes in the rocks and from cosmic radiation.

Beta particle. An electron (or positron) emitted from a nucleus of a radioisotope during beta decay. Capable of penetrating only a few millimeters of rock; hence, not measured during well logging.

Bioturbation. The churning and stirring of a sediment by organisms.

Borehole televiewer log. A record of the amplitude of high-frequency acoustic pulses reflected by the borehole wall; provides location and orientation of bedding, fractures, and cavities.

Caliper log. A continuous record of hole diameter, usually made with a mechanical probe having from one to six expandable arms.

Convoluted bedding. Sedimentary bedding planes that are severely crumpled.

Correlation. Determination of the position of stratigraphically equivalent rock units in different wells. Typically done by matching the character of geophysical logs, log response, and core characteristics (lithology, fossils).

Cross bedding. The arrangement of laminations of strata transverse or oblique to the main stratification planes.

Decay. The process of disintegration of an unstable radioisotope by the spontaneous emission of charged particles or photons.

Detector. Any kind of sensor used to detect a form of energy. Usually refers to nuclear detectors, such as scintillation crystals, used for gamma spectral measurements.

Deviation. The departure, in degrees, between the borehole axis and the vertical plane.

Diagenesis. The process of physical and chemical changes in an unconsolidated sediment, after deposition, that changes it into a consolidated rock.

Digital $\log$. A log recorded as a series of discrete numerical values.

Dip. The angle at which a stratum, or any planar feature, is inclined from the horizontal. The dip of a rock unit is perpendicular to the strike. 


\section{GLOSSARY--Continued}

Dissolved constituents. Chemical constituents in a water sample that pass through a 0.45 micrometer membrane filter. This is a convenient operational definition used by Federal agencies that collect water data. Determinations of "dissolved" constituents are made from subsamples of the filtrate.

Electron volt. The energy acquired by an electron passing through a potential difference of one volt $(\mathrm{eV})$; used to measure the energy of nuclear radiation and particles by gamma spectroscopy, commonly expressed as million electron volts $(\mathrm{MeV})$.

Element. Any substance identified by a specific number of protons in its nucleus (known as the atomic number) that cannot be separated into smaller component substances except by nuclear disintegration (radioactivity).

Field-measured characteristics. A phrase used to identify characteristics determined in the field when the water sample is collected. Water temperature, specific conductance, $\mathrm{pH}$, and dissolved-oxygen concentration are considered field-measured characteristics in this study.

Fissured zone. An interconnected network of extensive rock cracks or fractures too numerous to quantify by simple counting; generally, but not always, oriented in approximately the same direction; and ranging in vertical extent from several inches to several feet.

Formation. A body of rock strata characterized by distinct lithologic features.

Gamma log. A log of the natural radioactivity of the rocks penetrated by a borehole.

Gamma ray. A photon that has neither mass nor electrical charge that is emitted by the nucleus of a decaying radionuclide; measured by gamma logging.

Gamma spectral log. A log of gamma radiation as a function of its energy, which permits the identification of the radioisotopes present.

Ground electrode. A surface electrode used for spontaneous-potential and single-point-resistivity logging.

Ground water. Water that saturates soil, unconsolidated deposits, and (or) bedrock beneath the land surface.

Half-life. The time required for one-half of a given amount of a radioisotope to be lost through radioactivite decay.

Heat-pulse flowmeter. A logging device designed to measure the rate and direction of fluid movement in a well (vertical flow) on the basis of the rate of change in temperature of the water after heating a thermistor in the submerged probe.

Isotopes. Atoms of the same element that have the same atomic number, but a different mass number; unstable isotopes are radioactive and decay to become stable isotopes, possibly of a different element. 


\section{GLOSSARY--Continued}

Laminated bedding. Sedimentary strata, less than one centimeter thick, that are visually distinguishable from the layers above and below.

Matrix. The solid framework of rock or mineral grains that surrounds the pore spaces.

Maximum contaminant level. Maximum permissible level of a contaminant in water that is delivered to the free-flowing outlet of the ultimate user of a public water system.

Micrograms per liter $(\mu \mathrm{g} / \mathrm{L})$. A unit expressing the concentration of chemical constituents in solution as the mass (microgram $=1 \times 10^{-6}$ gram) of solute per unit volume (liter) of water. One thousand micrograms per liter is equivalent to one milligram per liter. One microgram per liter is approximately equal to 1 part per billion (ppb) in aqueous solutions of low dissolved-solids concentration.

Milliequivalent. A number used to express concentration in terms of charge; computed by multiplying the reported concentration of an individual ion, in milligrams per liter, by the valence charge of the ion and then dividing the result by the formula weight of the ion in grams.

Milligrams per liter (mg/L). A unit expressing the concentration of chemical constituents in solution as the mass (milligram) of solute per unit volume (liter) of water. One thousand micrograms per liter is equivalent to one milligram per liter. For water containing less than $7,000 \mathrm{mg} / \mathrm{L}$ dissolved solids, the numerical value for milligrams per liter of a constituent is the same as for concentrations in parts per million (ppm).

Minimum reporting limit. For a given type of sample and analytical procedure, the concentration below which the presence of the constituent being analyzed can be neither verified nor denied at a given level of confidence. Minimum reporting limits are identified in the tables of this report by a "less-than" $(<)$ symbol preceding a numerical value. The minimum reported limit can vary from analysis to analysis for any single constituent, depending on numerous chemical, physical, and other factors that affect the confidence of the analyst in the obtained result.

Mudcrack. Crack formed by the shrinkage of clay or clay-bearing beds in the course of drying.

Open hole. Uncased interval of a borehole or well.

Paleosol. A buried soil.

Picocurie. The unit of measurement of the quantity of any radionuclide that produces 2.2 disintegrations per minute.

Porosity. The ratio of the void volume of a porous rock to the total volume, commonly expressed as a percentage.

Probe. Downhole well-logging instrument package. 


\section{GLOSSARY--Continued}

Radioactivity. Energy emitted as particles or rays during the decay of an unstable isotope (radionuclide) to another unstable or stable isotope.

Radioactive-decay series. The series of radionuclides successively formed by the radioactive decay of a long-lived parent radionuclide before a stable isotope of a product element is formed.

Radionuclide. A specific isotope of an element that is radioactive (will undergo a form of radioactive decay).

Resistivity logs. Any of a large group of logs that are designed to make quantitative measurements of the specific resistance of a material to the flow of electric current.

Sabkha. A broad, supra-tidal surface or coastal flat bordering a lagoonal or inner shelf region. An essential feature of the sabkha is that it is flooded only occasionally.

Scintillation detector. An efficient detector used in nuclear-logging equipment; ionizing radiation causes flashes of light that are sensed by a photomultiplier tube and converted to pulses of electric current.

Secular equilibrium. In a radioactive decay series, the condition when the rate of decay of the progeny is equal to that of the parent. If this condition is not met, the total radioactivity measured for one radioisotope may not correctly indicate the quantity of other isotopes present from the same decay series (termed disequilibrium).

Sedimentary structure. Any physical feature in a sedimentary rock. Primary structures, such as cross beds, are formed at the time of deposition. Secondary structures, such as nodules or concretions, are formed after deposition.

Sensitivity. The amplitude of deflection of a $\log$ in response to a standard-input signal.

Signal. The desired portion of the response of a logging device as compared to the unwanted noise.

Single-point-resistance log. A single electrode device used to make qualitative measurements of resistance between an electrode in the well and an electrode at the land surface or between two electrodes in the well.

Specific conductance. A measure of the capacity of a water to conduct an electrical current, expressed in microsiemens per centimeter at 25 degrees Celsius.

Spike. A sharp deflection on a log.

Spontancous-potential log. A log of the difference in direct-current voltage between an electrode in a well and one at the surface; most of the voltage results from electrochemical potentials that develop between dissimilar borehole and formation fluids.

Strike. The direction of a horizontal line in the plane of an inclined stratum, joint, fault, cleavage plane, or any other structural plane. It is perpendicular to the dip. 


\section{GLOSSARY--Continued}

Styolite. An irregular, suture-like boundary developed in some sedimentary rocks that is generally independent of the bedding planes.

Temperature log. A log of the temperature of the fluids in a borehole with depth.

Trace fossil. A sedimentary structure consisting of a fossilized track, burrow, trail, tube, boring, or tunnel resulting from the life activities of an animal, such as the mark made by an invertebrate moving, creeping, feeding, hiding, browsing, running, or nesting on or in soft sediment. 


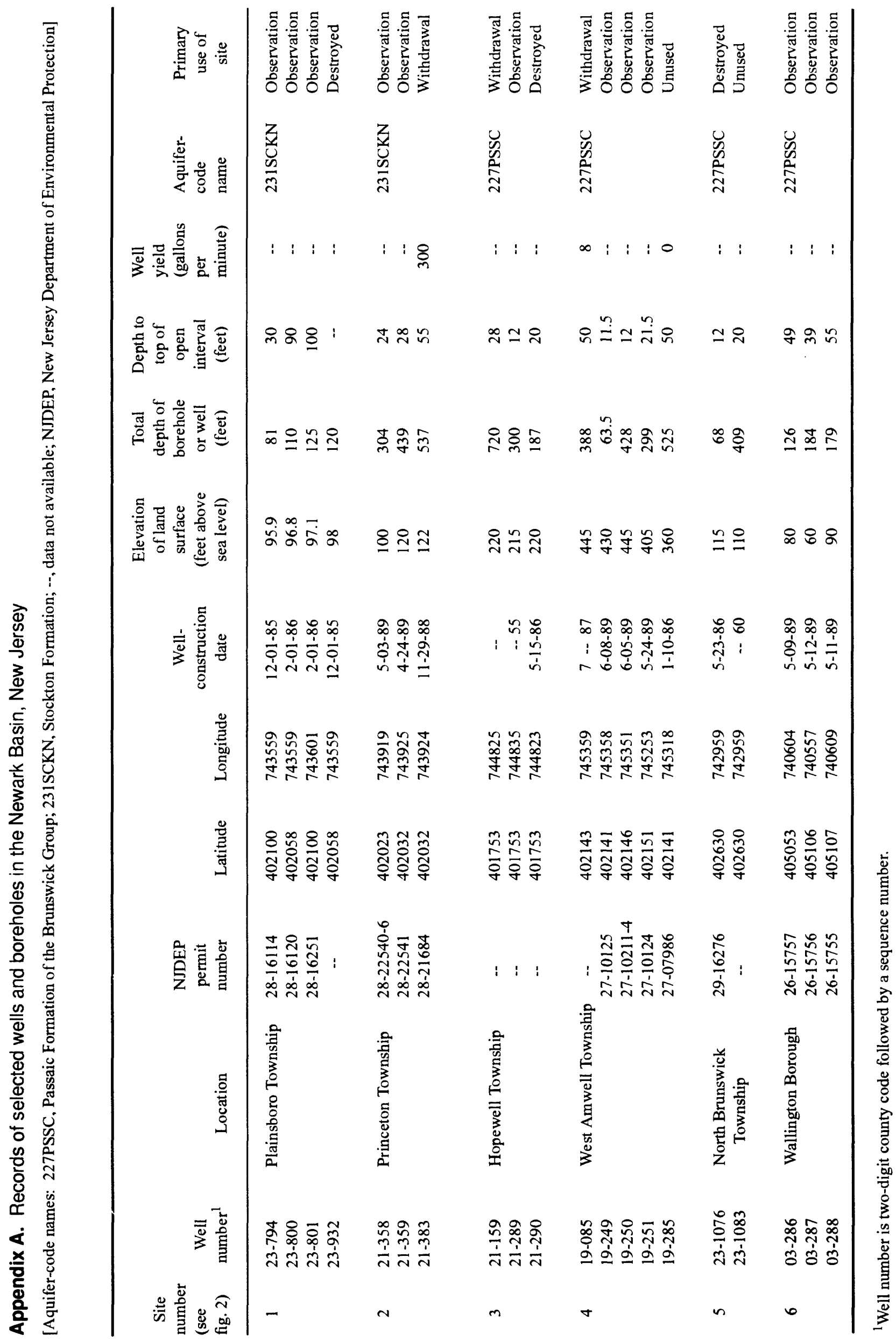


Appendix B-1. Major- and trace-element constituents of whole-rock samples from selected depths in three boreholes, south-central Newark Basin, New Jersey

[Constiluents determined by means of whole-rock hydrofluoric-acid-digested chemical analysis; reported laboratory precision \pm 2 percent; $\mathrm{ft}$, feet; $\mu \mathrm{g} / \mathrm{g}$, micrograms per gram; <, less than; stratigraphic location of samples shown on plates 1. 3, and 5]

\begin{tabular}{|c|c|c|c|c|c|c|c|c|c|c|c|}
\hline $\begin{array}{l}\text { Sample } \\
\text { depth } \\
\text { (fi) }\end{array}$ & $\begin{array}{l}\text { Sample } \\
\text { number }\end{array}$ & $\begin{array}{l}\text { Carbon. } \\
\text { inorganic } \\
\text { (percent) }\end{array}$ & $\begin{array}{c}\text { Carbon. } \\
\text { organic } \\
\text { (percent) }\end{array}$ & $\begin{array}{l}\text { Aluminum } \\
\text { (percent) }\end{array}$ & $\begin{array}{l}\text { Calcium } \\
\text { (percenl) }\end{array}$ & $\begin{array}{c}\text { Iron } \\
\text { (percent) }\end{array}$ & $\begin{array}{l}\text { Potassium } \\
\text { (percent) }\end{array}$ & $\begin{array}{c}\text { Magnesium } \\
\text { (percent) }\end{array}$ & $\begin{array}{c}\text { Sodium } \\
\text { (percent) }\end{array}$ & $\begin{array}{c}\text { Phosphorus } \\
\text { (percent) }\end{array}$ & $\begin{array}{l}\text { Tilanium } \\
\text { (percent) }\end{array}$ \\
\hline \multicolumn{12}{|c|}{ CORI: $23-932$} \\
\hline 9.5 & $1-1$ & $<0.01$ & 0.07 & 4.85 & 0.11 & 2.62 & 1.45 & $\begin{array}{r}0.28 \\
.22\end{array}$ & $\begin{array}{l}1.93 \\
1.09\end{array}$ & $\begin{array}{r}0.04 \\
.02\end{array}$ & $\begin{array}{l}0.6 \\
.08\end{array}$ \\
\hline 102.5 & $1-6$ & .24 & .18 & $\begin{array}{l}3.49 \\
17.0\end{array}$ & $\begin{array}{l}.93 \\
.42\end{array}$ & $\begin{array}{l}.92 \\
.65\end{array}$ & $\begin{array}{r}2.15 \\
.09\end{array}$ & $\begin{array}{l}.22 \\
.50\end{array}$ & .01 & .005 & .007 \\
\hline 102.6 & $1-7$ & .02 & $\begin{array}{l}.18 \\
.02\end{array}$ & $\begin{array}{c}17.0 \\
6.13\end{array}$ & $\begin{array}{l}.42 \\
.79\end{array}$ & $\begin{array}{r}.65 \\
2.27\end{array}$ & $\begin{array}{l}.09 \\
1.74\end{array}$ & .41 & 2.93 & .04 & .11 \\
\hline 110.6 & $1-8$ & .19 & .02 & 6.13 & & & & & & & \\
\hline
\end{tabular}

\section{LOWFR PART OF PASSAIC FORMATION}

CORE $21-290$

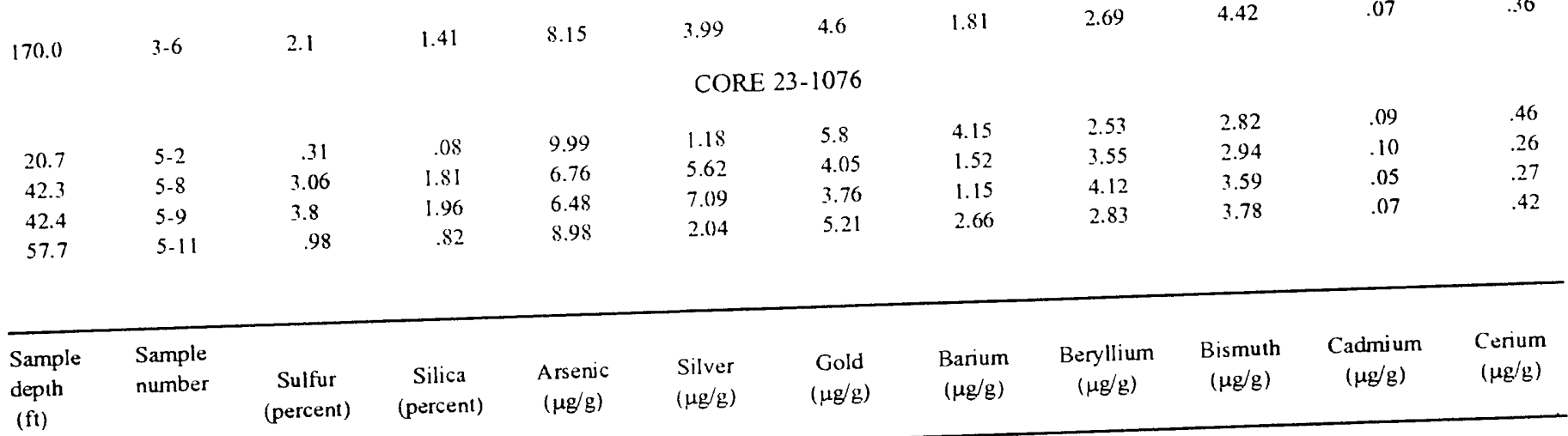

\section{STOCKTON FORMATION}

CORE 23-932

\begin{tabular}{|c|c|c|c|c|c|c|c|c|c|c|}
\hline 9.5 & $1-1$ & $<0.05$ & 78.68 & $<10$ & $<2$ & $<8$ & 292 & 2 & $<10$ & $<2$ \\
\hline 102.5 & $1-6$ & $<.05$ & 83.01 & $<10$ & $<2$ & $<8$ & 632 & $<1$ & $<10$ & $<2$ \\
\hline 102.6 & $1-7$ & .31 & 63.05 & 10 & $<2$ & $<8$ & 49 & 3 & $<10$ & $<2$ \\
\hline 110.6 & $1-8$ & $<.05$ & 72.26 & $<10$ & $<2$ & $<8$ & 224 & 1 & $<10$ & $<2$ \\
\hline
\end{tabular}

\section{LOWER PART OF PASSAIC FORMATION}

CORE 21-290

$\begin{array}{llllllc}170.0 & 3-6 & 1.23 & 69.17 & 240 & <2 & <8 \\ & & & & & & \text { CORE 23-1076 }\end{array}$

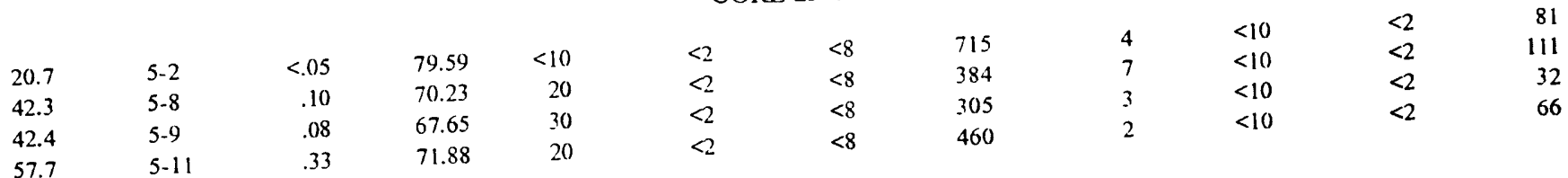


Appendix B-1. Major- and trace-element constituents of whole-rock samples from selected depths in three boreholes, south-central Newark Basin, New Jersey--Continued

\begin{tabular}{|c|c|c|c|c|c|c|c|c|c|c|c|}
\hline $\begin{array}{l}\text { Sample } \\
\text { depth } \\
\text { (fi) }\end{array}$ & $\begin{array}{l}\text { Sample } \\
\text { number }\end{array}$ & $\begin{array}{l}\text { Cobalt } \\
(\mu \mathrm{g} / \mathrm{g})\end{array}$ & $\begin{array}{c}\text { Chromium } \\
(\mu \mathrm{g} / \mathrm{g})\end{array}$ & $\begin{array}{l}\text { Copper } \\
(\mu \mathrm{g} / \mathrm{g})\end{array}$ & $\begin{array}{c}\text { Europium } \\
(\mu \mathrm{g} / \mathrm{g})\end{array}$ & $\begin{array}{c}\text { Gallium } \\
(\mu \mathrm{g} / \mathrm{g})\end{array}$ & $\begin{array}{c}\text { Holmium } \\
(\mu \mathrm{g} / \mathrm{g})\end{array}$ & $\begin{array}{c}\text { Lanthanum } \\
(\mu \mathrm{g} / \mathrm{g})\end{array}$ & $\begin{array}{c}\text { Lithium } \\
(\mu g / g)\end{array}$ & $\begin{array}{c}\text { Manganese } \\
(\mu \mathrm{g} / \mathrm{g})\end{array}$ & $\begin{array}{l}\text { Molyb- } \\
\text { denum } \\
(\mu \mathrm{g} / \mathrm{g})\end{array}$ \\
\hline
\end{tabular}

\section{STOCKTON FORMATION}

CORE 23-932

$\begin{array}{rrrrrrrrrrrr}9.5 & 1-1 & 8 & 86 & 137 & <2 & 12 & <4 & 106 & 6 & 112 & <2 \\ 102.5 & 1-6 & 3 & 100 & 126 & <2 & 7 & <4 & 20 & 3 & 270 & <2 \\ 102.6 & 1-7 & 5 & <1 & 8 & <2 & 14 & <4 & <2 & 11 & 54 & <2 \\ 110.6 & 1-8 & 7 & 37 & 3 & <2 & 15 & <4 & 29 & 11 & 403 & <2\end{array}$

\section{LOWER PART OF PASSAIC FORMATION}

CORE 21-290

\begin{tabular}{|c|c|c|c|c|c|c|c|c|c|c|c|}
\hline 170.0 & $3-6$ & 21 & 113 & 51 & $<2$ & 23 & $<4$ & 36 & 38 & 1,030 & 102 \\
\hline \multicolumn{12}{|c|}{ CORE 23-1076 } \\
\hline 20.7 & $5-2$ & 28 & 161 & 3 & $<2$ & 27 & $<4$ & 45 & 135 & 454 & 4 \\
\hline 42.3 & $5-8$ & 10 & 71 & 60 & 4 & 30 & $<4$ & 40 & 53 & 1.640 & 87 \\
\hline 42.4 & $5-9$ & 13 & 64 & 42 & $<2$ & 17 & $<4$ & 21 & 45 & 1.520 & 116 \\
\hline 57.7 & $5-11$ & 25 & 108 & 53 & $<2$ & 26 & $<4$ & 39 & 67 & 625 & 6 \\
\hline $\begin{array}{l}\text { Sample } \\
\text { depth } \\
\text { (ft) }\end{array}$ & $\begin{array}{l}\text { Sample } \\
\text { number }\end{array}$ & $\begin{array}{c}\text { Niobium } \\
(\mu g / g)\end{array}$ & $\begin{array}{c}\text { Neodymium } \\
(\mu \mathrm{g} / \mathrm{g})\end{array}$ & $\begin{array}{l}\text { Nickel } \\
(\mu \mathrm{g} / g)\end{array}$ & $\begin{array}{c}\text { Lead } \\
(\mu \mathrm{g} / \mathrm{g})\end{array}$ & $\begin{array}{c}\text { Scandium } \\
(\mu \mathrm{g} / \mathrm{g})\end{array}$ & $\begin{array}{c}\operatorname{Tin} \\
(\mu \mathrm{g} / \mathrm{g})\end{array}$ & $\begin{array}{c}\text { Sirontium } \\
(\mu \mathrm{g} / \mathrm{g})\end{array}$ & $\begin{array}{c}\text { Tantalum } \\
(\mu \mathrm{g} / \mathrm{g})\end{array}$ & $\begin{array}{c}\text { Thorium } \\
(\mu \mathrm{g} / \mathrm{g})\end{array}$ & $\begin{array}{c}\text { Uranium } \\
(\mu \mathrm{g} / \mathrm{g})\end{array}$ \\
\hline
\end{tabular}

\section{STOCKTON FORMATION}

CORE 23-932

\begin{tabular}{|c|c|c|c|c|c|c|c|c|c|c|}
\hline 9.5 & $1-1$ & 11 & 86 & 19 & 9 & 7 & $<10$ & 36 & $<40$ & ${ }^{1} 42$ \\
\hline $1(1) 2.5$ & $1-6$ & $<4$ & 16 & 10 & 8 & 2 & $<10$ & 49 & $<40$ & ${ }^{1} 5$ \\
\hline 110.6 & $1-8$ & $<4$ & 23 & 10 & 7 & 5 & $<10$ & 44 & $<40$ & ${ }^{19} 9$ \\
\hline
\end{tabular}

\section{LOWER PART OF PASSAIC FORMATION}

\section{CORE $21-290$}

\begin{tabular}{|c|c|c|c|c|c|c|c|c|c|c|c|}
\hline 170.0 & $3-6$ & 8 & 31 & 42 & 46 & 14 & $<10$ & 325 & $<40$ & 11 & 300 \\
\hline \multicolumn{12}{|c|}{ CORE 23-1076 } \\
\hline 20.7 & $5-2$ & 14 & 37 & 57 & 24 & 18 & $<10$ & 240 & $<40$ & ${ }^{1} 15$ & ${ }^{1} 1.6$ \\
\hline 42.4 & $5-9$ & $<4$ & 18 & 27 & 29 & 11 & $<10$ & 755 & $<40$ & 7 & 100 \\
\hline 57.7 & $5-11$ & 12 & 34 & 49 & 18 & 13 & $<10$ & 291 & $<40$ & ${ }^{1} 17$ & ${ }^{1} S .0$ \\
\hline
\end{tabular}

${ }^{1}$ Determined by delayed nuclear activation analysis. 
Appendix B-1. Major- and trace-element constituents of whole-rock samples from selected depths in three boreholes, south-central Newark Basin, New Jersey--Continued

\begin{tabular}{rrrrrr}
$\begin{array}{c}\text { Sample } \\
\text { depth } \\
(\mathrm{ft})\end{array}$ & $\begin{array}{c}\text { Sample } \\
\text { number }\end{array}$ & $\begin{array}{c}\text { Vanadium } \\
(\mu \mathrm{g} / \mathrm{g})\end{array}$ & $\begin{array}{c}\text { Yttrium } \\
(\mu \mathrm{g} / \mathrm{g})\end{array}$ & $\begin{array}{c}\text { Ytterbium } \\
(\mu \mathrm{g} / \mathrm{g})\end{array}$ & $\begin{array}{r}\text { Zinc } \\
(\mu \mathrm{g} / \mathrm{g})\end{array}$ \\
\multicolumn{5}{c}{ STOCKTON FORMATION } \\
9.5 & $1-1$ & 51 & 36 & 4 & 20 \\
102.5 & $1-6$ & 25 & 6 & $<1$ & 5 \\
102.6 & $1-7$ & 3 & $<2$ & $<1$ & $<2$ \\
110.6 & $1-8$ & 42 & 10 & 1 & 10
\end{tabular}

\section{LOWER PART OF PASSAIC FORMATION}

CORE 21-290

170.0

$3-6$

178

25

3

96

CORE 23-1076

$\begin{array}{rrrrrr}20.7 & 5-2 & 99 & 22 & 3 & 145 \\ 42.3 & 5-8 & 266 & 99 & 10 & 64 \\ 42.4 & 5-9 & 188 & 11 & 1 & 37 \\ 57.7 & 5-11 & 159 & 21 & 2 & 96\end{array}$


Appendix B-2. Results of gamma-spectrometric analyses for uranium, thorium, potassium, and gross gamma, and hydrofluoric-acid digested whole-rock chemical analyses for uranium in rock samples from selected depths in three boreholes, south-central Newark Basin, New Jersey

[Reported laboratory precision is the greater of the following: \pm 10 percent of the reported value or $\pm 2 \mathrm{ppm}$ for equivalent uranium, $\pm 5 \mathrm{ppm}$ for equivalent thorium, \pm 0.5 percent for potassium, and $\pm 0.1 \mathrm{ppm}$ for gross gamma; ppm, parts per million; NA, not applicable; <, less than; stratigraphic location of samples shown on plates 1, 3, and 5]

\begin{tabular}{llccccc}
\hline $\begin{array}{c}\text { Sample } \\
\text { depth } \\
\text { (feet below }\end{array}$ & $\begin{array}{c}\text { Sample } \\
\text { land surface) }\end{array}$ & $\begin{array}{c}\text { Uranium } \\
\text { (fluorometric) } \\
\text { number }\end{array}$ & $\begin{array}{c}\text { Equivalent } \\
\text { uranium } \\
(\mathrm{ppm})\end{array}$ & $\begin{array}{c}\text { Equivalent } \\
\text { thorium } \\
(\mathrm{ppm})\end{array}$ & $\begin{array}{c}\text { Potassium } \\
\text { (percent) }\end{array}$ & $\begin{array}{c}\text { Gross gamma } \\
\text { (as equivalent } \\
\text { uranium, in } \\
\text { inm) }\end{array}$ \\
\hline
\end{tabular}

\section{STOCKTON FORMATION}

CORE 23-932

\begin{tabular}{|c|c|c|c|c|c|c|}
\hline 9.5 & ${ }^{1} 1-1$ & 4.2 & 8.0 & 37 & 1.4 & 27.2 \\
\hline 25.0 & $1-2$ & 1.0 & 2.0 & 16 & 7.6 & 15.5 \\
\hline 40.1 & $1-3$ & 23 & 23 & $<5.0$ & 2.2 & 25.8 \\
\hline 100.5 & $1-4$ & 4.9 & 5.0 & $<5.0$ & 2.1 & 10.4 \\
\hline 102.0 & $1-5$ & 5.6 & 11 & 8.0 & 2.3 & 15.2 \\
\hline 102.5 & ${ }^{1} 1-6$ & 7.1 & 12 & $<5.0$ & 2.4 & 16.6 \\
\hline 102.6 & ${ }^{1} 1-7$ & 4.1 & 15 & $<20$ & $<2.0$ & 16.5 \\
\hline 110.6 & $1-8$ & 3.6 & 4.0 & 7.0 & 1.9 & 9.5 \\
\hline 116.7 & $1-9$ & 4.5 & 5.0 & 7.0 & 1.6 & 10.4 \\
\hline
\end{tabular}

\section{LOWER PART OF PASSAIC FORMATION}

\begin{tabular}{|c|c|c|c|c|c|c|}
\hline \multirow[b]{2}{*}{111.0} & & & & & & \\
\hline & $3-1$ & 1.3 & $<2.0$ & 11 & 4.8 & 9.0 \\
\hline 122.9 & $3-2$ & 1.3 & 2.0 & 9.0 & 3.3 & 10.1 \\
\hline 141.5 & $3-3$ & 140 & 145 & 10 & 1.8 & 143 \\
\hline 141.8 & ${ }^{1} 3-4$ & 200 & 200 & 13 & 1.8 & 230 \\
\hline 159.6 & $3-5$ & 12 & 13 & 7.0 & 3.8 & 19.9 \\
\hline 170.0 & $3-6$ & 240 & 230 & 5.0 & 2.4 & 223 \\
\hline 170.1 & ${ }^{13-7}$ & 300 & 255 & 13 & 2.6 & 304 \\
\hline \multirow[t]{2}{*}{178.0} & $3-8$ & 3.9 & 7.0 & 12 & 2.3 & 12.6 \\
\hline & \multicolumn{6}{|c|}{ CORE 23-1076 } \\
\hline 12.2 & $5-1$ & 1.3 & 2.0 & 10 & 2.6 & 11.4 \\
\hline 20.7 & $5-2$ & .9 & $<2.0$ & 16 & 4.7 & 10.9 \\
\hline 24.5 & $5-3$ & .8 & 2.0 & 11 & 2.2 & 8.4 \\
\hline 32.4 & $5-4$ & .5 & $<2.0$ & 5.0 & 3.5 & 7.3 \\
\hline 38.0 & ${ }^{1} 5-5$ & .6 & 2.0 & 7.0 & 1.4 & 9.1 \\
\hline 38.6 & $5-6$ & .7 & $<2.0$ & 13 & 1.4 & 7.2 \\
\hline 42.0 & $5-7$ & 19 & 280 & 6.0 & 1.8 & 226 \\
\hline 42.3 & $1_{5-8}$ & 6,200 & 1,740 & $<5.0$ & 2.7 & 2,580 \\
\hline 42.4 & ${ }^{1} 5-9$ & 100 & 540 & $<5.0$ & 1.4 & 513 \\
\hline 54.7 & $5-10$ & 1.2 & 4.0 & 9.0 & 3.5 & 10.6 \\
\hline 57.7 & $5-11$ & 7.2 & 11 & 12 & 2.8 & 16.7 \\
\hline
\end{tabular}

QUALITY ASSURANCE SAMPLES WITH KNOWN URANIUM AND THORIUM CONCENTRATIONS

\begin{tabular}{lrcrrrrr} 
NA & ${ }^{2}$ QA-1 & 4.0 & 13 & 25 & 1.8 & 21.3 \\
NA & 1,3 QA-2 & 85 & 110 & 155 & 2.8 & 184 \\
\hline
\end{tabular}

\footnotetext{
${ }^{1}$ Precision, accuracy, and lower detection limits for these gamma-spectrometric analyses were limited by the small amount of sample available.

${ }^{2}$ Known uranium concentration (8.1 ppm); thorium concentration (29.7 ppm).

${ }^{3}$ Known uranium concentration (93 ppm); thorium concentration (199 ppm).
} 
Appendix C. Physical properties of, and concentrations of major ions, nutrients, trace elements, radioactive elements, and purgeable organic compounds in, water samples from boreholes or wells adjacent to boreholes, Newark Basin, New Jersey, 1985-1991

$\left[{ }^{\circ} \mathrm{C}\right.$, degrees Celsius; $\mu \mathrm{S} / \mathrm{cm}$, microsiemens per centimeter at $25^{\circ} \mathrm{C} ; \mu \mathrm{g} / \mathrm{L}$, micrograms per liter; $\mathrm{mg} / \mathrm{L}$, milligrams per liter; pCi/L, picocuries per liter; Am-241, americium-241; Cs-137, cesium-137; --, data not available; <, less than]

\begin{tabular}{|c|c|c|c|c|c|c|c|c|c|c|c|}
\hline $\begin{array}{c}\text { Well } \\
\text { number }\end{array}$ & $\begin{array}{c}\text { Date } \\
\text { of } \\
\text { sampling }\end{array}$ & $\begin{array}{c}\text { Time } \\
\text { of } \\
\text { sampling }\end{array}$ & $\begin{array}{c}\text { Water } \\
\text { temper- } \\
\text { ature, } \\
\left({ }^{\circ} \mathrm{C}\right)\end{array}$ & $\begin{array}{c}\text { Spe- } \\
\text { cific } \\
\text { conduc- } \\
\text { tance } \\
(\mu \mathrm{S} / \mathrm{cm})\end{array}$ & $\begin{array}{c}\text { Spe- } \\
\text { cific } \\
\text { conduc- } \\
\text { tance, lab } \\
(\mu \mathrm{S} / \mathrm{cm})\end{array}$ & $\begin{array}{c}\text { Oxygen, } \\
\text { dis- } \\
\text { solved } \\
(\mathrm{mg} / \mathrm{L})\end{array}$ & $\begin{array}{c}\mathrm{pH}, \\
\text { field } \\
\text { (standard } \\
\text { units) }\end{array}$ & $\begin{array}{c}\text { Alka- } \\
\text { linity, } \\
\text { total field } \\
(\mathrm{mg} / \mathrm{L} \text { as } \\
\left.\mathrm{CaCO}_{3}\right)\end{array}$ & $\begin{array}{c}\text { Alka- } \\
\text { linity, } \\
\text { lab } \\
(\mathrm{mg} / \mathrm{L} \\
\text { as } \\
\left.\mathrm{CaCO}_{3}\right)\end{array}$ & $\begin{array}{c}\text { Nitro- } \\
\text { gen } \\
\text { ammo- } \\
\text { nia, } \\
\text { dis- } \\
\text { solved } \\
\text { (mg/L } \\
\text { as } \mathrm{N} \text { ) }\end{array}$ & $\begin{array}{c}\text { Nitro- } \\
\text { gen, } \\
\text { nitrite, } \\
\text { dis- } \\
\text { solved } \\
\text { (mg/L } \\
\text { as } \mathrm{N} \text { ) }\end{array}$ \\
\hline $03-286$ & $07-19-90$ & 1135 & 15.5 & 721 & 722 & 0.7 & 7.5 & 228 & 225 & 0.14 & $<0.01$ \\
\hline $03-287$ & $07-17-90$ & 1420 & 18.5 & 760 & 829 & 2.2 & 7.2 & 236 & 239 & $<.01$ & .03 \\
\hline $03-288$ & $01-15-91$ & 1520 & 13.0 & 529 & 547 & 6.8 & 7.8 & -- & 147 & .02 & $<.01$ \\
\hline $19-249$ & $12-13-89$ & 1630 & 12.0 & 630 & 640 & 1.7 & 7.1 & 114 & 105 & .02 & .07 \\
\hline $19-250$ & $02-13-90$ & 1650 & 12.5 & 615 & 575 & .6 & 7.5 & 180 & 168 & .06 & $<.01$ \\
\hline $19-251$ & $12-07-89$ & 1430 & 11.5 & 422 & 435 & 3.3 & 7.5 & 156 & 142 & .02 & .05 \\
\hline \multirow[t]{3}{*}{$21-289$} & $06-19-85$ & 1600 & 12.0 & 365 & 387 & 3.6 & 7.8 & 128 & -- & -- & -- \\
\hline & $06-25-87$ & 1350 & 12.0 & 373 & -- & 2.3 & 7.3 & 120 & -- & -- & -- \\
\hline & $08-18-88$ & 1425 & 12.5 & 403 & 387 & 2.3 & 7.6 & 115 & 127 & $<.01$ & $<.01$ \\
\hline $21-358$ & $01-11-90$ & 1425 & 12.0 & 700 & 981 & 3.8 & 6.4 & 76 & 69 & .01 & $<.01$ \\
\hline $23-801$ & $04-24-86$ & 1400 & 12.5 & 350 & 352 & .3 & 7.6 & 145 & -- & .05 & $<.01$ \\
\hline $23-1076$ & $05-23-86$ & 1535 & 13.5 & 748 & 707 & .2 & 7.2 & 217 & -- & -- & -- \\
\hline $23-1083$ & $05-07-87$ & 1215 & 12.5 & 645 & 676 & .1 & 7.0 & 213 & -- & .34 & $<.01$ \\
\hline
\end{tabular}

\begin{tabular}{|c|c|c|c|c|c|c|c|c|c|c|c|}
\hline $\begin{array}{c}\text { Well } \\
\text { number }\end{array}$ & $\begin{array}{c}\text { Date } \\
\text { of } \\
\text { sampling }\end{array}$ & $\begin{array}{c}\text { Nitro- } \\
\text { gen, am- } \\
\text { monia + } \\
\text { organic, } \\
\text { dissolved } \\
\text { (mg/L } \\
\text { as } N \text { ) }\end{array}$ & $\begin{array}{c}\text { Nitro- } \\
\text { gen, } \\
\mathrm{NO}_{2}+ \\
\mathrm{NO}_{3} \text {, } \\
\text { dis- } \\
\text { solved } \\
\text { (mg/L } \\
\text { as } \mathrm{N} \text { ) }\end{array}$ & $\begin{array}{l}\text { Phos- } \\
\text { phorus, } \\
\text { ortho, } \\
\text { dis- } \\
\text { solved } \\
\text { (mg/L } \\
\text { as P) }\end{array}$ & $\begin{array}{c}\text { Carbon, } \\
\text { organic, } \\
\text { dis- } \\
\text { solved } \\
\text { (mg/L } \\
\text { as C) }\end{array}$ & $\begin{array}{c}\text { Calcium. } \\
\text { dis- } \\
\text { solved } \\
(\mathrm{mg} / \mathrm{L} \\
\text { as } \mathrm{Ca})\end{array}$ & $\begin{array}{l}\text { Magne- } \\
\text { sium, } \\
\text { dis- } \\
\text { solved } \\
\text { (mg/L } \\
\text { as } \mathrm{Mg}) \\
\end{array}$ & $\begin{array}{c}\text { Sodium, } \\
\text { dis- } \\
\text { solved } \\
\text { (mg/L } \\
\text { as } \mathrm{Na} \text { ) }\end{array}$ & $\begin{array}{c}\text { Potas- } \\
\text { sium, } \\
\text { dis- } \\
\text { solved } \\
\text { (mg/L } \\
\text { as K) }\end{array}$ & $\begin{array}{l}\text { Chlo- } \\
\text { ride, } \\
\text { dis- } \\
\text { solved } \\
(\mathrm{mg} / \mathrm{L} \\
\text { as } \mathrm{Cl}) \\
\end{array}$ & $\begin{array}{c}\begin{array}{c}\text { Sulfate, } \\
\text { dis- } \\
\text { solved } \\
(\mathrm{mg} / \mathrm{L}\end{array} \\
\left.\text { as } \mathrm{SO}_{4}\right) \\
\end{array}$ \\
\hline $03-286$ & $07-19-90$ & 0.7 & 4.4 & 0.02 & 1.6 & 89 & 18 & 29 & 1.5 & 72 & 34 \\
\hline $03-287$ & $07-17-90$ & .5 & 4.6 & $<.01$ & .3 & 110 & 12 & 42 & 1.9 & 90 & 38 \\
\hline $03-288$ & $01-15-91$ & .7 & 11.0 & .04 & .7 & 79 & 12 & 13 & 1.0 & 37 & 38 \\
\hline $19-249$ & $12-13-89$ & .3 & 1.6 & $<.01$ & .6 & 52 & 25 & 26 & 8.6 & 110 & 41 \\
\hline $19-250$ & $02-13-90$ & $<.2$ & $<.1$ & $<.01$ & 1.9 & 68 & 16 & 23 & 10.0 & 37 & 71 \\
\hline $19-251$ & $12-07-89$ & $<.2$ & .86 & .01 & .6 & 59 & 9.3 & 18 & 2.8 & 14 & 51 \\
\hline \multirow[t]{3}{*}{$21-289$} & $06-19-85$ & -- & - & -- & -- & 44 & 16 & 11 & 1.2 & 13 & 17 \\
\hline & $06-25-87$ & -- & -- & -- & -- & -- & -- & -- & -- & -- & -- \\
\hline & $08-18-88$ & .2 & 6.4 & .04 & .6 & 46 & 16 & 11 & 1.2 & 14 & 22 \\
\hline $21-358$ & $01-11-90$ & $<.2$ & 4.1 & .04 & .9 & 56 & 23 & 87 & 2.8 & 230 & 28 \\
\hline $23-801$ & $04-24-86$ & .2 & $<.1$ & .02 & - & 45 & 12 & 9.7 & 1.7 & 11 & 15 \\
\hline 23-1076 & $05-23-86$ & -- & -- & -- & -- & 94 & 18 & 28 & 2.0 & 71 & 51 \\
\hline $23-1083$ & $05-07-87$ & .8 & $<.1$ & $<.01$ & 2.3 & 90 & 16 & 24 & 1.5 & 52 & 61 \\
\hline
\end{tabular}


Appendix C. Physical properties of, and concentrations of major ions, nutrients, trace elements, radioactive elements, and purgeable organic compounds in, water samples from boreholes or wells adjacent to boreholes, Newark Basin, New Jersey, 1985-1991--Continued

\begin{tabular}{|c|c|c|c|c|c|c|c|c|c|c|c|}
\hline $\begin{array}{c}\text { Well } \\
\text { number }\end{array}$ & $\begin{array}{c}\text { Date } \\
\text { of } \\
\text { sampling }\end{array}$ & $\begin{array}{l}\text { Fluo- } \\
\text { ride, } \\
\text { dis- } \\
\text { solved } \\
\text { (mg/L as } \\
\text { F) }\end{array}$ & $\begin{array}{c}\text { Silica, } \\
\text { dis- } \\
\text { solved } \\
(\mathrm{mg} / \mathrm{L} \text { as } \\
\left.\mathrm{SiO}_{2}\right)\end{array}$ & $\begin{array}{c}\text { Arsenic, } \\
\text { dis- } \\
\text { solved } \\
\text { ( } \mu \mathrm{g} / \mathrm{L} \text { as } \\
\text { As) }\end{array}$ & $\begin{array}{l}\text { Barium, } \\
\text { dis- } \\
\text { solved } \\
\text { ( } \mu \mathrm{g} / \mathrm{L} \text { as } \\
\mathrm{Ba})\end{array}$ & $\begin{array}{c}\text { Beryl- } \\
\text { lium, } \\
\text { dis- } \\
\text { solved } \\
(\mu \mathrm{g} / \mathrm{L} \text { as } \\
\mathrm{Be})\end{array}$ & $\begin{array}{l}\text { Cadmium, } \\
\text { dis- } \\
\text { solved } \\
(\mu \mathrm{g} / \mathrm{L} \text { as } \\
\text { Cd) }\end{array}$ & $\begin{array}{l}\text { Chro- } \\
\text { mium, } \\
\text { dis- } \\
\text { solved } \\
(\mu \mathrm{g} / \mathrm{L} \text { as } \\
\text { Cr })\end{array}$ & $\begin{array}{c}\text { Cobalt, } \\
\text { dis- } \\
\text { solved } \\
(\mu \mathrm{g} / \mathrm{L} \text { as } \\
\mathrm{Co})\end{array}$ & $\begin{array}{c}\text { Copper, } \\
\text { dis- } \\
\text { solved } \\
(\mu \mathrm{g} / \mathrm{L} \text { as } \\
\mathrm{Cu})\end{array}$ & $\begin{array}{c}\text { Iron, } \\
\text { dis- } \\
\text { solved } \\
(\mu \mathrm{g} / \mathrm{L} \text { as } \\
\mathrm{Fe})\end{array}$ \\
\hline $03-286$ & $07-19-90$ & 0.2 & 21 & 2 & 230 & $<0.5$ & $<1$ & $<5$ & $<3$ & $<10$ & 63 \\
\hline $03-287$ & $07-17-90$ & .2 & 22 & $<1$ & 160 & $<.5$ & 2 & $<5$ & $<3$ & $<10$ & 190 \\
\hline $03-288$ & $01-15-91$ & $<.1$ & 21 & $<1$ & 140 & $<.5$ & $<1$ & $<5$ & $<3$ & $<10$ & 7 \\
\hline $19-249$ & $12-13-89$ & .3 & 42 & $<1$ & 13 & $<.5$ & $<1$ & $<5$ & $<3$ & $<10$ & 9 \\
\hline $19-250$ & $02-13-90$ & .6 & 32 & 13 & 19 & $<.5$ & 2 & $<5$ & $<3$ & $<10$ & 110 \\
\hline $19-251$ & $12-07-89$ & .2 & 24 & 4 & 80 & $<.5$ & $<1$ & $<5$ & $<3$ & $<10$ & 17 \\
\hline \multirow[t]{3}{*}{$21-289$} & $06-19-85$ & .. & 24 & -- & 120 & $<.5$ & $<1$ & -- & $<3$ & $<10$ & 3 \\
\hline & $06-25-87$ & -- & -. & -- & -- & -- & -- & -- & -- & -- & -- \\
\hline & $08-18-88$ & .2 & 24 & 2 & 120 & $<.5$ & $<1$ & $<5$ & $<3$ & $<10$ & 4 \\
\hline $21-358$ & $01-11-90$ & $<.1$ & 18 & $<1$ & 290 & $<.5$ & $<1$ & $<5$ & $<3$ & $<10$ & 39 \\
\hline $23-801$ & $04-24-86$ & .1 & 27 & -- & 390 & $<.5$ & $<1$ & -- & $<3$ & $<10$ & 370 \\
\hline $23-1076$ & $05-23-86$ & -- & 28 & -- & 1,100 & $<.5$ & $<1$ & -- & $<3$ & $<10$ & 1,300 \\
\hline $23-1083$ & $05-07-87$ & -- & 32 & -- & 1,100 & $<.5$ & $<1$ & -- & $<3$ & $<10$ & 3,300 \\
\hline
\end{tabular}

\begin{tabular}{|c|c|c|c|c|c|c|c|c|c|c|c|}
\hline $\begin{array}{c}\text { Well } \\
\text { number }\end{array}$ & $\begin{array}{c}\text { Date } \\
\text { of } \\
\text { sampling }\end{array}$ & $\begin{array}{c}\text { Lead, } \\
\text { dis- } \\
\text { solved } \\
(\mu \mathrm{g} / \mathrm{L} \text { as } \\
\mathrm{Pb})\end{array}$ & $\begin{array}{c}\text { Manga- } \\
\text { nese, } \\
\text { dis- } \\
\text { solved } \\
(\mu \mathrm{g} / \mathrm{L} \text { as } \\
\mathrm{Mn}) \\
\end{array}$ & $\begin{array}{c}\text { Molyb- } \\
\text { denum, } \\
\text { dis- } \\
\text { solved } \\
\text { ( } \mu \text { g/L as } \\
\text { Mo) }\end{array}$ & $\begin{array}{l}\text { Nickel, } \\
\text { dis- } \\
\text { solved } \\
(\mu \mathrm{g} / \mathrm{L} \text { as } \\
\mathrm{Ni})\end{array}$ & $\begin{array}{l}\text { Silver, } \\
\text { dis- } \\
\text { solved } \\
(\mu \mathrm{g} / \mathrm{L} \text { as } \\
\mathrm{Ag})\end{array}$ & $\begin{array}{l}\text { Stron- } \\
\text { tium, } \\
\text { dis- } \\
\text { solved } \\
(\mu \mathrm{g} / \mathrm{L} \text { as } \\
\mathrm{Sr})\end{array}$ & $\begin{array}{l}\text { Vana- } \\
\text { dium, } \\
\text { dis- } \\
\text { solved } \\
(\mu \mathrm{g} / \mathrm{L} \text { as } \\
\mathrm{V})\end{array}$ & $\begin{array}{c}\text { Zinc, } \\
\text { dis- } \\
\text { solved } \\
(\mu \mathrm{g} / \mathrm{L} \text { as } \\
\mathrm{Zn})\end{array}$ & $\begin{array}{l}\text { Alum- } \\
\text { inum, } \\
\text { dis- } \\
\text { solved } \\
(\mu \mathrm{g} / \mathrm{L} \text { as } \\
\mathrm{Al})\end{array}$ & $\begin{array}{l}\text { Lithium, } \\
\text { dis- } \\
\text { solved } \\
\text { ( } \mu \mathrm{g} / \mathrm{L} \text { as } \\
\mathrm{Li})\end{array}$ \\
\hline $03-286$ & $07-19-90$ & $<10$ & 13 & $<10$ & $<10$ & $<1$ & 240 & $<6$ & 3 & $<10$ & 14 \\
\hline $03-287$ & $07-17-90$ & $<10$ & 16 & $<10$ & $<10$ & $<1$ & 140 & $<6$ & 5 & $<10$ & 13 \\
\hline $03-288$ & $01-15-91$ & $<10$ & $<1$ & $<10$ & $<10$ & $<1$ & 130 & $<6$ & 5 & 10 & 8 \\
\hline $19-249$ & $12-13-89$ & 10 & 220 & $<10$ & $<10$ & $<1$ & 220 & $<6$ & 5 & 10 & 86 \\
\hline $19-250$ & $02-13-90$ & $<10$ & 210 & 20 & 20 & $<1$ & 210 & $<6$ & $<3$ & $<10$ & 43 \\
\hline $19-251$ & $12-07-89$ & 10 & 260 & $<10$ & $<10$ & $<1$ & 430 & $<6$ & $<3$ & $<10$ & 19 \\
\hline \multirow[t]{3}{*}{$21-289$} & $06-19-85$ & $<10$ & 10 & $<10$ & -- & -- & 340 & $<6$ & 37 & -- & 19 \\
\hline & $06-25-87$ & -- & -- & -- & -- & -- & -- & -. & -- & -. & -- \\
\hline & $08-18-88$ & $<10$ & 18 & $<10$ & $<10$ & $<1$ & 340 & $<6$ & $<3$ & $<10$ & 19 \\
\hline $21-358$ & $01-11-90$ & $<10$ & 27 & $<10$ & $<10$ & $<1$ & 350 & $<6$ & $<3$ & 30 & 4 \\
\hline 23-801 & $04-24-86$ & $<10$ & 290 & $<10$ & - & -- & 410 & $<6$ & $<3$ & -. & 7 \\
\hline 23-1076 & $05-23-86$ & $<10$ & 660 & $<10$ & -- & -- & 590 & $<6$ & 9 & 20 & 33 \\
\hline $23-1083$ & $05-07-87$ & $<10$ & 640 & $<10$ & -- & -- & 560 & $<6$ & 5 & -- & 33 \\
\hline
\end{tabular}


Appendix C. Physical properties of, and concentrations of major ions, nutrients, trace elements, radioactive elements, and purgeable organic compounds in, water samples from boreholes or wells adjacent to boreholes, Newark Basin, New Jersey, 1985-1991--Continued

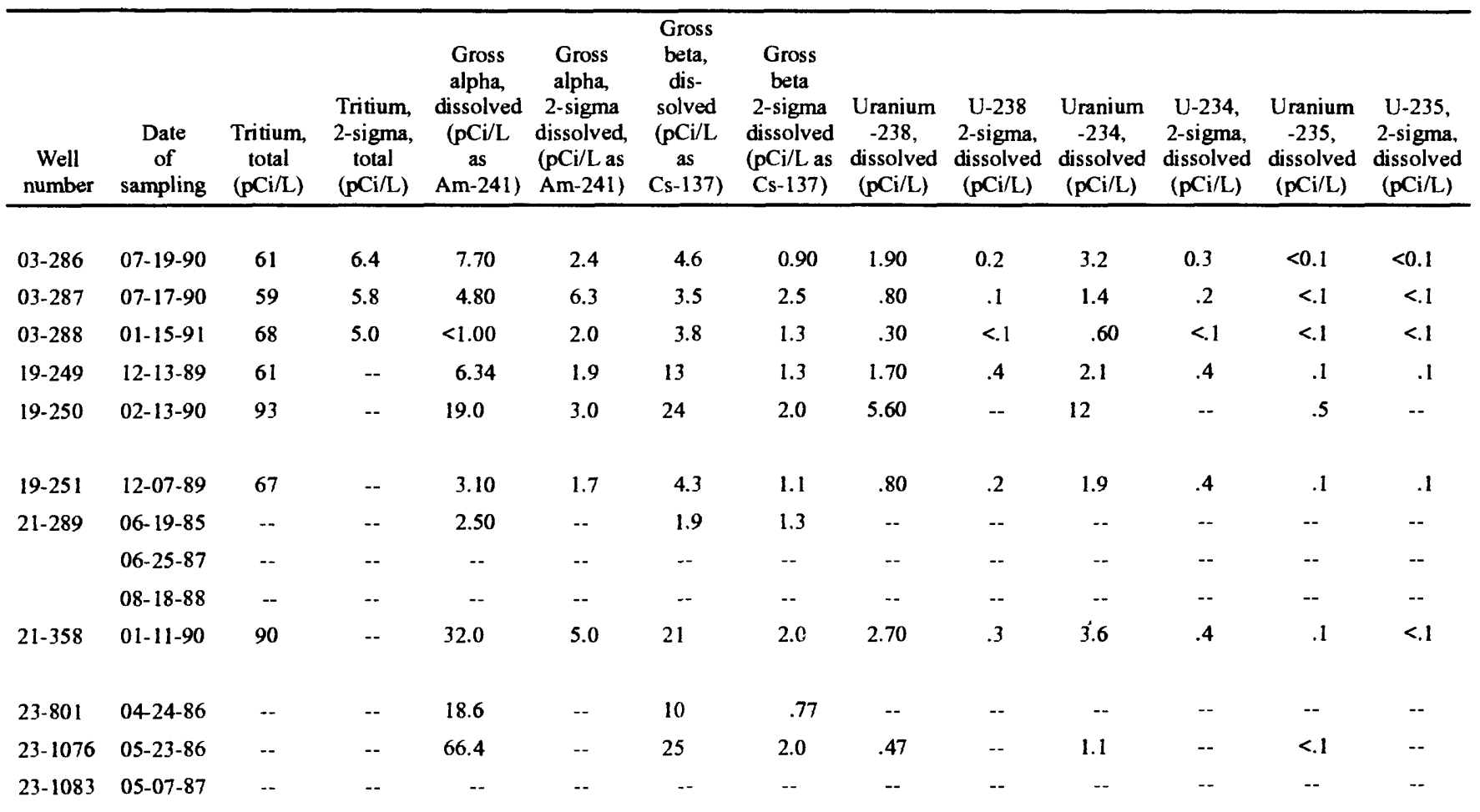

\begin{tabular}{|c|c|c|c|c|c|c|c|c|c|c|c|c|c|c|}
\hline $\begin{array}{c}\text { Well } \\
\text { number }\end{array}$ & $\begin{array}{c}\text { Date } \\
\text { of } \\
\text { sampling }\end{array}$ & $\begin{array}{c}\text { Uranium, } \\
\text { natural, } \\
\text { dis- } \\
\text { solved } \\
(\mu \mathrm{g} / \mathrm{L} \\
\text { as } \mathrm{U})\end{array}$ & $\begin{array}{c}\text { Ra-226, } \\
\text { dis- } \\
\text { solved, } \\
\text { plan- } \\
\text { chet } \\
\text { count } \\
\text { (pCi/L) }\end{array}$ & $\begin{array}{c}\mathrm{Ra}-226 \\
\text { 2-sigma } \\
\text { dissolved } \\
(\mathrm{pCi} / \mathrm{L})\end{array}$ & $\begin{array}{c}\text { Radium } \\
-228, \\
\text { dis- } \\
\text { solved } \\
(\mathrm{pCi} / \mathrm{L} \text { as } \\
\mathrm{Ra}-228) \\
\end{array}$ & $\begin{array}{c}\mathrm{Ra}-228 \\
\text { 2-sigma } \\
\text { dissolved } \\
(\mathrm{pCi} / \mathrm{L})\end{array}$ & $\begin{array}{c}\text { Radon } \\
-222, \\
\text { total } \\
(\mathrm{pCi} / \mathrm{L})\end{array}$ & $\begin{array}{c}\text { Rn-222 } \\
\text { 2-sigma } \\
\text { water, } \\
\text { whole, } \\
\text { total, } \\
\text { (pCi } / \mathrm{L})\end{array}$ & $\begin{array}{c}\text { Di- } \\
\text { chloro- } \\
\text { bromo- } \\
\text { methane, } \\
\text { total } \\
(\mu \mathrm{g} / \mathrm{L})\end{array}$ & $\begin{array}{l}\text { Carbon } \\
\text { tetra- } \\
\text { chlo- } \\
\text { ride, } \\
\text { total } \\
(\mu \mathrm{g} / \mathrm{L})\end{array}$ & $\begin{array}{c}\text { 1,2-Di- } \\
\text { chloro- } \\
\text { ethane, } \\
\text { total } \\
(\mu \mathrm{g} / \mathrm{L})\end{array}$ & $\begin{array}{c}\text { Bromo- } \\
\text { form, } \\
\text { total } \\
(\mu \mathrm{g} / \mathrm{L})\end{array}$ & $\begin{array}{c}\text { Chloro- } \\
\text { di- } \\
\text { bromo- } \\
\text { methane, } \\
\text { total } \\
(\mu \mathrm{g} / \mathrm{L}) \\
\end{array}$ & $\begin{array}{c}\text { Chloro- } \\
\text { form, } \\
\text { total } \\
(\mu \mathrm{g} / \mathrm{L})\end{array}$ \\
\hline $03-286$ & $07-19-90$ & -- & 0.21 & 0.15 & $<0.60$ & -- & 2,060 & 90 & $<0.2$ & $<0.2$ & $<0.2$ & $<0.2$ & $<0.2$ & 0.4 \\
\hline $03-287$ & $07-17-90$ & -- & $<.20$ & .14 & $<.60$ & -- & 1,470 & 40 & $<.2$ & $<.2$ & $<.2$ & $<.2$ & $<.2$ & 2.7 \\
\hline $03-288$ & $01-15-91$ & -. & $<.30$ & .20 & $<.80$ & -- & 1,300 & 100 & -- & -. & -- & -- & -- & -- \\
\hline $19-249$ & $12-13-89$ & -- & $<.25$ & .18 & $<1.00$ & -. & 1,400 & 100 & -- & - & -- & -- & -- & -- \\
\hline $19-250$ & $02-13-90$ & - & 2.40 & .40 & $<.70$ & -- & 22,000 & 1,000 & -- & -. & -- & -- & -- & -- \\
\hline $19-251$ & $12-07-89$ & -- & .30 & .18 & $<1.00$ & -. & 1.730 & 20 & -- & - & -- & -- & - & -- \\
\hline \multirow[t]{3}{*}{$21-289$} & $06-19-85$ & 1.50 & $<.6$ & .14 & - & - & -- & -- & -- & -- & -- & -- & -- & -- \\
\hline & $06-25-87$ & -- & -. & -- & .. & -- & 1,370 & 60 & -- & -- & -- & -- & -- & -- \\
\hline & $08-18-88$ & -- & -. & -- & -- & -- & -- & - & $<.2$ & $<.2$ & $<.2$ & $<.2$ & $<.2$ & $<.2$ \\
\hline $21-358$ & $01-11-90$ & -. & 3.20 & .40 & $<.67$ & -- & 32.100 & 500 & $<.2$ & $<.2$ & $<.2$ & $<.2$ & $<.2$ & .3 \\
\hline
\end{tabular}


Appendix C. Physical properties of, and concentrations of major ions, nutrients, trace elements, radioactive elements, and purgeable organic compounds in, water samples from boreholes or wells adjacent to boreholes, Newark Basin, New Jersey, 1985-1991--Continued

\begin{tabular}{|c|c|c|c|c|c|c|c|c|c|c|c|}
\hline $\begin{array}{c}\text { Well } \\
\text { number }\end{array}$ & $\begin{array}{c}\text { Date } \\
\text { of } \\
\text { sampling }\end{array}$ & $\begin{array}{c}\text { Toluene, } \\
\text { total } \\
(\mu \mathrm{g} / \mathrm{L})\end{array}$ & $\begin{array}{c}\text { Benzene, } \\
\text { total } \\
(\mu \mathrm{g} / \mathrm{L})\end{array}$ & $\begin{array}{c}\text { Chloro- } \\
\text { benzene, } \\
\text { total } \\
(\mu \mathrm{g} / \mathrm{L})\end{array}$ & $\begin{array}{l}\text { Chloro- } \\
\text { ethane, } \\
\text { total } \\
(\mu \mathrm{g} / \mathrm{L})\end{array}$ & $\begin{array}{c}\text { Ethyl- } \\
\text { benzene, } \\
\text { total } \\
(\mu \mathrm{g} / \mathrm{L})\end{array}$ & $\begin{array}{c}\text { Methyl- } \\
\text { bromide, } \\
\text { total } \\
(\mu \mathrm{g} / \mathrm{L})\end{array}$ & $\begin{array}{l}\text { Methyl- } \\
\text { chlo- } \\
\text { ride, } \\
\text { total } \\
(\mu \mathrm{g} / \mathrm{L})\end{array}$ & $\begin{array}{l}\text { Methyl- } \\
\text { ene } \\
\text { chlo- } \\
\text { ride, } \\
\text { total } \\
(\mu \mathrm{g} / \mathrm{L})\end{array}$ & $\begin{array}{l}\text { Tetra- } \\
\text { chloro- } \\
\text { ethyl- } \\
\text { ene, } \\
\text { total } \\
(\mu \mathrm{g} / \mathrm{L})\end{array}$ & $\begin{array}{c}\text { Tri- } \\
\text { chloro- } \\
\text { fluoro- } \\
\text { methane. } \\
\text { total } \\
(\mu \mathrm{g} / \mathrm{L})\end{array}$ \\
\hline $03-286$ & $07-19-90$ & $<0.2$ & $<0.2$ & $<0.2$ & $<0.2$ & $<0.2$ & $<0.2$ & $<0.2$ & $<0.2$ & 0.6 & $<0.2$ \\
\hline $03-287$ & $07-17-90$ & $<.2$ & $<.2$ & $<.2$ & $<.2$ & $<.2$ & $<.2$ & $<.2$ & $<.2$ & 1.9 & $<.2$ \\
\hline $03-288$ & $01-15-91$ & -- & - & -. & - & -- & -- & -- & -. & -- & -- \\
\hline $19-249$ & $12-13-89$ & -- & -- & -- & -- & -- & -- & -- & -. & -- & -- \\
\hline $19-250$ & $02-13-90$ & -- & -. & - & -. & -- & -- & -- & - & - & -- \\
\hline $19-251$ & $12-07-89$ & -- & -- & -- & -- & -- & -- & - & - & -- & -- \\
\hline \multirow[t]{3}{*}{$21-289$} & $06-19-85$ & -- & -- & -- & -- & -- & -- & -- & - & -. & -. \\
\hline & $06-25-87$ & -- & -- & -- & -- & -- & -- & -- & -. & -- & -- \\
\hline & $08-18-80$ & $<.2$ & $<.2$ & $<.2$ & $<.2$ & $<.2$ & $<.2$ & $<.2$ & $<.2$ & $<.2$ & $<.2$ \\
\hline $21-358$ & $01-11-90$ & $<.2$ & $<.2$ & $<.2$ & $<.2$ & $<.2$ & $<.2$ & $<.2$ & $<.2$ & $<.2$ & $<.2$ \\
\hline $23-801$ & $04-24-86$ & -- & -- & -- & -- & -- & - & - & -- & -- & -. \\
\hline $23-1076$ & $05-23-86$ & -. & -- & -- & - & -- & - & $-\cdot$ & -- & -- & -- \\
\hline $23-1083$ & $05-07-87$ & -- & -- & -- & -- & -- & -- & -- & - & - & -- \\
\hline
\end{tabular}

\begin{tabular}{|c|c|c|c|c|c|c|c|c|c|c|c|}
\hline $\begin{array}{c}\text { Well } \\
\text { number }\end{array}$ & $\begin{array}{c}\text { Date } \\
\text { of } \\
\text { sampling }\end{array}$ & $\begin{array}{l}1,1-\mathrm{Di}- \\
\text { chloro- } \\
\text { ethane, } \\
\text { total } \\
(\mu \mathrm{g} / \mathrm{L})\end{array}$ & $\begin{array}{l}\text { 1,1-Di- } \\
\text { chloro- } \\
\text { ethyl- } \\
\text { ene, } \\
\text { total } \\
(\mu \mathrm{g} / \mathrm{L})\end{array}$ & $\begin{array}{l}1,1,1- \\
\text { Tri- } \\
\text { chloro- } \\
\text { ethane, } \\
\text { total } \\
(\mu \mathrm{g} / \mathrm{L})\end{array}$ & $\begin{array}{c}1,1,2- \\
\text { Tri- } \\
\text { chloro- } \\
\text { ethane, } \\
\text { total } \\
(\mu \mathrm{g} / \mathrm{L})\end{array}$ & $\begin{array}{l}\text { 1,1,2,2- } \\
\text { Tetra- } \\
\text { chloro- } \\
\text { ethane, } \\
\text { total } \\
(\mu \mathrm{g} / \mathrm{L})\end{array}$ & $\begin{array}{c}\text { 1,2-Di- } \\
\text { chloro- } \\
\text { benzene, } \\
\text { total } \\
(\mu \mathrm{g} / \mathrm{L})\end{array}$ & $\begin{array}{c}\text { 1,2-Di- } \\
\text { chloro- } \\
\text { propane, } \\
\text { total } \\
(\mu \mathrm{g} / \mathrm{L})\end{array}$ & $\begin{array}{c}1,2- \\
\text { transDi- } \\
\text { chloro- } \\
\text { ethene, } \\
\text { total } \\
(\mu \mathrm{g} / \mathrm{L})\end{array}$ & $\begin{array}{c}\text { 1.3-Di- } \\
\text { chloro- } \\
\text { propene, } \\
\text { total } \\
(\mu \mathrm{g} / \mathrm{L})\end{array}$ & $\begin{array}{c}\text { 1,3-Di- } \\
\text { chloro- } \\
\text { benzene, } \\
\text { total } \\
(\mu \mathrm{g} / \mathrm{L})\end{array}$ \\
\hline $03-286$ & $07-19-90$ & 0.4 & $<0.2$ & 0.4 & $<0.2$ & $<0.2$ & $<0.2$ & 16.0 & 0.3 & $<0.2$ & $<0.2$ \\
\hline $03-287$ & $07-17-90$ & .2 & $<.2$ & .6 & $<.2$ & $<.2$ & $<.2$ & 1.3 & .3 & $<.2$ & $<.2$ \\
\hline $03-288$ & $01-15-91$ & - & -- & -- & -- & -. & - & -- & -- & -- & -- \\
\hline $19-249$ & $12-13-89$ & -. & -- & -- & -- & -- & -- & -- & -- & -- & -- \\
\hline $19-250$ & $02-13-90$ & -. & - & -- & -- & -- & -- & -- & -- & - & -- \\
\hline $19-251$ & $12-07-89$ & -- & -- & - & -- & -- & -- & -- & -- & -- & - \\
\hline \multirow[t]{3}{*}{$21-289$} & $06-19-85$ & -- & -- & -- & -- & -- & -- & -- & -- & -- & -- \\
\hline & $06-25-87$ & -- & -- & -- & -- & -- & -- & -- & -. & -- & -- \\
\hline & $08-18-80$ & $<.2$ & $<.2$ & $<.2$ & $<.2$ & $<.2$ & $<.2$ & $<.2$ & $<.2$ & $<.2$ & $<.2$ \\
\hline $21-358$ & $01-11-90$ & $<.2$ & .9 & 51.0 & $<.2$ & $<.2$ & $<.2$ & $<.2$ & $<.2$ & $<.2$ & $<.2$ \\
\hline $23-801$ & $04-24-86$ & -- & -- & -- & -- & -- & -- & -- & -- & -- & - \\
\hline $23-1076$ & $05-23-86$ & -- & - & -- & -- & -- & - & -- & -- & -- & -- \\
\hline $23-1083$ & $05-07-87$ & -- & -- & -- & -- & -- & -- & -- & -- & -- & -. \\
\hline
\end{tabular}


Appendix C. Physical properties of, and concentrations of major ions, nutrients, trace elements, radioactive elements, and purgeable organic compounds in, water samples from boreholes or wells adjacent to boreholes, Newark Basin, New Jersey, 1985-1991--Continued

\begin{tabular}{|c|c|c|c|c|c|c|c|c|c|c|c|}
\hline $\begin{array}{c}\text { Well } \\
\text { number }\end{array}$ & $\begin{array}{c}\text { Date } \\
\text { of } \\
\text { sampling }\end{array}$ & $\begin{array}{c}\text { 1,4-Di- } \\
\text { chloro- } \\
\text { benzene, } \\
\text { total } \\
(\mu \mathrm{g} / \mathrm{L})\end{array}$ & $\begin{array}{c}2- \\
\text { Chloro- } \\
\text { ethyl- } \\
\text { vinyl- } \\
\text { ether. } \\
\text { total } \\
(\mu \mathrm{g} / \mathrm{L})\end{array}$ & $\begin{array}{c}\text { Di- } \\
\text { chloro- } \\
\text { di- } \\
\text { fluoro- } \\
\text { methane. } \\
\text { total } \\
(\mu \mathrm{g} / \mathrm{L})\end{array}$ & $\begin{array}{c}\text { trans- } \\
1,3-\mathrm{Di}- \\
\text { chloro- } \\
\text { propene. } \\
\text { total } \\
(\mu \mathrm{g} / \mathrm{L})\end{array}$ & $\begin{array}{c}\text { cis } \\
1,3-\mathrm{Di}- \\
\text { chloro- } \\
\text { propene, } \\
\text { total } \\
(\mu \mathrm{g} / \mathrm{L})\end{array}$ & $\begin{array}{l}\text { Vinyl } \\
\text { chlor- } \\
\text { ride. } \\
\text { total } \\
(\mu \mathrm{g} / \mathrm{L})\end{array}$ & $\begin{array}{c}\text { Tri- } \\
\text { chloro- } \\
\text { ethyl- } \\
\text { ene. } \\
\text { total } \\
(\mu \mathrm{g} / \mathrm{L})\end{array}$ & $\begin{array}{c}\text { Styrene, } \\
\text { total } \\
(\mu \mathrm{g} / \mathrm{L})\end{array}$ & $\begin{array}{c}1,2- \\
\text { Dibromo- } \\
\text { ethane. } \\
\text { total } \\
(\mu \mathrm{g} / \mathrm{L})\end{array}$ & $\begin{array}{c}\text { Xylene, } \\
\text { whole } \\
\text { total } \\
\text { recover- } \\
\text { able } \\
(\mu \mathrm{g} / \mathrm{L})\end{array}$ \\
\hline $03-286$ & $07-19-90$ & $<0.2$ & $<0.2$ & $<0.2$ & $<0.2$ & $<0.2$ & $<0.2$ & 8.3 & $<0.2$ & $<0.2$ & $<0.2$ \\
\hline $03-287$ & $07-17-90$ & $<.2$ & $<.2$ & $<.2$ & $<.2$ & $<.2$ & $<.2$ & 3.9 & $<.2$ & $<.2$ & $<.2$ \\
\hline $03-288$ & $01-15-91$ & -- & -. & -. & -- & -- & -- & -- & -- & -- & -- \\
\hline $19-249$ & $12-13-89$ & -- & -- & -- & -- & -- & -. & -. & -- & -- & -- \\
\hline $19-250$ & $02-13-90$ & -- & -- & -- & -- & -- & -- & -- & -- & -- & -- \\
\hline $19-251$ & $12-07-89$ & -- & -- & -- & -- & -- & -- & -- & -- & -- & -- \\
\hline \multirow[t]{3}{*}{$21-289$} & $06-19-85$ & -- & -- & -- & -- & -. & -- & -- & -- & -- & -- \\
\hline & $06-25-87$ & - & -- & -- & -. & -. & -- & -- & -- & -- & -- \\
\hline & $08-18-88$ & $<.2$ & $<.2$ & $<.2$ & $<.2$ & $<.2$ & $<.2$ & $<.2$ & $<.2$ & -- & $<.2$ \\
\hline $21-358$ & $01-11-90$ & $<.2$ & $<.2$ & $<.2$ & $<.2$ & $<.2$ & $<.2$ & $<, 2$ & $<.2$ & $<.2$ & $<.2$ \\
\hline $23-801$ & $04-24-86$ & -. & -. & -- & - & -- & -- & -- & -- & -- & -- \\
\hline $23-1076$ & $05-23-86$ & -. & -- & -- & -- & -- & -- & -- & -- & -- & -- \\
\hline $23-1083$ & $05-07-87$ & -- & -. & -- & -. & -- & -. & -- & -- & -- & -- \\
\hline
\end{tabular}

\begin{tabular}{|c|c|c|c|c|}
\hline $\begin{array}{c}\text { Well } \\
\text { number }\end{array}$ & $\begin{array}{c}\text { Date } \\
\text { of } \\
\text { sample }\end{array}$ & $\begin{array}{c}\text { H-2/ } \\
\text { H-1 } \\
\text { stable } \\
\text { isotope } \\
\text { ratio } \\
\text { (per } \\
\text { thousand) }\end{array}$ & $\begin{array}{c}\text { O-18/ } \\
\text { O-16 } \\
\text { stable } \\
\text { isotope } \\
\text { ratio } \\
\text { (per } \\
\text { thousand) }\end{array}$ & $\begin{array}{c}\text { S-34/ } \\
\text { S-32 } \\
\text { stable } \\
\text { isotope } \\
\text { ratio } \\
\text { (per } \\
\text { thousand) }\end{array}$ \\
\hline $03-286$ & $07-19-90$ & -43.5 & -7.35 & 3.9 \\
\hline $03-287$ & $07-17-90$ & -44.5 & -7.40 & 5.3 \\
\hline $03-288$ & $01-15-91$ & -44.5 & -7.50 & 4.9 \\
\hline $19-249$ & $12-13-89$ & -45.5 & -7.20 & 4.4 \\
\hline $19-250$ & $02-13-90$ & -43.4 & -7.20 & 6.2 \\
\hline $19-251$ & $12-07-89$ & -41.0 & -7.10 & 3.8 \\
\hline \multirow[t]{3}{*}{$21-289$} & $06-19-85$ & -- & -- & -- \\
\hline & $06-25-87$ & -- & -- & -- \\
\hline & $08-18-88$ & -- & -- & -- \\
\hline $21-358$ & $01-11-90$ & -44.0 & -7.25 & 2.1 \\
\hline $23-801$ & $04-24-86$ & -- & -- & -- \\
\hline $23-1076$ & $05-23-86$ & -- & -- & -- \\
\hline $23-1083$ & $05-07-87$ & -- & -- & -- \\
\hline
\end{tabular}


Appendix D. Description of lithology, fracture characteristics, and ground-water quality at selected sites, Newark Basin, New Jersey

\section{Site 1}

Lithologic descriptions of cores and gamma logs collected from borehole 23-932, which was completed in the Stockton Formation, are given on plate 1. Rocks at site 1 are predominantly pale orange (10YR8/2) and pinkish-gray (5YR8/1) to yellowish-gray (5Y8/1), very fine- to finegrained sandstones. Below a depth of $95 \mathrm{ft}$, however, the sandstone is very light gray (N8) and fine- to medium-grained. Pale red (5R6/2) siltstones comprise only about 36 percent of the described core, but are present predominantly in the upper half; the lower half is dominated by the fine- to medium-grained sandstones.

Bedding in the sandstones is predominantly massive, but laminar to cross-bedded strata are found in places. The siltstones are dominated by massive bedding; however, some convoluted bedding is present. At depths of 84 to $94 \mathrm{ft}$, birds-eye mottling is present. Birds-eye mottling, reported in the Lockatong Formation by Van Houten (1980), is attributed to a series of small shrinkage cracks in mudstone filled with calcite or dolomite. At the base of the siltstone section at a depth of 58 to $60 \mathrm{ft}$ is a thin zone of semiconsolidated clay. Evidence of calcite-filled root casts and worm burrows is common in the siltstone at a depth of 26 to $60 \mathrm{ft}$. Styolites are abundant throughout the core but are most common in the yellowish gray fine-grained sandstone from about 69 to $85 \mathrm{ft}$.

Secondary minerals derived from diagenetic and weathering reactions are common throughout the core. Pyrite speckling is common in the sandstones and local post-depositional void-filling calcite speckling is common in the siltstones. Minor amounts of iron-oxide speckling are present in the uppermost weathered siltstone and at a depth of about $60 \mathrm{ft}$ near the base of the thick massive pale red siltstone; the sandstones above this depth are also stained with limonite. Clay cements and clay fracture fillings are common in the massive sandstones below a depth of $60 \mathrm{ft}$.

Nine rock samples were collected from borehole 23-932 from site 1 for radioactivity analysis (pl. 1; app. B-2). In conjunction with analysis for radioactivity, the chemical composition of four of the nine samples was determined $(9.5,102.5,102.6$, and $110.6 \mathrm{ft})$. The major-, minor-, and trace-element concentrations are listed in appendix B-1. Iron constituted 2.6 percent of the shallowest sample (from a depth of $9.5 \mathrm{ft}$ ) and 2.27 percent of the sample from a depth of $110.6 \mathrm{ft}$. These percentages are higher than those determined for the other two samples, which were obtained from depths of 102.5 and $102.6 \mathrm{ft}$. The concentration of aluminum in the sample from $102.6 \mathrm{ft}$ was more than twice the concentration in the other three samples, likely because this sample was cemented by a chalky white clay mineral. Inorganic carbon in samples from site 1 ranged from less than 0.01 to 0.24 percent, whereas organic carbon ranged from 0.02 percent in the deepest sample to 0.18 percent in the sample from a depth of $102.5 \mathrm{ft}$. Silica ranged from 63 to 83 percent of the four samples. The percentage of silica in whole-rock samples from site 1 was greater 
than that for samples from sites 3 and 5, but was within the range of silica percentages for Mesozoic arkosic sandstones reported by Pettijohn (1963). The maximum concentration of the trace element barium was $632 \mu \mathrm{g} / \mathrm{g}$, in the sample from a depth of $102.5 \mathrm{ft}$.

The radioactivity of the nine rock samples was determined in the laboratory by gammaspectrometric methods. Four of the samples contained uranium (app. B-2) in concentrations that probably exceed typical background levels. Rock samples 1-5 to 1-7, collected at depths of 102 to $102.6 \mathrm{ft}$, contained slightly higher concentrations of uranium than those in most of the other samples from this borehole. Uranium concentrations in these three samples were higher than concentrations of thorium, indicating the probability of slight uranium enrichment in this stratigraphic interval. An anomalous peak of radioactivity was found on the gamma log between 104 and $106 \mathrm{ft} \mathrm{(pl.} \mathrm{1);} \mathrm{this} \mathrm{peak} \mathrm{coincides} \mathrm{with} \mathrm{a} \mathrm{massive} \mathrm{sandstone} \mathrm{with} \mathrm{few} \mathrm{styolites} \mathrm{and} \mathrm{local} \mathrm{pyrite}$ speckling. The sample from a depth of $40.1 \mathrm{ft}$ was most enriched in uranium; it contained $23 \mathrm{ppm}$ of uranium (app. B-2), whereas the thorium concentration in this sample was less than $5 \mathrm{ppm}$. The sample from a depth of $9.5 \mathrm{ft}$ was enriched in thorium relative to the other samples from the core, but not in uranium; the apparent thorium enrichment may be caused by intensive weathering at this shallow depth resulting in soluble uranium being leached from the rock. The percentage of potassium was greatest (7.6) in the sample from a depth of $25 \mathrm{ft}$. Elevated gross gamma counts for the rock samples from depths of 9.5 and $40.1 \mathrm{ft}$ (app. B-2) correlate with minor peaks on the gamma $\log$ of the borehole (pl. 1).

The caliper log, spontaneous-potential log, single-point-resistance log and gamma log, fracture-density histogram, and fracture-surface mineralogy for borehole 23-932 are shown on plate 2 . The shallowest highly fractured interval ( $>10$ fractures per 5 -ft interval) is adjacent to the regolith and comprises the transition zone, and consists of a weathered siltstone and fine-grained sandstone. Harned (1989) reports that the most highly fractured zones in the North Carolina Piedmont are in the transition zone (fig. 6) immediately below the regolith (which provides the bulk of the ground-water storage). The transition zone at this site (about 10 to $17 \mathrm{ft}$ below land surface) is apparent on the spontaneous-potential $\log$ as the greatest interval of positive signal intensity and is also apparent in the fracture-density $\log$ (which begins at a depth of $10 \mathrm{ft})(\mathrm{pl} .2)$. The interval from 10 to $15 \mathrm{ft}$, in addition to the numerous high- and low-angle fractures, contains a single 3-in.-thick fissured zone. A moderately fractured interval ( 55 to $60 \mathrm{ft}$ ) consists of a massive siltstone laced with many styolites and a zone of semiconsolidated clay. The styolites appear to coincide with the fracturing, and fluid movement along the styolites is evident from their limonite-stained nature. The moderately fractured interval at $75 \mathrm{ft}$ is a yellowish-gray, fine-grained sandstone containing many styolites and some pyrite speckling. A slightly fractured interval from 100 to $105 \mathrm{ft}$ is a lightgray sandstone with few styolites and local pyrite speckling. The interval from 100 to $105 \mathrm{ft}$ also contains a 3-in.-thick fissured zone in a stratum that is slightly enriched in uranium, indicating that any water that might be circulating through the fissured zone is in contact with uraniferous rocks. Low-angle open fractures dominate the fracture zones, although in the 10-to-50-ft section, about 22 percent of the fractures are of the high-angle open variety. 
The significant sustainable well yields at site 1 and in the surrounding area (Lewis and Spitz, 1987) indicate that the aquifer has a well-connected fracture system, allowing abundant water storage and movement. A 6-in.-diameter well (23-794) drilled to the same depth as borehole 23-932 but $150 \mathrm{ft}$ north was pumped at a rate of $100 \mathrm{gal} / \mathrm{min}$ (Lewis and Spitz, 1987). Well 23801 ( $200 \mathrm{ft}$ northwest of the borehole) was pumped at a rate of $10 \mathrm{gal} / \mathrm{min}$ with $6 \mathrm{ft}$ of drawdown.

Fracture-surface mineralogy in the upper half of the core $(<60 \mathrm{ft}$ below land surface) is dominated by clay minerals and limonite (especially to a depth of $30 \mathrm{ft}$ ), whereas that in the lower half is dominated by clay minerals only (pl. 2). The presence of trace quantities of limonite to a depth of $100 \mathrm{ft}$ indicates the presence of the leading edge of oxidizing water. The dominance of limonite to a depth of $30 \mathrm{ft}$ indicates relatively complete oxidation of iron-bearing minerals, and therefore, the circulation of strongly oxidizing ground water to at least this depth.

The spontaneous-potential and single-point-resistance logs obtained from borehole 23-932 indicate an apparent relation of resistance and potential to the number of fractures in the rocks (pl. 2). Sloto and others (1992) report that low resistance on a single-point-resistance log indicates the presence of abundant fractures. The sharp decrease in resistance and slight increase in the spontaneous potential at a depth of about $60 \mathrm{ft}$ coincides with the location of the semiconsolidated-clay zone; this response is typical for clays (Keys, 1990). The caliper log from site 1 is in agreement with the fracture-density histogram (pl. 2); it shows a displacement of about 0.2 in. at three depths (55-57 ft, 73-75 ft, and 100-104 ft)--all in the three sections in which the fracture-density histogram shows the highest density of fractures below the transition zone (pl. 2). The one anomalous peak of radioactivity in the core from borehole 23-932, between 104 and $106 \mathrm{ft}$, coincides with the 0.2 in. displacement on the caliper log.

Observation well 23-801 is adjacent to borehole $23-932$, which was sealed immediately after geophysical logging, and is completed to the same depth as the borehole. Water from the observation well was sampled for water-quality analysis. Calcium was the dominant major cation $(45 \mathrm{mg} / \mathrm{L})$; concentrations of magnesium and sodium $(12$ and $9.7 \mathrm{mg} / \mathrm{L}$, respectively) were low (app. C). Bicarbonate was the dominant major anion $(177 \mathrm{mg} / \mathrm{L}$, represented as an alkalinity of $145 \mathrm{mg} / \mathrm{L}$ ); concentrations of sulfate and chloride ( 15 and $11 \mathrm{mg} / \mathrm{L}$, respectively) were low. A Stiff diagram of the major-ion composition of the water sample illustrates the dominance of calcium and bicarbonate and the dilute nature of the ground water (fig. 8). The relatively low specific conductance $(350 \mu \mathrm{S} / \mathrm{cm})$ indicates that the water contained little dissolved mineral matter.

The DO content of the water was low $(0.3 \mathrm{mg} / \mathrm{L})$. Concentrations of ammonia $(0.05 \mathrm{mg} / \mathrm{L})$ and Kjeldahl nitrogen $(0.2 \mathrm{mg} / \mathrm{L})$ were greater than the MRL's, whereas the concentration of nitrate was not $(<0.1 \mathrm{mg} / \mathrm{L})$. Concentrations of iron and manganese were 370 and 290 $\mu \mathrm{g} / \mathrm{L}$, respectively. The high concentrations of ammonia, iron, and manganese indicate that ground water at this site is moderately reducing.

Barium and strontium were present in higher concentrations than any other trace element analyzed for in the ground-water sample collected at the site ( 390 and $410 \mu \mathrm{g} / \mathrm{L}$, respectively). The concentration of lithium was low $(7 \mu \mathrm{g} / \mathrm{L})$. No other trace elements were detected. 
Gross alpha-particle and gross beta-particle activities in the water sample from well 23-801 were 18.6 and $10 \mathrm{pCi} / \mathrm{L}$, respectively. The concentration of uranium in this sample was less than $0.4 \mu \mathrm{g} / \mathrm{L}$, whereas the concentrations of ${ }^{226} \mathrm{Ra}$ and ${ }^{228} \mathrm{Ra}$ were 4.81 and $2.7 \mathrm{pCi} / \mathrm{L}$, respectively. The concentration of ${ }^{222} \mathrm{Rn}$ was $3,910 \mathrm{pCi} / \mathrm{L}$.

\section{Site 2}

Stratigraphic columns with descriptions of cores and other lithologic characteristics of rocks penetrated by well 21-358 and borehole 21-359 at site 2 are given on plate 1. Lithology in well 21-358 is highly varied. Sandstones, which vary in color from a very pale orange (10YR8/2), pinkish-gray (5YR8/1), and gray pinkish-orange (5YR7/2) to a light brown (5YR6/1), predominate. Grain size varies from very fine to coarse. The fine-grained sandstones in the upper half of the core ( $<170 \mathrm{ft}$ below land surface) are generally very pale orange, whereas in the lower half they are pinkish-gray. The orange color in the shallow part of the core may result from weathering of iron-bearing minerals by circulating water. Some of the fine-grained sandstones are arkosic. The lower half of the core is dominated by sandstones and conglomerates (about 87 percent of the total thickness). The conglomerates are light gray (N8) or light to very pale orange (10YR8/2) and are composed of pebbles and cobbles. In general, the conglomerates are thin (2 to $3 \mathrm{ft}$ ). Most of the conglomerates are present at the base of a sandstone body overlying a red mudstone, indicating that they may have originated as gravel bars in scoured river channels. Other important rock types throughout the core are siltstones and mudstones, which vary in color from pale brown (5YR7/2) and pale red (5R6/2) to grayish-red (10R4/2) or medium dark gray (N4).

Massive bedding is common in all sandstones from well 21-358, regardless of grain size; however, the pale orange, fine- to medium-grained sandstones exhibit some laminar to crossbedded strata. The mudstones are massive to convoluted. Mottling is present in places.

The core from well 21-358 shows several distinct cyclic gradational sequences that typically fine upward from a conglomerate or coarse-grained sandstone to a pale brown mudstone (in the upper half of the core) or a pale red mudstone (in the lower half of the core). These sequences are found at depths of 25 to $72 \mathrm{ft}, 158$ to $192 \mathrm{ft}$, and 192 to $214 \mathrm{ft}$ and are separated by grayish-red to pale brown mudstones.

Styolites are abundant throughout the core but they are most commonly associated with the coarse-grained sandstones. Post-depositional calcite is locally abundant in the upper half of the core, especially in mudstones, but also in sandstones; it is absent from the lower half. Pyrite is associated with the pale brown mudstones in the interval from 121 to $140 \mathrm{ft}$.

The fracture-density histogram and the fracture-surface mineralogy chart, both beginning at a depth of $25 \mathrm{ft}$, and the BHTV $\log$ of well $21-358$ (pl. 2) indicate the presence of a slightly fractured transition zone located in the shallowest part of the well, at a depth of about 25 to $40 \mathrm{ft}$, located immediately below the regolith. This shallow, slightly fractured section coincides with the presence of a highly weathered coarse-grained sandstone. Bedrock is most densely fractured from 50 to $135 \mathrm{ft}$ below land surface; two highly fractured sections are present $(65-75 \mathrm{ft}$ and $115-130 \mathrm{ft})$ that contain more than 12 fractures per 5 -ft interval. The caliper log shows well-diameter enlargements that coincide with highly fractured sections at depths of 65 to $75 \mathrm{ft}, 98$ to $107 \mathrm{ft}$, and 125 to 
$130 \mathrm{ft}$. These sections all coincide with a facies change in the rock strata: conglomerate at the base of a fining-upward sequence, a fine- to medium-grained arkosic sandstone overlain by interbedded mudstone and sandstone, and a mudstone just below a conglomerate at the base of a fining-upward sequence, respectively. Low-angle fractures (bedding-plane fractures), as shown on the BHTV, coincide with increases in borehole diameter on the caliper log and large numbers of fractures on the fracture-density histogram. Below a depth of $135 \mathrm{ft}$, overall fracture density decreases sharply, and moderately fractured intervals (for example, at depths of 155-160 ft and 170-175 ft) are separated from highly fractured strata above $135 \mathrm{ft}$ by at least $20 \mathrm{ft}$ of unfractured or slightly fractured intervals (pl. 2). This decrease in fracturing below a depth of $135 \mathrm{ft}$ also is illustrated on the BHTV. No highly fractured intervals are present below $140 \mathrm{ft}$, and the caliper log shows no sharp increases in borehole diameter. Moderately fractured intervals were indicated by the fracture-density histogram for depths of 220 to $225 \mathrm{ft}$ and 280 to $285 \mathrm{ft}$.

The fractures are predominantly low-angle and are open throughout the core (pl. 2). Highangle fractures are abundant in the upper half of the core and are rare in the lower half. A single fissured zone at 130 to $132 \mathrm{ft}$ could be an avenue for water circulation at this depth. Local bleached zones at depths of 57 and $67 \mathrm{ft}$, in the uppermost sequence of sandstone and conglomerate, coincide with major fracture zones and may also indicate zones of water circulation.

The fracture-density data from the core correspond to the BHTV data (pl. 2), although the data from the core indicate a larger number of fractures than the BHTV data. The BHTV seems to be unable to distinguish multiple closely spaced individual narrow, low-angle open fractures from a single wide, low-angle open fracture. Also, the compressed vertical scale of the hand-sketched BHTV data shown on plate 2 prevents true-scale representation of the BHTV log. The depths of fractures in well 21-358 at site 2 identified with the BHTV (top, bottom, and center) and the associated dips and strikes are compiled in table D-1.

Fracture locations and densities were compared to the heat-pulse flowmeter (HPFM) data to determine which of the fractures are effective water conduits (pl. 2). Results obtained with the HPFM indicate that the direction of water flow under natural, unstressed conditions is downward. The maximum flow was centered at about $130 \mathrm{ft}$ near the fissured zone. Flow was detected as much as $200 \mathrm{ft}$ below land surface; below this depth, however, no 5 -ft interval contained more than four fractures, and most fractures were separated by several feet of unbroken rock, indicating that water circulation was unlikely. During pumping, water flows upward, across the upper $55 \mathrm{ft}$ of the saturated formation; no flow was detected below $110 \mathrm{ft}$. One explanation may be that the pressure differential produced by the pumping effectively counteracts the natural hydrostatic condition. Fractured intervals that contribute to flow during pumping, according to the HPFM data, are located at 52 to $54 \mathrm{ft}, 56$ to $60 \mathrm{ft}, 75$ to $78 \mathrm{ft}, 92.5$ to $100 \mathrm{ft}$, and 105 to $110 \mathrm{ft}$ below land surface (pl. 2). Most of the fractures in these intervals (table D-1) are parallel to bedding.

Fracture-surface mineralogy is dominated by limonite and clay in the upper $125 \mathrm{ft}$ of the core. Below $125 \mathrm{ft}$, clay minerals predominate on fracture surfaces, whereas limonite is present only in trace quantities. Calcite is rare above, and is generally absent below, $150 \mathrm{ft}$. Pyrite is found as a fracture-surface mineral in trace amounts in mudstones and siltstones at depths between 175 and $220 \mathrm{ft}$. 
Table D-1. Characteristics of fractures identified on borehole televiewer log, and measured flow rates at selected depths, site 2, well 21-358, Stockton Formation, south-central Newark Basin, New Jersey

[H, horizontal; V, vertical; N, north; S, south; NW, northwest; NE, northeast; SW, southwest; SE, southeast; NA, not applicable; $\mathrm{O}$, open; SD, sealed; $\mathrm{F}$ indicates flow measured near indicated depth; first number in parentheses is natural unstressed flow rate in gallons per minute, second number is depth of flow measurement in feet below land surface]

\begin{tabular}{|c|c|c|c|c|c|c|}
\hline \multicolumn{3}{|c|}{$\begin{array}{c}\text { Depth of fracture } \\
\text { (feet below land surface) }\end{array}$} & \multicolumn{3}{|c|}{ Fracture orientation } & \multirow{2}{*}{$\begin{array}{c}\text { Condition of } \\
\text { fracture, } \\
\text { and flow rate where } \\
\text { determined }\end{array}$} \\
\hline Top & Center & Bottom & & ip & $\begin{array}{c}\text { Strike } \\
\text { (degrees) }\end{array}$ & \\
\hline 45.50 & 45.50 & 45.50 & H & & NA & O \\
\hline 46.00 & 46.00 & 46.00 & H & & NA & $\mathrm{O}$ \\
\hline 47.00 & 47.00 & 47.00 & $\mathrm{H}$ & & NA & $\mathrm{O}$ \\
\hline 47.50 & 47.63 & 47.75 & 42 & $S$ & 69 & $\mathrm{O}$ \\
\hline 50.25 & 50.25 & 50.25 & $\mathbf{H}$ & & NA & 0 \\
\hline 50.50 & 50.50 & 50.50 & H & & NA & 0 \\
\hline 51.20 & 51.20 & 51.20 & $\mathrm{H}$ & & NA & O \\
\hline 52.50 & 52.50 & 52.50 & $\mathbf{H}$ & & NA & 0 \\
\hline 54.25 & 54.44 & 54.63 & 54 & $\mathrm{~N}$ & 285 & $\mathrm{O}$ \\
\hline 55.56 & 55.56 & 55.56 & $\mathrm{H}$ & & NA & $\mathrm{O} ; \mathrm{F}(.02,55)$ \\
\hline 56.40 & 56.45 & 56.50 & 20 & NW & 222 & $\mathrm{O}$ \\
\hline 57.00 & 57.10 & 57.20 & 36 & $\mathrm{~N}$ & 272 & $\mathrm{O}$ \\
\hline 57.50 & 57.50 & 57.50 & $\mathbf{H}$ & & NA & O \\
\hline 58.00 & 58.10 & 58.20 & 36 & SE & 42 & o \\
\hline 60.40 & 60.45 & 60.50 & 20 & $\mathbf{N}$ & 274 & $\mathrm{O} ; \mathrm{F}(.31,60)$ \\
\hline 61.37 & 61.49 & 61.62 & 42 & $\mathbf{N}$ & 274 & O \\
\hline 64.00 & 64.00 & 64.00 & $\mathrm{H}$ & & NA & O \\
\hline 64.00 & 64.08 & 64.15 & 28 & W & 186 & 0 \\
\hline 64.75 & 65.00 & 65.25 & 61 & SE & 60 & $O ; F(.34,65)$ \\
\hline 65.50 & 65.63 & 65.75 & 42 & SE & 33 & O \\
\hline 66.00 & 66.44 & 66.87 & 72 & S & 122 & $\mathrm{O}$ \\
\hline 66.87 & 67.06 & 67.25 & 54 & $\mathrm{~N}$ & 272 & 0 \\
\hline 68.25 & 68.25 & 68.25 & & $\mathrm{H}$ & NA & O \\
\hline 69.00 & 69.25 & 69.50 & 61 & $\mathrm{~N}$ & 294 & O \\
\hline 69.90 & 70.08 & 70.25 & 51 & $\mathrm{~N}$ & 294 & $0 ; \mathrm{F}(.33,70)$ \\
\hline
\end{tabular}


Table D-1. Characteristics of fractures identified on borehole televiewer log, and measured flow rates at selected depths, site 2, well 21-358, Stockton Formation, south-central Newark Basin, New Jersey-Continued

\begin{tabular}{|c|c|c|c|c|c|c|}
\hline \multicolumn{3}{|c|}{$\begin{array}{c}\text { Depth of fracture } \\
\text { (feet below land surface) }\end{array}$} & \multicolumn{3}{|c|}{ Fracture orientation } & \multirow{2}{*}{$\begin{array}{c}\text { Condition of } \\
\text { fracture, } \\
\text { and flow rate where } \\
\text { determined }\end{array}$} \\
\hline Top & Center & Bottom & $\begin{array}{r}D \\
\text { (deg }\end{array}$ & $\begin{array}{l}\text { ip } \\
\text { rees) }\end{array}$ & $\begin{array}{c}\text { Strike } \\
\text { (degrees) }\end{array}$ & \\
\hline 70.30 & 70.60 & 70.90 & 65 & NE & 330 & $\mathrm{O}$ \\
\hline 72.47 & 72.47 & 72.47 & $\mathrm{H}$ & & NA & $\mathrm{O}$ \\
\hline 72.87 & 72.94 & 73.00 & 25 & $\mathrm{~N}$ & 276 & $\mathrm{O}$ \\
\hline 73.00 & 73.08 & 73.15 & 28 & NE & 330 & O \\
\hline 73.25 & 73.50 & 73.75 & 61 & $\mathrm{~N}$ & 276 & 0 \\
\hline 77.00 & 77.05 & 77.10 & 20 & NW & 222 & $O ; F(.36,80)$ \\
\hline 83.62 & 84.25 & 84.87 & 77 & $S$ & 78 & SD \\
\hline 87.40 & 87.40 & 87.40 & $\mathrm{H}$ & & NA & $\mathrm{O} ; \mathrm{F}(.38,86)$ \\
\hline 88.10 & 88.10 & 88.10 & $\mathbf{H}$ & & NA & SD \\
\hline 88.25 & 88.38 & 88.50 & 42 & $\mathrm{~N}$ & 267 & $\mathrm{O}$ \\
\hline 90.50 & 90.56 & 90.62 & 23 & $\mathrm{~N}$ & 312 & $0 ; F(.36,89)$ \\
\hline 92.50 & 92.88 & 93.25 & 70 & S & 60 & SD \\
\hline 94.40 & 94.70 & 95.00 & 65 & $\mathrm{~S}$ & 96 & SD \\
\hline 97.50 & 97.50 & 97.50 & $\mathrm{H}$ & & NA & $0 ; F(.35,97)$ \\
\hline 98.15 & 98.15 & 98.15 & $\mathrm{H}$ & & NA & 0 \\
\hline 98.37 & 98.37 & 98.37 & $\mathrm{H}$ & & NA & 0 \\
\hline 98.75 & 98.75 & 98.75 & $\mathbf{H}$ & & NA & 0 \\
\hline 99.25 & 99.94 & 100.62 & 79 & $\mathrm{~S}$ & 78 & $\mathrm{O}$ \\
\hline 102.50 & 102.88 & 103.25 & 70 & $\mathrm{~S}$ & 78 & SD \\
\hline 104.00 & 106.50 & 109.00 & $\mathrm{~V}$ & & NA & $O ; F(.39,106)$ \\
\hline 112.75 & 113.25 & 113.75 & 74 & $\mathrm{~S}$ & 78 & 0 \\
\hline 119.50 & 119.63 & 119.75 & 42 & $\mathbf{N}$ & 294 & $0 ; \mathrm{F}(.50,119)$ \\
\hline 120.25 & 120.50 & 120.75 & 61 & $\mathrm{E}$ & 348 & 0 \\
\hline 120.87 & 120.94 & 121.00 & 25 & $\mathrm{~N}$ & 276 & 0 \\
\hline 123.00 & 123.00 & 123.00 & $\mathrm{H}$ & & NA & SD \\
\hline 124.50 & 124.50 & 124.50 & $\mathbf{H}$ & & NA & $0 ; \mathrm{F}(.47,125)$ \\
\hline 125.25 & 125.25 & 125.25 & $\mathrm{H}$ & & $\mathrm{NA}$ & $\mathrm{SD}$ \\
\hline 126.62 & 126.69 & 126.75 & 25 & W & 204 & 0 \\
\hline 127.00 & 127.19 & 127.37 & 53 & $\mathrm{~S}$ & 78 & 0 \\
\hline 127.50 & 127.56 & 127.62 & 23 & $\mathrm{~S}$ & 114 & 0 \\
\hline
\end{tabular}


Table D-1. Characteristics of fractures identified on borehole televiewer log, and measured flow rates at selected depths, site 2, well 21-358, Stockton Formation, south-central Newark Basin, New Jersey-Continued

\begin{tabular}{|c|c|c|c|c|c|c|}
\hline \multicolumn{3}{|c|}{$\begin{array}{c}\text { Depth of fracture } \\
\text { (feet below land surface) }\end{array}$} & \multicolumn{3}{|c|}{ Fracture orientation } & \multirow{2}{*}{$\begin{array}{c}\text { Condition of } \\
\text { fracture, } \\
\text { and flow rate where } \\
\text { determined }\end{array}$} \\
\hline Top & Center & Bottom & $\begin{array}{r}\mathrm{Di} \\
\text { (degr }\end{array}$ & $\begin{array}{l}\text { ip } \\
\text { rees) }\end{array}$ & $\begin{array}{c}\text { Strike } \\
\text { (degrees) }\end{array}$ & \\
\hline 128.37 & 128.56 & 128.75 & 54 & $\mathrm{~N}$ & 276 & 0 \\
\hline 129.10 & 129.55 & 130.00 & 73 & W & 204 & $\mathrm{O}$ \\
\hline 130.25 & 130.31 & 130.37 & 23 & $S$ & 78 & O \\
\hline 130.37 & 130.49 & 130.62 & 40 & $\mathrm{~N}$ & 267 & \\
\hline 132.00 & 132.05 & 132.10 & 20 & $\mathrm{~N}$ & 285 & $\mathrm{O} ; \mathrm{F}(.52,134)$ \\
\hline 138.15 & 138.20 & 138.25 & 20 & $\mathrm{~N}$ & 285 & 0 \\
\hline 142.25 & 142.25 & 142.25 & $\mathrm{H}$ & & NA & $\mathrm{O} ; \mathrm{F}(.45,144)$ \\
\hline 148.75 & 148.88 & 149.00 & 41 & $\mathrm{~N}$ & 276 & $\mathrm{O} ; \mathrm{F}(.46,147)$ \\
\hline 155.00 & 155.45 & 155.90 & 73 & $S$ & 60 & $\mathrm{O} ; \mathrm{F}(.28,150)$ \\
\hline 157.25 & 157.28 & 157.30 & 10 & SW & 132 & SD \\
\hline 162.00 & 162.00 & 162.00 & $\mathrm{H}$ & & NA & SD \\
\hline 164.25 & 164.38 & 164.50 & 42 & $\mathrm{~N}$ & 222 & 0 \\
\hline 164.52 & 164.52 & 164.52 & $\mathrm{H}$ & & NA & SD \\
\hline 165.25 & 165.50 & 165.75 & 61 & $\mathrm{~N}$ & 267 & $\mathrm{O} ; \mathrm{F}(.29,175)$ \\
\hline 181.25 & 181.38 & 181.50 & 42 & W & 168 & SD \\
\hline 188.00 & 188.25 & 188.50 & 61 & W & 168 & $\mathrm{O} ; \mathrm{F}(.30,185)$ \\
\hline 190.25 & 190.50 & 190.75 & 61 & $\mathrm{E}$ & 348 & 0 \\
\hline 194.70 & 194.85 & 195.00 & 47 & E & 348 & $\mathrm{SD} ; \mathrm{F}(.23,194)$ \\
\hline 200.25 & 200.50 & 200.75 & 61 & $S$ & 78 & SD \\
\hline 204.25 & 204.75 & 205.25 & 74 & SW & 132 & SD \\
\hline 205.90 & 205.90 & 205.90 & $\mathrm{H}$ & & NA & 0 \\
\hline 205.87 & 206.06 & 206.25 & 54 & S & 78 & SD \\
\hline 212.00 & 212.00 & 212.00 & $\mathrm{H}$ & & NA & SD \\
\hline 212.50 & 212.50 & 212.50 & $\mathrm{H}$ & & NA & SD \\
\hline 213.00 & 213.00 & 213.00 & $\mathrm{H}$ & & NA & SD \\
\hline 216.75 & 217.25 & 217.75 & 74 & W & 168 & SD \\
\hline 216.85 & 216.85 & 216.85 & $\mathrm{H}$ & & NA & SD \\
\hline 220.88 & 220.88 & 220.88 & $\mathrm{H}$ & & NA & $\mathrm{O}$ \\
\hline 222.25 & 222.25 & 222.25 & $\mathrm{H}$ & & NA & SD \\
\hline 223.37 & 223.37 & 223.27 & $\mathrm{H}$ & & NA & $\mathrm{O}$ \\
\hline
\end{tabular}


Table D-1. Characteristics of fractures identified on borehole televiewer log, and measured flow rates at selected depths, site 2, well 21-358, Stockton Formation, south-central Newark Basin, New Jersey-Continued

\begin{tabular}{|c|c|c|c|c|c|c|}
\hline \multicolumn{3}{|c|}{$\begin{array}{c}\text { Depth of fracture } \\
\text { (feet below land surface) }\end{array}$} & \multicolumn{3}{|c|}{ Fracture orientation } & \multirow{2}{*}{$\begin{array}{c}\text { Condition of } \\
\text { fracture, } \\
\text { and flow rate where } \\
\text { determined }\end{array}$} \\
\hline Top & Center & Bottom & $\begin{array}{r}\mathrm{Di} \\
\text { (degr }\end{array}$ & ip & $\begin{array}{c}\text { Strike } \\
\text { (degrees) }\end{array}$ & \\
\hline 223.62 & 223.62 & 223.62 & $\mathbf{H}$ & & NA & $\mathrm{O}$ \\
\hline 224.87 & 224.87 & 224.87 & $\mathbf{H}$ & & NA & $\mathrm{O}$ \\
\hline 230.37 & 231.06 & 231.75 & 79 & $S$ & 60 & $\mathrm{O}$ \\
\hline 233.00 & 233.00 & 233.00 & $\mathrm{H}$ & & NA & $S$ \\
\hline 233.10 & 233.30 & 233.50 & 55 & $S$ & 96 & $\mathbf{S}$ \\
\hline 246.35 & 246.49 & 246.62 & 44 & $\mathbf{N}$ & 276 & $S$ \\
\hline 253.87 & 253.87 & 253.87 & $\mathbf{H}$ & & NA & $S$ \\
\hline 255.62 & 255.62 & 255.62 & $\mathbf{H}$ & & NA & $\mathrm{S}$ \\
\hline 263.62 & 263.62 & 263.62 & $\mathbf{H}$ & & NA & $\mathrm{S}$ \\
\hline 269.25 & 269.25 & 269.25 & $\mathbf{H}$ & & NA & $\mathrm{O}$ \\
\hline 270.90 & 271.20 & 271.50 & 80 & W & 150 & O \\
\hline 272.37 & 272.76 & 273.15 & 71 & W & 168 & $\mathrm{~S}$ \\
\hline 273.00 & 273.43 & 273.87 & 73 & W & 168 & $S$ \\
\hline 275.00 & 275.75 & 276.50 & 80 & W & 186 & $S$ \\
\hline 287.50 & 287.50 & 287.50 & & $\mathrm{H}$ & NA & 0 \\
\hline 290.40 & 291.35 & 292.30 & 82 & W & 168 & o \\
\hline
\end{tabular}


Five zones of anomalously high levels of radioactivity are illustrated on the gamma log of well 21-358 (pls. 1 and 2). They are centered at depths of $62 \mathrm{ft}, 67 \mathrm{ft}, 173 \mathrm{ft}, 183 \mathrm{ft}$, and $285 \mathrm{ft}$. Each radioactive zone consists of a considerable thickness of strata, a result atypical of radioactive zones at the other sites. All major anomalous gamma peaks correlate with the basal conglomerate in fining-upward sequences in the core. In the section from 200 to $225 \mathrm{ft}$, a series of three small gamma peaks (multiple peaks for the second of the three) is associated with conglomerates and coarse-grained sandstones located near, but not at the base of, fining-upward gradational sequences that can be identified visually by sudden changes in grain size in an upward traverse of the core from silt to gravel. These three conglomerates probably are the most permeable strata in this section and likely were enriched in uranium by the same processes that enriched the conglomerates overlying siltstone elsewhere in the core.

The gamma log and stationary gamma spectra are shown in figure $\mathrm{D}-1$. The total integrated counts $\left(1,024\right.$ channels, energy $0-3 \mathrm{MeV}$, including the stabilization source of $\left.{ }^{133} \mathrm{Ba}\right)$ for each of five spectra are shown in table D-2. The total integrated counts of gamma activity for each of the anomalous spectra peaks at depths of $61.96 \mathrm{ft}, 182 \mathrm{ft}, 208.93 \mathrm{ft}$, and $272.51 \mathrm{ft}$ are about two times greater than the background spectra at a depth of $260 \mathrm{ft}$ for the same counting time. Four ${ }^{214} \mathrm{Bi}$ peaks $(0.609,1.120,1.764$, and $2.204 \mathrm{MeV})$ of the ${ }^{238} \mathrm{U}$ series and the ${ }^{40} \mathrm{~K}$ peak (1.46) are identified in the stationary gamma spectra for all depths shown in figure D-1 except the depth of $260 \mathrm{ft}$ in figure D-1D, where the 2.204 peak is not evident. This result indicates the presence of a concentration of the uranium-series progeny in the strata significantly above background levels at the depths of the anomalous gamma peaks.

The gamma log, BHTV, HPFM, and stationary gamma-spectra for a 10-ft section (60-70 $\mathrm{ft}$ ) are shown in figure 9 to illustrate how the logs can be used to identify a zone in the well where radioactive water is likely intercepted. The gamma and gamma spectral log indicate the presence of high concentrations of ${ }^{238} \mathrm{U}$-series radionuclides. The BHTV indicates the presence of numerous low-angle or horizontal (bedding-plane) fractures. The HPFM indicates that water is circulating in these fractures.

The dominant major cations in the water sample collected from well 21-358 at site 2 were sodium $(87 \mathrm{mg} / \mathrm{L})$ and calcium $(56 \mathrm{mg} / \mathrm{L})$; the dominant major anion was chloride $(230 \mathrm{mg} / \mathrm{L})$ (app. C). The concentration of bicarbonate was relatively low (alkalinity of $76 \mathrm{mg} / \mathrm{L}$ ). A Stiff diagram of the major-ion composition of this sample illustrates the dominance of sodium and chloride (fig. 8). The high specific conductance $(700 \mu \mathrm{S} / \mathrm{cm})$ indicates the presence of a significant amount of mineral matter in the sample.

The relatively high DO content of $3.8 \mathrm{mg} / \mathrm{L}$ indicates that the sampled well water is oxidizing. The concentration of nitrate $(4.1 \mathrm{mg} / \mathrm{L})$ greatly exceeded that of ammonia $(0.01 \mathrm{mg} / \mathrm{L})$. Concentrations of iron and manganese ( 39 and $27 \mu \mathrm{g} / \mathrm{L}$, respectively) were relatively low. The presence of DO and nitrate together with low concentrations of ammonia, iron, and manganese indicates that the water is oxic.

Barium and strontium were present in water from the well in higher concentrations than that of any other trace element whose concentration was determined $(290$ and $350 \mu \mathrm{g} / \mathrm{L}$, respectively). The concentration of lithium was low $(4 \mu \mathrm{g} / \mathrm{L})$. Aluminum was detected at a concentration of $30 \mu \mathrm{g} / \mathrm{L}$. Although the slightly acidic $\mathrm{pH}(6.4)$ of the water from this well probably enhanced the solubility of aluminum, no other trace elements (several of which are soluble in acidic water) were detected. 


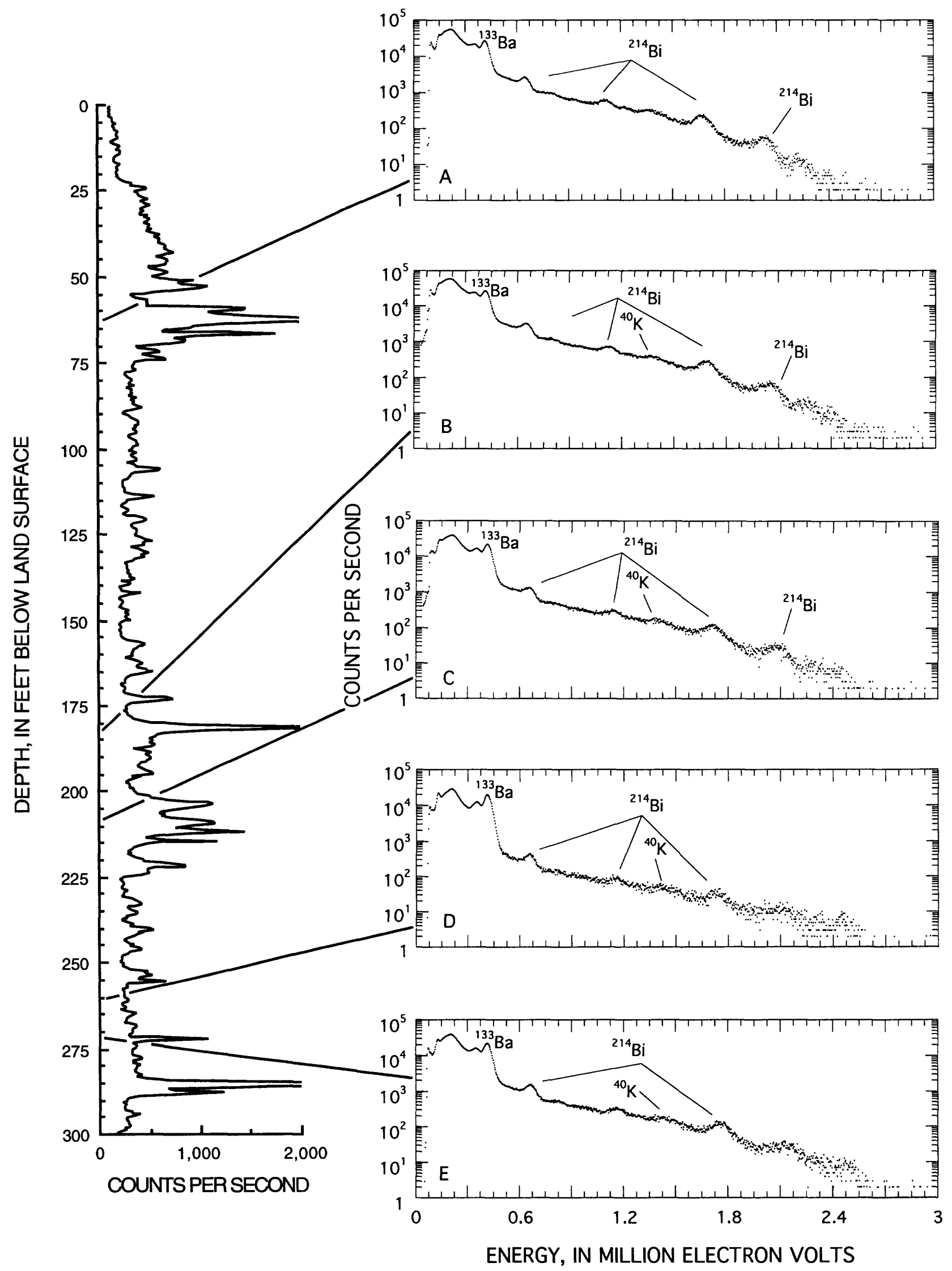

Figure D-1. Gamma log of well 21-358, site 2, Stockton Formation, south-central Newark Basin, New Jersey, and stationary gamma spectra at the following depths, in feet: (A) 61.96, (B) 182.0, (C) 208.93, (D) 260.0, and (E) 272.51. 
Table D-2. Characteristics of stationary gamma spectra measured at sites $2,3,4$, and 5, Stockton Formation and lower part of the Passaic Formation, south-central Newark Basin, New Jersey

\begin{tabular}{|c|c|c|c|c|}
\hline $\begin{array}{l}\text { Site number/ } \\
\text { well number }\end{array}$ & $\begin{array}{c}\text { Depth of } \\
\text { spectra } \\
\text { (feet below } \\
\text { land surface) }\end{array}$ & $\begin{array}{l}\text { Counting } \\
\text { time } \\
\text { (seconds) }\end{array}$ & $\begin{array}{c}\text { Total } \\
\text { integrated } \\
\text { counts }\end{array}$ & $\begin{array}{c}\text { Number } \\
\text { of } \\
\text { channels }\end{array}$ \\
\hline \multirow[t]{5}{*}{$2 / 21-358$} & 61.96 & 1,000 & $3,810,876$ & 1,024 \\
\hline & 182.00 & 1,000 & $4,321,032$ & 1,024 \\
\hline & 208.93 & 1,000 & $2,778,012$ & 1,024 \\
\hline & 260.00 & 1,000 & ${ }^{2} 1,912,711$ & 1,024 \\
\hline & 272.51 & 1,000 & $2,818,529$ & 1,024 \\
\hline \multirow[t]{3}{*}{$3 / 21-290$} & 133.96 & 500 & $2,636,879$ & 1,024 \\
\hline & 140.53 & 500 & $5,337,995$ & 1,024 \\
\hline & 172.25 & 251 & $9,617,571$ & 1,024 \\
\hline \multirow[t]{5}{*}{$4 / 19-251$} & 33.18 & 1,000 & $3,025,005$ & 1,024 \\
\hline & 48.00 & 1,000 & $2,031,788$ & 1,024 \\
\hline & 72.81 & 1,000 & $2,232,479$ & 1,024 \\
\hline & 172.98 & 1,000 & $2,218,526$ & 1,024 \\
\hline & 193.30 & 1,000 & $2,812,356$ & 1,024 \\
\hline \multirow[t]{7}{*}{$4 / 19-250$} & 18.75 & 1,000 & $2,581,870$ & 1,024 \\
\hline & 102.50 & 500 & $2,669,229$ & 1,024 \\
\hline & 125.50 & 500 & $3,427,502$ & 1,024 \\
\hline & 229.00 & 500 & $1,939,639$ & 1,024 \\
\hline & 285.00 & 1,000 & ${ }^{2} 1,988,990$ & 1,024 \\
\hline & 345.01 & 1,000 & $2,049,702$ & 1,024 \\
\hline & 391.75 & 500 & $1,992,365$ & 1,024 \\
\hline \multirow[t]{2}{*}{$5 / 23-1083$} & 39.00 & 1,000 & $13,387,362$ & 1,024 \\
\hline & 53.72 & 1,000 & $2,539,844$ & 1,024 \\
\hline
\end{tabular}

'Value includes the barium-133 source that is used for stabilization of drift and all lowenergy noise counts.

${ }^{2}$ No anomalous gamma peak. 
The water sample from well 21-358 contained high levels of radioactivity. Gross alphaparticle activity was $32 \mathrm{pCi} / \mathrm{L}$, and gross beta-particle activity was $21 \mathrm{pCi} / \mathrm{L}$. Radium-226 was detected at a concentration of $3.2 \mathrm{pCi} / \mathrm{L}$, but the concentration of ${ }^{228} \mathrm{Ra}$ was below the MRL $(0.67$ $\mathrm{pCi} / \mathrm{L}$ ). The concentration of ${ }^{222} \mathrm{Rn}$, at $32,100 \mathrm{pCi} / \mathrm{L}$, was extremely high. Uranium isotopes were detected in a moderate concentration (sum of $6.4 \mathrm{pCi} / \mathrm{L}$ ). The presence of tritium in high concentrations $(90 \mathrm{pCi} / \mathrm{L})$ indicates that the water collected from the borehole is of recent (post-1960) origin (Hendry, 1988).

Several volatile organic compounds were detected in water from well 21-358, including chloroform, 1,1,1-dichloroethane, and 1,1,1-trichloroethane. The concentration of 1,1,1-trichloroethane $(51 \mu \mathrm{g} / \mathrm{L})$ is much greater than the USEPA MCL (U.S. Environmental Protection Agency, 1994) for this contaminant.

A detailed description of the core from borehole 21-359 is given on plate 1 . The dominant lithology, as in the core recovered from well $21-358$, is sandstone. The sandstones are the same shades of pale orange and pinkish-gray to light gray as sandstones in well 21-358. Most of the sandstones are arkosic and predominantly medium-grained; however, both fine- and coarsegrained sandstones also are present: Color does not correlate with any specific grain size. Conglomerates are thin, typically 2 to $3 \mathrm{ft}$ in thickness, and generally are pinkish-gray. Pebbles dominate; minor amounts of cobbles also are present. The mudstones are grayish-red to grayishred purple to pale brown and grayish-brown in color. Siltstones are a minor component of the core and generally are medium dark gray to pale red.

In general, bedding in the sandstones is massive; cross-bedding is rare. The mudstones are massive to convoluted and laminated in places. All conglomerates are massively bedded. The siltstones are predominantly massive, but are laminated in places. In the depth interval from 105 to $110 \mathrm{ft}$, both laminated and cross-bedded strata are present. Mudstones commonly exhibit tracefossil and depositional-bedding features, such as worm burrows, root casts, and mudcracks, that are filled with calcite and, in places, limonite; the sandstones, however, show no visible evidence of bioturbation.

The rocks penetrated by borehole 21-359, like those penetrated by well 21-358, contain several distinct cycles of gradational sequences. Four complete fining-upward sequences, which consist of a basal conglomerate or coarse-grained sandstone capped with a mudstone, are present in the sections from 101 to $103 \mathrm{ft}, 155$ to $161 \mathrm{ft}, 257$ to $269 \mathrm{ft}$, and 269 to $300 \mathrm{ft}$ below land surface. The four sequences are separated by series of partial fining-upward sequences that were likely beveled after deposition.

Macroscopic diagenetic textures and color changes are more common in the core from borehole 21-359 than in that from nearby well 21-358. Styolites are abundant in the sandstones and conglomerates but are not found in the mudstones. Bleached zones are present in a pale brown mudstone at $52 \mathrm{ft}$; two bleached zones are present in the section from 362 to $370 \mathrm{ft}$ in a red mudstone; and a bleached sandstone is located at a depth of $157 \mathrm{ft}$. Calcite speckling in the core is rare but, where present, is typically associated with mudstones and siltstones, whereas pyrite, which is also rare, is associated with sandstones. Several organic seams (at $293 \mathrm{ft}, 401 \mathrm{ft}$, and 431 $\mathrm{ft}$ ) are interbedded in the lower half of the core (below $220 \mathrm{ft}$ ), and trace amounts of organic material are found throughout the core. 
Caliper, spontaneous-potential, single-point-resistance, and gamma logs were recorded in the adjacent production well 21-383. All logs from the production well, the fracture-density histogram, and the fracture-surface-mineralogy data from the cores from borehole 21-359 are shown on plate 2. A highly fractured transition zone, present from 30 to $50 \mathrm{ft}$ below the regolith in borehole 21-359, is illustrated in the fracture-density histogram, which begins at a depth of $30 \mathrm{ft}$. This transition zone may have as few as 7 and as many as 21 fractures per 5-ft interval. Eight fissured zones are present at depths of 45.5 to $46.5 \mathrm{ft}, 57$ to $58 \mathrm{ft}, 63.5$ to $64.5 \mathrm{ft}, 68$ to $70 \mathrm{ft}, 70.5$ to $72.5 \mathrm{ft}, 73$ to $74 \mathrm{ft}, 78.5$ to $79.5 \mathrm{ft}$, and 83.5 to $84 \mathrm{ft}$. Many minor displacements in the caliper log were recorded in the highly fractured transition zone and where the fissured zones are present. The major displacement on the caliper $\log (3 \mathrm{in}$. in the depth interval from 57 to $58 \mathrm{ft}$ ) correlates with the most highly fractured interval in the histogram. The number of fractures in the 55-to-60-ft depth interval totals 20 , in addition to the fissured zone that is present in the section. This highly fractured interval, which is in a fine-grained arkosic sandstone, also shows a positive deflection on the spontaneous-potential log and low values of resistance, the combination of which indicates the probable presence of a water-bearing fracture zone. The shallowest highly fractured section (depth 30 to 50 $\mathrm{ft}$ ) and fissured zone (depth 45.5 to $46.5 \mathrm{ft}$ ) coincides with mudstone grading upwards into a coarseto fine-grained, massive sandstone. The core contains no highly fractured sections below $125 \mathrm{ft}$, and the total number of fractures per 5-ft interval typically is five or less. Two fissured zones are present in the section from 350 to $360 \mathrm{ft}$. The deep fractured section $(350-360 \mathrm{ft})$ and the fissured zones ( 353 and $354 \mathrm{ft}$ ) coincide with a medium-grained styolized sandstone.

The core is dominated by low-angle fractures, and, as in the core from well 21-358, highangle open fractures are more common in the upper half (above $220 \mathrm{ft}$ ) of the core than in the lower half. High-angle fractures sealed with calcite are common at depths of 325 to $335 \mathrm{ft}$ and 365 to $370 \mathrm{ft}$.

Fracture-surface mineralogy in the upper half of the core is dominated by limonite, clay, and trace quantities of calcite. Limonite dominates to a depth of $95 \mathrm{ft}$, below which it is present only in trace quantities or is absent. Chlorite coats the fractures in the section from 125 to $150 \mathrm{ft}$; this mineral was not present in the fractures from the core recovered from borehole 21-358.

Calcite, clay, and trace amounts of pyrite are the only fracture-coating minerals in the lower half of the core. These data indicate a penetration depth of about $95 \mathrm{ft}$ for oxidizing water.

Several zones of anomalously high radioactivity and many zones of radioactivity slightly greater than background were recorded on the gamma log. A series of four anomalously high gamma peaks in the section from 130 to $170 \mathrm{ft}$ coincide with the presence of styolized conglomerates and coarse-grained sandstones (pl. 1). Another set of anomalously high gamma peaks ( $>500$ cps) (pl. 1) in the section from 295 to $305 \mathrm{ft}$ also are associated with conglomerates, although styolites are absent. The third set of anomalously high gamma peaks, in the section from 420 to 430 $\mathrm{ft}$, are associated with fine-grained styolized arkosic sandstone interspersed with mudstone lenses. Two gamma peaks, each less than $500 \mathrm{cps}$ (pl. 1), were recorded at a depth of $270 \mathrm{ft}$ and at a depth of $388 \mathrm{ft}$, each in a thin, featureless conglomerate. 
Yields for observation well 21-358 are moderate; the well was pumped at $15 \mathrm{gal} / \mathrm{min}$ for 4 hours and had a 100 - $\mathrm{ft}$ drawdown. The estimated specific capacity is $0.15(\mathrm{gal} / \mathrm{min}) / \mathrm{ft}$ of drawdown. Specific capacities of nearby wells range from 0.02 to $0.53(\mathrm{gal} / \mathrm{min}) / \mathrm{ft}$ of drawdown. Well yield was not measured in borehole 21-359; however, the adjacent 8-in.-diameter industrial well (21-383) produced $100 \mathrm{gal} / \mathrm{min}$.

\section{Site 3}

Lithology in borehole 21-290 is dominated by a brownish-gray (5YR4/1) to grayish-red purple (5RP4/2) mudstone, which becomes medium gray (N5) and then, at a depth of $125 \mathrm{ft}$, dark gray (N3). The dark gray mudstone is $49 \mathrm{ft}$ thick in the core. The bottom $10 \mathrm{ft}$ of core consists of interbedded brownish-gray and medium-gray mudstone (pl. 3).

Bedding in the reddish mudstones is predominantly massive with some convoluted and laminar beds. The dark gray mudstones are massive but are intercalated with fine, white, thinly bedded, carbonate-rich silt laminae at a depth of 139 to $142 \mathrm{ft}$. Calcite-filled mudcracks are present from 85 to $95 \mathrm{ft}$ and from 180 to $185 \mathrm{ft}$. Local calcite speckling and mottling are common in mudstones throughout the core, whereas local pyrite speckling is common only in the lower half of the core (below $120 \mathrm{ft}$ ). Large euhedral pyrite crystals are found in the dark gray mudstones.

Only one sample from site 3 (borehole 21-290 at $170 \mathrm{ft}$ ) was selected for whole-rock chemical analysis (app. B-1). The sample contained 2.1 percent inorganic carbon and 1.41 percent organic carbon. Concentrations of calcium and aluminum were 3.99 and 8.15 percent, respectively, of the sample. Concentrations of iron and manganese, 4.6 percent and $1,030 \mu \mathrm{g} / \mathrm{g}$, respectively, were greater than those in any of the samples analyzed from the Stockton Formation at site 1 . The trace elements vanadium, zinc, lithium, molybdenum, and strontium were all present at higher concentrations in this sample from the Passaic Formation than in any of the samples from the Stockton Formation at site 1 or, in general, in samples from red mudstone at site 5 . Concentrations of molybdenum $(102 \mu \mathrm{g} / \mathrm{g})$ and arsenic $(240 \mu \mathrm{g} / \mathrm{g})$ were higher but concentrations of lithium were lower than the concentrations in other mudstone samples from the Newark Basin that were analyzed by Dean (1988).

Eight whole-rock samples from borehole 21-290 were selected for determination of radioactivity by gamma-spectral analysis (app. B-2). The depths of samples are identified on pl. 3 . Equivalent uranium was highly enriched relative to equivalent thorium in the sample from $170.1 \mathrm{ft}$. The concentration of thorium was greater than the concentration of uranium at $111.0 \mathrm{ft}, 122.9 \mathrm{ft}$, and $178.1 \mathrm{ft}$. In the two shallower samples, the thorium-to-uranium ratio was about 4.0 , a ratio that is typical of continental sedimentary deposits. The total count of gross-gamma was greater at 170.1 $\mathrm{ft}$ than at any other depth from which samples were collected in this borehole; this is approximately the same depth at which the maximum gamma peak was recorded on the geophysical $\log$ (pl. 3 ).

The fracture-density histogram for borehole 21-290, which begins at a depth of $20 \mathrm{ft}$, shows that the rocks are moderately fractured throughout nearly the entire stratigraphic section (pl. 4); however, there is considerable variability in the fracture density in selected zones, ranging from a slightly fractured section ( 125 to $150 \mathrm{ft}$ ) to a highly fractured section (160 to $170 \mathrm{ft}$ ). The highly fractured transition zone ( 20 to $50 \mathrm{ft}$ ), immediately below the weathered regolith, is apparent on 
the caliper log from the adjacent unused irrigation well $21-159$, where many displacements are visible (pl. 4); as many as 15 fractures per individual 5-ft interval were observed. The greatest caliper displacement, however, is at $68 \mathrm{ft}$, indicating the presence of a large fracture. Large fractures are visible on the BHTV log from adjacent well 21-159 at depths of 25 to $30 \mathrm{ft}$ and 150 and $170 \mathrm{ft}$. A large vertical fracture recorded by the BHTV in the section from 80 to $90 \mathrm{ft}$ also is represented in the appropriate 5-ft intervals on the fracture-density histogram. Within the section 145 to $170 \mathrm{ft}$ are five fissured zones that vary in thickness. The fissured zones are also well-defined by the BHTV $\log$ at 150 to $170 \mathrm{ft}$. The caliper log shows many displacements of about 2 in. in the depth intervals that, in general, coincide with each fissured zone (pl. 4). In the 145-to-150-ft interval, the fissured zone is 9 in. thick; in the 150 -to- 155 - $\mathrm{ft}$ interval, it is $1.3 \mathrm{ft}$ thick; in the 160 to-165-interval, it is about 6 in. thick; and both fissured zones in the 165-to- $170 \mathrm{ft}$ interval are 6 in. thick. The fissured zones coincide with a massive gray mudstone.

The fractures are predominantly low-angle open, but a few high-angle open and high-angle sealed fractures are distributed throughout the core. BHTV data from adjacent well 21-159 confirm this distribution of fracture orientations. Information on the depths of fractures identified on the BHTV log and their orientation is compiled in table D-3. The total number of fractures decreases and the number of high-angle fractures increases in the lower part of the core (below 100 $\mathrm{ft})$. Large horizontal and low-angle fractures identified on the BHTV log at depths of 150, 155, 161,162 , and $171 \mathrm{ft}$ (table D-3) coincide approximately with the fissured zones. These fissured zones, however, may not contain water because they are separated from the shallower highly fractured section by $30 \mathrm{ft}$ of only slightly fractured strata (pl. 4). The gradual increase in resistance on the single-point-resistance logs corresponds, in general, to the decrease in the number of fractures with depth (pl. 4). Sudden decreases in resistance in well 21-159 at depths of 125, 150, and $175 \mathrm{ft}$ correlate to the presence of extensive fracturing. These deflections could indicate the presence of water or could be the result of clay and pyrite in some of the fissured zones. The temperature log (pl. 4) indicates a significant change in temperature at a depth of $85 \mathrm{ft}$, where the large vertical fracture (from 80 to $90 \mathrm{ft}$ ) intercepts a highly fractured section that contains many low-angle open fractures. The change in temperature indicates that a zone of major water production is likely present at a depth of $85 \mathrm{ft}$. The absence of other changes in temperature in the well-water temperature profile also indicates the many fissured zones within the section from 145 to $170 \mathrm{ft}$ may not produce any water.

Calcite, clay, and limonite are the dominant minerals on fracture surfaces in the upper 125 $\mathrm{ft}$ of the core. Below $125 \mathrm{ft}$, calcite and pyrite are present together. Clay is found in trace amounts below $125 \mathrm{ft}$, but limonite is absent, indicating that the oxidizing waters do not circulate below this depth.

Two zones of anomalously high radioactivity were found in borehole 21-290. The shallower of the two zones, in the interval from 140 to $145 \mathrm{ft}$, coincides with intercalated laminated black and white mudstone and siltstone. The deeper zone, in the interval from 172 to $176 \mathrm{ft}$ correlates with black mudstone in which alternating light and dark bands are absent. These radioactive zones are separated by a highly fractured section of strata, but are not themselves intersected by fractures, as evidenced by the caliper log, fracture-density histogram, and BHTV log (pl. 4), none of which shows geophysical response indicative of fractures at these depths. The response on the resistance $\log$ at a depth of about $175 \mathrm{ft}$ may result from the presence of pyrite or clay. 
Table D-3. Characteristics of fractures identified on borehole televiewer log, site 3, well 21-159, lower part of the Passaic Formation, south-central Newark Basin, New Jersey

[H, horizontal; V, vertical; N, north; S, south; NW, northwest; NE, northeast; SW, southwest; SE, southeast; NA, not applicable; $\mathrm{O}$, open; $\mathrm{SD}$, sealed]

\begin{tabular}{|c|c|c|c|c|c|c|}
\hline \multicolumn{3}{|c|}{$\begin{array}{c}\text { Depth of fracture } \\
\text { (feet below land surface) }\end{array}$} & \multicolumn{3}{|c|}{ Fracture orientation } & \multirow[b]{2}{*}{$\begin{array}{l}\text { Condition } \\
\text { of fracture }\end{array}$} \\
\hline Top & Center & Bottom & $\begin{array}{r}\mathrm{Di} \\
(\mathrm{deg}\end{array}$ & ip & $\begin{array}{c}\text { Strike } \\
\text { (degrees) }\end{array}$ & \\
\hline $31: 00$ & 31.71 & 32.42 & 57 & $\mathbf{N}$ & 237 & 0 \\
\hline 34.90 & 35.45 & 36.00 & 50 & W & 150 & \\
\hline 37.58 & 38.29 & 39.00 & 57 & S & 78 & O \\
\hline 39.00 & 39.00 & 39.00 & & $\mathrm{H}$ & NA & SD \\
\hline 40.50 & 41.75 & 43.00 & 69 & S & 78 & SD \\
\hline 41.25 & 42.46 & 43.67 & 68 & S & 96 & O \\
\hline 44.00 & 44.00 & 44.00 & & $\mathrm{H}$ & NA & 0 \\
\hline 46.42 & 46.71 & 47.00 & 30 & $\mathbf{N}$ & 261 & SD \\
\hline 49.83 & 53.29 & 56.75 & 82 & $S$ & 96 & 0 \\
\hline 50.00 & 50.00 & 50.00 & & $\mathrm{H}$ & NA & O \\
\hline 50.50 & 50.50 & 50.50 & & $\mathrm{H}$ & NA & 0 \\
\hline 51.00 & 51.00 & 51.00 & & $\mathrm{H}$ & NA & $\mathrm{O}$ \\
\hline 51.40 & 51.40 & 51.40 & & $\mathrm{H}$ & NA & 0 \\
\hline 52.00 & 52.00 & 52.00 & & $\mathbf{H}$ & NA & $\mathrm{O}$ \\
\hline 61.50 & 61.50 & 61.50 & & $\mathrm{H}$ & NA & 0 \\
\hline 63.00 & 64.58 & 66.17 & 74 & S & 78 & 0 \\
\hline 67.33 & 67.58 & 67.83 & 29 & S & 114 & 0 \\
\hline 67.83 & 69.42 & 71.00 & 74 & S & 96 & 0 \\
\hline 72.00 & 72.00 & 72.00 & & $\mathrm{H}$ & NA & 0 \\
\hline 73.00 & 73.25 & 73.50 & 28 & W & 150 & 0 \\
\hline 77.00 & 77.00 & 77.00 & & $\mathrm{H}$ & NA & 0 \\
\hline 80.00 & 85.50 & 91.00 & 85 & S & 114 & 0 \\
\hline 93.00 & 93.00 & 93.00 & & $\mathrm{H}$ & NA & 0 \\
\hline 95.50 & 95.50 & 95.50 & & $\mathbf{H}$ & NA & 0 \\
\hline 95.75 & 95.75 & 95.75 & & $\mathrm{H}$ & NA & 0 \\
\hline 98.75 & 98.75 & 98.75. & & $\mathrm{H}$ & NA & 0 \\
\hline 103.00 & 103.67 & 104.33 & 56 & W & 168 & 0 \\
\hline 106.00 & 106.45 & 106.9 & 45 & S & 123 & 0 \\
\hline 113.00 & 113.00 & 113.00 & & $\mathrm{H}$ & NA & 0 \\
\hline 114.33 & 114.33 & 114.33 & & $\mathrm{H}$ & NA & 0 \\
\hline
\end{tabular}


Table D-3. Characteristics of fractures identified on borehole televiewer log, site 3, well 21-159, lower part of the Passaic Formation, south-central Newark Basin, New Jersey--Continued

\begin{tabular}{|c|c|c|c|c|c|c|}
\hline \multicolumn{3}{|c|}{$\begin{array}{c}\text { Depth of fracture } \\
\text { (feet below land surface) }\end{array}$} & \multicolumn{3}{|c|}{ Fracture orientation } & \multirow[b]{2}{*}{$\begin{array}{l}\text { Condition } \\
\text { of fracture }\end{array}$} \\
\hline Top & Center & Bottom & $\begin{array}{r}\mathrm{Di} \\
\text { (degr }\end{array}$ & $\begin{array}{l}\text { ip } \\
\text { rees) }\end{array}$ & $\begin{array}{c}\text { Strike } \\
\text { (degrees) }\end{array}$ & \\
\hline 115.58 & 119.38 & 123.17 & 83 & S & 96 & $\mathrm{O}$ \\
\hline 126.75 & 127.21 & 127.67 & 43 & $\mathbf{N}$ & 312 & 0 \\
\hline 149.83 & 152.42 & 155.00 & 80 & $\mathrm{~W}$ & 168 & $\mathrm{O}$ \\
\hline 157.00 & 159.37 & 161.75 & & V & NA & $\mathrm{O}$ \\
\hline 161.25 & 161.92 & 161.92 & 37 & $\mathrm{~N}$ & 294 & $\mathrm{O}$ \\
\hline 162.25 & 162.54 & 162.83 & 33 & $\mathrm{E}$ & 348 & O \\
\hline 165.00 & 166.75 & 168.50 & 75 & S & 96 & $\mathrm{O}$ \\
\hline 167.00 & 169.17 & 171.33 & 78 & $S$ & 105 & 0 \\
\hline 171.00 & 171.00 & 171.00 & & $\mathrm{H}$ & NA & $\mathrm{O}$ \\
\hline 172.00 & 172.00 & 172.00 & & $\mathrm{H}$ & NA & O \\
\hline 180.00 & 180.75 & 181.50 & 59 & W & 168 & $\mathrm{O}$ \\
\hline 181.50 & 182.00 & 182.50 & 48 & W & 168 & $\mathbf{O}$ \\
\hline 183.50 & 184.05 & 184.60 & 50 & W & 168 & $\mathbf{O}$ \\
\hline 185.30 & 185.55 & 185.80 & 29 & S & 96 & SD \\
\hline 187.75 & 193.79 & 199.83 & 86 & $S$ & 105 & 0 \\
\hline
\end{tabular}


The peaks and background energies of the gamma log for adjacent well 21-159 (fig. D-2) are identified by using stationary gamma spectra. The stationary gamma spectra are at (A) 133.96 $\mathrm{ft}$, where significant ${ }^{40} \mathrm{~K}$ and ${ }^{208} \mathrm{Tl}$ peaks are present along with less prominent ${ }^{214} \mathrm{Bi}$ peaks; (B) $140.53 \mathrm{ft}$, where four ${ }^{214} \mathrm{Bi}$ peaks are prominent in addition to the ${ }^{40} \mathrm{~K}$, and ${ }^{208} \mathrm{Tl}$ peaks; and (C) $172.25 \mathrm{ft}$, where prominent ${ }^{214} \mathrm{Bi}$ peaks are present in addition to a ${ }^{40} \mathrm{~K}$ peak that is barely greater in value than background and, hence, is almost unidentifiable. The total integrated counts (for 1,024 channels, energy $0-3 \mathrm{MeV}$, including the stabilization source of ${ }^{133} \mathrm{Ba}$ of spectra) recorded at. $172.25 \mathrm{ft}$, are about 4 times the counts at $133.96 \mathrm{ft}$ and 1.8 times the counts at $140.53 \mathrm{ft}$. Counting time at 172.25 was one-half that of the other two spectra at the other depths (table D-2). These results indicate strong uranium enrichment at depths of about 140 and $172 \mathrm{ft}$.

Unused irrigation wells 21-159 and 21-289 are located near borehole 21-290, which was sealed immediately after geophysical logging. Well $21-289$ is open at about the same depth as borehole 21-290 and was assumed to yield water that would be representative of water from the borehole. Therefore, water samples were collected from well $21-289$. Calcium $(44 \mathrm{mg} / \mathrm{L})$ was the dominant cation (app. C); concentrations of magnesium and sodium ( 16 and $11 \mathrm{mg} / \mathrm{L}$, respectively) were low. Bicarbonate was the dominant anion, but its concentration was relatively low (alkalinity, $127 \mathrm{mg} / \mathrm{L}$ ). Concentrations of sulfate and chloride ( 17 and $13 \mathrm{mg} / \mathrm{L}$, respectively) also were low. A Stiff diagram of the major-ion composition of the water sample illustrates the dominance of calcium and bicarbonate and the relatively dilute nature of the water (fig. 8). The specific conductance of $387 \mu \mathrm{S} / \mathrm{cm}$ signifies that the water contains dissolved mineral matter in amounts roughly typical of ground water in the Newark Basin (Szabo and Zapecza, 1987).

The DO content of the water sample $(3.6 \mathrm{mg} / \mathrm{L})$ indicates that the water is oxidizing. Concentrations of iron and manganese ( 3 and $10 \mu \mathrm{g} / \mathrm{L}$, respectively) were low, as is typical of oxidizing water. The $\mathrm{pH}$ was 7.8 , indicating slightly alkaline water.

Among the trace elements analyzed for, barium and strontium were present in the highest concentrations ( 120 and $340 \mu \mathrm{g} / \mathrm{L}$, respectively). Lithium and zinc were detected at concentrations of $19 \mu \mathrm{g} / \mathrm{L}$ and $37 \mu \mathrm{g} / \mathrm{L}$, respectively.

Radioactivity in the water sample from well 21-289 was low despite the high radioactivity of the strata penetrated by the well as indicated by results of detailed analysis of the rock core recovered from adjacent borehole 21-290. Concentrations of uranium and ${ }^{226} \mathrm{Ra}$ were low $(1.5 \mu \mathrm{g} / \mathrm{L}$ and $<0.6 \mathrm{pCi} / \mathrm{L}$, respectively). Gross alpha-particle and gross beta-particle activities were 2.50 and $1.9 \mathrm{pCi} / \mathrm{L}$, respectively. The concentration of ${ }^{222} \mathrm{Rn}$ was $1,370 \mathrm{pCi} / \mathrm{L}$. 


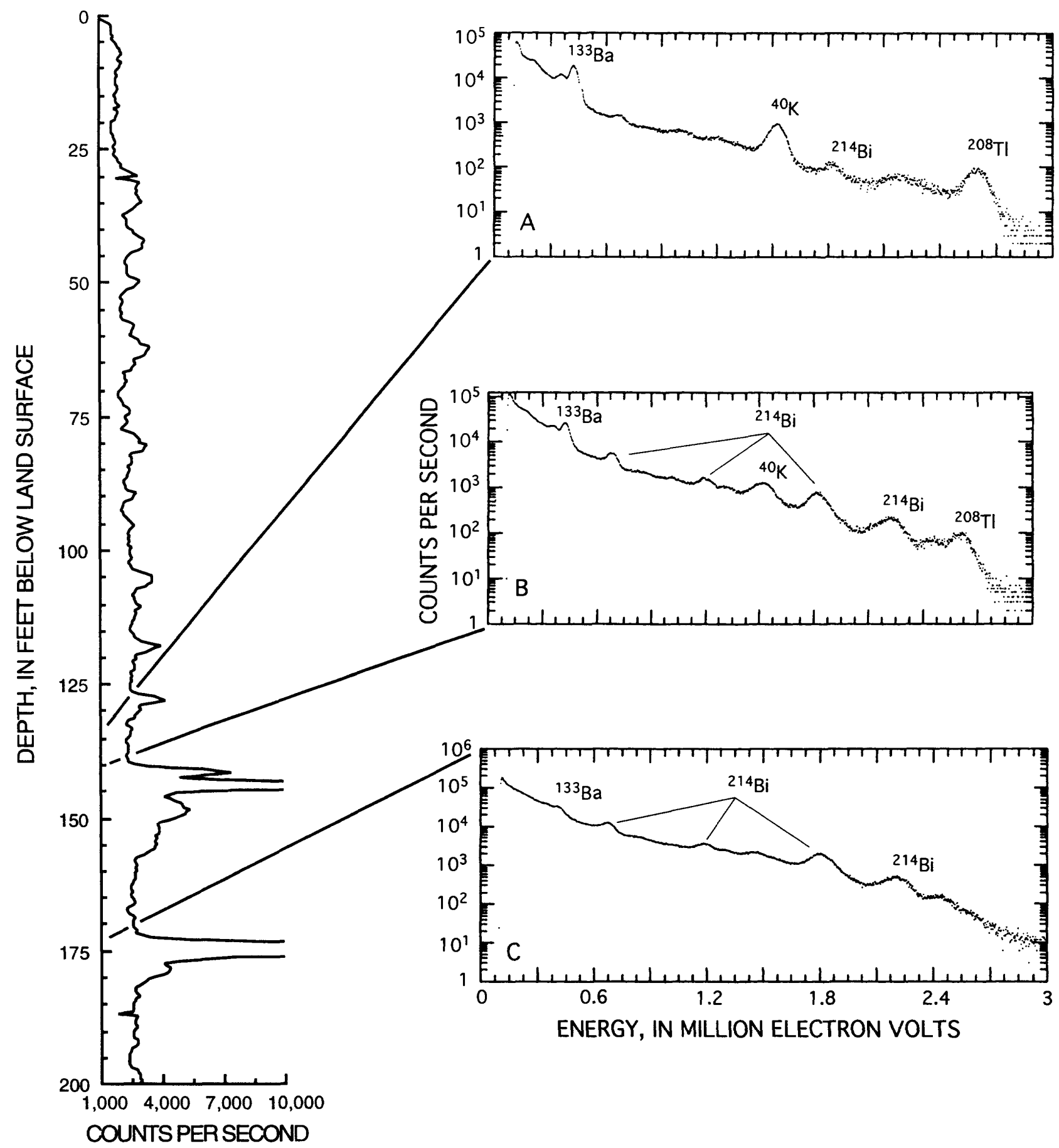

Figure D-2. Gamma log of well 21-159, site 3, Passaic Formation, south-central Newark Basin, New Jersey, and stationary gamma spectra at the following depths, in fect: (A) 133.96, (B) 140.53 , and (C) 172.96 . 


\section{Site 4}

Lithology in the upper half of well 19-251 at site 4 is dominated by a grayish-red purple (5RP4/2) mudstone with occasional interbedded medium-gray (N5) or medium-dark-gray (N4) mudstones (pl. 3). The upper $20 \mathrm{ft}$ of core is a medium to medium-dark gray silty mudstone. A transitional unit at about $180 \mathrm{ft}$ consists of interbedded grayish-red purple mudstone and light-gray (N7) silty mudstone, below which light- to medium-dark-gray silty mudstones predominate to 300 $\mathrm{ft}$ (the bottom of the hole). Bedding in the interbedded grayish-red purple and gray mudstones is consistently massive to convoluted. The medium- to medium-dark-gray mudstones and silty mudstones below $180 \mathrm{ft}$ are commonly massive to convoluted and laminated. Trace fossils are abundant in core recovered from well 19-251. Calcite-filled worm burrows and root casts are rare in the upper $150 \mathrm{ft}$ of the core, but are common below the lithologic transition zone. The core from 184 to $190 \mathrm{ft}$ is intensely bioturbated (pl. 3). Bioturbation, especially by the organism scoyenia, was common on the paleosols forming on the playa mudflats where these sediments were deposited (Olsen, 1980). Calcite-filled mudcracks also are abundant throughout the core. Local zones of brecciation resulting from the high density of mud cracks are found from 86 to $89 \mathrm{ft}$ and from 209 to $226 \mathrm{ft}$. Mudstones grade into light and dark siltstone-mudstone laminae at $30 \mathrm{ft}$ and $192 \mathrm{ft}$. Diagenetic textures (calcite cement) in the light siltstone may have enhanced the contrast between these two lithologies (pl. 3). Local bleached zones are common throughout the core and are associated primarily with high-angle fractures. Bleached zones are dominant above a depth of $200 \mathrm{ft}$, whereas styolites are rare.

Postdepositional calcite is locally common throughout the matrix, mainly as speckling or mottling, void fillings, and in the lower section of the core, as occasional thick calcite veins and fracture fillings. Pyrite speckling is abundant only locally in the medium-dark- to medium-gray mudstones. Clay nodules are common in the grayish-red purple mudstones in the upper $180 \mathrm{ft}$ and rare in the gray mudstones in the lower part of the core. Thin seams of organic plant debris are interbedded in the 247-to-250-ft and 267-to-270-ft intervals. Drilling through these seams and the dark-gray dense mudstone at a depth of $30 \mathrm{ft}$ caused a viscous, oily residue to float to the surface of the drilling fluid. These seams demonstrate the abundance of organic matter associated with these lake and playa deposits in the lower part of the Passaic Formation as previously indicated by Van Houten (1962), Turner-Peterson (1977), and Olsen (1980).

The fracture-density histogram, which begins at a depth of $20 \mathrm{ft}$, shows a highly fractured transition zone from 21 to $55 \mathrm{ft}$ with as many as 22 fractures per 5 - $\mathrm{ft}$ interval and a fissured zone at about $35 \mathrm{ft}(\mathrm{pl}$. 4). From 55 to $175 \mathrm{ft}$, the section is sparsely to moderately fractured, with some unfractured intervals. Three highly fractured sections are present from 175 to $265 \mathrm{ft}$ : the shallowest from 175 to $195 \mathrm{ft}$, with a maximum of 16 fractures per 5-ft interval (depth 185 - 190) and 15 fractures in each of the adjoining 5-ft intervals (180-185 and 190-195 ft); the next from 210 to $235 \mathrm{ft}$, with a maximum of 24 fractures per 5 - $\mathrm{ft}$ interval (depth $210-215 \mathrm{ft}$ ); and the deepest from 250 to $265 \mathrm{ft}$, with a maximum of 14 fractures per 5 - $\mathrm{ft}$ interval (depth $260-265 \mathrm{ft}$ ) (pl. 4). Most of the fractures in these three sections are high-angle open and high-angle sealed. The three highly fractured sections are separated by slightly fractured sections with fewer than 7 fractures per $5-\mathrm{ft}$ interval. 
The BHTV log from well 19-251 confirms that the rocks in the sections from 22 to $55 \mathrm{ft}$ and from 175 to $265 \mathrm{ft}$ are highly fractured (pl. 4). The BHTV log also shows that the number of fractures is smaller in the 55-to-180-ft section than in the section above and below it and that many of the intervals in this section contain no fractures. Vertical and low-angle fractures are both common primarily in the 20-to-55-ft section represented on the BHTV log; the highly fractured section from 180 to $270 \mathrm{ft}$, however, contains many high-angle and near-vertical fractures.

Bedding-plane and low-angle fractures also are apparent, especially at depths of 21 to $60 \mathrm{ft}, 180$ to $200 \mathrm{ft}$, and 250 to $265 \mathrm{ft}$.

The uppermost fractured zone (transition zone, 21-55 ft) coincides with a gray silty mudstone and a grayish-red purple mudstone. The highly fractured interval from 175 to $180 \mathrm{ft}$ corresponds with the lithologic transition zone between interbedded purple and gray mudstone. The series of highly fractured zones below $175 \mathrm{ft}$ coincides with dark gray silty mudstone. The slightly fractured section from 55 to $175 \mathrm{ft}$ coincides with a massive grayish-red purple mudstone (pl. 3).

Fractures in the upper part (21-200 ft) of the core are predominantly open, whereas sealed fractures are abundant below $200 \mathrm{ft}$. Twenty percent of the fractures in the core are sealed; therefore, it is not surprising that this well yields little water.

The depths and the altitudes of the top, bottom, and center of fractures detected with the BHTV and the calculated strike and dip are compiled in table D-4. The BHTV data verify the fracture-density plots, and indicate that most of the low-angle open (possibly water-producing) fractures are in the upper $55 \mathrm{ft}$ of the well.

The HPFM detected natural (unstressed) flow at about the depths of 30,32 , and $51 \mathrm{ft}$. No flow was detected below a depth of $51 \mathrm{ft}$. The fracture-density analysis of the core indicates the presence of a highly fractured interval (depth 25 to $30 \mathrm{ft}$ ) and a fissured zone (at about $35 \mathrm{ft}$ )--the approximate depths at which flow is indicated by the HPFM log. The BHTV also showed a large number of high-angle or nearly vertical fractures and many horizontal fractures in the section from 30 to $50 \mathrm{ft}$ (pl. 4; table D-4). The quantity of non-pumped flow detected by the HPFM was low and is supported by the low yield of this well (discussed further below). Because HPFM-logging of this well was not conducted during pumping, the HPFM data include only natural flow (pl. 4). Large deflections on the single-point-resistance log could result from the presence of either water or fracture-coating minerals whose properties differ from those of the surrounding rock; hence, this $\log$ alone cannot be used to explain the hydrology at this location.

Fracture-surface mineralogy in well $19-251$ is dominated by calcite, limonite, and pyrite to a depth of $105 \mathrm{ft}$; the absence of limonitc below $105 \mathrm{ft}$ indicates that this is the maximum depth of penetration of oxidizing water. Sealed fractures in the upper $100 \mathrm{ft}$ of core are cemented primarily with calcite and pyrite, and trace amounts of clay. Fracturc-surface mineralogy from 105 to $185 \mathrm{ft}$ is dominated by pyrite, calcite, and clay. The highly fractured section from 185 to $240 \mathrm{ft}$ contains fractures cemented with calcite, pyrite, and clay with traces of chlorite. Below this highly fractured section, to a depth of $300 \mathrm{ft}$, fractures are coated by pyritc and calcite. 
Table D-4. Characteristics of fractures identified on borehole televiewer log, and measured flow rates at selected depths, site 4, well 19-251, lower part of the Passaic Formation, south-central Newark Basin, New Jersey

[H, horizontal; V, vertical; N, north; S, south; NW, northwest; NE, northeast; SW, southwest; SE, southeast; NA, not applicable; $\mathrm{O}$, open; SD, sealed; $\mathrm{F}$ indicates natural unstressed flow measured near indicated depth; first number in parentheses is flow rate in gallons per minute, second number is depth of flow measurement in feet below land surface]

\begin{tabular}{|c|c|c|c|c|c|c|}
\hline \multicolumn{3}{|c|}{$\begin{array}{c}\text { Depth of fracture } \\
\text { (feet below land surface) }\end{array}$} & \multicolumn{3}{|c|}{ Fracture orientation } & \multirow{2}{*}{$\begin{array}{l}\text { Condition of } \\
\text { fracture, and } \\
\text { flow rate where } \\
\text { determined }\end{array}$} \\
\hline Top & Center & Bottom & $\begin{array}{r}\mathrm{Di} \\
\text { (degr }\end{array}$ & $\begin{array}{l}\text { ip } \\
\text { rees) }\end{array}$ & $\begin{array}{c}\text { Strike } \\
\text { (degrees) }\end{array}$ & \\
\hline 17.00 & 17.30 & 17.60 & 67 & SE & 79 & O \\
\hline 18.90 & 19.05 & 19.20 & 50 & $\mathrm{~N}$ & 258 & $\mathrm{O}$ \\
\hline 21.00 & 21.00 & 21.00 & $\mathbf{H}$ & & NA & SD \\
\hline 21.00 & 21.45 & 21.90 & 74 & SE & 79 & $\mathrm{O}$ \\
\hline 22.25 & 21.25 & 22.25 & $\mathbf{H}$ & & NA & SD \\
\hline 22.40 & 22.70 & 23.00 & 67 & SE & 51 & 0 \\
\hline 23.40 & 23.40 & 23.40 & $\mathrm{H}$ & & NA & $\mathrm{O}$ \\
\hline 23.50 & 23.75 & 24.00 & 63 & $\mathrm{SE}$ & 51 & SD \\
\hline 27.80 & 30.60 & 33.40 & V & & NA & $\mathrm{O} ; \mathrm{F}(.08,30)$ \\
\hline 32.50 & 32.75 & 33.00 & 63 & $\mathrm{~N}$ & 267 & $\mathrm{SD} ; \mathrm{F}(.12,32)$ \\
\hline 34.00 & 34.20 & 34.40 & 58 & $\mathrm{~N}$ & 260 & SD \\
\hline 34.90 & 35.20 & 35.50 & 67 & SE & 33 & $\mathrm{O}$ \\
\hline 35.00 & 35.50 & 36.00 & 76 & $\mathrm{SE}$ & 42 & $\mathrm{O}$ \\
\hline 38.00 & 38.50 & 39.00 & 76 & $\mathrm{E}$ & 29 & SD \\
\hline 39.00 & 39.00 & 39.00 & $\mathbf{H}$ & & NA & $\mathrm{O}$ \\
\hline 39.20 & 39.65 & 40.10 & 74 & $\mathrm{SE}$ & 33 & $\mathrm{O}$ \\
\hline 41.80 & 41.90 & 42.00 & 39 & SE & 42 & SD \\
\hline 42.60 & 43.10 & 43.60 & 76 & $\mathrm{~N}$ & 261 & SD \\
\hline 43.50 & 43.80 & 44.10 & 67 & $\mathrm{SE}$ & 33 & SD \\
\hline 44.20 & 44.30 & 44.40 & 39 & $\mathrm{SE}$ & 33 & SD \\
\hline 45.30 & 45.70 & 46.10 & 73 & $\mathrm{SE}$ & 33 & $\mathrm{O}$ \\
\hline 46.80 & 46.80 & 46.80 & $\mathrm{H}$ & & NA & SD \\
\hline 47.10 & 47.55 & 48.00 & 74 & $\mathrm{SE}$ & 33 & $\mathrm{O}$ \\
\hline 47.80 & 48.45 & 49.10 & 79 & SW & 123 & $\mathrm{O}$ \\
\hline 51.90 & 51.85 & 51.90 & $\mathrm{H}$ & & NA & $\mathrm{O} ; \mathrm{F}(.08,50)$ \\
\hline
\end{tabular}


Table D-4. Characteristics of fractures identified on borehole televiewer log, and measured flow rates at selected depths, site 4, well 19-251, lower part of the Passaic Formation, south-central Newark Basin, New Jersey--Continued

\begin{tabular}{|c|c|c|c|c|c|c|}
\hline \multicolumn{3}{|c|}{$\begin{array}{c}\text { Depth of fracture } \\
\text { (feet below land surface) }\end{array}$} & \multicolumn{3}{|c|}{ Fracture orientation } & \multirow{2}{*}{$\begin{array}{c}\text { Condition of } \\
\text { fracture, and } \\
\text { flow rate where } \\
\text { determined }\end{array}$} \\
\hline Top & Center & Bottom & $\begin{array}{r}\mathrm{Di} \\
(\operatorname{deg} I\end{array}$ & ip & $\begin{array}{c}\text { Strike } \\
\text { (degrees) }\end{array}$ & \\
\hline 55.90 & 56.20 & 56.50 & 67 & SE & 42 & 0 \\
\hline 57.80 & 57.80 & 57.80 & $\mathrm{H}$ & & NA & SD \\
\hline 58.60 & 58.60 & 58.60 & $\mathbf{H}$ & & NA & SD \\
\hline 59.40 & 59.80 & 60.20 & 73 & SE & 33 & SD \\
\hline 65.00 & 65.40 & 65.80 & 73 & SE & 42 & 0 \\
\hline 67.00 & 67.00 & 67.00 & $\mathrm{H}$ & & NA & 0 \\
\hline 78.00 & 78.00 & 78.00 & $\mathrm{H}$ & & NA & SD \\
\hline 78.80 & 79.20 & 79.60 & 73 & SE & 33 & $\mathrm{O}$ \\
\hline 88.60 & 89.10 & 89.60 & 76 & $\mathrm{E}$ & 24 & O \\
\hline 90.80 & $91.20^{\circ}$ & 91.60 & 73 & SE & 33 & O \\
\hline 96.25 & 96.25 & 96.25 & $\mathrm{H}$ & & NA & SD \\
\hline 97.60 & 97.90 & 98.20 & 67 & $\mathrm{~N}$ & 276 & SD \\
\hline 103.40 & 103.70 & 104.00 & 67 & $\mathrm{~N}$ & 267 & $\mathrm{SD}$ \\
\hline 104.98 & 104.98 & 104.98 & $\mathrm{H}$ & & NA & SD \\
\hline 141.00 & 141.30 & 141.60 & 67 & SE & 33 & SD \\
\hline 141.40 & 141.80 & 142.20 & 73 & $\mathrm{SE}$ & 33 & SD \\
\hline 141.70 & 142.15 & 142.60 & 74 & SE & 33 & O \\
\hline 142.20 & 142.35 & 142.50 & 50 & SE & 33 & SD \\
\hline 146.40 & 146.60 & 146.80 & 58 & $\mathrm{~N}$ & 260 & SD \\
\hline 147.60 & 148.10 & 148.60 & 76 & SE & 42 & SD \\
\hline 158.20 & 158.40 & 158.60 & 58 & $\mathrm{~N}$ & 259 & SD \\
\hline 172.30 & 172.80 & 173.30 & 76 & SE & 79 & SD \\
\hline 173.20 & 175.20 & 177.20 & 86 & $S$ & 80 & 0 \\
\hline 179.10 & 179.40 & 179.70 & 67 & NW & 261 & 0 \\
\hline 182.40 & 183.15 & 183.90 & 81 & SE & 51 & O \\
\hline 185.00 & 185.50 & 186.00 & 76 & SE & 60 & \\
\hline 187.20 & 187.20 & 187.20 & $\mathrm{H}$ & & NA & SD \\
\hline 188.00 & 188.00 & 188.00 & $\mathrm{H}$ & & NA & SD \\
\hline 189.60 & 190.10 & 190.60 & 76 & NW & 261 & O \\
\hline 190.80 & 190.80 & 190.80 & $\mathbf{H}$ & & NA & SD \\
\hline
\end{tabular}


Table D-4. Characteristics of fractures identified on borehole televiewer log, and measured flow rates at selected depths, site 4, well 19-251, lower part of the Passaic Formation, south-central Newark Basin, New Jersey--Continued

\begin{tabular}{|c|c|c|c|c|c|c|}
\hline \multicolumn{3}{|c|}{$\begin{array}{c}\text { Depth of fracture } \\
\text { (feet below land surface) }\end{array}$} & \multicolumn{3}{|c|}{ Fracture orientation } & \multirow{2}{*}{$\begin{array}{l}\text { Condition of } \\
\text { fracture, and } \\
\text { flow rate where } \\
\text { determined }\end{array}$} \\
\hline Top & Center & Bottom & $\begin{array}{r}\mathrm{Di} \\
(\mathrm{deg} r\end{array}$ & $\begin{array}{l}\mathrm{p} \\
\mathrm{ees})\end{array}$ & $\begin{array}{c}\text { Strike } \\
\text { (degrees) }\end{array}$ & \\
\hline 192.00 & 192.50 & 193.00 & 76 & SE & 33 & SD \\
\hline 195.00 & 195.65 & 196.30 & 79 & SE & 33 & 0 \\
\hline 197.50 & 197.95 & 198.40 & $\mathrm{~V}$ & & NA & SD \\
\hline 199.20 & 199.65 & 200.10 & 74 & SE & 33 & O \\
\hline 201.40 & 201.70 & 202.00 & 67 & $\mathbf{N}$ & 267 & 0 \\
\hline 201.50 & 201.50 & 201.50 & $\mathrm{H}$ & & NA & O \\
\hline 203.40 & 204.50 & 205.60 & 84 & $S$ & 96 & SD \\
\hline 205.40 & 205.70 & 206.00 & 67 & S & 96 & O \\
\hline 206.40 & 206.90 & 207.40 & 76 & S & 96 & O \\
\hline 208.60 & 208.60 & 208.60 & $\mathrm{H}$ & & NA & SD \\
\hline 211.00 & 211.00 & 211.00 & $\mathrm{H}$ & & NA & O \\
\hline 212.00 & 212.00 & 212.00 & $\mathrm{H}$ & & NA & O \\
\hline 212.80 & 213.10 & 213.40 & 67 & $\mathrm{E}$ & 348 & O \\
\hline 214.00 & 214.30 & 214.60 & 67 & W & 177 & O \\
\hline 215.60 & 215.60 & 215.60 & $\mathrm{H}$ & & NA & $\mathrm{O}$ \\
\hline 216.70 & 216.70 & 216.70 & $\mathrm{H}$ & & NA & 0 \\
\hline 217.00 & 217.00 & 217.00 & $\mathrm{H}$ & & NA & O \\
\hline 217.60 & 218.30 & 219.00 & 80 & W & 204 & 0 \\
\hline 219.60 & 219.60 & 219.60 & $\mathrm{H}$ & & NA & 0 \\
\hline 220.70 & 220.70 & 220.70 & $\mathrm{H}$ & & NA & 0 \\
\hline 223.60 & 223.90 & 224.20 & 67 & $S$ & 96 & $\mathrm{O}$ \\
\hline 224.20 & 224.30 & 224.40 & 39 & $S$ & 96 & O \\
\hline 224.40 & 224.60 & 224.80 & 58 & $S$ & 96 & 0 \\
\hline 225.40 & 225.90 & 226.40 & 76 & E & 24 & O \\
\hline 226.60 & 227.10 & 227.60 & 76 & $\mathrm{E}$ & 24 & $\mathrm{O}$ \\
\hline 226.80 & 227.20 & 227.60 & 73 & E & 24 & O \\
\hline 227.00 & 227.40 & 227.80 & 73 & E & 24 & 0 \\
\hline 229.00 & 229.60 & 230.20 & 78 & $\mathrm{SE}$ & 51 & 0 \\
\hline 231.00 & 231.30 & 231.60 & 67 & $\mathrm{SE}$ & 51 & SD \\
\hline 236.10 & 236.55 & 237.00 & 74 & $\mathbf{N}$ & 259 & SD \\
\hline
\end{tabular}


Table D-4. Characteristics of fractures identified on borehole televiewer log, and measured flow rates at selected depths, site 4, well 19-251, lower part of the Passaic Formation, south-central Newark Basin, New Jersey--Continued

\begin{tabular}{|c|c|c|c|c|c|}
\hline \multicolumn{3}{|c|}{$\begin{array}{c}\text { Depth of fracture } \\
\text { (feet below land surface) }\end{array}$} & \multicolumn{2}{|c|}{ Fracture orientation } & \multirow{2}{*}{$\begin{array}{l}\text { Condition of } \\
\text { fracture, and } \\
\text { flow rate where } \\
\text { determined }\end{array}$} \\
\hline Top & Center & Bottom & $\begin{array}{c}\text { Dip } \\
\text { (degrees) }\end{array}$ & $\begin{array}{c}\text { Strike } \\
\text { (degrees) }\end{array}$ & \\
\hline 244.00 & 244.00 & 244.00 & $\mathrm{H}$ & NA & SD \\
\hline 247.00 & 247.35 & 247.70 & $70 \mathrm{SE}$ & 42 & SD \\
\hline 252.40 & 252.90 & 253.40 & $76 \mathrm{SE}$ & 42 & SD \\
\hline 257.00 & 257.30 & 257.60 & $67 \mathrm{SE}$ & 42 & SD \\
\hline 257.50 & 257.90 & 258.30 & $73 \mathrm{SE}$ & 42 & SD \\
\hline
\end{tabular}


Two intervals exhibit anomalously high radioactivity (greater than $400 \mathrm{cps} ; \mathrm{pl.} 3$ ): one in the depth interval from 30 to $35 \mathrm{ft}$ and the other in the depth interval from 190 to $195 \mathrm{ft}$. Each gamma peak is associated with a zone of alternating light-and-dark laminated interbedded siltstone and mudstone near a dense, medium-dark-gray, massive mudstone (pl. 3). Five minor radioactive zones (greater than $200 \mathrm{cps}$ ) are centered at $72,173,213,228$, and $249 \mathrm{ft}$.

Stationary gamma spectra were used to identify the radionuclides in the two major and three of the five minor peaks on the gamma $\log$ (fig. D-3). Total integrated counts for the gamma spectra at $33.18 \mathrm{ft}$ were greatest (table D-2). The ${ }^{238} \mathrm{U}$ series progeny probably account for the anomalously high counts. All the gamma spectra show prominent peaks of ${ }^{40} \mathrm{~K}$ and ${ }^{208} \mathrm{Tl}$, but only the two major gamma peaks show gamma spectra with significant ${ }^{214} \mathrm{Bi}$ peaks (fig. D-3).

Yield from well 19-251 was poor. During sampling, $0.5 \mathrm{gal} / \mathrm{min}$ was pumped from the well with a drawdown of $120 \mathrm{ft}$. During well development, a maximum yield of $1 \mathrm{gal} / \mathrm{min}$ was maintained for about 1 hour, with a drawdown of about $200 \mathrm{ft}$. Minimal surficial weathering and clogging of fractures by plastic clay at shallow depths limit water circulation in the bedrock. The absence of fracturing in the thick section of massive grayish-red purple mudstone below $55 \mathrm{ft}$ effectively limits the circulation of water below this depth. The extensively fractured zone below the grayish-red purple mudstone is dominated by sealed fractures, confirming that little water circulates at these depths. If one accepts the hypothesis of Michalski (1990) that horizontal fractures are the major conduits of flow in rocks of the lower part of the Passaic Formation, the general dominance of high-angle fractures in strata intercepted by this well may be a contributing factor to the low yield.

The dominant rock type in well 19-250 is a medium-dark (N4) to light-gray (N6) mudstone or silty mudstone with minor amounts of calcareous light-gray (N8) mudstone. Other important rock types are brownish (5YR4/1) and brownish-gray (5YR6/1) mudstones. In general, bedding is massive in the medium-dark-gray mudstones and silty mudstones, but is massive to laminar and convoluted in the lighter gray mudstones and brown and brownish-gray mudstones. Calcite- and pyrite-filled root casts, worm burrows, and mudcracks are abundant in the lower half (below 215 $\mathrm{ft}$ ) of the core, but rare in the upper half. The silty mudstones and mudstones from 263 to $298 \mathrm{ft}$ and 326 to $363 \mathrm{ft}$ are intensely bioturbated (pl. 3).

Secondary bleached zones typically have a greenish hue, are abundant above a depth of 250 $\mathrm{ft}$, and are associated with mudstones. Styolites are rare but, where present, are found in the upper half of the core in silty mudstone. Thin beds of alternating light and dark laminae composed of thin intercalated calcareous mudstones and sections of silty mudstones are common in silty calcareous mudstones throughout the core.

Calcite is abundant in the mudstone matrix and is present mostly as speckling, void fillings, and some thick veins. Pyrite is common in places in the light- to medium-gray mudstones, as speckling and void fillings. From 124 to $128 \mathrm{ft}$, pyrite is present as large, euhedral grains. Pyrite is absent from the massive mudstone (132-213 ft). Clay nodules are scattered throughout the core, especially in mudstones. 


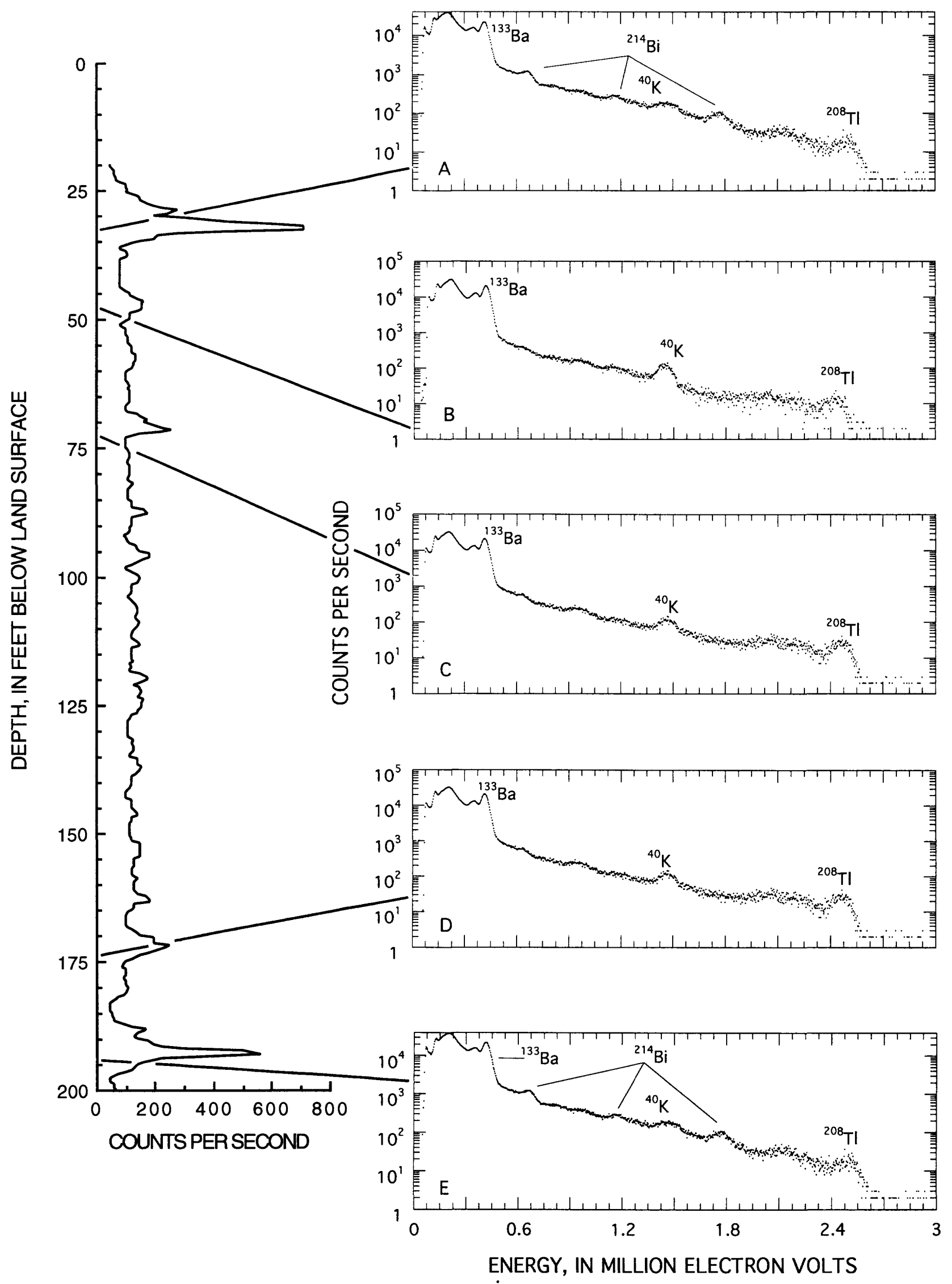

Figure D-3. Gamma log of well 19-251, site 4, Passaic Formation, south-central Newark Basin, New Jersey, and stationary gamma spectra at the following depths, in feet: (A) 33.18, (B) 48.0. (C) 72.81 , (D) 172.98 , and (E) 193.3. 
The fracture-density histogram of well 19-250, which begins at a depth of $10 \mathrm{ft}(\mathrm{pl} .4)$, shows a highly fractured section (transition zone) immediately below the regolith from 10 to $30 \mathrm{ft}$ below land surface. A fissured zone at about $20 \mathrm{ft}$ may conduct significant quantities of water. The dominant fracture type in the transition zone is low-angle open. Below the transition zone, the core is moderately fractured to $175 \mathrm{ft}$, with some highly fractured 5-ft intervals; the core is moderately to highly fractured from 175 to $240 \mathrm{ft}$. Below $240 \mathrm{ft}$, the core is moderately fractured with only two $5-\mathrm{ft}$ intervals (350-355 $\mathrm{ft}$ and $385-390 \mathrm{ft}$ ) containing more than 10 fractures. Sealed fractures are common below $325 \mathrm{ft}$. Sealed fractures in the upper $215 \mathrm{ft}$ generally are cemented with calcite and pyrite, and minor amounts of limonite, chlorite, and clay. Fractures below $325 \mathrm{ft}$ are sealed with calcite, pyrite, clay, and traces of chlorite. A greater percentage of the low-angle fractures are open in this core than in the core from well 19-251.

The BHTV log illustrates the fractures in the borehole and confirms the data presented in the fracture-density histogram. The fissured zone at about $20 \mathrm{ft}$ appears on the BHTV log as several bedding-plane fractures and a low-angle fracture. The BHTV log shows few fractures from 70 to $85 \mathrm{ft}$ and below $275 \mathrm{ft}$ (table D-5).

The fractured rocks penetrated by well 19-250 illustrate the relation among fracture density, spontaneous potential, and resistance. Most of the water in well 19-250 is obtained from the fractures in the intervals 10 to $15 \mathrm{ft}, 15$ to $20 \mathrm{ft}, 100$ to $105 \mathrm{ft}, 120$ to 125 , and 125 to $130 \mathrm{ft}$. Wide horizontal fractures found at 102 and $123 \mathrm{ft}$ (pl. 4, table 7) are likely to transmit water. This conclusion is supported by the flow data collected by using the HPFM (pl. 4; fig. 9). A positive response on the spontaneous-potential log and a decrease in resistance on the single-point-resistance $\log$ at or adjacent to the 15-to-20-ft, the 95-to-100-ft, and the 115-to-120-ft intervals also indicates the possible presence of water-bearing fractures. The highly fractured section from 21 to $50 \mathrm{ft}$ represented on the BHTV log coincides with the zone of upward flow represented in the HPFM data collected during pumping (pl. 4), indicating that the fractures in this section are likely interconnected and probably contribute to flow at about $18.5-20.5 \mathrm{ft}$ in the fissured zone. Water also flows in the highly fractured section from 36 to $62 \mathrm{ft}$, most likely at the large fracture zone at $62 \mathrm{ft}$. The section from 10 to $20 \mathrm{ft}$ with the fissured zone also has an associated large peak on the gamma $\log$ (fig. 9). Large gamma peaks are also present at depths of 102 and $125 \mathrm{ft}$.

The moderately to highly fractured section from 175 to $240 \mathrm{ft}$ is represented by decreases in resistance in individual fractured zones; it is believed to contain little or no water because no flow was detected with the HPFM, and because it is separated from the water-bearing interval at $125 \mathrm{ft}$ by nearly $50 \mathrm{ft}$ of sparsely fractured strata. The responses of the resistance $\log$ and the spontaneous-potential log were greater below $240 \mathrm{ft}$ than in the shallower section from 120 to $240 \mathrm{ft}$. Because few, if any, water-bearing fractures are found at these depths, this response may be the result of lithologic variability.

Fracture-surface mineralogy throughout the core is dominated by calcite and pyrite. Limonite is present only to a depth of $35 \mathrm{ft}$, marking the extent of the penetration of the oxidizing water. The absence of limonite in fractures below a depth of $35 \mathrm{ft}(\mathrm{pl} .4)$ corresponds to the presence of oxygen-poor water in this borehole (app. 3). Calcite, where present in the fractures or rock matrix in the highly fractured section from 10 to $30 \mathrm{ft}$, is etched and pitted. Chlorite is present as fracture fill in the section from 185 to $290 \mathrm{ft}$ and coexists with calcite and pyrite. Clay is present in trace quantities in fractures throughout the core. 
Table D-5. Characteristics of fractures identified on borehole televiewer log, and measured flow rates at selected depths, site 4, well 19-250, lower part of the Passaic Formation, south-central Newark Basin, New Jersey

[H, horizontal; V, vertical; N, north; S, south; NW, northwest; NE, northeast; SW, southwest; SE, southeast; NA, not applicable; $\mathrm{O}$, open; SD, sealed; $\mathrm{F}$ indicates natural unstressed flow measured; near indicated depth; first number in parentheses is flow rate in gallons per minute, second number is depth of flow measurement in feet below land surface]

\begin{tabular}{|c|c|c|c|c|c|c|}
\hline \multicolumn{3}{|c|}{$\begin{array}{c}\text { Depth of fracture } \\
\text { (feet below land surface) }\end{array}$} & \multicolumn{3}{|c|}{ Fracture orientation } & \multirow{2}{*}{$\begin{array}{l}\text { Condition of } \\
\text { fracture, and flow } \\
\text { rate where } \\
\text { determined }\end{array}$} \\
\hline Top & Center & Bottom & $\begin{array}{r}D \\
\text { (deg }\end{array}$ & $\begin{array}{l}\text { ip } \\
\text { rees) }\end{array}$ & $\begin{array}{c}\text { Strike } \\
\text { (degrees) }\end{array}$ & \\
\hline 21.40 & 21.50 & 21.60 & 39 & $\mathrm{NE}$ & 321 & $\mathrm{O}(<0.08,20)$ \\
\hline 22.60 & 22.80 & 23.00 & 58 & $\mathrm{~N}$ & 294 & $\mathrm{O}$ \\
\hline 23.00 & 23.50 & 24.00 & 76 & SE & 42 & $\mathrm{O}$ \\
\hline 23.60 & 23.70 & 23.80 & 39 & $\mathrm{NE}$ & 321 & $\mathrm{O}$ \\
\hline 24.00 & 24.63 & 25.25 & 79 & $\mathrm{E}$ & 24 & $\mathrm{O}$ \\
\hline 24.20 & 24.80 & 25.40 & 78 & $\mathrm{E}$ & 24 & 0 \\
\hline 26.00 & 26.33 & 26.65 & 69 & $\mathrm{~N}$ & 285 & $\mathrm{O}$ \\
\hline 26.75 & 27.27 & 27.80 & 77 & SE & 33 & $\mathrm{O}$ \\
\hline 27.70 & 28.00 & 28.30 & 67 & $S$ & 60 & $\mathrm{O}$ \\
\hline 28.75 & 28.75 & 28.75 & $\mathrm{H}$ & & NA & SD \\
\hline 28.00 & 28.70 & 29.40 & 80 & $\mathrm{~S}$ & 87 & $\mathrm{O}$ \\
\hline 29.05 & 29.05 & 29.05 & $\mathrm{H}$ & & NA & 0 \\
\hline 36.10 & 36.61 & 37.12 & 76 & SE & 42 & $\mathrm{O}$ \\
\hline 39.20 & 39.60 & 40.00 & 73 & $S$ & 51 & $\mathrm{O} ; \mathrm{F}(.74,38)$ \\
\hline 39.42 & 39.81 & 40.20 & 72 & $\mathrm{~S}$ & 51 & SD \\
\hline 40.40 & 40.50 & 40.60 & 39 & $\mathrm{~N}$ & 258 & SD \\
\hline 41.60 & 41.60 & 41.60 & $\mathrm{H}$ & & NA & SD \\
\hline 42.25 & 42.75 & 43.25 & 76 & $\mathrm{E}$ & 348 & 0 \\
\hline 42.70 & 43.20 & 43.70 & 76 & $\mathrm{~S}$ & 69 & SD \\
\hline 45.00 & 47.00 & 49.00 & V & & NA & $O ; F(.71,45)$ \\
\hline 53.10 & 53.47 & 53.85 & 72 & $\mathrm{~S}$ & 51 & SD; F $(.77,50)$ \\
\hline 54.50 & 54.50 & 54.50 & $\mathrm{H}$ & & NA & $\mathrm{SD} ; \mathrm{F}(.72,55)$ \\
\hline 58.10 & 58.45 & 58.80 & 70 & $\mathrm{~S}$ & 51 & $\mathrm{O} ; \mathrm{F}(.78,60)$ \\
\hline 64.00 & 64.05 & 64.10 & 22 & SW & 132 & 0 \\
\hline 64.10 & 65.05 & 66.00 & 83 & SW & 114 & SD \\
\hline
\end{tabular}


Table D-5. Characteristics of fractures identified on borehole televiewer log, and measured flow rates at selected depths, site 4, well 19-250, lower part of the Passaic Formation, south-central Newark Basin, New Jersey--Continued

\begin{tabular}{|c|c|c|c|c|c|c|}
\hline \multicolumn{3}{|c|}{$\begin{array}{c}\text { Depth of fracture } \\
\text { (feet below land surface) }\end{array}$} & \multicolumn{3}{|c|}{ Fracture orientation } & \multirow{2}{*}{$\begin{array}{l}\text { Condition of } \\
\text { fracture, and flow } \\
\text { rate where } \\
\text { determined }\end{array}$} \\
\hline Top & Center & Bottom & $\begin{array}{r}D \\
\text { (deg }\end{array}$ & $\begin{array}{l}\text { ip } \\
\text { rees) }\end{array}$ & $\begin{array}{c}\text { Strike } \\
\text { (degrees) }\end{array}$ & \\
\hline 66.10 & 66.95 & 67.80 & 82 & $S$ & 96 & SD \\
\hline 68.00 & 68.00 & 68.00 & $\mathrm{H}$ & & NA & SD \\
\hline 68.95 & 68.97 & 69.00 & $\mathrm{H}$ & & NA & SD \\
\hline 69.00 & 69.00 & 69.00 & $\mathrm{H}$ & & NA & SD \\
\hline 73.00 & 73.50 & 74.00 & 76 & $S$ & 78 & SD \\
\hline 93.80 & 93.85 & 93.90 & 22 & $\mathbf{N}$ & 258 & SD \\
\hline 95.00 & 95.30 & 95.60 & 67 & $\mathrm{~S}$ & 51 & SD \\
\hline 102.20 & 102.25 & 102.30 & 22 & $\mathbf{N}$ & 258 & $\mathrm{SD} ; \mathrm{F}(.76,100)$ \\
\hline 105.00 & 105.20 & 105.40 & 58 & SE & 33 & SD \\
\hline 107.50 & 108.35 & 109.20 & 82 & SE & 24 & SD \\
\hline 113.00 & 113.40 & 113.80 & 73 & SE & 42 & SD \\
\hline 122.40 & 122.40 & 122.40 & $\mathbf{H}$ & & NA & $\mathrm{SD} ; \mathrm{F}(.68,120)$ \\
\hline 122.80 & 122.80 & 122.80 & $\mathbf{H}$ & & NA & SD \\
\hline 123.40 & 123.40 & 123.40 & $\mathrm{H}$ & & NA & $\mathrm{O} ; \mathrm{F}(.62,125)$ \\
\hline 126.90 & 127.00 & 127.10 & 39 & $\mathbf{N}$ & 258 & SD \\
\hline 134.00 & 134.10 & 134.20 & 39 & $\mathbf{N}$ & 258 & SD \\
\hline 135.40 & 135.90 & 136.40 & 76 & SE & 42 & SD \\
\hline 137.60 & 137.60 & 137.60 & H & & NA & SD \\
\hline 137.70 & 137.95 & 138.20 & 63 & $\mathrm{SE}$ & 42 & SD \\
\hline 140.00 & 140.32 & 140.65 & 69 & $\mathrm{SE}$ & 42 & 0 \\
\hline 144.80 & 145.05 & 145.30 & 63 & SE & 33 & SD \\
\hline 146.65 & 147.90 & 149.16 & 84 & SW & 141 & SD \\
\hline 151.20 & 151.20 & 151.20 & $\mathrm{H}$ & & NA & SD \\
\hline 153.60 & 153.60 & 153.60 & H & & NA & SD \\
\hline 154.20 & 154.20 & 154.20 & $\mathrm{H}$ & & NA & SD \\
\hline 157.20 & 157.55 & 157.90 & 70 & SE & 33 & SD \\
\hline 162.10 & 162.17 & 162.23 & 27 & $\mathrm{~N}$ & 261 & SD \\
\hline 164.03 & 164.26 & 164.50 & 62 & $\mathbf{N}$ & 294 & SD \\
\hline 164.65 & 164.65 & 164.65 & $\mathrm{H}$ & & NA & SD \\
\hline 168.85 & 168.90 & 168.95 & 22 & NW & 258 & 0 \\
\hline
\end{tabular}


Table D-5. Characteristics of fractures identified on borehole televiewer log, and measured flow rates at selected depths, site 4, well 19-250, lower part of the Passaic Formation, south-central Newark Basin, New Jersey--Continued

\begin{tabular}{|c|c|c|c|c|c|c|}
\hline \multicolumn{3}{|c|}{$\begin{array}{c}\text { Depth of fracture } \\
\text { (feet below land surface) }\end{array}$} & \multicolumn{3}{|c|}{ Fracture orientation } & \multirow{2}{*}{$\begin{array}{l}\text { Condition of } \\
\text { fracture, and flow } \\
\text { rate where } \\
\text { determined }\end{array}$} \\
\hline Top & Center & Bottom & $\begin{array}{r}D \\
\text { (deg }\end{array}$ & $\begin{array}{l}\text { ip } \\
\text { rees) }\end{array}$ & $\begin{array}{c}\text { Strike } \\
\text { (degrees) }\end{array}$ & \\
\hline 171.60 & 172.05 & 172.50 & 74 & $\mathrm{SE}$ & 42 & SD \\
\hline 173.20 & 173.50 & 173.80 & 67 & $S$ & 51 & SD \\
\hline 176.30 & 176.55 & 176.80 & 63 & $\mathrm{SE}$ & 42 & SD \\
\hline 180.20 & 180.50 & 180.80 & 67 & $\mathrm{SE}$ & 42 & SD \\
\hline 183.10 & 183.40 & 183.70 & 67 & $\mathrm{SE}$ & 42 & SD \\
\hline 183.40 & 183.52 & 183.65 & 45 & $S$ & 60 & SD \\
\hline 184.20 & 184.70 & 185.20 & 76 & $\mathrm{~S}$ & 96 & SD \\
\hline 185.25 & 185.57 & 185.90 & 69 & SE & 42 & SD \\
\hline 187.00 & 188.60 & 190.20 & 86 & SW & 123 & SD \\
\hline 188.00 & 188.30 & 188.60 & 67 & SW & 123 & SD \\
\hline 189.00 & 189.00 & 189.00 & $\mathrm{H}$ & & NA & SD \\
\hline 190.60 & 191.00 & 191.40 & 73 & $\mathrm{SE}$ & 42 & O \\
\hline 193.60 & 193.85 & 194.10 & 63 & $S$ & 51 & 0 \\
\hline 194.70 & 195.00 & 195.30 & 67 & $\mathrm{SE}$ & 42 & O \\
\hline 198.20 & 198.30 & 198.40 & 39 & $\mathrm{SE}$ & 42 & SD \\
\hline 198.30 & 198.65 & 199.00 & 70 & $\mathrm{SE}$ & 42 & 0 \\
\hline 198.60 & 199.10 & 199.60 & 76 & SE & 42 & $\mathrm{O} ; \mathrm{F}(.02,200)$ \\
\hline 203.60 & 203.85 & 204.10 & 63 & $\mathrm{SE}$ & 42 & SD \\
\hline 204.20 & 204.55 & 204.90 & 70 & SE & 33 & 0 \\
\hline 206.40 & 206.75 & 207.10 & 70 & SE & 42 & 0 \\
\hline 207.90 & 208.18 & 208.45 & 66 & $S$ & 51 & 0 \\
\hline 209.00 & 209.50 & 210.00 & 76 & SW & 132 & SD \\
\hline 209.80 & 210.10 & 210.40 & 67 & $\mathbf{S}$ & 114 & SD \\
\hline 210.25 & 210.53 & 210.80 & 66 & SE & 42 & 0 \\
\hline 211.40 & 211.60 & 211.80 & 58 & $S$ & 51 & 0 \\
\hline 212.20 & 212.50 & 212.80 & 67 & $S$ & 51 & 0 \\
\hline 215.50 & 215.80 & 216.10 & 67 & $\mathrm{~S}$ & 60 & O \\
\hline 216.00 & 216.30 & 216.60 & 67 & $\mathrm{~S}$ & 51 & O \\
\hline 217.70 & 217.95 & 218.20 & 63 & $\mathbf{S}$ & 51 & O \\
\hline 219.00 & 219.40 & 219.80 & 73 & $\mathrm{~S}$ & 60 & 0 \\
\hline
\end{tabular}


Table D-5. Characteristics of fractures identified on borehole televiewer log, and measured flow rates at selected depths, site 4, well 19-250, lower part of the Passaic Formation, south-central Newark Basin, New Jersey--Continued

\begin{tabular}{|c|c|c|c|c|c|c|}
\hline \multicolumn{3}{|c|}{$\begin{array}{c}\text { Depth of fracture } \\
\text { (feet below land surface) }\end{array}$} & \multicolumn{3}{|c|}{ Fracture orientation } & \multirow{2}{*}{$\begin{array}{l}\text { Condition of } \\
\text { fracture, and flow } \\
\text { rate where } \\
\text { determined }\end{array}$} \\
\hline Top & Center & Bottom & $\begin{array}{r}D \\
\text { (degr }\end{array}$ & ip & $\begin{array}{c}\text { Strike } \\
\text { (degrees) }\end{array}$ & \\
\hline 221.00 & 221.40 & 221.80 & 73 & $\mathrm{SE}$ & 42 & $\mathrm{O}$ \\
\hline 222.60 & 222.75 & 222.90 & 50 & $S$ & 51 & $\mathrm{SD}$ \\
\hline 225.60 & 225.88 & 226.15 & 66 & SE & 42 & SD \\
\hline 225.85 & 226.16 & 226.46 & 68 & SE & 42 & $\mathrm{O}$ \\
\hline 225.90 & 226.20 & 226.50 & 67 & SE & 42 & $\mathrm{O}$ \\
\hline 226.30 & 226.60 & 226.90 & 67 & SE & 42 & $\mathrm{O}$ \\
\hline 226.70 & 227.05 & 227.40 & 70 & $\mathrm{SE}$ & 42 & $\mathrm{O}$ \\
\hline 227.20 & 227.65 & 228.10 & 74 & SE & 42 & $\mathrm{O}$ \\
\hline 227.60 & 228.25 & 228.90 & 79 & SE & 42 & $\mathrm{O}$ \\
\hline 229.40 & 229.68 & 229.95 & 66 & $S$ & 51 & $\mathrm{O}$ \\
\hline 230.00 & 230.40 & 230.80 & 73 & $S$ & 60 & O \\
\hline 231.00 & 231.98 & 233.95 & V & & NA & $\mathrm{O}$ \\
\hline 234.20 & 234.35 & 234.50 & 50 & $S$ & 51 & $\mathrm{O}$ \\
\hline 234.70 & 234.95 & 235.20 & 63 & $S$ & 51 & 0 \\
\hline 235.40 & 235.65 & 235.90 & 63 & SE & 42 & $\mathrm{O}$ \\
\hline 235.80 & 236.05 & 236.30 & 63 & SE & 42 & $\mathrm{O}$ \\
\hline 236.60 & 236.85 & 237.10 & 63 & $S$ & 60 & O \\
\hline 236.70 & 237.10 & 237.50 & 73 & SW & 132 & SD \\
\hline 240.80 & 241.20 & 241.60 & 73 & $\mathrm{~S}$ & 78 & 0 \\
\hline 244.43 & 244.87 & 245.30 & 74 & $S$ & 51 & SD \\
\hline 244.80 & 244.90 & 245.00 & 39 & $S$ & 60 & SD \\
\hline 250.10 & 250.43 & 250.75 & 69 & $S$ & 78 & $\mathrm{O} ; \mathrm{F}(.03,250)$ \\
\hline 251.00 & 251.45 & 251.90 & 74 & $S$ & 60 & SD \\
\hline 253.15 & 253.38 & 253.60 & 61 & $S$ & 60 & SD \\
\hline 255.43 & 255.66 & 255.90 & 62 & $\mathrm{~S}$ & 60 & o \\
\hline 256.90 & 257.15 & 257.40 & 63 & $S$ & 60 & $\mathrm{O}$ \\
\hline 262.50 & 262.65 & 262.80 & 50 & $\mathrm{SE}$ & 42 & SD \\
\hline 263.00 & 263.00 & 263.00 & $\mathrm{H}$ & & NA & 0 \\
\hline 265.50 & 265.90 & 266.30 & 73 & SE & 42 & SD \\
\hline 267.10 & 267.43 & 267.75 & 69 & $\mathrm{~N}$ & 285 & SD \\
\hline
\end{tabular}


Table D-5. Characteristics of fractures identified on borehole televiewer log, and measured flow rates at selected depths, site 4, well 19-250, lower part of the Passaic Formation, south-central Newark Basin, New Jersey--Continued

\begin{tabular}{|c|c|c|c|c|c|c|}
\hline \multicolumn{3}{|c|}{$\begin{array}{c}\text { Depth of fracture } \\
\text { (feet below land surface) }\end{array}$} & \multicolumn{3}{|c|}{ Fracture orientation } & \multirow{2}{*}{$\begin{array}{l}\text { Condition of } \\
\text { fracture, and flow } \\
\text { rate where } \\
\text { determined }\end{array}$} \\
\hline Top & Center & Bottom & $\begin{array}{r}\mathrm{D} \\
(\mathrm{deg}\end{array}$ & $\begin{array}{l}\text { ip } \\
\text { ees) }\end{array}$ & $\begin{array}{c}\text { Strike } \\
\text { (degrees) }\end{array}$ & \\
\hline 279.05 & 279.52 & 280.00 & 75 & SE & 42 & $\mathrm{O}$ \\
\hline 280.00 & 280.30 & 280.60 & 67 & S & 51 & SD \\
\hline 283.40 & 283.75 & 284.10 & 70 & SE & 42 & $\mathrm{O}$ \\
\hline 283.60 & 283.95 & 284.30 & 70 & SE & 42 & $\mathrm{O}$ \\
\hline 288.65 & 288.93 & 289.22 & 66 & $N$ & 294 & SD \\
\hline 289.60 & 289.60 & 289.60 & $\mathrm{H}$ & & NA & $\mathrm{SD} ; \mathrm{F}(.02,300)$ \\
\hline 309.10 & 309.20 & 309.30 & 39 & $N$ & 276 & SD \\
\hline 322.10 & 322.55 & 323.00 & 74 & $N$ & 276 & SD \\
\hline 326.40 & 327.50 & 328.60 & 84 & $N$ & 285 & SD \\
\hline 335.00 & 335.35 & 335.70 & 70 & $N$ & 276 & SD \\
\hline 346.25 & 346.63 & 347.00 & 72 & SE & 42 & O \\
\hline 346.75 & 347.13 & 347.50 & 72 & SE & 42 & $\mathrm{O}$ \\
\hline 347.20 & 347.35 & 347.50 & 50 & $\mathrm{SE}$ & 42 & $\mathrm{O}$ \\
\hline 349.00 & 349.00 & 349.00 & $\mathrm{H}$ & & NA & SD \\
\hline 350.00 & 350.00 & 350.00 & $\mathrm{H}$ & & NA & SD \\
\hline 350.75 & 350.88 & 351.00 & 45 & W & 168 & $\mathrm{SD} ; \mathrm{F}(.03,350)$ \\
\hline 352.50 & 352.75 & 353.00 & 63 & W & 168 & SD \\
\hline 353.60 & 353.80 & 354.00 & 58 & $\mathrm{NE}$ & 312 & SD \\
\hline 361.75 & 361.75 & 361.75 & $\mathrm{H}$ & & NA & $\mathrm{O}$ \\
\hline 364.00 & 364.50 & 365.00 & 76 & E & 348 & $\mathrm{O}$ \\
\hline 369.00 & 369.00 & 369.00 & $\mathrm{H}$ & & NA & O \\
\hline 380.50 & 380.80 & 381.10 & 67 & $S$ & 51 & SD \\
\hline 381.35 & 382.28 & 383.20 & 82 & $\mathrm{~S}$ & 60 & SD \\
\hline 381.80 & 382.10 & 382.40 & 67 & S & 51 & SD \\
\hline 384.95 & 385.23 & 385.50 & 66 & $\mathrm{~S}$ & 60 & SD \\
\hline 388.30 & 388.30 & 388.30 & $\mathrm{H}$ & & NA & O \\
\hline 391.50 & 391.50 & 391.50 & $\mathrm{H}$ & & NA & $\mathrm{O}$ \\
\hline 391.90 & 391.90 & 391.90 & $\mathrm{H}$ & & NA & $\mathrm{O}$ \\
\hline 394.20 & 394.20 & 394.20 & $\mathrm{H}$ & & NA & $\mathrm{O}$ \\
\hline 394.40 & 394.40 & 394.40 & $\mathrm{H}$ & & NA & $\mathrm{O}$ \\
\hline
\end{tabular}


Table D-5. Characteristics of fractures identified on borehole televiewer log, and measured flow rates at selected depths, site 4, well 19-250, lower part of the Passaic Formation, south-central Newark Basin, New Jersey--Continued

\begin{tabular}{|c|c|c|c|c|c|}
\hline \multicolumn{3}{|c|}{$\begin{array}{c}\text { Depth of fracture } \\
\text { (feet below land surface) }\end{array}$} & \multicolumn{2}{|c|}{ Fracture orientation } & \multirow{2}{*}{$\begin{array}{l}\text { Condition of } \\
\text { fracture, and flow } \\
\text { rate where } \\
\text { determined }\end{array}$} \\
\hline Top & Center & Bottom & $\begin{array}{c}\text { Dip } \\
\text { (degrees) }\end{array}$ & $\begin{array}{c}\text { Strike } \\
\text { (degrees) }\end{array}$ & \\
\hline 394.50 & 394.50 & 394.50 & $\mathrm{H}$ & NA & 0 \\
\hline 401.30 & 401.70 & 402.10 & $73 \mathrm{~S}$ & 60 & $\mathrm{SD} ; \mathrm{F}(.03,400)$ \\
\hline 414.75 & 415.00 & 415.25 & $63 \mathrm{~S}$ & 78 & SD \\
\hline
\end{tabular}


Five zones of anomalously high radioactivity centered at depths of $19,102,125,392$, and $409 \mathrm{ft}$ are recorded on the gamma log of well 19-250 (pl. 3). All the gamma peaks coincide with areas of alternating light and dark laminae of the calcareous silty mudstones and dense, dark mudstones. Only one such intercalated area (33-36 ft) is not associated with an elevated gamma anomaly. Minor radioactive zones are centered at 72,173, 213, and $249 \mathrm{ft}$. The stationary gamma spectra for the peaks of the gamma log and two background spectra are shown in figure D-4. The gamma spectra of the more radioactive intervals show higher integrated counts for shorter counting periods than the background spectra (table D-2). The ${ }^{238} \mathrm{U}$ peaks (consisting of the ${ }^{214} \mathrm{Bi}$ peaks $0.61,1.12,1.76$, and $2.204 \mathrm{MeV}$ ) are definite in the spectra for the radioactive intervals, but only peaks for ${ }^{40} \mathrm{~K}$ and of ${ }^{208} \mathrm{Tl}$ are definable in the background spectra.

The anomalously high gamma peaks are associated with moderately to highly fractured intervals in well 19-250. The fractures are almost evenly distributed between high-angle open and low-angle open in the three shallowest zones of anomalously high radioactivity. The HPFM indicates that most of the water movement in the well is in the section from 40 to $125 \mathrm{ft}$ encompassing the deeper two of these three zones ( $\mathrm{pl} .4$ ) and also the slightly radioactive zone at $72 \mathrm{ft}$. Spontaneous-potential and single-point-resistance logs show a significant response in these radioactive zones, indicating the possible presence of water-bearing fractures. Minimal, but detectable, amounts of water are produced from the depth interval of 10 to $15 \mathrm{ft}$; the calcite in the alternating light and dark laminae, however, is corroded, etched, and pitted, indicating that it is undergoing dissolution by percolating water. The deepest radioactive zones (at 392 and $409 \mathrm{ft}$ ) are characterized by the presence of high-angle sealed fractures and only a few open fractures. The absence of flowing water in these fractures is verified by the HPFM log. The responses of the spontaneouspotential and single-point-resistance logs are smaller in these zones than in the shallowest (above $125 \mathrm{ft}$ ) part of the section and may be due to subtle variations in lithology.

The dominant lithology in well 19-249 is medium dark gray (N4) to light gray (N7) silty mudstone. In general, the mudstone is massive with locally thin, convoluted beds. The mudstone at depths of $39 \mathrm{ft}$ and $43 \mathrm{ft}$ is bleached to a pinkish gray (5YR8/1). Calcite is abundant in the matrix as speckling. Some clay mottling and nodules also are present. Pyrite and limonite are rare.

The fracture-density histogram, which begins at a depth of $10 \mathrm{ft}(\mathrm{pl} .4)$, shows that the most highly fractured zone is located within the uppermost $50 \mathrm{ft}$ of the section (transition zone), immediately below the regolith. The highly fractured interval, 10 to $15 \mathrm{ft}$, contains 32 fractures. The number of fractures decreases to 10 fractures per 5- $\mathrm{ft}$ interval with increasing depth in the well. Open fractures dominate throughout the well; sealed fractures are rare and typically are cemented with pyrite and calcite. A fissured zone, present at a depth of about 44 to $45 \mathrm{ft}$, is indicated as a possible water-bearing zone by a sharp increase in response on the single-point-resistance log. The decrease in spontaneous potential and increase in single-point resistance with depth likely reflect the decrease in the number of fractures with depth and thus correspond with the data illustrated in the fracture-density histogram.

Fracture-surface mineralogy below a depth of $40 \mathrm{ft}$ is dominated by calcite and pyrite. The absence of limonite indicates that oxidizing water has not percolated below this depth. 


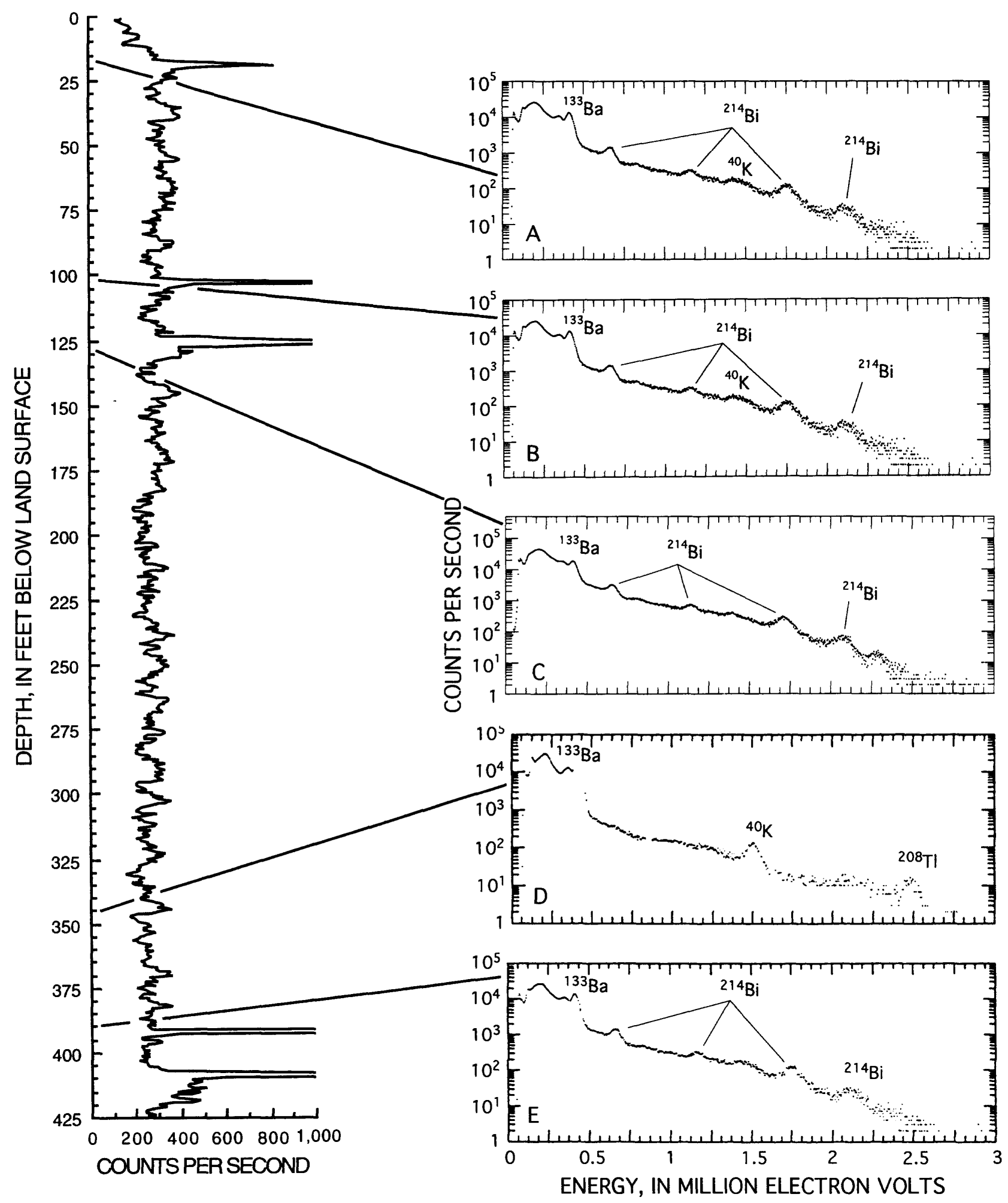

Figure D-4. Gamma log of well 19-250, sitc 4, Passaic Formation, south-central Newark Basin, New Jersey, and stationary gamma spectra at the following depths, in fect: (A) 18.75, (B) 102.5, (C) 125.5 , (D) 345.0 , and (E) 391.75 . 
No zones of anomalously high radioactivity are apparent on the gamma log of well 19-249 (pl. 3). Light and dark laminae of calcareous siltstone and mudstone, the typically radioactive lithology in the Passaic Formation, were not observed in the strata intercepted by this well.

Borehole 19-249 yields little water; during sampling, it produced $0.125 \mathrm{gal} / \mathrm{min}$ with $40 \mathrm{ft}$ of drawdown. During development, a yield of $1 \mathrm{gal} / \mathrm{min}$ could not be sustained. High-angle open fractures, which commonly produce little water (Michalski, 1990), predominate in this well (pl. 4).

Three boreholes completed as observation wells (21-249, 21-250, and 21-251) were sampled at site 4 . The sampling depths in these three wells differed. The resulting variations in the chemical quality of water samples collected from them were significant but not extreme (app. C). Concentrations of calcium, the dominant major cation (fig. 8), ranged from 52 to $68 \mathrm{mg} / \mathrm{L}$. Concentrations of magnesium and sodium were lower than those of calcium, and concentrations of magnesium varied more than those of calcium and sodium. Concentrations of potassium were high $(8.6$ and $10 \mathrm{mg} / \mathrm{L})$ in samples from wells $21-249$ and $21-250$, respectively.

Bicarbonate, the dominant major anion in samples from two of the three wells, was present in high concentrations ( 180 and $156 \mathrm{mg} / \mathrm{L}$ as alkalinity). The concentration of bicarbonate was relatively low (alkalinity of $114 \mathrm{mg} / \mathrm{L}$ ) in the sample from well 19-249, and chloride was the dominant anion. Concentrations of chloride varied significantly in water samples from the three wells, ranging from $14 \mathrm{mg} / \mathrm{L}$ (well 19-251) to $110 \mathrm{mg} / \mathrm{L}$ (well 19-249) (fig. 8). Concentrations of sulfate ranged from 41 to $71 \mathrm{mg} / \mathrm{L}$ in samples from these wells; this concentration range is narrow compared to those of bicarbonate and chloride. Concentrations of silica were high, especially in water from well 19-249 $(42 \mathrm{mg} / \mathrm{L})$. Specific conductance ranged from 422 to $630 \mu \mathrm{S} / \mathrm{cm}$.

Concentrations of DO were variable but relatively low. Water samples from the two shallower wells (19-249 and 19-251) were slightly oxidizing, but the low DO content $(0.6 \mathrm{mg} / \mathrm{L})$ in the deepest well (19-250) indicated that water from this well was reducing. Nitrate was not detected in the deepest of the three wells, but was detected in concentrations as high as $1.6 \mathrm{mg} / \mathrm{L}(19-249)$ in samples from the two shallower wells. Ammonia and iron were present in high concentrations in the water from the deepest well $(0.06 \mathrm{mg} / \mathrm{L}$ and $110 \mu \mathrm{g} / \mathrm{L}$, respectively). These concentrations are much higher than those measured in water from the two shallower wells, confirming that water from the deepest well is reducing. Water from all three wells was slightly alkaline; $\mathrm{pH}$ ranged from 7.1 in the shallowest well (19-249) to 7.5 in the deepest well (19-250).

Concentrations of strontium were greater than those of all other trace elements measured in water from all three wells; concentrations ranged from 210 to $430 \mu \mathrm{g} / \mathrm{L}$. Concentrations of barium were relatively low, ranging from 13 to $80 \mu \mathrm{g} / \mathrm{L}$, and concentrations of lithium were relatively high, ranging from 19 to $86 \mu \mathrm{g} / \mathrm{L}$. Many other trace elements, including aluminum, arsenic, cadmium, lead, molybdenum, nickel, and zinc, were detected in low concentrations $(20 \mu \mathrm{g} / \mathrm{L}$ or less) in water samples from this site, especially in the reducing water from well 19-250.

Ground-water samples from site 4 contained high dissolved radioactivity, which is expected where many strongly radioactive strata are present. A high dissolved gross alpha-particle activity of $19 \mathrm{pCi} / \mathrm{L}$ and a high dissolved gross beta-particle activity of $24 \mathrm{pCi} / \mathrm{L}$ were measured in the sample from well 19-250. Concentrations of uranium isotopes $(18.1 \mathrm{pCi} / \mathrm{L})$ and ${ }^{226} \mathrm{Ra}$ 
$(2.4 \mathrm{pCi} / \mathrm{L})$ also were high. The concentration of ${ }^{222} \mathrm{Rn}$, at $22,000 \mathrm{pCi} / \mathrm{L}$, measured in the water sample from well 19-250 was extremely high. Activities of dissolved radon were high in water from wells 19-249 and 19-251 (1,400 and 1,730 pCi/L, respectively); however, concentrations of gross alpha-particle activity ( 6.34 and $3.1 \mathrm{pCi} / \mathrm{L}$, respectively), uranium isotopes (sum of activities less than $4 \mathrm{pCi} / \mathrm{L}$ in both samples), and radium isotopes (each less than $1 \mathrm{pCi} / \mathrm{L}$ ) were low. Gross beta-particle activity was $13 \mathrm{pCi} / \mathrm{L}$ in the sample from well $19-249$, but only $4.3 \mathrm{pCi} / \mathrm{L}$ in the sample from well 19-251. Concentrations of tritium for these three samples ranged from 61 to $93 \mathrm{pCi} / \mathrm{L}$, indicating that ground water at this site is of recent (post-1960 recharge) origin (Hendry, 1988).

\section{Site 5}

The rocks in borehole 23-1076 consist of a sequence of about $25 \mathrm{ft}$ of grayish-red (10R4/2), grayish-red-purple (5RP4/2), and brownish-gray (5YR4/1) silty mudstones underlain by a sequence of $30 \mathrm{ft}$ of medium-dark gray (N4) to medium gray (N5) mudstones (pl. 5). These rocks (like those from sites 3 and 4 ) reflect cyclic sedimentation in a large lake with marginal mudflats and alternating transgressive and regressive stages. The reddish mudstones are mudflat deposits, whereas the grayish mudstones represent deep lakebed deposits.

The medium gray mudstones generally are massive, whereas laminar bedding is common in the medium-dark gray mudstones, which have a striped appearance as a result of the presence of zones of thinly intercalated calcareous siltstone (pl. 5). Bedding in the grayish-red silty mudstones is massive to laminar or convoluted. The laminar bedding in the dark gray mudstones, which reflects a low-energy depositional environment in a deep lake, was preserved because bioturbation generally does not occur in the deeper parts of an organic-carbon-rich, anoxic lake. Intercalated siltstones may represent deposition during the storms or distal deposition from large tidal or stream channels. The massive bedding in the medium gray and grayish-red mudstones represents a shallow lake, lake-margin, or playa-flat depositional environment, where bioturbation destroyed any laminae that may have been present. The convoluted bedding in the grayish-red mudstones represents either random overloading of mud surfaces by rapid deposition of detritus or dense mudcracking; both features are common on playa mudflats. The red color is the result of exposure in a subareal environment and the resulting oxidation of iron and organic matter.

Mottling of convoluted and massive beds resulted when calcite filled the pores created by wormburrowing and plant roots (trace fossils) in the paleosol developed on the playa mudflats.

Postdepositional calcite is locally abundant throughout the matrix, primarily as fillings in small, scattered voids and in mudcracks. Postdepositional euhedral pyrite is less abundant, but is present locally in the gray mudstone beds, especially in the medium-dark gray mudstones.

Four whole-rock chemical analyses and 11 gamma-spectrometric analyses were completed on rock samples from borehole 23-1076. The results indicate that the concentration of uranium in the radioactive stratum at a depth of $42.3 \mathrm{ft}$ may be as high as $6,000 \mathrm{ppm}$ (app. B-1; sample 5-8). The next highest concentration of equivalent uranium--540 ppm--was found at $42.4 \mathrm{ft}$ (app. B-2). A second radioactive zone at $57 \mathrm{ft}$ had an equivalent uranium concentration of $11 \mathrm{ppm}$. Uranium is strongly enriched relative to thorium in all samples of the dark gray mudstone, whereas concentrations of thorium commonly exceed those of uranium in samples of the red mudstone (app. B-2). 
This trend of uranium enrichment is consistent with the conclusion of Turner-Peterson (1985) that the dark gray and black organic-rich mudstones in the central Newark Basin are major repositories of uranium.

Results of the whole-rock chemical analyses (app. B-1) also indicate that the gray mudstones are highly enriched in trace elements such as lead, molybdenum, vanadium, and zinc. The concentrations of uranium and organic carbon in the rock samples from site 5 are an order of magnitude greater in the black mudstones than in the red mudstones.

The spontaneous-potential log, single-point-resistance log, fracture-density histogram, and fracture-surface mineralogy for borehole 23-1076 are shown on plate 6 . The caliper log and BHTV $\log$ from nearby well 23-1083 are also shown because borehole 23-1076 was sealed before the caliper and BHTV logs could be run. The fracture-density histogram for borchole 23-1076, which begins at a depth of $10 \mathrm{ft}$, shows that, as in all the boreholes and wells, the most highly fractured section is located in the shallowest strata (about 10 to $25 \mathrm{ft}$ ) and forms the transition zone between regolith and bedrock. The highly fractured section from 10 to $25 \mathrm{ft}$ is located in the grayish-red mudstone. The spontaneous-potential log for this section deflects toward positive values as it does for the other boreholes and wells. Fractures are moderately dense from $25 \mathrm{ft}$ to about $40 \mathrm{ft}$. The number of fractures in the 5 - $\mathrm{ft}$ intervals that comprise the section from the 40 to $50 \mathrm{ft}$ is low $(<5)$. Another moderately fractured section is located from 50 to $60 \mathrm{ft}$; the BHTV log and the caliper log correlate with the fracture-density histogram in delineating this section. The caliper log shows several enlargements in well diameter, which represent major fracture zones, in the 50-to-55-ft and 57-to-62-ft intervals. Depths of these enlargements correspond with depths of major fractures shown on the BHTV (pl. 6).

The orientations of the fractures intersecting well 23-1083 as shown on the BHTV log are listed in table D-6. Fractures are predominantly low-angle and open. High-angle fractures, which are rare, are found predominantly in the section from 31 to $37 \mathrm{ft}$ and, to a lesser degree, below $40 \mathrm{ft}$. A high-angle open fracture shown on the fracture-density histogram appears nearly vertical on the BHTV log for the interval from 40 to $45 \mathrm{ft}$ (pl. 6; table D-6). The BHTV log also shows several high-angle fractures in the section from 49 to $60 \mathrm{ft}$. The BHTV log shows many of the thin lowangle open fractures found in the core from 26 to $40 \mathrm{ft}$, but some are so close together that they appear to be as one fracture on the BHTV log.

The responses on the spontaneous-potential log and single-point-resistance log correlate with the fracture-density histogram. The highly fractured section from 10 to $25 \mathrm{ft}$ contains only low-angle open fractures and shows a high positive response on the spontaneous-potential log and a low response on the single-point-resistance log, indicating this section may contain water. The fractured intervals from 35 to $40 \mathrm{ft}, 50$ to $55 \mathrm{ft}$, and especially at 57 to $62 \mathrm{ft}$ also show large responses on the electric logs (pl. 6). The sharp responses on the electric logs indicate the probable presence of water-bearing fractures at a depth of 50 to $55 \mathrm{ft}$ and 57 to $62 \mathrm{ft}(\mathrm{pl} .6)$ and possibly at $35 \mathrm{ft}$ and $40 \mathrm{ft}$. Deflections on the spontaneous-potential and single-point-resistance logs are inconclusive, however, because they appear in both the unfractured interval from 40 to $50 \mathrm{ft}$ and the fractured interval from 50 to $60 \mathrm{ft}$, which indicates that these deflections may be more indicative of changes in lithology than of the presence of water-bearing fractures. 
Table D-6. Characteristics of fractures identified on borehole televiewer log, site 5, well 23-1083, lower part of the Passaic Formation, south-central Newark Basin, New Jersey

[H, horizontal; V, vertical; N, north; S, south; NW, northwest; NE, northeast; SW, southwest; SE, southeast; NA, not applicable; $\mathrm{O}$, open; SD, sealed]

\begin{tabular}{|c|c|c|c|c|c|}
\hline \multicolumn{3}{|c|}{$\begin{array}{c}\text { Depth of fracture } \\
\text { (feet below land surface) }\end{array}$} & \multicolumn{2}{|c|}{ Fracture orientation } & \multirow[b]{2}{*}{$\begin{array}{l}\text { Condition of } \\
\text { fracture }\end{array}$} \\
\hline Top & Center & Bottom & $\begin{array}{c}\text { Dip } \\
\text { (degrees) }\end{array}$ & $\begin{array}{c}\text { Strike } \\
\text { (degrees) }\end{array}$ & \\
\hline 26.60 & 26.60 & 26.60 & $\mathrm{H}$ & NA & O \\
\hline 27.07 & 27.07 & 27.07 & $\mathrm{H}$ & NA & O \\
\hline 27.00 & 27.20 & 27.40 & $29 \mathrm{~W}$ & 168 & 0 \\
\hline 27.20 & 27.20 & 27.20 & $\mathrm{H}$ & NA & $\mathbf{O}$ \\
\hline 27.50 & 28.75 & 30.00 & $74 \mathrm{SW}$ & 260 & $\mathrm{O}$ \\
\hline 28.60 & 28.60 & 28.60 & $\mathrm{H}$ & NA & O \\
\hline 29.00 & 29.00 & 29.00 & $\mathrm{H}$ & NA & O \\
\hline 30.00 & 30.90 & 31.80 & $70 \mathrm{~W}$ & 168 & $\mathbf{O}$ \\
\hline 30.80 & 30.80 & 30.80 & $\mathrm{H}$ & NA & $\mathbf{O}$ \\
\hline 31.00 & 31.00 & 31.00 & $\mathrm{H}$ & NA & $\mathbf{0}$ \\
\hline 31.20 & 31.50 & 31.80 & $57 \mathrm{SW}$ & 132 & $\mathbf{O}$ \\
\hline 31.20 & 31.30 & 31.40 & $21 \mathrm{E}$ & 330 & $\mathrm{O}$ \\
\hline 31.90 & 32.35 & 32.80 & $55 \mathrm{~S}$ & 78 & $\mathrm{O}$ \\
\hline 32.20 & 32.30 & 32.40 & $16 \mathrm{E}$ & 330 & $\mathrm{O}$ \\
\hline 32.50 & 32.65 & 32.80 & $24 \mathrm{E}$ & 330 & O \\
\hline 32.90 & 33.25 & 33.60 & $45 \mathrm{~S}$ & 60 & O \\
\hline 33.00 & 33.80 & 34.60 & $65 \mathrm{~S}$ & 60 & 0 \\
\hline 34.80 & 35.20 & 35.60 & $48 \mathrm{E}$ & 6 & 0 \\
\hline 35.80 & 36.03 & 36.25 & $32 \mathrm{~N}$ & 258 & 0 \\
\hline 37.00 & 37.00 & 37.00 & $\mathrm{H}$ & NA & 0 \\
\hline 37.40 & 37.50 & 37.60 & $15 \mathrm{E}$ & 348 & O \\
\hline 37.60 & 37.70 & 37.80 & $15 \mathrm{E}$ & 348 & 0 \\
\hline 38.00 & 38.00 & 38.00 & $\mathrm{H}$ & NA & 0 \\
\hline 38.20 & 38.20 & 38.20 & $\mathrm{H}$ & NA & 0 \\
\hline 38.40 & 38.40 & 38.40 & $\mathrm{H}$ & NA & 0 \\
\hline
\end{tabular}


Table D-6. Characteristics of fractures identified on borehole televiewer log, site 5, well 23-1083, lower part of the Passaic Formation, south-central Newark Basin, New Jersey--Continued

\begin{tabular}{|c|c|c|c|c|c|}
\hline \multicolumn{3}{|c|}{$\begin{array}{c}\text { Depth of fracture } \\
\text { (feet below land surface) }\end{array}$} & \multicolumn{2}{|c|}{ Fracture orientation } & \multirow[b]{2}{*}{$\begin{array}{l}\text { Condition or } \\
\text { fracture }\end{array}$} \\
\hline Top & Center & Bottom & $\begin{array}{c}\text { Dip } \\
\text { (degrees) }\end{array}$ & $\begin{array}{c}\text { Strike } \\
\text { (degrees) }\end{array}$ & \\
\hline 38.60 & 38.60 & 38.60 & $\mathrm{H}$ & NA & O \\
\hline 39.20 & 39.20 & 39.20 & $\mathrm{H}$ & NA & O \\
\hline 39.30 & 39.30 & 39.30 & $\mathrm{H}$ & NA & 0 \\
\hline 39.90 & 40.25 & 40.60 & $46 \mathrm{~N}$ & 276 & 0 \\
\hline 40.20 & 40.90 & 41.60 & $63 \mathrm{~W}$ & 168 & O \\
\hline 40.00 & 42.50 & 45.00 & $\mathrm{~V}$ & NA & $\mathrm{O}$ \\
\hline 41.40 & 41.65 & 41.90 & $36 \mathrm{SW}$ & 132 & 0 \\
\hline 42.00 & 42.00 & 42.00 & $\mathrm{H}$ & NA & 0 \\
\hline 45.20 & 45.20 & 45.20 & $\mathrm{H}$ & NA & 0 \\
\hline 45.40 & 45.40 & 45.40 & $\mathrm{H}$ & NA & 0 \\
\hline 45.90 & 45.90 & 45.90 & $\mathrm{H}$ & NA & o \\
\hline 47.00 & 47.30 & 47.60 & $40 \mathrm{~W}$ & 150 & 0 \\
\hline 47.80 & 47.80 & 47.80 & $\mathrm{H}$ & NA & $\mathrm{O}$ \\
\hline 48.00 & 48.00 & 48.00 & $\mathrm{H}$ & NA & $\mathrm{O}$ \\
\hline 48.40 & 48.50 & 48.60 & $15 \mathrm{~N}$ & 273 & O \\
\hline 49.00 & 49.00 & 49.00 & $\mathrm{H}$ & NA & 0 \\
\hline 49.40 & 49.40 & 49.40 & $\mathrm{H}$ & NA & 0 \\
\hline 49.60 & 50.95 & 52.30 & $63 \mathrm{~W}$ & 168 & 0 \\
\hline 52.00 & 53.00 & 54.00 & $59 \mathrm{~S}$ & 78 & 0 \\
\hline 52.00 & 52.60 & 53.20 & $54 \mathrm{~W}$ & 168 & 0 \\
\hline 54.40 & 57.35 & 60.30 & $81 \mathrm{~N}$ & 258 & 0 \\
\hline 63.80 & 63.80 & 63.80 & $\mathrm{H}$ & NA & 0 \\
\hline 70.20 & 70.20 & 70.20 & $\mathrm{H}$ & NA & 0 \\
\hline
\end{tabular}


In the core, fracture-surface mineralogy is dominated by clay and limonite to a depth of $45 \mathrm{ft}$. In the lower part of the core (below $45 \mathrm{ft}$ ), calcite, pyrite, and clay dominate. Between 35 and $50 \mathrm{ft}$, pyrite and limonite coexist; limonite dominates above this zone, whereas pyrite dominates below it, indicating that oxygenated water is limited to depths shallower than about $35 \mathrm{ft}$. The presence of strongly anoxic (oxygen-depleted) water in this borehole (app. C) confirms the minimal penetration of oxygenated water into the deep strata. Calcite is found in abundance below $40 \mathrm{ft}$ (pl. 6), indicating that weathering and water circulation are less extensive below this depth than above it.

Two zones of anomalously high radioactivity, one at $42 \mathrm{ft}$ and the other at $57 \mathrm{ft}$, coincide with the presence of the intercalated white calcareous siltstone and gray mudstone (pl. 5). Radioactive anomalies also were found in this lithology in the lower part of the Passaic Formation at sites 3 and 4 . Fractures are virtually absent from the more radioactive zone (at $42 \mathrm{ft}$ ) but are common in the less radioactive zone (at $57 \mathrm{ft}$ ). The gamma $\log$ and stationary gamma spectra that identify the two major peaks are shown in figure D-5. The gamma spectra recorded total integrated counts for the shallower peak to be five times greater than those for the deeper peak for the same counting time (table D-2). The ${ }^{238} \mathrm{U}$-series peak $\left({ }^{214} \mathrm{Bi}\right.$ peaks at energies of $0.61,1.12,1.76$, and 2.204 $\mathrm{MeV}$ ) are identified in both spectra; however, the spectra at $57 \mathrm{ft}$ also contain the ${ }^{40} \mathrm{~K}$ peak. The uranium-series peaks at $42 \mathrm{ft}$ are more definite (more clearly above background, hence more resolvable) and have a greater number of counts recorded than the uranium-series peaks at $57 \mathrm{ft}$.

The yield from borehole $23-1076$ was greater than $40 \mathrm{gal} / \mathrm{min}$ with little decrease in head after 1 hour of pumping. Shallow industrial wells nearby produce up to $100 \mathrm{gal} / \mathrm{min}$. Despite the thinness of the regolith, wells in the area are productive, possibly as a result of the large number of open, bedding-plane fractures directly beneath the regolith. Such fractures are considered to contain the bulk of the water produced from wells in the Newark Basin (Michalski, 1990).

Calcium was the dominant cation $(94 \mathrm{mg} / \mathrm{L}$ ) and bicarbonate was the dominant anion (alkalinity of $217 \mathrm{mg} / \mathrm{L}$ ) in water from borehole 23-1076 (app.C), as illustrated by the Stiff diagram in figure 8 . Sodium $(28 \mathrm{mg} / \mathrm{L})$ and chloride $(71 \mathrm{mg} / \mathrm{L})$ were the second most abundant cation and anion, respectively. A specific conductance of $748 \mu \mathrm{S} / \mathrm{cm}$ indicates that water from borehole 231076 contained significant amounts of dissolved mineral matter.

The concentration of DO was $0.2 \mathrm{mg} / \mathrm{L}$. The high concentrations of iron and manganese $(1,300$ and $660 \mu \mathrm{g} / \mathrm{L}$, respectively) in this slightly alkaline $(\mathrm{pH} 7.2)$ ground water is indicative of strongly reducing conditions (Hem, 1985; Berner, 1981).

Concentrations of barium and strontium were high $(1,100$ and $590 \mu \mathrm{g} / \mathrm{L}$, respectively); the concentration of lithium $(33 \mu \mathrm{g} / \mathrm{L})$ also was relatively high. Concentrations of aluminum and zinc were low ( 20 and $9 \mu \mathrm{g} / \mathrm{L}$, respectively).

Gross alpha-particle and gross beta-particle activity in the sample of water from borehole 23-1076 was high ( 66.4 and $25 \mathrm{pCi} / \mathrm{L}$, respectively). Total uranium-isotope activity, however, was low $(1.57 \mathrm{pCi} / \mathrm{L})$. Concentrations of ${ }^{226} \mathrm{Ra}$ and ${ }^{228} \mathrm{Ra}(22.5$ and $3.4 \mathrm{pCi} / \mathrm{L}$, respectively) were greater in water from borehole 23-1076 than in water from any of the other boreholes and wells sampled. The concentration of ${ }^{222} \mathrm{Rn}$ was not determined, but was measured at a concentration of $1,320 \mathrm{pCi} / \mathrm{L}$ in the adjacent well $23-1083$. 


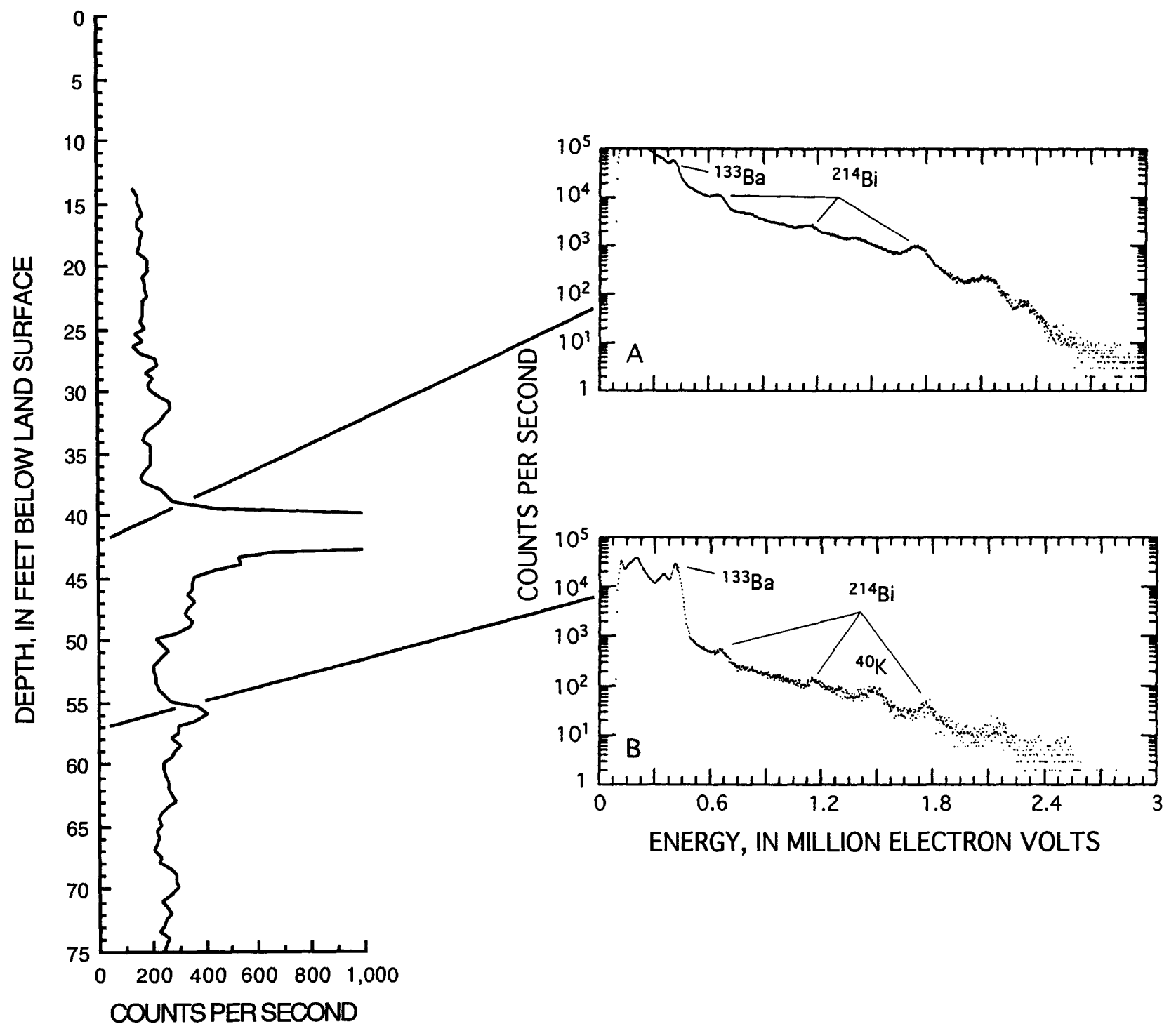

Figure D-5. Gamma log of well 23-1083, sitc 5, Passaic Formation, south-central Newark Basin, New Jerscy, and stationary gamma spectra at the following depths, in fect: (A) 39.0 and (B) 54.0, stratigraphically equivalent to the following depths in borehole 23-1076, in feet: (A) 42.0 and (B) 57.0 . 


\section{Site 6}

The dominant rock types penetrated by well $03-286$ at site 6 are a pale red (5R6/2; 10R6/2) siltstone and a grayish red (10R4/2) sandstone (pl. 5). Fine-grained pale red (10R6/2) sandstone also is present in places. Bedding in the pale red siltstones is massive to laminar and, in places, convoluted. The mudstones are primarily massive to convoluted. In general, the finegrained sandstones are laminated and, from 77 to $95 \mathrm{ft}$, are cross-bedded. Sedimentary structures and trace fossils such as mudcracks, worm burrows, and rootcasts are rare in the core. The few that are present are filled with calcite and clay and, therefore, are easily seen. The core consists primarily of a series of gradational fining-upward sequences. Commonly, the fine-grained sandstones are the basal lithology; they grade upward into a siltstone and are capped by a mudstone. Six such complete fining-upward sequences are identified in the core at the following depths: 49 to $60 \mathrm{ft}$, 60 to $69 \mathrm{ft}, 72$ to $78 \mathrm{ft}, 78$ to $96 \mathrm{ft}, 106$ to $114 \mathrm{ft}$, and 114 to $119 \mathrm{ft}(\mathrm{pl}$. 5). These complete sequences are separated by partial sequences that were eroded after deposition.

The fracture-density histogram for well 03-286, beginning at a depth of $55 \mathrm{ft}$, shows the highly fractured section (the transition zone) at the base of the regolith, as is the case for all the cores (pl. 6). Most fractures in strata penetrated by the well are the low-angle open type; highangle fractures, either open or sealed, are rare. The uppermost 5-ft interval of the transition zone contains 26 fractures, of which more than 90 percent are low-angle open. The transition zone is in a massive grayish-red mudstone. A highly fractured interval, from 75 to $80 \mathrm{ft}$, contains 20 fractures; a fissured zone is present from 76.5 to $77 \mathrm{ft}$. The highly fractured interval is in a massive pale red siltstone and a grayish-red mudstone. Fractures decrease in number with depth; moderately fractured zones are interspersed between the slightly fractured intervals of rock strata from $80 \mathrm{ft}$ to $125 \mathrm{ft}$. The response on the spontaneous-potential log also decreases (becomes less positive) with depth, especially below the base of the transition zone. A positive response corresponds to the highly fractured interval at 75 to $80 \mathrm{ft}$. The single-point-resistance log was highly erratic for this well and for the others at this site, and yielded no interpretable information. The high frequency of large fluctuations in the log responses could result from a combination of several phenomena, including the many variations in lithology within short vertical distances and the large number of open fractures, many of which may be water-bearing. The caliper log indicates that the well wall is irregular throughout, possibly because of the many fractures (pl. 6). (The caliper tool used to $\log$ this well was more sensitive than the tool used to log the other wells.)

Sealed fractures are typically sealed with calcite and clay. Fracture-surface mineralogy also is dominated by calcite and clay, with trace quantities of limonite. Limonite is present in trace quantities to a depth of $125 \mathrm{ft}$, which could be the extent of penetration of oxidizing water. Postdepositional calcite is primarily a void-filling material; in the matrix, it is present as speckling and mottling. Some clay nodules are present in fracture zones.

A minor (less than $200 \mathrm{cps}$ ) zone of anomalously high radioactivity was identified from the gamma $\log$ at a depth of about $113 \mathrm{ft}$ in well $03-286$. This slightly elevated gamma count was emitted from a pale red fine-grained sandstone that forms the basal member of a fining-upward sequence and a gray bleached mudstone that caps the top of the fining-upward sequence below. The stratigraphic position (basal sandstone) of this radioactive zone is similar to that of much more highly radioactive zones in the Stockton Formation. 
Yields in well 03-286 were moderate. During sampling, the well yielded $10 \mathrm{gal} / \mathrm{min}$ with only $40 \mathrm{ft}$ of drawdown. During development, a yield of $10 \mathrm{gal} / \mathrm{min}$ was maintained for 1 hour. The presence of dense and well-connected fractures and deeply weathered rocks is conducive to the storage and flow of water; therefore, significant well yields would be expected.

The lithology of the strata penetrated by well $03-287$ is dominated by a grayish-red (10R4/2) or pale red (10R6/2) siltstone. Minor lithologies are pale red (10R6/2), sometimes grayish orange-pink (5YR7/2) or very pale orange (10YR8/2), fine- to very fine-grained sandstone, and grayish-red (10R4/2) mudstone. Bedding in the siltstone is massive to convoluted to laminated. The fine-grained sandstone is predominantly massive, laminated in places, and, rarely, cross-bedded. Mudstones are typically massive to convoluted and laminated in places. Twelve gradational fining-upward sequences were identified in the core. Most begin with basal sandstone, grade upward into siltstone, and are capped by mudstone. The exceptions are the incomplete sequences at the following depths: 145 to $150 \mathrm{ft}$ (does not contain siltstone) and 150 to $155 \mathrm{ft}$ (is not capped by mudstone).

Five bleached zones at 47, 73, 78, 103, and $113 \mathrm{ft}$ are present in siltstone, sandstone, siltstone, sandstone, and mudstone, respectively. Postdepositional calcite is abundant in the matrix as void filling and as speckling. Clay nodules also are abundant (pl. 5). Calcite- and clay-filled root casts and worm burrows are rare, however, and are absent below $70 \mathrm{ft}$.

The fracture-density histogram for well $03-287$, beginning at depth of $40 \mathrm{ft}$, shows several highly fractured intervals (pl. 6)--from 50 to $55 \mathrm{ft}$ (at the base of the regolith), from 60 to $65 \mathrm{ft}$, from 80 to $85 \mathrm{ft}$, and from 105 to $110 \mathrm{ft}$. A fissured zone is present from 72.5 to $74 \mathrm{ft}$. All of the highly fractured intervals, except the interval from 50 to $55 \mathrm{ft}$, but including the fissured zone, coincide with a bedding-plane contact between mudstone and siltstone. The caliper log shows that the surface of the well wall is highly irregular in, or adjacent to, three intervals or sections in which the rocks are highly fractured at about $45 \mathrm{ft}, 65 \mathrm{ft}$, and 95 to $110 \mathrm{ft}$. The responses of the spontaneouspotential $\log$ and single-point-resistance $\log$ were not interpretable.

Low-angle open fractures predominate and commonly are the only type of fracture observed in a given interval, although a few high-angle open fractures are present. High-angle sealed fractures are rare; where present, they are cemented with calcite and clay. The fracturesurface mineralogy generally is dominated by calcite and clay, with traces of limonite to depths of $160 \mathrm{ft}$, which may be the extent of the penetration of oxidizing water. Oxidizing water was pumped from the well.

Yields from well 03-287 during sampling were $10 \mathrm{gal} / \mathrm{min}$ with only $40 \mathrm{ft}$ of drawdown. During development, a yield of $12 \mathrm{gal} / \mathrm{min}$ was maintained for 1 hour. The presence of dense fracturing, many open bedding-plane fractures, and deep weathering is conducive to significant yields.

No zones of anomalously high radioactivity were identified in well $03-287$, and the gamma-log signal does not exceed the background level of $200 \mathrm{cps}$. The highest gamma-ray count at $105 \mathrm{ft}$ corresponded to the location of a pale orange fine-grained sandstone, the basal member of a fining-upward sequence, and the gray bleached mudstone that caps the top of the underlying fining-upward sequence. 
The dominant rock types in well 03-288 is grayish-red (10R4/2) mudstone and fine- to coarse-grained pale red $(5 \mathrm{R} 6 / 2 ; 10 \mathrm{R} 6 / 2)$ sandstone. Sandstones in the section are more abundant below, than above, a depth of $100 \mathrm{ft}$. Minor rock types are the pale red (5R6/2;10R6/2) siltstones, which are more common above than below a depth of $100 \mathrm{ft}$. Bedding in the mudstones is massive to convoluted, whereas the sandstones are typically massive. Sandstones commonly are interbedded with thin mudstone layers. The siltstones are mainly massive to laminated. Eight gradational fining-upward sequences were identified in the core. Most begin with basal sandstone, grade upward into siltstone, and are capped by mudstone. Not all of the fining-upward sequences are complete; the basal lithology in the sequence from 61 to $81 \mathrm{ft}$ is siltstone rather than sandstone (pl. 5). The uppermost sandstone (depth of 58 to $61 \mathrm{ft}$ ) is an altered, limonite-stained, fine-grained, micaceous, grayish-orange (10YR7/4) unit. A bleached zone within the altered sandstone is the only visible diagenetic texture.

Postdepositional calcite is present in the matrix as void filling and speckling; calcite speckling, however, is sparse. Clay nodules are scattered throughout the core, but are more common in siltstone and mudstone than in sandstone. Sedimentary structures and trace fossils such as worm burrows and root casts are rare and are present only from 90 to $105 \mathrm{ft}$ in siltstone strata. Limonite is associated with fractures to depths as great as $180 \mathrm{ft}$. Lenses and fragments of organic material are present in the altered sandstone at a depth of $60 \mathrm{ft}$.

A minor zone of anomalously high radioactivity was identified from the gamma log at well 03-288. The highest gamma-ray count (more than $200 \mathrm{cps}$ ) at $165 \mathrm{ft}$ corresponds to a coarsegrained pale red sandstone at the base of a fining-upward sequence. The stratigraphic position of this radioactive zone is similar to that of much more highly radioactive zones in the Stockton Formation.

The fracture-density histogram for well 03-288, beginning at a depth of $55 \mathrm{ft}$ (pl. 6), shows a moderately fractured section from 55 to $80 \mathrm{ft}$ in the transition zone, just below the regolith, that averages eight fractures per 5 - $\mathrm{ft}$ interval. A fissured zone from 56.5 to $57 \mathrm{ft}$ corresponds to a small response on the caliper log. The highly fractured interval from 80 to $85 \mathrm{ft}$ contains 13 fractures. Other highly fractured intervals are present at 110 to $115 \mathrm{ft}$ and 125 to $130 \mathrm{ft}$. In the sections between the highly fractured intervals, the number of fractures per 5-ft interval is less than five. The highly fractured intervals are in mudstone strata. The spontaneous-potential log shows a slight decrease in response with depth, possibly corresponding to decreasing fracture density. (The caliper-log tool used at well 03-288 was less sensitive than the one used at the other wells at this site; even significant fracture zones with assumed enlargements in well diameter were not indicated by a $\log$ response). Low-angle open fractures predominate; high-angle fractures, whether open or sealed, are rare.

The few sealed fractures are cemented with clay and calcite, and, in some parts of core, limonite. Major amounts of limonite were present at 55 to $60 \mathrm{ft}$ and 165 to $180 \mathrm{ft}$. The limonite in the part of the core below $150 \mathrm{ft}$ is present as speckling, which represents pervasive limonitization of the surrounding sandstone and indicates abundant circulation of oxidizing water, but may be a diagenetic feature (limonitization in this zone may have occurred during the consolidation of the rock) (pl. 6). 
Moderate amounts of water were produced from well 03-288. During sampling the well was pumped at a rate of $5 \mathrm{gal} / \mathrm{min}$ with $50 \mathrm{ft}$ of drawdown. During development, a yield of $6 \mathrm{gal} / \mathrm{min}$ was maintained for 2 hours. Yield from this well is lower than that from the other wells at site 6; its position near the ridgetops (rather than near the valley floor) results in much greater depth to water. In addition, the presence of a significant thickness of massive, sparsely fractured sandstone in the strata penetrated by this well may result in reduced yield.

Three wells (3-286, 3-287, and 3-288), which are completed in red mudstone, siltstone, and fine-grained sandstone of the lower part of the Passaic Formation, were sampled at site 6 . The concentration of calcium, the dominant cation, ranged from 79 to $110 \mathrm{mg} / \mathrm{L}$; the concentration of bicarbonate, the dominant anion, ranged from 147 to $239 \mathrm{mg} / \mathrm{L}$ as alkalinity (app. C). Concentrations of sodium and chloride were significant and variable, ranging from 13 to $42 \mathrm{mg} / \mathrm{L}$ and from 37 to $90 \mathrm{mg} / \mathrm{L}$, respectively. Concentrations of magnesium and sulfate were low and varied little, as indicated by the Stiff diagrams (fig. 8). Specific conductance ranged from 529 to $760 \mu \mathrm{S} / \mathrm{cm}$, indicating that the samples contained abundant dissolved mineral matter.

Water from well 03-288, located near the ridgetop, was strongly oxidizing (DO, $6.8 \mathrm{mg} / \mathrm{L}$ ) and water from well 03-286 near the river valley was not oxygenated (DO, $0.7 \mathrm{mg} / \mathrm{L})$. Concentration of dissolved nitrate was greatest $(11 \mathrm{mg} / \mathrm{L})$ in oxidizing water from well 03-288, exceeding the USEPA MCL. Nitrate was present in relatively high concentrations in water from wells 03-286 and 03-287 (4.4 and $4.6 \mathrm{mg} / \mathrm{L}$, respectively); however, ammonia also was detected in water from well $03-286(0.14 \mathrm{mg} / \mathrm{L})$. Concentrations of iron and manganese in the strongly oxidizing water sample from well $03-288$ were low $(7$ and $<1 \mu \mathrm{g} / \mathrm{L}$, respectively).

Concentrations of iron and manganese in the less oxidizing water sample from well 03-287 were 190 and $16 \mu \mathrm{g} / \mathrm{L}$, respectively.

Barium and strontium were detected in the greatest concentrations of the trace elements analyzed for; concentrations ranged from 140 to $230 \mu \mathrm{g} / \mathrm{L}$ and from 130 to $240 \mu \mathrm{g} / \mathrm{L}$, respectively. Concentrations of lithium were low $(8-14 \mu \mathrm{g} / \mathrm{L})$. Other trace elements detected in solution were arsenic, cadmium, and zinc; concentrations of these three constituents were less than or equal to $5 \mu \mathrm{g} / \mathrm{L}$. The slightly alkaline nature of the ground water $(\mathrm{pH} 7.2-7.8)$ could inhibit the solubility of many trace elements. Furthermore, trace-element concentrations in the red mudstone wholerock sample collected from site 5 (app. B-2) were much lower than those in the black mudstones; therefore, we expect that the trace-element concentration of the red mudstones at site 6 are also low.

Samples of water from wells 03-286, 03-287, and 03-288 contained low concentrations of radioactivity, a result that would be expected in the absence of highly radioactive lithology. The maximum gross alpha-particle activity was $7.7 \mathrm{pCi} / \mathrm{L}$ in water from well $03-286$. Concentrations of gross beta-particle activity varied little; the maximum value $(4.6 \mathrm{pCi} / \mathrm{L})$ also was measured in water from well 03-286. Total uranium-isotope activity was low; the maximum value $(5.1 \mathrm{pCi} / \mathrm{L})$ was measured, again, in water from well 03-286. Gross alpha-particle activity was less than $1 \mathrm{pCi} / \mathrm{L}$ in water from well $03-288$, and total uranium-isotope activity was only $0.9 \mathrm{pCi} / \mathrm{L} .{ }^{226} \mathrm{Ra}$ and ${ }^{228} \mathrm{Ra}$ concentrations were below the MRL in water from all three wells, except a measured concentration of $0.21 \mathrm{pCi} / \mathrm{L}$ for radium-226 in well 03-286. Concentrations of dissolved ${ }^{222} \mathrm{Rn}$ were near the median value of $1,420 \mathrm{pCi} / \mathrm{L}$ reported for the Newark Basin by 
Szabo and Zapecza (1987). ${ }^{222} \mathrm{Rn}$ concentrations ranged from $1,300 \mathrm{pCi} / \mathrm{L}$ in water from well $03-288$ to $2,060 \mathrm{pCi} / \mathrm{L}$ in water from well $03-286$. The lowest measured ${ }^{222} \mathrm{Rn}$ concentration at the site was in water from well 03-288 despite the fact that this well intercepted the sandstone strata in which the highest radioactivity at site 6 was measured; this result indicates that circulating water intercepted by the well likely did not come in contact with the radioactive strata. Concentrations of tritium, 59 to $68 \mathrm{pCi} / \mathrm{L}$, indicate that ground water at the site is of recent (post-1960 recharge) origin (Hendry, 1988).

Many volatile organic compounds were detected in water samples collected at the site; these include chloroform, tetrachloroethylene, 1,1-dichloroethane, 1,1,1- trichloroethane, 1,2-dichloropropane, 1,2-transdichloroethane, and trichloroethylene. The concentration of dissolved tetrachloroethylene in the sample from well 03-287 $(1.9 \mu \mathrm{g} / \mathrm{L})$ exceeded the USEPA MCL. Concentrations of dissolved trichloroethylene in the water sample from well 03-287 $(3.9 \mu \mathrm{g} / \mathrm{L})$ and well $03-286(8.3 \mu \mathrm{g} / \mathrm{L})$ also were greater than the USEPA MCL. 